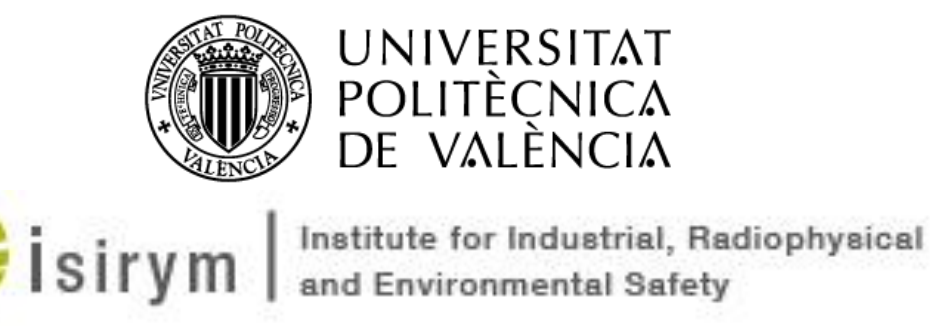

PhD IN INDUSTRIAL ENGINEERING AND PRODUCTION Department of Chemical and Nuclear Engineering

\title{
OPTIMIZATION OF OPERATION PARAMETERSIN ULTRAFILTRATION BY EXPERIMENT DESIGN, MATHEMATICAL MODELING AND FOULING CHARACTERIZATION OF THE MEMBRANES USED TO REMOVE DISSOLVED AND COLLOIDAL SUBSTANCES FROM A TREATED PAPER MILL EFFLUENT.
}

\author{
AUTOR: \\ Mayko Rannany Santos Sousa \\ A thesis submitted for the degree of Doctor of Philosophy \\ of \\ Polytechnic University of Valencia
}

Supervised by Prof. Dr. Jaime Lora García

Co-supervised by Dra. María Fernanda López Pérez

Co-supervised by Dr. Marc HERAN

August 2020

Valencia-Spain 


\section{UNIVERSIDAD POLITÉCNICA DE VALENCIA (UPV)}

A thesis

entitled

Optimization of operation parameters in ultrafiltration by experiment design, mathematical modeling and fouling characterization of the membranes used to remove dissolved and colloidal substances from a treated paper mill effluent.

by

Mayko Rannany Santos Sousa

Submitted to the Doctoral School of the Universitat Politècnica de València (UPV) as partial fulfillment of the requirements for the Doctor of Philosophy Degree in Industrial Engineering and Production

Approved by members of the thesis tribunal:

Dra. Beatriz Miguel Hernández

Cated rática de Universidad

Universidad Politécnica de Cartagena

Dr. Geoffroy LESAGE

Associate Professor in Environmental and Chemical Engineering

University Montpellier-Institut Européen des Membranes

Dra. María Isabel Alcaina Miranda

Cated rática de Universid ad

Universitat Politècnica de València

Date Approved: 2020 


\section{Declaration}

I, Mayko Rannany Santos Sousa, hereby confirm that:

- The material presented in this thesis is my own work;

- I certify that my thesis has been entirely written by me and contains no material previously published by other people except where due acknowledgement and citations has been made within in this document;

- This thesis has also not been submitted previously, in part or in whole, to qualify for any other degree academic award at this university or any other institution.

Signed:

On ,2020 


\section{Acknowledgements}

The fear of the Lord is the beginning of knowledge: but fools despise wisdom and instruction. Proverbs 1:7.

First of all, I would like to thank God for providing me capacity, opportunity, strength, and determination to complete my PhD thesis. I would like to express my sincere gratitude to my supervisor Professor Dr. Jaime Lora Garcia, for your strong support, guidance and encouragement during my $\mathrm{PhD}$ research project. This thesis would be very difficult without your support.

I would also like to thank my co-supervisor Professor Dra. Maria Fernada Lopez, for her fundamental direction, assistance, constructive comment and guidance th roughout the project.

Special appreciation is given to Professor Dr. Marc Heran for allowed my access to the European Membrane Institute, his exceptional insights and brilliant ideas into membrane engineering have immensely helped me to enrich my knowledge in this field. I'm feel honored to have this opportunity to work with Marc and his team (Membrane Engineering Department).

My deepest and special gratitude to my parents, Suelda Sousa Santos and Francisco Carlos Salazar who sacrificed a lot in their life for my brothers and me. I could not be in this stage of my life withouttheir never-ending supportand encouragement. Besides my gratitude goes to my family in Brazil (especially to my aunt Simone) for their continuous support, lives and love during my stay abroad.

I wish to gratefully acknowledge UPV through its research program and the EuroBrazilian Windows + project (with financial support granted by the European Commission through the Erasmus Mundus Programme).

Special thanks to our lab manager at UPV Antonia Valor for her help throughout the thesis. Last but no least, I would like say thanks all my friends in Alcoy - Spain and Montpellier - France specially in the European Membrane Institute and UPV-EPSA who shared their time, experience and lives with me. Without their company would have a much more difficult time in this Journey far my country and family. 


\section{List of Publications}

During the development of this Doctoral Thesis, the results obtained have been divulged in several international publications, such as journals, congress and conferences.

Journal articles forming chapters of the thesis

1. Mayko Rannany S. Sousa; Jaime Lora - Garcia; Maria-Fernanda López-Pérez. Modelling approach to an ultrafiltration process for the removal of dissolved and colloidal substances from treated wastewater for reuse in recycled paper manufacturing. Journal of Water Process Engineering, Volume 21, February (2018), 96-106; doi.org/10.1016/j.jwpe.2017.11.017.

2. Mayko Rannany S. Sousa; Lora-García, J.; López-Pérez, M.-F.; Heran, M. Identification of Foulants on Polyethersulfone Membranes Used to Remove Colloids and Dissolved Matter from Paper Mill Treated Effluent. Journal Water 2020, 12, 365; DOI : 10.3390/w12020365.

3. Mayko Rannany S. Sousa; Jaime Lora-Garcia; Maria-Fernanda López-Pérez, Asunción Santafé-Moros. Operating conditions optimization via the taguchi method to remove colloidal substances from recycled paper and cardboard production wastewater. Journal Membranes 2020, 10(8), 170 (Section: Membrane Engineering and Applications). DOI.org/10.3390/membranes 10080170

Additional publications relevant to the thesis but not included as chapters

1. Mayko Rannany S.Sousa; JaimeLora-Garcia; Maria-FernandaLópez-Pérez. Experimental study and modeling of forward osmosis process for activated sludge concentration by using residual brine from a stuffed olive factory as draw solution. Journal of Water Process Engineering, Volume 21, February 2018, Pages 143-153. 
Presentations in international conferences

1. Sousa, M.R.S; A.Valor ; J.Lora -Garcia ; Maria-Fernanda López-Péres. Parámetros de diseño para el escalado de una planta de Osmosis Directa para la concentración de lodos activos procedentes de una EDAR. XI Congreso Internacional de Aedyr -Valencia, España, 19-21 Octubre, 2016 REF: VAL-411/16.

2. M.R. Santos Sousa; J. Lora-Garcia; M. López-Péres. Modelling approach of ultrafiltration process for the removal of suspended solids and colloids from recycled paper wastewater. 3rd International Conference on Desalination using Membrane Technology - 2-5 abril 2017. Las Palmas, Gran Canaria, Spain

3. M.R. Santos Sousa; J. Lora-Garcia; M. López-Péres. Modelling forward osmosis process for activated sludge concentration by using a residual brine from stuffed olive industry as draw solution. 3rd International Conference on Desalination using Membrane Technology -2-5 abril 2017. Las Palmas, Gran Canaria, Spain

4. Jaime Lora-Garcia; Mayko Rannany S. Sousa; Maria-Fernanda López-Pérez; M. Arteaga; E.S. Oporto; N.I. Pinaya. Design and modelling forward osmosis process for the recovery and reuse of chromium from chrome tanning wastewater. Euromembrane 2018 conference, , 9-13.July 2018, Valencia Spain.

5. M. R. S. Sousa, J. Lora-Garcia, M.F. López-Pérez. Optimization of operating conditions in ultrafiltration process for the elimination of organic matter in the paper industry waste effluent: Taguchi experimental design approach. Euromembrane 2018 conference, , 9-13.July 2018, Valencia Spain.

6. Mayko Rannany S. Sousa; Jaime Lora-Garcia; Maria-Fernanda López-Pérez; Geoffroy Lesage, Marc Heran. Study of organic foulants in membranes fouled by paper mill effluent based on Three-Dimensional Fluorescence Spectra 3DEEM. 16t ${ }^{\text {h }}$ NYM 2018 conference July 5-7 Valencia. 
Several conventional treatment methods have been used to treat the wastewater from different paper mills. Previous studies and applications have shown that conventional methods are not capable to comply with the most stringent environmental regulations on effluent quality and/or for the process water to be reused in papermaking (Shankar et al., 2014).

Faced with the necessity for process optimization membrane separation technology has attracted more and more attention as an alternative way to treat paper mill wastewater. Some nanofiltration (NF), ultrafiltration (UF) and reverse osmosis (RO) plants have been installed in pulp and paper mills to purify secondary and tertiary effluents using external biological treatment. The major advantage of the membrane separation technology is that it can save energy, reduce the carbon footprint and simplify operation. Many reports have demonstrated the applicability of membrane technology to pulp and paper mill wastewater (Pokhrel and Viraraghavan, 2004a). Additionally, UF can be used as an advanced tertiary treatment to remove suspended solids and dissolved and colloidal substances (DCS) during the treatment of paper industry effluent.

However, membrane fouling is a major drawback that limits widespread and full-scale applications of UF and, currently, this treatment technology can only be used to filter paper mill effluent that has been pre-treated and meets discharge standards (Puro et al., 2011a). To help minimize membrane fouling, itis important to understand the effect of operating conditions on process and investigation the chemical composition and possible origins of membrane foulants.

The overall goal of this research has been divided into three main parts: $i)$ describes how to find optimal operating conditions of four controlling parameters, such as transmembrane pressure (TMP), cross-flow velocity (CFV), temperature and molecular weight cut-off (MWCO) for maximizing the average permeate flux $\left(\bar{J}_{P}\right)$ and chemical oxygen demand (COD) rejection, and minimizing the cumulative flux decline (SFD) using Taguchi method and utility concept for a cross-flow UF in pilot scale, used to remove DCS from a paper mill treated effluent (PMTE), ii) flux decline and fouling mechanisms of UF membranes fouled with PMTE were examined by theoretical 
modelling. The results from UF tests were expressed in terms of permeate flux (Jp) as a function of time to check modified Hermia's models adapted to crossflow filtration and cake formation in constant-pressure filtration, and iii) describes the Identification, characterization and possible origins of UF membrane foulants. Techniques such as chemical analysis, FESEM, SEM-EDS, ATR-FTIR and 3DEEM analysis were applied to understand which fraction of the foulants caused the fouling.

This research found that the TMP and MWCO have the greatest contribution to the average permeate flux and SFD. In the case of the COD rejection rate, the results showed that MWCO has the highest contribution followed by CFV. The optimum conditions were found to be the second level of TMP (2.0 bar), the third level of the CFV $(1.041 \mathrm{~m} / \mathrm{s})$, the second level of the temperature $\left(15^{\circ} \mathrm{C}\right)$, and the third level of MWCO $(100 \mathrm{kDa})$. Under these optimum conditions $\bar{J}_{P}$, COD rejection and SFD resistance of $81.15 \mathrm{~L} / \mathrm{m}^{2} / \mathrm{h}, 43.90 \%$ and 6.01 (around $28.96 \%$ of $\overline{F D}$ ), respectively, were obtained and they were within of the predicted range at the $95 \%$ confidence interval.

Furthermore, the results showed that the predictions of the modified Hermia's models adapted to cross-flow UF had good agreements with experimental data, under different conditions tested for PMTE. Therefore, it can be concluded that for all cases the best fit (higher accuracy) to the experimental data corresponds to the complete (coefficient of determination $\left.R^{2}>0.97\right)$ and intermediate $\left(R^{2}>0.96\right)$ blocking, followed by the cake layer formation $\left(R^{2}>0.94\right)$. Moreover, measurements of particle size distribution and zeta potential near the isoelectric point, showed a substantial reduction in colloidal compounds.

The 3DEEM analysis revealed that the majority of the organic foulants with fluorescence characteristics on the fouled membranes were colloidal proteins (proteinlike substances I+II) and macromolecular proteins (SMP-like substances). Further, polysaccharide (cellulosic specie), fatty and resin acid substances were identified on the fouled membrane by the ATR-FTIR analysis and they play an important role in membrane fouling. In addition, the membrane SEM-EDS analysis showed accumulate and adsorbed onto the membrane surfaces of inorganic foulants, such as multivalent metal ions and especially $\mathrm{Ca}^{2+}$ (acts as a binding agent) that could accelerate cake layer formation on the membrane. 


\section{Resumen}

Varios métodos de tratamiento convencionales han sido usados para depuración de las aguas residuales de diferentes procesos de fábricas de celulosa y papel. No obstante, previos estudios y aplicaciones han demostrado que los métodos convencionales no son en su totalidad capaces de cumplir con las normativas medioambientales que se hacen cada día más estrictas con respecto a la calidad de los efluentes y / o para que el agua se reutilice en el proceso (Shankar et al., 2014).

Ante la necesidad de optimizar tal proceso, la tecnología de separación mediante membranas ha atraído cada vez más atención como una forma alternativa y eficaz de tratar las aguas residuales de las fábricas de papel. Algunas plantas de nan ofiltración (NF), ultrafiltración (UF) y ósmosis inversa (RO) se han instalado en la industria papelera como tratamiento terciario a fin aumentar la calidad del efluente a verter o reutilizar. Entre las principales ventajas de la tecnología de separación por membranas se encuentran: bajo requerimiento energético, operación simplificada, reducción de la huella de carbono y pueden combinarse fácilmente con otros procesos de separación. Muchos informes científicos han demostrado la aplicabilidad de la tecnología por membrana a las aguas residuales de las fábricas de celulosa y papel (Pokhrel and Viraraghavan, 2004a). Además, la UF puede ser utilizada como un tratamiento terciario avanzado para eliminar sólidos suspendidos $y$, sustancias disueltas y coloidales (DCS) durante el tratamiento de efluentes de la industria papelera.

Sin embargo, el ensuciamiento de las membranas es un inconveniente importante que limita las aplicaciones de UF a gran escala, y en la actualidad esta tecnología de tratamiento solo se puede utilizar para filtrar efluentes de la industria papelera pretratados y que cumplan con los estándares de descarga (Puro et al., 2011b). Por lo tanto, a fin de minimizar el fenómeno de ensuciamiento de las membranas, es importante comprender el efecto de las condiciones de operación, de los mecanismos de ensuciamiento e investigar la composición química de sustancias contaminantes de las membranas.

El objetivo general de esta investigación se dividió en tres partes principales: i) describe cómo encontrar las condiciones óptimas de operación de cuatro parámetros de proceso: presión transmembrana (TMP), velocidad de flujo cruzado (CFV), temperatura y corte de peso molecular (MWCO) para maximizar el flujo promedio de permeado $\left(\bar{J}_{P}\right)$ y rechazo de la demanda química de oxígeno (COD) y minimizar el 
descenso del flujo de permeado acumulado (SFD) utilizando el método de Taguchi (Design Robusto) y utility concept aplicado a un proceso de UF a flujo cruzado en escala piloto, para remover DCS de efluentes tratados de la industria papelera (PMTE), ii) el descenso del flujo de permeado y los mecanismos de ensuciamiento (fouling) de las membranas de UF ensuciadas con PMTE se examinaron mediante modelos matemáticos semi-empíricos. Los resultados para los diferentes ensayos de UF se expresaron en términos de variación del flujo de permeado (Jp) en función del tiempo para verificar la precisión del ajuste (mayor valor de $R^{2}$ y menor valor de desviación estándar) de los distintos modelos de Hermia adaptados a flujo tangencial y del modelo de formación de torta en filtración a presión constante ajustados a los datos experimentales, y iii) describe métodos de identificación, caracterización y posibles orígenes de las sustancias contaminantes (foulants) en las membranas de UF. Técnicas como el análisis físico-química, FESEM, SEM-EDS, ATR-FTIR y 3DEEM se llevaron a cabo para comprender qué fracción de los contaminantes son responsables por la formación de incrustaciones sobre la superficie y adsorción dentro de los poros de las membranas.

Los resultados obtenidos durante la etapa de optimización de parámetros del procesos demostraron que TMP y MWCO tienen la mayor contribución en el $\bar{J}_{P}$ y SFD. En el caso de la tasa de rechazo de COD, los resultados mostraron que MWCO tiene la mayor contribución seguida de CFV. Por consiguiente, las condiciones óptimas se encontraron para el segundo nivel de TMP (2.0 bar), el tercer nivel del CFV $(1.041 \mathrm{~m}$ / s), el segundo nivel de la temperatura $\left(15^{\circ} \mathrm{C}\right)$ y el tercer nivel de MWCO $(100 \mathrm{kDa})$. Bajo estas condiciones óptimas de operación $\bar{J}_{P}$, rechazo de COD y SFD alcanzaron respuestas de $81.15 \mathrm{~L} / \mathrm{m} 2 . \mathrm{h}, 43.90 \%$ y 6.01 (alrededor de $28.96 \%$ para $\overline{F D}$ ), respectivamente, valores dentro del rango previsto del intervalo de confianza del $95 \%$. Además, los modelos de Hermia adaptados a UF en flujo tangencial fueron capaces de predecir con gran precisión el descenso del Jp y los mecanismos de ensuciamiento en función del tiempo para todas las membranas seleccionadas (10,30 y $100 \mathrm{kDa}$ ) y bajo diferentes condiciones ensayadas de UF. Por lo tanto, los modelos que presentan un mayor grado de ajuste son el bloqueo completo de poros (coeficiente de determinación $\left.R^{2}>0.97\right)$ y bloqueo intermedio $\left(R^{2}>0.96\right)$, seguido por el modelo de formación de torta $\left(R^{2}>0.94\right)$, lo que indica que estés son los principales mecanismos de ensuciamiento de las membranas. Vale la pena mencionar que mediciones de la 
distribución del tamaño de partícula y potencial zeta (cerca del punto isoeléctrico), confirman una reducción sustancial en los compuestos coloidales.

Análisis de 3DEEM revelaron que la mayoría de la materia orgánica fluorescentes en las membranas sucias eran proteínas coloidales (componentes similares a proteínas I + II) y proteínas macromoleculares (componentes similares a SMP). Además, polisacáridos (especie celulósica) y sustancias como ácidos grasos y resinosos fueron identificadas en las membranas contaminadas mediante análisis ATR-FTIR, tales sustancias desempeñan un papel importante en el ensuciamiento de las membranas. Por fin, análisis SEM-EDS para las membranas ensuciadas con PMTE se detectó concentración de contaminantes inorgánicos (iones metálicos multivalentes) especialmente el $\mathrm{Ca}^{2+}$ que podría acelerar la formación torta en la superficie de la membrana. 


\section{Resum}

Diversos mètodes de tractament convencionals han sigutusats per a depuració de les aigües residuals de diferents processos de fàbriques de cel.lu losa i paper. No obstant això, previs estudis i aplicacions han demostrat que els mètodes convencionals no són íntegrament capaços de complir amb les normatives mediambientals, que es fan cada dia més estrictes respecte a la qualitat dels efluents i / o perquè l'aigua es reutilitze en el procés (Shankar et al., 2014).

Davant la necessitat d'optimitzar tal procés, la tecnologia de separació mitjançant membranes ha atret cada vegada més atenció com una forma alternativa i eficaç de tractar les aigües residuals de les fàbriques de paper.

Algunes plantes de nanofiltració (NF), ultrafiltració (UF) i osmosi inversa (RO) s'han instal-lat en la indústria paperera com a tractament terciari a fi augmentar la qualitat de l'efluent a abocar o reutilitzar. Entre els principals avantatges de la tecnologia de separació per membranes es troben: baix requeriment energètic, operació simplificada, reducció de la petjada de carboni i poden combinar-se fàcilment amb altres processos de separació.

Molts informes científics han demostrat l'aplicabilitat de la tecnologia per membrana a les aigües residuals de les fàbriques de cel-lu losa i paper (Pokhrel and Viraraghavan, 2004a). A més, la UF pot ser utilitzada com un tractament terciari avançat per a eliminar sòlids suspesos $i$, substàncies dissoltes i col-loidals (DCS) durant el tractament d'efluents de la indústria paperera.

No obstant això, el embrutiment de les membranes és un inconvenient important que limita les aplicacions de UF a gran escala, i en l'actualitat aquesta tecnologia de tractament sol es pot utilitzar per a filtrar efluents de la indústria paperera pre-tractats i que complisquen amb els estàndards de descàrrega (Puro et al., 2011b). Per tant, a fi de minimitzar el fenomen de embrutiment de les membranes, és important comprendre l'efecte de les condicions d'operació, dels mecanismes de embrutiment $\mathrm{i}$ investigar la composició química de substàncies contaminants de les membranes.

L'objectiu general d'aquesta investigació es va dividir en tres parts principals: $i$ ) descriu com trobar les condicions òptimes d'operació de quatre paràmetres de procés: pressió transmembrana (TMP), velocitat de flux creuat (CFV), temperatura i tall de pes molecular (MWCO) per a maximitzar el flux mitjà de permeat $\left(\bar{J}_{P}\right)$ i rebuig de la 
demanda química d'oxigen (COD) i minimitzar el descens del flux de permeado acumulat(SFD) utilitzantel mètode de Taguchi (Design Robust) i utility concept aplicat a un procés de UF a flux creuat en escala pilot, per a remoure DCS d'efluents tractats de la indústria paperera (PMTE), ii) el descens del flux de permeat i els mecanismes de embrutiment (fouling) de les membranes de UF embrutades amb PMTE es van examinar mitjançant models matemàtics semi-empírics. Els resultats per als diferents assajos de UF es van expressar en termes de variació del flux de permeat (Jp) en funció del temps per a verificar la precisió de l'ajust (major valor de $\mathrm{R}^{2}$ i menor valor de desviació estàndard) dels diferents models de Hermia adaptats a flux tangencial i del model de formació de coca en filtració a pressió constant ajustats a les dades experimentals, i iii) descriu mètodes d'identificació, caracterització i possibles orígens de les substàncies contaminants (foulants) en les membranes de UF. Tècniqu es com I'anàlisi física-química, FESEM, SEM-EDS, ATR-FTIR i 3DEEM es van dur a terme per a comprendre quina fracció dels contaminants són responsables per la formació d'incrustacions sobre la superfície i adsorció dins dels porus de les membranes.

Els resultats obtinguts durant l'etapa d'optimització de paràmetres del processos van demostrar que TMP i MWCO tenen la major contribució en el $\bar{J}_{P}$ i SFD. En el cas de la taxa de rebuig de $\mathrm{COD}$, els resultats van mostrar que *MWCO té la major contribució seguida de CFV. Per consegüent, les condicions òptimes es van trobar per al segon nivell de TMP (2.0 bar), el tercer nivell del CFV $(1.041 \mathrm{~m} / \mathrm{s})$, el segon nivell de la temperatura $\left(15^{\circ} \mathrm{C}\right)$ i el tercer nivell de MWCO $(100 \mathrm{kDa})$. Sota aquestes condicions òptimes d'operació $\bar{J}_{P}$, rebuig de COD i SFD van aconseguir respostes de 81.15 $\mathrm{L} / \mathrm{m}^{2}$.h, $43.90 \%$ i 6.01 (al voltant de $28.96 \%$ per a $\overline{F D}$ ), respectivament, valors dins del rang previst de l'interval de confiança del $95 \%$.

A més, els models de Hermia adaptats a UF en flux tangencial van ser capaços de predir amb gran precisió el descens del Jp i els mecanismes de embrutiment en funció del temps per a totes les membranes seleccionades $(10,30$ i $100 \mathrm{kDa}$ ) i baix diferents condicions assajades de UF. Per tant, els models que presenten un major grau d'ajust són el bloqueig complet de porus (coeficient de determinació $R^{2}>0.97$ ) i bloqueig intermedi $\left(R^{2}>0.96\right)$, seguit pel model de formació de coca $\left(R^{2}>0.94\right)$, la qual cosa indica que estigues són els principals mecanismes de embrutiment de les membranes. Val la pena esmentar que mesuraments de la distribució de la grandària de partícula i 
potencial zeta (prop del punt isoelèctric), confirmen una reducció substancial en els compostos col-loidals.

Anàlisi de 3DEEM van revelar que la majoria de la matèria orgànica fluorescents en les membranes brutes eren proteïnes col-loidals (components similars a proteïnes I+ II) i proteïnes macromoleculars (components similars a SMP). A més, polisacàrids (espècie cel-lulòsica) i substàncies com a àcids grassos i resinosos van ser identificades en les membranes contaminades mitjançant anàlisis ATR-FTIR, tals substàncies exerceixen un paper important en el embrutiment de les membranes. Per fi, anàlisi SEM-EDS per a les membranes embrutades amb PMTE es va detectar concentració de contaminants inorgànics (ions metàl-lics multivalents) especialment el $\mathrm{Ca}^{2+}$ que podria accelerar la formació coca en la àrea de la membrana. 


\section{Abbreviations}

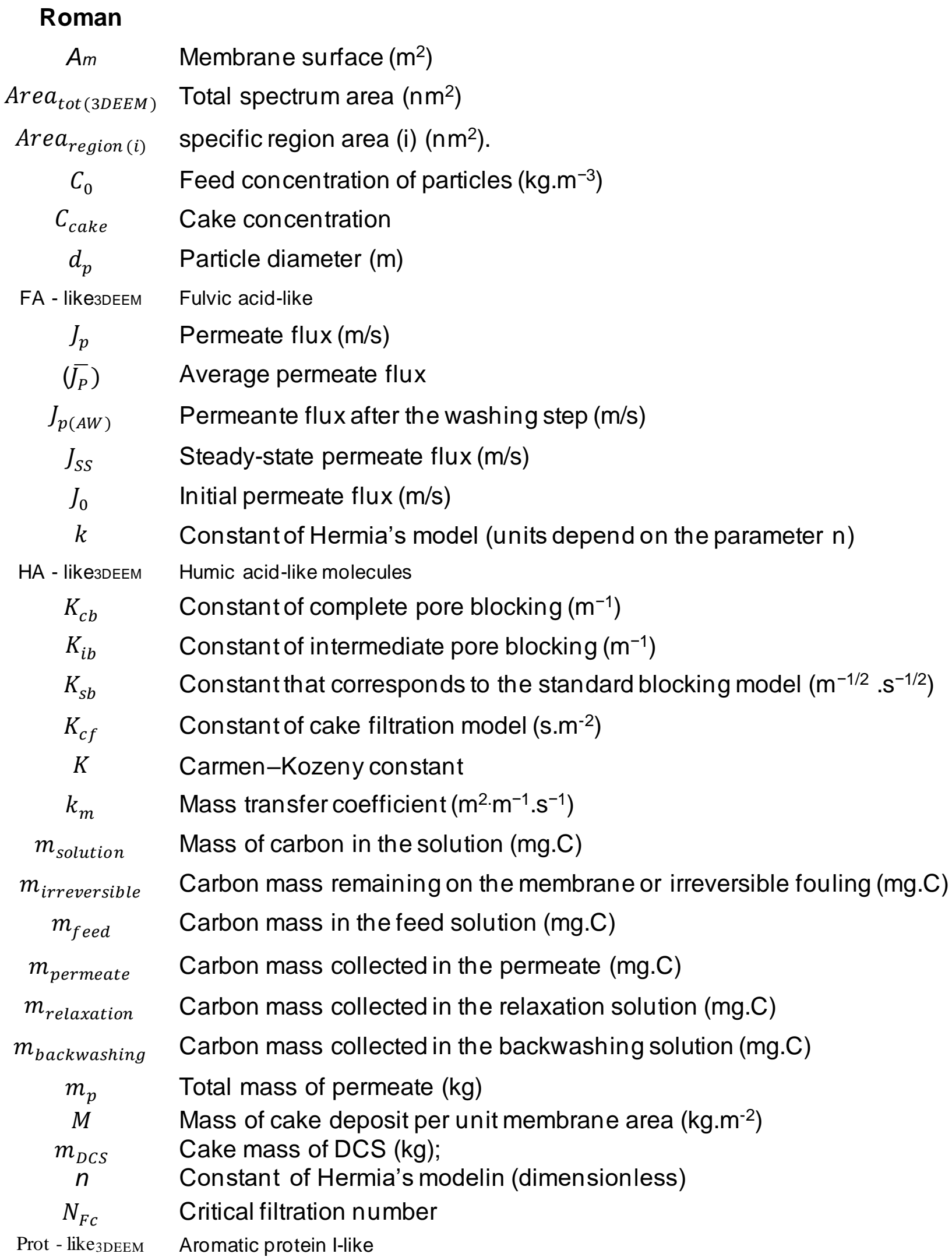




\begin{tabular}{|c|c|}
\hline$\Delta P$ & Hydraulic pressure differential $(\mathrm{Pa})$ \\
\hline$\Delta P_{c}$ & Pressure drop across the concentration polarization layer $(\mathrm{Pa})$ \\
\hline$R_{m}$ & Membrane resistance $\left(\mathrm{m}^{-1}\right)$ \\
\hline$R_{a d}$ & Rresistance due to adsorption \\
\hline$R_{b}$ & Resistance of the blocked membrane $\left(\mathrm{m}^{-1}\right)$ \\
\hline$R_{c}$ & Cake resistance $\left(\mathrm{m}^{-1}\right)$ \\
\hline$R_{p}$ & Concentration polarization resistance $\left(\mathrm{m}^{-1}\right)$ \\
\hline$R_{t}$ & Total resistance $\left(\mathrm{m}^{-1}\right)$ \\
\hline$R_{f}$ & Fouling resistance $\left(\mathrm{m}^{-1}\right)$. \\
\hline$R_{\text {res }}$ & Resistance reversible fouling $\left(\mathrm{m}^{-1}\right)$ \\
\hline$R_{i r r}$ & Resistance irreversible fouling $\left(\mathrm{m}^{-1}\right)$ \\
\hline$r_{c}$ & Specific resistance of the cake layer $\left(\mathrm{m}^{-2}\right)$ \\
\hline$R(\%)$ & Efficiency in removing organic matter \\
\hline$S_{c}$ & Cross sectional area of membrane $\left(\mathrm{m}^{2}\right)$ \\
\hline SMP - likeзDEEM & Soluble microbial product \\
\hline$T$ & Temperature $\left({ }^{\circ} \mathrm{C}\right)$ and $(\mathrm{K})$ \\
\hline$t$ & Filtration time (s) \\
\hline $\mathrm{U}_{\mathrm{i}}\left(\mathrm{x}_{\mathrm{i}}\right)$ & Utility index of $i^{\text {th }}$ response. \\
\hline$V_{\text {solution }}$ & Volume of the solution (L) \\
\hline$V_{p}$ & Permeate volume $\left(\mathrm{m}^{3}\right)$. \\
\hline $\mathrm{W}_{\mathrm{i}}$ & Weight assigned to the $i^{\text {th }}$ response characteristic \\
\hline$Y_{\text {opt }}$ & Predicted optimum conditions \\
\hline \multicolumn{2}{|l|}{ Greek } \\
\hline$\alpha$ & Specific cake resistance $\left(\mathrm{m} \cdot \mathrm{kg}^{-1}\right)$ \\
\hline$\rho$ & Volumetric density $\left(\mathrm{kg} . \mathrm{M}^{-3}\right)$; \\
\hline$\phi$ & Particle volume fraction \\
\hline$\delta$ & Cake thickness (m) \\
\hline$\varepsilon$ & Porosity of membrane \\
\hline$\varepsilon_{0}$ & Porosity of clean membrane; \\
\hline$\varepsilon_{\text {cake }}$ & Cake porosity (dimensionless) \\
\hline$\Delta P$ & Pressure drop (Pa) \\
\hline$\sigma$ & Blocked surface area per unit volu me of permeate $\left(\mathrm{m}^{-1}\right)$ \\
\hline$\tau$ & Tortuosity of membrane \\
\hline$\mu$ & Permeate viscosity (Pa.s) \\
\hline$k_{m}$ & Membrane permeability \\
\hline
\end{tabular}




$\begin{array}{cl}k_{\text {cake }} & \text { Cake permeability } \\ n_{e f f} & \text { Effective sample size } \\ \lambda_{e x} & \text { Excitation wavelength } \\ \lambda_{e m} & \text { Emission wavelength } \\ \Phi(i) & \text { Volume of fluorescence (R.U.nm²) } \\ I_{\text {final }} & \text { Final fluorescence intensity (R.U) }\end{array}$

\section{Acronyms}

\begin{tabular}{cl} 
ANOVA & Analysis of variance \\
AHP & Analytic Hierarchy Process \\
ATR-FTIR & Attenuated total reflection-Fourier transform infrared \\
C & Colloids or colloid fraction \\
CFV & Cross-flow velocity $\left(\mathrm{m} \mathrm{s}^{-1}\right)$ \\
COD & Chemical oxygen demand \\
CFF & Cross-flow filtration \\
CS & Colloidal substances \\
ClCE & Confirmation experiments \\
DCS & Dissolved and colloidal substances \\
DOE & Design of experiments \\
EDS & Energy dispersive spectrophotometry \\
EEM & Excitation-emission matrix \\
eDNA & Extracellular DNA \\
$F D$ & Average flux decline index \\
FESEM & Emission Scanning Electron Microscope \\
FRI & Fluorescence Regional Integration \\
ISIRYM & Institute for Industrial, Radiophysical and Environmental Safety \\
IEM & Institut Européen des Membranes \\
MWCO & Molecularweight cut-off \\
MBRs & Membrane bioreactors \\
$M S_{e}$ & Error variance \\
$M F(i)$ & Area multiplication factor; \\
OCT & Optical coherence tomography \\
OA & Orthogonal arrays \\
PES & Polyethersulfone \\
PMTE & Paper mill treated effluent \\
PARAFAC & Parallel factor analysis \\
SUVA254 & Specific UV absorbance at $254 \mathrm{~nm} \mathrm{(L/mg/m)}$ \\
& \\
\hline
\end{tabular}




$\begin{array}{cl}\text { VFA } & \text { Volatile fatty acids } \\ \text { SEM } & \text { Scanning electron microscopy } \\ \text { SFD } & \text { Cumulative flux decline } \\ \text { S/N } & \text { Signal-to-noise } \\ \text { TMP } & \text { Transmembrane pressure } \\ \text { TOC } & \text { Total organic } \\ \text { TFF } & \text { Tangential flow filtration } \\ \text { UF } & \text { Ultrafiltration } \\ \text { WWTP } & \text { Wastewater treatment plant } \\ \text { 3DEEM } & \text { Three-dimensional excitation emission matrix }\end{array}$


CONTENTS 


\section{Table of Contents}

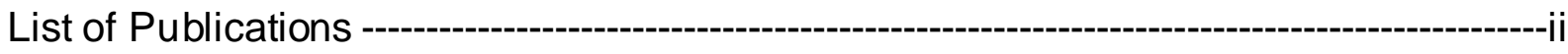

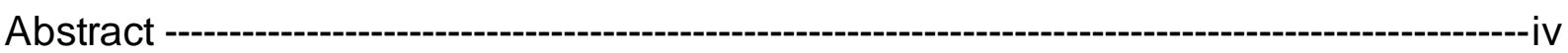

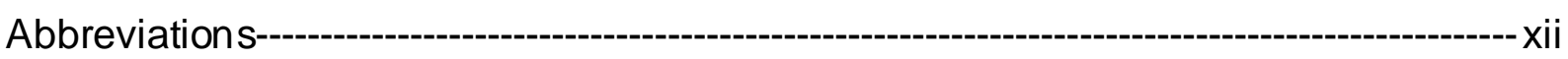

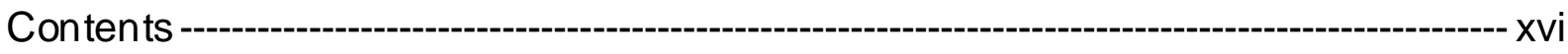

1 CHAPTER: INTRODUCTION............................................................................2

1.1 Background of the project----

1.2 Motivation for work --- 8

1.3 Goal and research objectives------------------------------------------------------------- 9

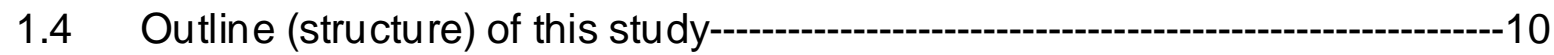

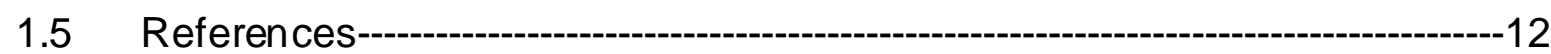

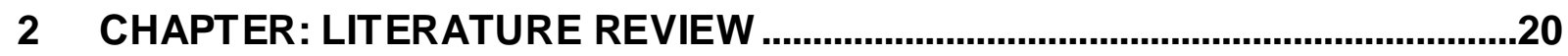

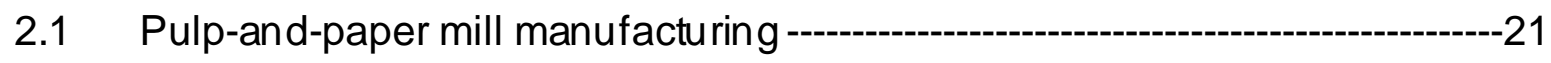

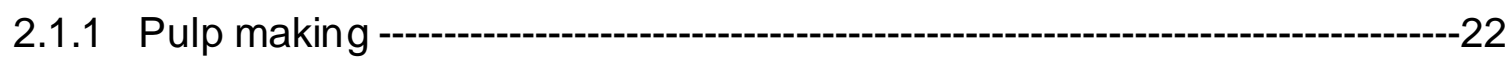

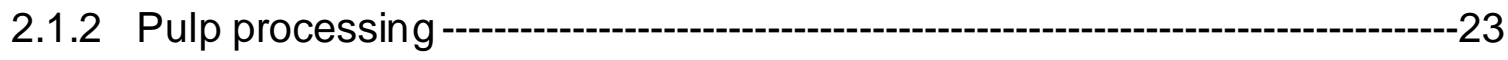

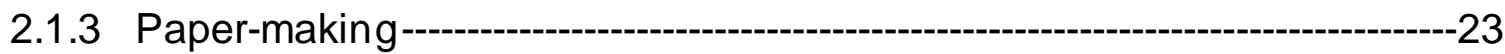

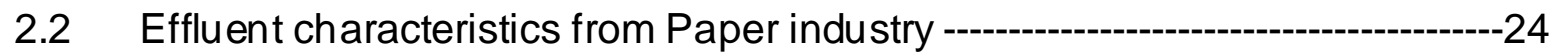

2.3 Wastewater treatment in paper industry ------------------------------------------------25

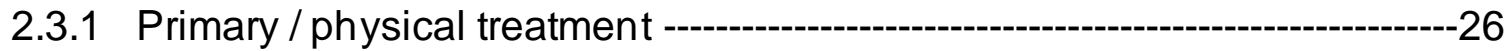

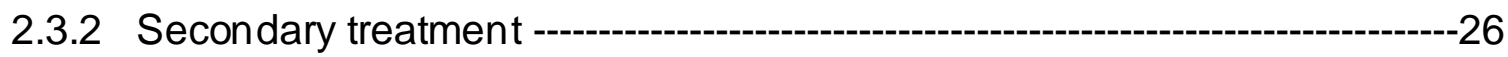

2.3.2.1 Aerobic Treatment----------------------------------------------------------------27

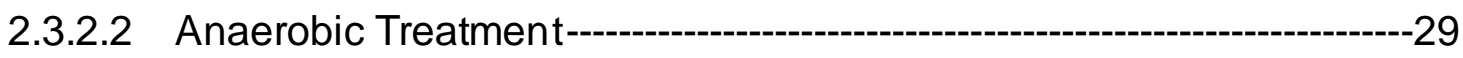

2.3.3 Tertiary treatment----------------------------------------------------------------------------32

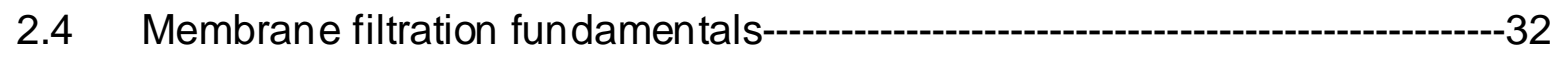

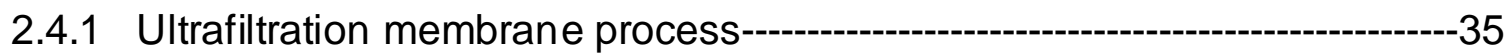

2.4.2 Comparison between Dead - end vs. cross-flow Ultrafiltration---------------37

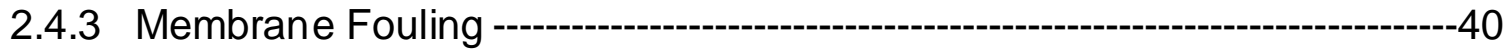

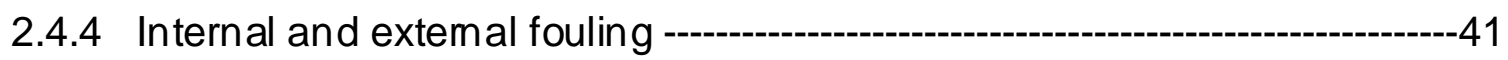

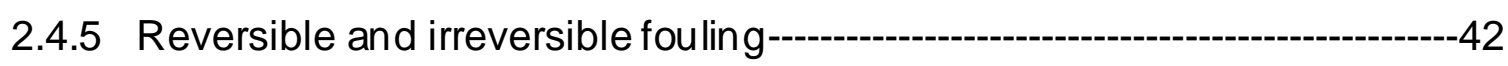

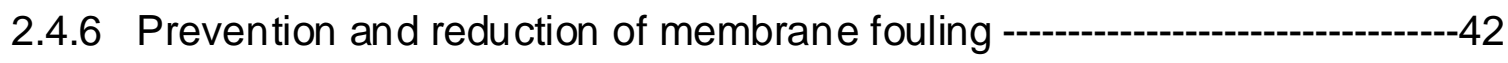


2.5 Mathematical models for membrane fouling analysis ---

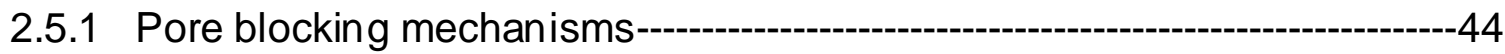

2.5.1.1 Pore blocking models for dead-end filtration---

2.5.1.2 Pore blocking models adapted for cross-flow filtration-------------------48

2.5.2 Resistance-in-series model ---

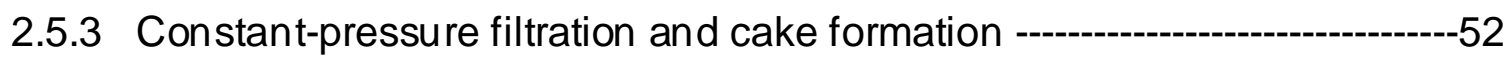

2.6 Membrane foulants characterization and identification ---

2.6.1 Mainly membrane foulants components ----------

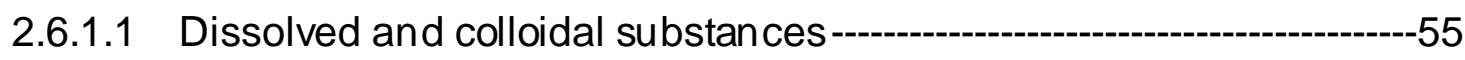

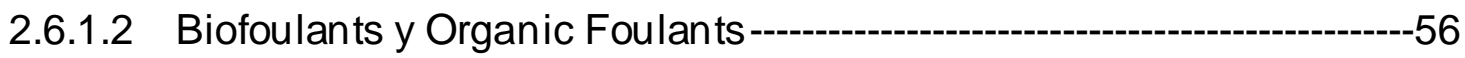

2.6.1.3 Inorganic Foulants ---

2.6.2 Specific ultraviolet absorbance (SUVA)---_-

2.6.3 Fluorescence spectroscopy ---

2.6.4 Attenuated total reflection-Fourier transform infrared (ATR-FTIR) ----------62

2.6.5 Scanning electron microscopy (FESEM) ---

2.6.5.1 SEM-energy-dispersive spectrophotometry (EDX) ---

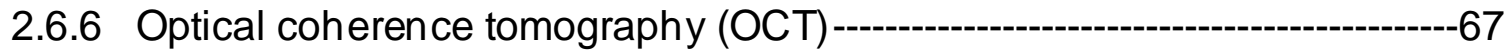

2.7 References-----on

3 CHAPTER: GENERAL MATERIALS AND METHODS ........................................

3.1 Source and properties of treated effluent used as feed solution in the UF

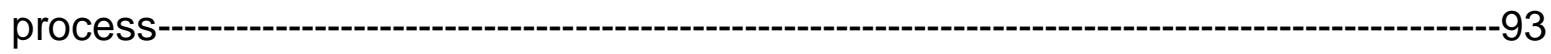

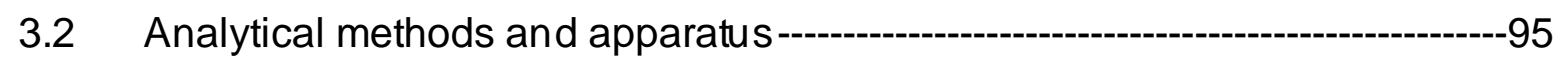

3.2.1 General characteristics -

3.3 Membrane properties and characteristics ---on

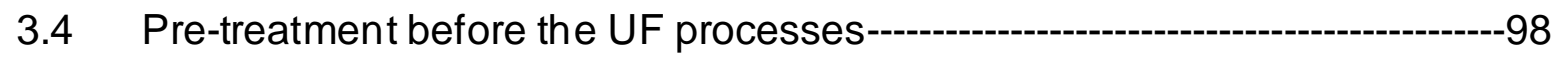

3.5 Cross-flow filtration experiments---

3.5.1 Cross-flow filtration setup----_-

3.5.2 Membrane characterisation ---

3.5.3 Flux decline in UF ---

3.5.4 Cleaning membranes procedure ---_-

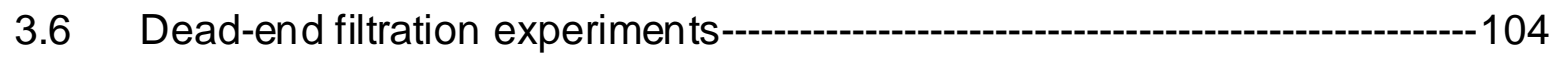

3.6.1 Dead-end filtration setup ---o- 
3.6.2 Filtration experiments 106

3.7 References 106

4 CHAPTER: PROCESS OPTIMIZATION VIA TAGUCHI METHOD TO REMOVE COLLOIDAL SUBSTANCES FROM RECYCLED PAPER AND CARDBOARD PRODUCTION WASTEWATER

4.1 Abstract 110

4.2 Introduction 111

4.3 Materials and methods---113

4.3.1 Paper mill treated effluent feedstock ---

4.3.2 Membranes and experimental setup----_-

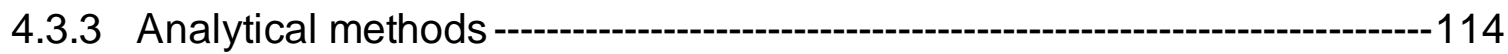

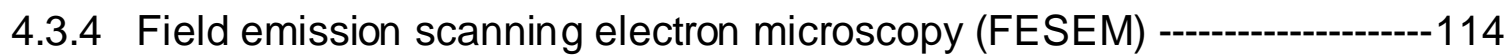

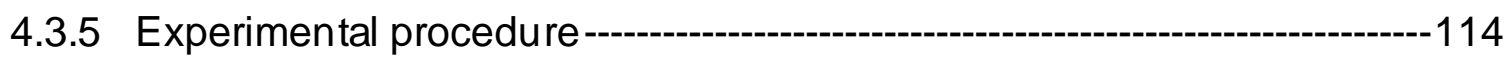

4.3.5.1 Ultrafiltration experiments ---114

4.3.5.2 Average permeate flux, COD rejection and cumulative flux decline analysis 115

4.3.6 Experimental design based on the Taguchi method---------------------116

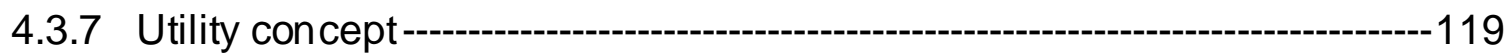

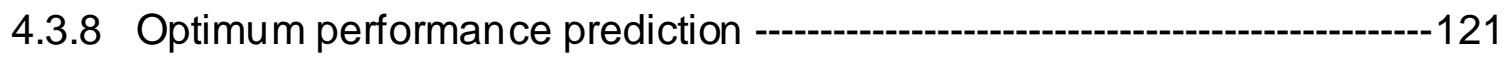

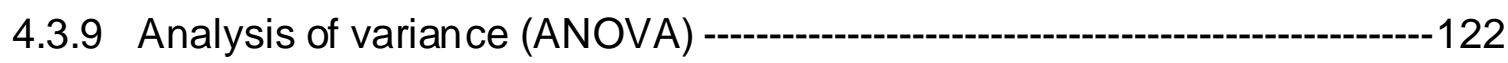

4.4 Results and discussion --- 123

4.4.1 Design of experiments and experimental results ----_-

4.4.2 Taguchi results ----o-_-127

4.4.3 ANOVA results ---_- 131

4.4.4 Optimum results obtained from the Taguchi method and utility concept134

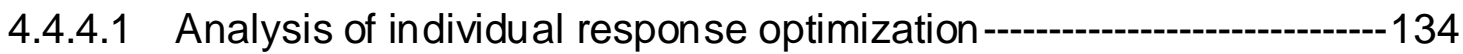

4.4.4.2 Analysis of multi- response optimization ---

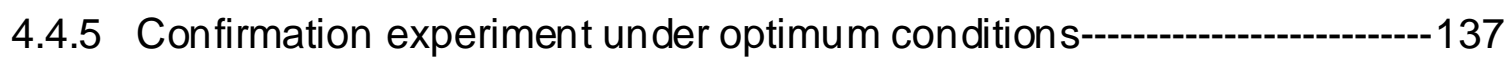

4.5 Conclusion -- 141

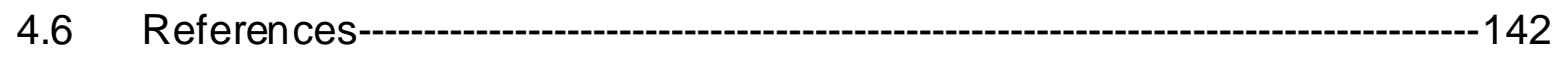


5 CHAPTER: MODELLING APPROACH TO AN ULTRAFILTRATION PROCESS FOR THE REMOVAL OF DISSOLVED AND COLLOIDAL SUBSTANCES FROM TREATED EFFLUENT FOR REUSE IN RECYCLED PAPER MANUFACTURING 147

5.1 Abstract -

5.2 Introduction -

5.3 Materials and methods--

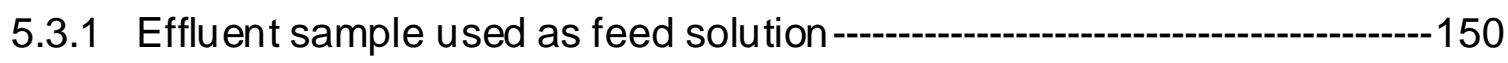

5.3.2 Membrane fouling experiments ---

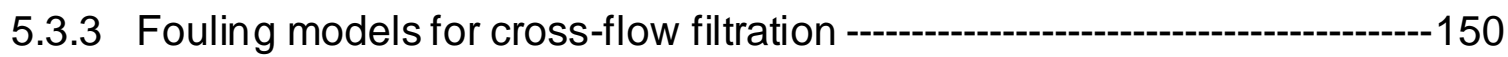

5.3.3.1 Pore blocking description--

5.3.3.2 Determination of the sum of squared deviations and average relative error 152

5.4 Results and discussion --

5.4.1 Membrane characterisation -- 154

5.4.2 Physical and chemical aspects of PMTE after the ultrafiltration process 154

5.4.3 Pore Blocking Mechanism--------155

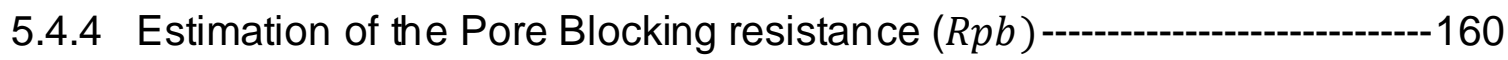

5.4.5 Predicting performance of constant-pressure filtration (membrane fouling) 165

5.4.6 Determination of membrane cleaning efficiency --_-_-167

5.5 Conclusion --171

5.6 References--

6 CHAPTER: IDENTIFICATION OF FOULANTS ON POLYETHERSULFONE (PES) MEMBRANES USED TO REMOVE COLLOIDS AND DISSOLVED MATTER FROM A PAPER MILL TREATED EFFLUENT ........................................................177

6.1 Abstract -----on

6.2 Introduction -- 178

6.3 Materials and methods--181 
6.3.1 Membrane filtration tests ---

6.3.2 Ultrafiltration fouling models ------

6.3.3 Mass Balance Analysis---o-_-

6.3.4 Identification and characterization of foulants-- 185

6.3.4.1 Field emission scanning electron microscopy (FESEM) and energy dispersive spectrophotometry (EDS). ----------o-

6.3.4.2 Attenuated total reflection-Fourier transform infrared (ATR-FTIR)

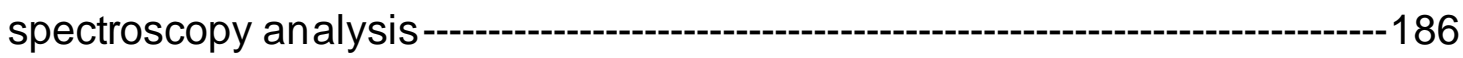

6.3.4.3 Foulant extraction ---

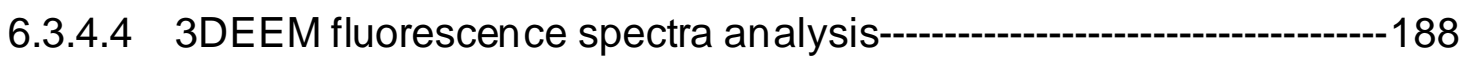

6.4 Results and discussion -- 191

6.4.1 Analysis of the influence of membrane MWCO on permeate flux and fouling mechanism ---

6.4.2 Resistance-in-series and pore blocking model analysis-------------------192

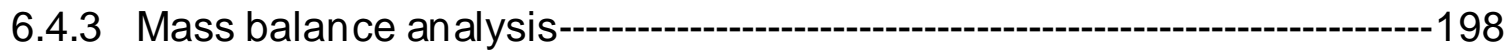

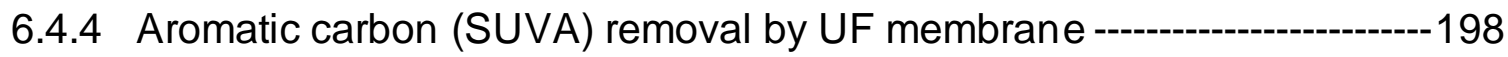

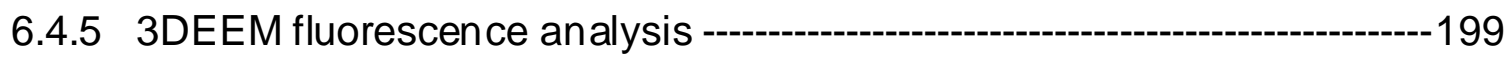

6.4.6 ATR-FTIR analysis-- 208

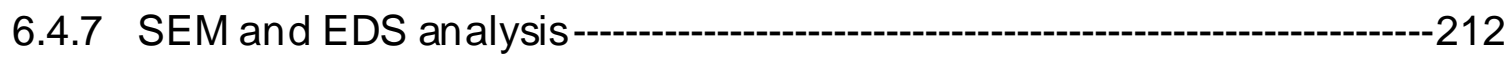

6.5 conclusions ---

6.6 References---221

7 CHAPTER : CONCLUSIONS AND FUTURE WORK RECOMMENDATIONS228

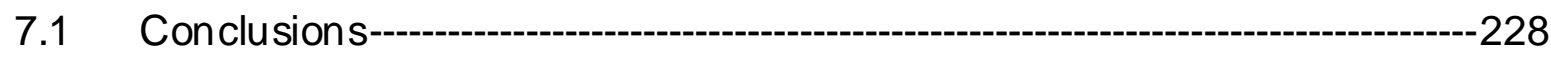

7.2 Recommendations and future work-----on

Appendix A: Factorial Design Calculations --

Appendix B: The Matlab modelling programmes. ---_o 


\section{List of Figures}

Figure 2-1 - Schematic illustration of the pulp and paper process.

Figure 2-2 - Typical layout of paper mill effluent treatment plant (Thompson et al., 2001). 26

Figure 2-3 - Basic principle of the active sludge process. 27

Figure 2-4 - IC (anaerobic reactor @ Paques) for treatment of papermill effluent....31

Figure 2-5 - Biobed EGSB anaerobic reactor (@Veolia Water Technologies) for treatment of paper mill effluent.

Figure 2-6 - membrane separation by size exclusion. 33

Figure 2-7 - Spectrum of membrane filtration. Addapted from Graff, 2012). .35

Figure 2-8 - PES composite membrane used in UF- (a) Scheme - (b) FESEM pictures (magnification $=200 \times, 100 \mu \mathrm{m}, 799 \mathrm{~V}$ ) highlighting the 3 layers. .36

Figure 2-9 - Common commercial polymers used for production UF membranes. .. 36 Figure 2-10 - Principle of dead - end filtration: (a) schematic diagram setup; (b) separation mode.

Figure 2-11 - Principle of cross flow filtration: (a) Schematic diagram of CFF system; (b) separation process.

Figure 2-12 - Configuration of a) hollow fiber cartridges and b) plate and flat sheet.39 Figure 2-13 - A schematic diagram of the various fouling mechanisms on membrane.

Figure 2-14 - Differentfouling mechanisms happening in porous membranes (Hermia, 1982).

Figure 2-15 - Excitation and emission wavelength boundaries for natural organic matter (Chen et al., 2003b).

Figure 2-16 - Locations of fluorescence Peaks A, B, C, T and M. (adopted from Hudson et al., 2007).

Figure 2-17 - Spectra of PES UF membrane and fouled membrane by paper mill treated effluent. 
Figure 2-18 - Illustration of the membrane interfacing with the ATR crystal (successively fouling layer/active layer of membrane and support layer of membrane).

Figure 3-1 - Aerial view of the wastewater treatment plant (WWTP) in a papermaking factory. Google Maps (on-line), 2019.

Figure 3-2 - Photograph of the setup for TOC-VCSN Shimadzu Analyzer used in the IEM.

Figure 3-3 - Photograph of the setup for Zetasizer Nano ZS instrument (Malvern Instruments) used in the ISIRYM.

Figure 3-4 - Schematic image of the setup with a membrane cell used for pre-filtration experiments before dead-end filtration

Figure 3-5 - Schematic image of the setup with a conventional filtration used for pretreatment before the cross-flow UF. 99

Figure 3-6 - Photographs of the experimental system. UF pilot plant with flat-sheet membrane module (Rhône-Poulenc, France). 100

Figure 3-7 - Schematic diagram for the cross-flow ultrafiltration membrane process.

Figure 3-8 - Lab-scale of the dead-end membrane filtration system with stirred cell (a) process setup photograph and (b) pilot schematic diagram. 105

Figure 4-1 Flow diagram of Taguchi method steps to optimize a UF process to remove DCS from paperboard mill treated effluent (Kumar and Singh, 2014; Roy, 1990)...119

Figure 4-2 - Volumetric flux as a function of transmembrane pressure for PES membranes of different MWCO $\left(\mathrm{T}^{\mathrm{N}}=22.5^{\circ} \mathrm{C}\right)$. 124

Figure 4-3 - Profile of the permeate flux through the operating time for each MWCO: (a) $10 \mathrm{kDa}$, (b) $50 \mathrm{kDa}$, and (c) $100 \mathrm{kDa}$. 126

Figure 4-4 - Mean effect curves for $\mathrm{S} / \mathrm{N}$ ratios for a) the average permeate flux, b) COD rejection rate, and c) the cumulative flux decline (SFD). 129

Figure 4-5 - ANOVA results for the percentage contribution of each factor to the response processes. 133 
Figure 4-6 - Effect of process parameters on mean utility value (JP; COD rejection rate, SFD).

Figure 4-7 - Permeate flux as a function of time under optimized conditions during UF of PMTE: PES $100 \mathrm{kDa}$ membrane at TMP $=2.0 \mathrm{bar}, \mathrm{CFV}=0.752 \mathrm{~m} / \mathrm{s}$, and $\mathrm{T}=15^{\circ} \mathrm{C}$.

Figure 4-8 - FESEM image of fresh and fouled membranes (PES $100 \mathrm{kDa}$ ) at different operating times, (a) clean membrane surface, (b) membrane surface fouled after 30 min filtration, (c) at the end of the UF ( 2 hours) with pore blocking and cake layer (d) membrane foulant sediments. 139

Figure 5-1- Algorithm for the parameter K optimization 152

Figure 5-2 - Pure water permeate flux vs. applied pressure. TMPs (1.0, 1.5, 2.0 and $3.0 \mathrm{bar}$ ) at $22^{\circ} \mathrm{C}$, crossflow rate of $4.5 \mathrm{~L} / \mathrm{min}$ and operation time $2 \mathrm{~h}$. The value obtained for the $R m$ for the flat sheet $10 \mathrm{kDa}$ PES membrane was $1.629 \times 10^{12}\left(\mathrm{~m}^{-1}\right)$. 154

Figure 5-3 - Hermia's pore blocking models fitting for recycled paper wastewater 10 kDa PES membrane filtration experiments, at 3 bar. 156

Figure 5-4 - Hermia's pore blocking models fitting for recycled paper wastewater 10 kDa PES membrane filtration experiments, at 2 bar. 157

Figure 5-5 -Hermia's pore blocking models fitting for recycled paper wastewater 10 kDa PES membrane filtration experiments, at 1 bar. 157

Figure 5-6 - Comparison of predictive pore blocking resistances as a function of filtration time among different models at different TMPs for UF PMTE with $10 \mathrm{kDa}$ PES membrane: (a) 1.0 bar, (b) 2.0 bar and (c) 3.0 bar. 162

Figure 5-7 - Experimental and predicted pore blocking resistance distribution forPMTE at $10 \mathrm{kDa}$ PES membrane and different TMPs. Averaged values of resistance was used and the data was modeled using Matlab@ modelling programmes (Appendix B).

Figure 5-8 - Comparison between experimental flux decline and theoretical model for permeate flux with cross flow for a flat-sheet $10 \mathrm{kDa}$ PES membrane in cross flow filtration mode as calculated from Equation 5-9 (conditions: TMP $=3.0$ bar, $\mathrm{Cg}=0.7$, $\left.\varepsilon=0.3, C_{0}=0.2 \mathrm{~g} / \mathrm{L}, \mathrm{ap}=158 \mathrm{~nm}, \mathrm{Rm}=1.65 \times 10^{12} \mathrm{~m}^{-1}\right)$. 165 
Figure 5-9 - Resistance of the cake layer and cake thickness as a function of UF time $(8 \mathrm{~h})$ in flat-sheet, crossflow filtration at constant pressure . Conditions TMP $=3.0$ bar, $\mathrm{Cg}=0.7, \varepsilon=0.3, \mathrm{C}_{0}=0.2 \mathrm{~g} / \mathrm{L}, \mathrm{ap}=158 \mathrm{~nm}, \mathrm{Rm}=1.65 \times 10^{12} \mathrm{~m}^{-1}, \mathrm{rc}=3.01 \times 10^{12}\left(\mathrm{~m}^{-2}\right)$.

Figure 5-10 - Normalised flux recovery $(\mathrm{Jp}(\mathrm{t}) / \mathrm{J} 0)$ by chemical and hydraulic methods. Initial permeate flux was $55.12 \pm 1.0 \mathrm{~L} / \mathrm{m}^{2} \mathrm{~h}$ and resistance by total fouling $2.26 \times 10^{13}$ $\mathrm{m}^{-1}$. 168

Figure 5-11 - Membrane resistance removal at various filtration cycles by chemical and hydraulic methods.

Figure 6-1 - Flow chart of the recovery process of water in the cardboard paper making process.

Figure 6-2 - Field Emission Scanning Electron Microscope (FESEM) (ZEISS ULTRA 55 model. Oxford Instruments, UK) used in the ISIRYM. 186

Figure 6-3 - FT-IR spectrometer with universal ATR Sampling Attachment (Thermo Electron Corporation, USA) used in the IEM.

Figure 6-4 - Rotavapor extraction system and vacuumunitused to foulants extraction, used in the IEM. 188

Figure 6-5 - Photograph of Perkin-Elmer, LS-55 fluorescence spectrometer (PerkinEImer, USA), used in the IEM.

Figure 6-6 - Normalized flux vs. specific filtration volume, during the filtration of PMTE using $10 \mathrm{kDa}, 50 \mathrm{kDa}$ and $100 \mathrm{kDa}$ UF-PES membranes. The applied TMP was 2.0 bar, at room temperature and TOC concentration of the feed solution about 78.0 \pm 2.5 $\mathrm{mg} \cdot \mathrm{L}^{-1}$

Figure 6-7 - Specific resistance $(\alpha)$ and fouling resistance $(R f)$ calculated using the resistance-in series-model for (a) $10 \mathrm{kDa}$ MWCO, (b) $50 \mathrm{kDa}$ MWCO and (c) $100 \mathrm{kDa}$ MWCO membranes.

Figure 6-8 - Comparison between experimental average permeate flux and predicted average flux fitted by dead-end pore blocking models Equation 66 - Equation 6 9:(a) 10 kDa MWCO, (b) 50 kDa MWCO and (c) 100 kDa MWCO membranes.

Figure 6-9 - Carbon mass balances during UF for different MWCO, mfeed $=19.76 \pm 0.5$ mg.C 
Figure 6-10 - 3DEEM fluorescence spectra for (a) feed solution (prefiltered with 0.45 $\mu \mathrm{m}$ filter); (b) permeate $10 \mathrm{kDa}$; (c) permeate $50 \mathrm{kDa}$; and (d) permeate $100 \mathrm{kDa}$. Region I and II = aromatic protein-like substances I and II respectively; Region III = fulvic acid-like substances; Region IV = soluble microbial by-products; Region V = humic acid-like substances.

Figure 6-11 - 3D view of fluorescence spectra of foulants extracted from fouled membranes at the end of filtration (dead-endfiltration protocol): (a) $10 \mathrm{kDa}$; (b) $50 \mathrm{kDa}$, and (c) $100 \mathrm{kDa}$. 206

Figure 6-12 - Volumen of fluorescence distribution for the foulants extracted of three different PES membranes. 207

Figure 6-13 - ATR-FTIR spectra comparison of fresh PES membrane and fouled membrane: (a) $10 \mathrm{kDa}$; (b) $50 \mathrm{kDa}$, and (c) $100 \mathrm{kDa}$ (the IR spectrum comparison between MWCO membranes were almost the same) and DCS- fouled PES membranes ( $10 \mathrm{kDa}, 50 \mathrm{kDa}$ and $100 \mathrm{kDa}$ ) by PMTE filtration (d). 210

Figure 6-14 - FESEM images of the membrane surfaces (a) fresh $10 \mathrm{kDa}$ MWCO; (b) fouled $10 \mathrm{kDa}$ MWCO; (c) cleaned $10 \mathrm{kDa}$ MWCO, (d) fresh $50 \mathrm{kDa}$ MWCO; (e) fouled 50 kDa MWCO; (f) cleaned 50 kDa MWCO, (g) fresh 100 kDa MWCO; (h) fouled 100 kDa MWCO; (i) cleaned 100 kDa MWCO. 215

Figure 6-15 - EDS spectrum of the membrane surfaces (a) fresh 10 kDa MWCO; (b) fouled $10 \mathrm{kDa}$ MWCO; (c) fresh $50 \mathrm{kDa}$ MWCO; (d) fouled $50 \mathrm{kDa}$ MWCO; (e) fresh 100 kDa MWCO; (f) fouled 100 kDa MWCO 


\section{List of Tables}

Table 1-1.Physical-chemical characterization of recycled paper wastewater from Zwain et al. (2013).

Table 2-1- Removal efficiency of differentaerobic treatment processes applied in pulpand-paper wastewaters. Adopted from (Ashrafi et al., 2015). 28

Table 2-2 - Removal efficiency of different anaerobic treatment processes applied in pulp-and-paper wastewaters. Adopted from (Ashrafi et al., 2015).

Table 2-3 -Classification of membrane Mulder processes with pore size and pressuredrive (adapted from Mulder, 1996).

Table 2-4 - Classification of membrane resistances. .52

Table 2-5 - Sources of DCS in various pulp and paper Process Waters adapted from Hubbe et al. (2012).

Table 2-5 - Guidelines on the nature of DOM according to SUVA. Addapted from (Cunha, 2014; Edzwald and Tobiason, 1999)

Table 2-6 - Commonly identified PARAFAC components and their corresponding peaks identified in Coble. (1996). Adapted from B. Fellman et al., 2010 and Hudson et al., 2007.

Table 2-7 - The most common peaks from PES and the residual fouling found in the IR spectrum.

Table 2-8 - Summary comparing analytical techniques for foulant identification and characterization of membrane fouling. Addapted from (Chen et al., 2018)..... 68

Table 3-1 - Average compositions of the paper mill treated effluent (anaerobic and aerobic treatment) used in the experiments.

Table 3-2 - Technical data on the membranes used in this study. 98

Table 4-1 - Average compositions of the paperboard mill treated effluent (biologically treated wastewater) used in the experiments.

Table 4-2 - Process parameters and their levels.

Table 4-3 - Experimental layout using L9 (34) orthogonal array in accordance with the Taguchi method 
Table 4-4 - Taguchi orthogonal array $L_{9}\left(3^{4}\right)$ for the operating parameters and experimental response parameters.

Table 4-5 - Signal-to-noise results (mean \pm standard deviation (SD), three repetitions for each experimental condition). 128

Table 4-6 - Analysis of variance (ANOVA) results for average permeate flux, COD rejection, and SFD for each factor.

Table 4-7 - Individual Taguchi predictions for average permeate flux, COD rejection rate and SFD. 134

Table 4-8 - Pairwise comparison matrix. 135

Table 4-9 - Utility value based on UF responses (JP, COD rejection, SFD). 135

Table 4-10 - ANOVA analysis results for multi-response UF (overall utility function). 136

Table 4-11 - Optimum conditions for multi-response UF predicted using the utility concept.

Table 4-12- Permeate quality (process performance) underoptimum conditions, at the end of 2 hours operating.

Table 4-13 - Summary and comparison of experimental and predicted optimal conditions for PMTE. 140

Table 5-1 - Fouling mechanism for constant flow rate in cross-flow UF (Field et al., 1995).

Table 5-2 - Physical-chemical parameters of the effluent treated by conversional filtration and ultrafiltration separation. 155

Table 5-3 - Pore blocking $R^{2}$, fitting of Hermia's models. Values for recycled paper wastewater $10 \mathrm{kDa}$ MWCO PES membrane, ultrafiltration experiments. 159

Table 5-4 - Pore blocking standard error of the estimate and coefficient of residual variation between experimental data and Hermia's models against TMP. 164

Table 5-5 - Membrane flux recovery after each cleaning step with DI water in backwash and $\mathrm{NaOH}$. Initial permeate flux $55.5 \pm 1.0 \mathrm{~L} / \mathrm{m}^{2} \mathrm{~h}$. 169

Table 6-1 - Summary of the fouling mechanisms by blocking models during dead-end filtration. 184 
Table 6-2 - Characteristics of the associated fluorophores detected by 3DEEM according to W. Chen et al. (2003b). 190

Table 6-3 - Permeate flux, flux reduction and total flux recovery after cleaning steps (relaxation and backwashing) from different MWCO membranes. 192

Table 6-4 - Values of pore blocking parameters, comparison between the experimental and predicted average permeate flux and the model fitting accuracy $\left(R^{2}\right)$ 195

Table 6-5 - Aromatic carbon (SUVA) in the PMTE and permeates, at 2.0 bar and different MWCO. 199

Table 6-6 - Volume of fluorescence $\Phi i$ and the reduction in the concentration of fluorescent compounds after UF. 203

Table 6-7- Peaks and assignments of infrared spectra for clean and fouled membranes. 211

Table 6-8 - Inorganic composition of fresh and fouled membranes. 218 




\section{CHAPTER: INTRODUCTION}




\subsection{Background of the project}

The pulp and paper (P\&P) industry is ranked as the world's third largest consumer of fresh water (Sevimli, 2005) and an important producer of wastewater and differentorganic and inorganic contaminants (Chakraborty et al., 2019; Mandeep et al., 2020). Depending on the type of processes used in paper manufacture, the integration between production and environmental protection is one of the key topics in the paper industry.

According to the CEPI (2017), Europe is the second largest producer of paper and paperboard with $22.7 \%$ (91.39 million tons) of world production (Asia $45.3 \%$ and North America $21.1 \%$ ), and the third largest consumer with $18.9 \%$ (76.28 million tons), behind Asia the leader with 46.6\%, and North America with $19.2 \%$, making it one of the most important industries in the European economic sector.

The paper industries hold an important place in Spanish economy, as Spain is one of the European leaders in paper recycling, with $84 \%$ of the raw materials used by the paper industry containing recovered fibers (RCFs) (CEPI, 2017), which leading to a decrease in the amount of the wastewater generated, due to the RCF mills being less water consumer when compared with virgin fiber P\&P producers (Hong and Li, 2012; Kamali et al., 2016). However, we cannot forget that water is, also, an essential raw material for manufacturing paper and paperboard, and effluent treatment is a critical part of the process (Rajkumar, 2016). In order to minimize the amount of fresh water used and the volume of effluent discharged, the European Commission has described the best available techniques (BAT) to be adopted by the P\&P industry (Suhret al., 2015).

Wastewater from the paper industry is challenging to be treat due to their variability, complexity and toxicity besides that contains a high biodegradable organic matter loading and its volume is high in relation to production (Scholes et al., 2019). Paper mill wastewater carries significant quantities of fibre (losses with effluent $0.5-5 \%$ of total fibre amount), filler, fines and other wet-end additives that contribute to total suspended solids (TSS), chemical oxygen demand (COD) and biological oxygen demand (BOD). TSS varies significantly from mill to mill, based on the type of internal clarification equipment used, equipment arrangement and design philosophy. COD depends on the amount of suspended solids such as fibre, fines, and other chemically oxidisable wet-end additives such as starch. BOD is high du e to the presence of large amounts of oxidisable materials, such as fibre, fines, starch, wet and dry strength resins, drainage aids, dyes, sizing 
materials and other dissolved organics (Haq and Raj, 2020; Nuortila-Jokinen, 2000; Nuortila-Jokinen et al., 2004).

Furthermore, the volume, properties and characteristics of P\&P generated wastewater depend on several factors such as the type of paper production (packaging paper, corrugated cardboard, light-weight coated paper, printing and writing paper), the raw materials used in the manufacturing process, which can be from virgin fibre or (RCFs), the production process employed, applied technologies, additive chemicals and the amount of water consumed. It is important to mention that the wastewater generated in a $\mathrm{RCF}$ mill is quite small compared to that from a virgin P\&P production process (Kamali and Khodaparast, 2015a; Tiku et al., 2007).

In fact, P\&P industry recovery of waste papers such as mixed office waste, old cardboard, old newsprint and old corrugated containers has increased over recent decades, due of a number of favourable factors such as raw material economy, natural resources saving, reductions in solid waste and effluent (Van Beukering and Bouman, 2001). However, when recycled paper is used (RCF mills) the effluent is characterized by a variable loading of fibres, pulping additive chemicals and other impurities such as short fines and fillers, which are generally not very soluble. In addition, the concentration of dissolved organic pollutants is particularly high and directly related to the origin of the waste papers (Miranda Carreño et al., 2009; Monte et al., 2009). Zwain et al. (2013) studied some physical-chemical characteristics of recycled paper wastewater as presented in Table 1-1 
Table 1-1.Physical-chemical characterization of recycled paper wastewater from Zwain et al. (2013).

\begin{tabular}{ll}
\hline \hline Parameter & Range \\
$\mathrm{pH}$ & $6.2-7.8 \mathrm{a}$ \\
Floc size & $08-300$ \\
Temperature & $35-45$ \\
Chemical oxygen demand (COD) & $3380-4930$ \\
Biochemical oxygen demand (BOD) & $1650-2565$ \\
BOD5/COD & $0.488-0.52$ \\
Alkalinity & $300-385$ \\
Ca & $375-420$ \\
Mg & $10-15$ \\
Total solids (TS) & $3530-6163$ \\
Total dissolved solids (TDS) & $1630-3025$ \\
Total suspended solids (TSS) & $1900-3138$ \\
Total volatile solid (VSS) & $840-2920$ \\
\hline \hline
\end{tabular}

* Parameters are in $\mathrm{mg} / \mathrm{L}$ except $\mathrm{pH}, \mathrm{BOD} 5 / \mathrm{COD}$, temperature in ${ }^{\circ} \mathrm{C}$ and floc size in $\mu \mathrm{m}$

A number of conventional processes have previously been used to treat the different types of paper mill wastewater including coagulation and flocculation (Ahmad et al., 2008; Yang et al., 2019), adsorption (Temmink and Grolle, 2005; Zhang and Chuang, 2001), advanced oxidation (Catalkaya and Kargi, 2008; Pérez et al., 2002) and membrane filtration (Ejraei et al., 2019; Gönder et al., 2012; Liu et al., 2014; Nuortila-Jokinen et al., 2004; Puro et al., 2010; Zaidi et al., 1992)..

It is worth mentioning that paper mills have their own wastewater treatment plants, but sometimes this treatment does not achieve the pollutant loadings permissible under current regulations (Sharma et al., 2020). As a result, the wastewater must be sent to municipal WWTPs, causing problems in designed operational conditions. Most pulp and paper mills treat their effluent by using an activated sludge process.

However, this biologically treated effluent still contains significant amounts of colour compounds, microorganisms, recalcitrant organics and a minor amount of biodegradable organics as well as suspended solids. Therefore, the biological treatment does not significantly reduce the inorganic content of the effluent. As a result, the water is still not sufficiently clean after this process for reuse in the production of most paper. Pulp and paper mill effluents can be reused for the production of different types of paper and 
cardboard (Bulow et al., 2003; Chen et al., 2015b), but process water cannot be recycled easily because dissolved and colloidal substances (DCS) and electrolytes become en riched with water recycling. This has the effect of adversely affecting paper machine operability and paper quality. DCS can be defined as the sum of the organic matter, polyelectrolytes, other dissolved material, and suspended particles (less than $1 \mu \mathrm{m}$ ) present in process water or paper mill effluent (Chen et al., 2015a). In general, the DCS in the process comes from fibre extractives, pulp and the chemical additives consumed during manufacturing and they can also react with electrolytes $\mathrm{Ca}^{2+}$ and $\mathrm{Mg}^{2+}$ (Chen et al., 2015a; Hubbe et al., 2012; Ordóñez et al., 2010; Yuan et al., 2011).

The degree to which these impurities need to be removed before reuse of the water is not well known. However, the higher the quality of the paper produced, the cleaner the water used in manufacturing should be (Möbius, 1988; Pokhrel and Viraraghavan, 2004). Recently, membrane separation technology has attracted more and more attention as an alternative way to treat paper mill wastewater. Some nanofiltration (NF), ultrafiltration (UF) and reverse osmosis $(\mathrm{RO})$ membrane filtration plants have been installed in pulp and paper mills to purify secondary and tertiary effluents using external biological treatment. The major advantage of the membrane separation technology is that it can save energy, reduce the carbon footprint and simplify operation. Many reports have demonstrated the applicability of membrane technology to pulp and paper mill wastewater (Pokhrel and Viraraghavan, 2004; Thuvander et al., 2019). Ultrafiltration can be used as an advanced tertiary treatment to remove suspended solids and DCS during the treatment of paper industry effluent.

This allows the re-utilisation of process water and reduces fresh water consumption. However, membrane fouling limits the application and use of UF and, currently, this treatment technology can only be used to filter paper mill effluent that has been pretreated and meets discharge standards (Puro et al., 2011a). DCS might play a number of different roles in membrane fouling. Colloidal substances larger than the pores cannot pass through the membrane and they will be deposited on the membrane surface blocking the pores. Dissolved substances that are smaller than the membrane pore-size are adsorbed within the pores and/or deposited within the membrane, shrinking the pore diameter and increasing membrane resistance. In addition, once pores are blocked, other DCS can form a cake on top of the membrane, adding additional resistance via another porous layer covering the membrane (Carroll et al., 2000; Sanaei and Cummings, 2017). 
According to research performed by Chen et al. (2015), reversible membrane fouling during ultrafiltration accounted for $85.52 \%$ of total fouling. It primarily originated from retention aids, drainage aids, polyacrylamide and wet strength resins. While irreversible adsorptive fouling accounted for $14.48 \%$ and mostly came from sizing agents, coating chemicals (oxidants for polyester or resin and polyester or resin surface sizing agents) and other sources. Moreover, the presence of dissolved multivalent metal ions, especially $\mathrm{Ca}^{2+}$, accelerated membrane fouling (Puro et al., 2002). Some research aimed at reducing biofilm formation has demonstrated that bacterial cells (Pseudomonas fluorescens) on cellulose fibres can affect retention (Pereira et al., 2001). Bajpai, (2015) studied the types of microorganisms encountered in the papermaking process that can contribute to fouling. It was found they include aerobic spore-forming bacteria (Bacillus), aerobic non-sporulating bacteria (e.g. Acinetobacter and Alcaligenes) and anaerobic bacteria (e.g. Desulfovibrio).

Membrane and operating conditions selection are important in minimizing membrane fouling. Being that, fouling in filtration membranes results in a sharp decline in permeate flux, membrane cleaning, increase in maintenance costs and, thus, changes in membranes selectivity (Gönder et al., 2012; Kamali and Khodaparast, 2015; Mänttäri et al., 1997). A review of the literature revealed that an increasing number of studies are being conducted using design of experiments (DOEs) approaches in the membrane technology field to optimize operating conditions (Gönder et al., 2012; Hesampour et al., 2008; Khaire and Gogate, 2020; Pourjafar et al., 2013; Reyhani et al., 2015, 2015; Rezvanpour et al., 2009; Salahi et al., 2010). It is worth mentioning that this approach is becoming popular because it is easy to adopt and applies an efficient method for optimizing the process parameters.

In addiction, to efficiently control membrane fouling in the ultrafiltration (UF) process, it is important to understand which components in the effluent play a major role in membrane fouling. Thus, 3D fluorescence excitation-emission matrix (3DEEM) and conventional technics can, therefore, be used as a powerful technique for the identification and characterization of the foulants on a membrane from a paper mill treated effluent (Chen et al., 2015a, 2003b; Puro et al., 2002a, 2010). It can also contribute with information to establish strategies for process optimization in order to prevent and eliminate this undesirable phenomenon (Peiris et al., 2010; Peldszus et al., 2011a; Yu et al., 2014; Z. Wang et al., 2009). 
An ultrafiltration process for the removal of dissolved and colloidal substances from a paper mill effluent for reuse in the manufacturing was studied in this research. The removal efficiency, process performance and membrane fouling was analyzed based on optimization of the operating conditions via statistical experimental design by Taguchi methodology, analysis of fouling mechanism and permeate flux decline, besides to use 3DEEM and conventional technics for understand the chemical composition and possible origins of membrane foulants.

\subsection{Motivation for work}

Several conventional treatment methods have been used to treat the wastewater from different paper mills, but, in some cases, the conventional methods are insufficient to comply with the most stringentenvironmental regulations on effluentquality and/orfor the process water to be reused in papermaking (Shankar et al., 2014). Factories, therefore, must improve their treatment plants if they are to achieve the pollutant loadings permissible under current regulations and/or reuse their process water.

Faced with the necessity for process optimization, membrane separation technology has attracted increasing attention as a tertiary treatment for biologically treated effluents from paper mills, particularly as it facilitates subsequent effluent recycling (Chen et al., 2015a; Puro et al., 2010; Zaidi et al., 1992). However, membrane fouling continues to be one of the main limitations and challenges to the wider-scale application and use of membrane technology in paper mill effluent treatment (Beril Gönder et al., 2011; Saranya et al., 2019; $\mathrm{Xu}$ et al., 2019). The membrane fouling is a complex phenomenon and is affected by several factors, such as feed solution, operational conditions of the process and membrane characteristics (Mulder, 1996), besides to increase the operational cost as a result of the decrease in the permeate flux and Transmembrane pressure (TMP) to membrane fouling resistances (Wang et al., 2008).

Thus, to efficiently control membrane fouling in the ultrafiltration (UF) process, it is important to understand which components in the effluent play a major role in membrane fouling. In pulp and paper mill effluent, dissolved and colloidal substances (DCS) have been considered to be the major membrane foulants (Chen et al., 2015a; Hubbe et al., 2012; Puro et al., 2002a), comprised of protein-like, polysaccharide-like compounds, fatty acids, resin acids and presence of inorganic foulants such as metal ions and especially $\mathrm{Ca}^{2+}$ (Singh and Chandra, 2019). 
Previous studies on membrane filtration of paper mill wastewater have focused on the permeate flux and quality. The effect of operating conditions on process performance, and the investigation of chemical composition and possible origins of UF membrane foulants have received little attention. Therefore, in this study the performances of membrane technology such as ultrafiltration (UF) were tested in pilot plants, in order to optimize the separation process. Theoretical modeling, different membrane molecular weight cut - off (MWCO), different operating conditions and module systems (dead-end and cross-flow) were tested to increase membrane productivity and to assure a chemical purification suitable for water recycling and environmental rregulations in the paper manufacturing process. In addiction, this research have the aim to provide more detailed understanding of the membrane fouling behavior during the UF process for the removal of the DCS come from a paper mill secondary effluent

\subsection{Goal and research objectives}

As previously commented UF is an attractive process for paper mill wastewater treatment and it can be used as an advanced tertiary treatment to remove suspended solids and DCS during the treatment of paper industry effluent in order to facilitate the reuse of the treated wastewater and reduce fresh water consumption. However, membrane fouling is still a limiting factor for the adoption and use of UF on a large scale in paper manufacturing applications. Through that limitation and challenge, this research was focused on studying the influence of differentoperating conditions on membrane fouling behavior and characterization, in an ultrafiltration processes with polyethersulfone (PES) membranes used to remove colloids and dissolved matter from a paper mill treated effluent for reuse in recycled paper manufacturing.

The main objectives of this research were can be summarized as follows:

1. To determinate the effect of operating conditions such as transmembrane pressure (TMP), cross-flow velocity (CFV), temperature and molecular weight cut-off (MWCO) on the average permeate flux, COD rejection rate and cumulative flux decline (SFD), in addition to determining the optimum conditions for the given sets of values and to find the best response parameters by using Taguchi experimental design and the utility concept.

2. To study the fouling behavior, especially on the effects of dissolved and colloidal substances on membrane fouling mechanisms using the pore blocking model for 
tangential filtration adapted from Hermia's dead-end filtration laws, combined pore blockage-cake filtration model, constantpressure filtration and resistance-in-series model.

3. To understand the chemical composition and possible origins of UF membrane foulants with technics such as chemical analysis, field scanning electron microscopy (FESEM), SEM-energy-dispersive spectrophotometry (EDS), attenuated total reflection-Fourier transform infrared (ATR-FTIR) spectroscopy and 3D fluorescence excitation-emission matrix (3DEEM) in the remove colloids and dissolved matter from a paper mill treated effluent (PMTE). Resistance-inseries and Hermia's model were also used to analyze the predominant fouling mechanism takes place on each membrane and how it affects the permeate flux.

\subsection{Outline (structure) of this study}

This thesis has been structured into seven chapters as described below:

Chapter 1 is a general introduction on the background of the study, research motivation, and the needs to provide more detailed understanding of the membrane fouling behavior during the UF process for the removal of DCS from a paper mill secondary effluent. Additionally, this chapter also includes research goal and objectives of the study.

Chapter 2 is a review of the perspective and challenges for the pulp and paper mill manufacturing, effluent characteristics and wastewater treatment in paper in dustry. Also includes membrane filtration fundamentals, mathematical models for membrane fouling analysis and methodologies and technics to membrane foulants characterization and identification.

Chapter 3 this chapter describes the development of the materials and methods common for the filtration set-up, membrane fouling experiments and, general analytical methods and technics to foulants identification. Much of the study contained into this thesis, more specific materials and methods can be found within the each individual chapter.

Chapter 4 describes how to find optimal operating conditions of four controlling parameters, i.e. transmembrane pressure (TMP), cross-flow velocity (CFV), temperature and molecular weight cut-off (MWCO) for maximizing the average permeate flux $\left(\bar{J}_{P}\right)$ and chemical oxygen demand (COD) rejection, and minimizing the cumulative flux decline (SFD) using Taguchi method and utility concept for a cross-flow UF process in pilot scale. 
Chapter 5 the approach has been to examine and model the decline in permeate flux resulting from membrane fouled by DCS. UF experiments were carried outin a laboratoryscale plant using a $10 \mathrm{kDa}$ PES UF membrane in a flat sheet module. TMP (1-3 bar) and crossflow rate $(1.5-4.5 \mathrm{~L} / \mathrm{min})$ were varied during the experiments, at constant temperature $\left(22 \pm 0.5^{\circ} \mathrm{C}\right)$. The results from UF tests were expressed in terms of permeate flux (Jp) as a function of time to check modified Hermia's models adapted to crossflow filtration and cake formation in constant-pressure filtration.

Chapter 6 describes the Identification, characterization and possible origins of UF membrane fouling used to remove DCS from a PMTE. Techniques such as chemical analysis, FESEM, SEM-EDS, ATR-FTIR and 3DEEM analysis were applied to understand which fraction of the foulants caused the reversible and irreversible fouling. The proof was performed at laboratory in dead-end UF.

Chapter 7 provides a summary of conclusions and future work recommendations. 


\section{$1.5 \quad$ References}

Ahmad, A., Wong, S., Teng, T., Zuhairi, A., 2008. Improvement of alum and PACl coagulation by polyacrylamides (PAMs) for the treatment of pulp and paper mill wastewater. Chemical Engineering Journal 137, 510-517. https://doi.org/10.1016/j.cej.2007.03.088

Bajpai, P., 2015. Pulpand paper industry : microbiological issues in papermaking., 5th ed. Elsevier.

Beril Gönder, Z., Arayici, S., Barlas, H., 2011. Advanced treatment of pulp and paper mill wastewater by nanofiltration process: Effects of operating conditions on membrane fouling. Separation and Purification Technology 76, 292-302. https://doi.org/10.1016/j.seppur.2010.10.018

Bulow, C., Pingen, G., Hamm, U., 2003. Water system closure in a recovered paper processing paper mill with special regard to the calcium carbonate problem, in: Research Gate. Presented at the Proc. 28th EUCEPA: Sustainable Development for the Pulp and Paper Industry, Lisbon, Portugal, p. 30.

Carroll, T., King, S., Gray, S.R., Bolto, B.A., Booker, N.A., 2000. The fouling of microfiltration membranes by NOM after coagulation treatment. Water Research 34, 2861-2868. https://doi.org/10.1016/S0043-1354(00)00051-8

Catalkaya, E.C., Kargi, F., 2008. Advanced oxidation treatment of pulp mill effluent for TOC and toxicity removals. Journal of Environmental Management 87, 396-404. https://doi.org/10.1016/j.jenvman.2007.01.016

CEPI, 2017. Key statistics report 2017 | CEPI - CONFEDERATION OF EUROPEAN PAPER INDUSTRIES [WWW Document]. URL http://www.cepi.org/keystatistics2017 (accessed 9.20.18).

Chakraborty, D., Shelvapulle, S., Reddy, K.R., Kulkarni, R.V., Puttaiahgowda, Y.M., Naveen, S., Raghu, A.V., 2019. Integration of biological pre-treatment methods for increased energy recovery from paper and pulp biosludge. Journal of $\begin{array}{lll}\text { Microbiological } \quad \text { Methods } & \text { 93-100. }\end{array}$ https://doi.org/10.1016/j.mimet.2019.03.015

Chen, C., Mao, S., Wang, J., Bao, J., Xu, H., Su, W., Dai, H., 2015. Application of Ultrafiltration in a Paper Mill: Process Water Reuse and Membrane Fouling 
Analysis.

BioResources

10,

2376-2391.

https://doi.org/10.15376/biores.10.2.2376-2391

Chen, W., Westerhoff, P., Leenheer, J.A., Booksh, K., 2003b. Fluorescence Excitation-Emission Matrix Regional Integration to Quantify Spectra for Dissolved Organic Matter. Environmental Science \& Technology 37, 5701-5710. https://doi.org/10.1021/es034354c

Ejraei, A., Aroon, M.A., Ziarati Saravani, A., 2019. Wastewater treatment using a hybrid system combining adsorption, photocatalytic degradation and membrane filtration processes. Journal of Water Process Engineering 28, 45-53. https://doi.org/10.1016/j.jwpe.2019.01.003

Gönder, Z.B., Arayici, S., Barlas, H., 2012. Treatment of Pulp and Paper Mill Wastewater Using Utrafiltration Process: Optimization of the Fouling and Rejections. Industrial \& Engineering Chemistry Research 51, 6184-6195. https://doi.org/10.1021/ie2024504

Haq, I., Raj, A., 2020. Pulp and Paper Mill Wastewater: Ecotoxicological Effects and Bioremediation Approaches for Environmental Safety, in: Bharagava, R.N., Saxena, G. (Eds.), Bioremediation of Industrial Waste for Environmental Safety: Volume II: Biological Agents and Methods for Industrial Waste Management. Springer, Singapore, pp. 333-356. https://doi.org/10.1007/978-981-13-3426-9_14

Hesampour, M., Krzyzaniak, A., Nyström, M., 2008. The influence of different factors on the stability and ultrafiltration of emulsified oil in water. Journal of Membrane Science 325, 199-208. https://doi.org/10.1016/j.memsci.2008.07.048

Hong, J., Li, X., 2012. Environmental assessment of recycled printing and writing paper: A case study in China. Waste Management 32, 264-270. https://doi.org/10.1016/j.wasman.2011.09.026

Hubbe, M.A., Sundberg, A., Mocchiutti, P., Ni, Y., Pelton, R., 2012. DISSOLVED AND COLLOIDAL SUBSTANCES (DCS) AND THE CHARGE DEMAND OF PAPERMAKING PROCESS WATERS AND SUSPENSIONS: A REVIEW. BioResources 7, 6109-6193. https://doi.org/10.15376/biores.7.4.6109-6193

Kamali, M., Gameiro, T., Costa, M.E.V., Capela, I., 2016. Anaerobic digestion of pulp and paper mill wastes - An overview of the developments and improvement 
opportunities. Chemical Engineering Journal 298, 162-182. https://doi.org/10.1016/j.cej.2016.03.119

Kamali, M., Khodaparast,Z., 2015. Review on recent developments on pulp and paper mill wastewater treatment. Ecotoxicology and Environmental Safety 114, 326-342. https://doi.org/10.1016/j.ecoenv.2014.05.005

Khaire, R.A., Gogate, P.R., 2020. Optimization of ultrafiltration of whey using Taguchi method for maximizing recovery of lactose. Separation and Purification Technology 248, 117063. https://doi.org/10.1016/j.seppur.2020.117063

Liu, Y., Li, X., Yang, Y., Ye, W., Ji, S., Ren, J., Zhou, Z., 2014. Analysis of the major particle-size based foulants responsible for ultrafiltration membrane fouling in polluted raw water. Desalination 347, 191-198. https://doi.org/10.1016/j.desal.2014.05.039

Mandeep, Kumar Gupta, G., Shukla, P., 2020. Insights into the resources generation from pulp and paper industry wastes: Challenges, perspectives and innovations. $\begin{array}{lll}\text { Bioresource } & \text { Technology } & 292496 .\end{array}$ https://doi.org/10.1016/j.biortech.2019.122496

Mänttäri, M., Nuortila-Jokinen, J., Nyström, M., 1997. Evaluation of nanofiltration membranes for filtration of paper mill total effluent. Filtration \& Separation 34, 275280. https://doi.org/10.1016/S0015-1882(97)84794-5

Miranda Carreño, R., Blanco Suárez, Á., Negro Álvarez, C.M., Miranda Carreño, R., Blanco Suárez, Á., Negro Álvarez, C.M., 2009. Accumulation of dissolved and colloidal material in papermaking - Application to simulation. Chemical Engineering Journal 148, 385-393.

Möbius, C.H., 1988. BIOLOGICAL TREATMENT OF PAPERMILL WASTEWATER IN AN ACTIVATED SLUDGE CASCADE REACTOR, in: Lijklema, L., Imhoff, K.R., Ives, K.J., Jenkins, D., Ludwig, R.G., Suzuki, M., Toerien, D.F., Wheatland, A.B., Milburn, A., Izod, E.J. (Eds.), Water Pollution Research and Control Brighton. Pergamon, pp. 1825-1828. https://doi.org/10.1016/B978-1-4832-8439-2.50198-X

Monte, M.C., Fuente, E., Blanco, A., Negro, C., 2009. Waste management from pulp and paper production in the European Union. Waste Management 29, 293-308. https://doi.org/10.1016/j.wasman.2008.02.002 
Mulder, J., 1996. Basic Principles of Membrane Technology, 2nd ed. Springer Netherlands.

Nuortila-Jokinen, J., 2000. Fresh Water Minimization by Membrane Filtration in the Pulp and Paper Industry. Wastewater Recycle, Reu se, and Reclamation 1, 372382.

Nuortila-Jokinen, J., Mänttäri, M., Huuhilo, T., Kallioinen, M., Nyström, M., 2004. Water circuit closure with membrane technology in the pulp and paper industry. Water science and technology: a journal of the International Association on Water Pollution Research 50, 217-27. https://doi.org/10.2166/wst.2004.0199

Ordóñez, R., Hermosilla, D., San Pío, I., Blanco, A., 2010. Replacement of fresh water use by final effluent recovery in a highly optimized $100 \%$ recovered paper mill. Water Sci. Technol. 62, 1694-1703. https://doi.org/10.2166/wst.2010.933

Peiris, R.H., Hallé, C., Budman, H., Moresoli, C., Peldszus, S., Huck, P.M., Legge, R.L., 2010. Identifying fouling events in a membrane-based drinking water treatment process using principal component analysis of fluorescence excitationemission matrices. Water Research 44, 185-194. https://doi.org/10.1016/j.watres.2009.09.036

Peldszus, S., Hallé, C., Peiris, R.H., Hamouda, M., Jin, X., Legge, R.L., Budman, H., Moresoli, C., Huck, P.M., 2011. Reversible and irreversible low-pressure membrane foulants in drinking water treatment: Identification by principal component analysis of fluorescence EEM and mitigation by biofiltration pretreatment. Water Research 45, 5161-5170. https://doi.org/10.1016/j.watres.2011.07.022

Pereira, M.O., Vieira, M.J., Beleza, V.M., Melo, L.F., 2001. Reduction of biofouling in paper production processes by using a carbamate-based biocide as a retention agent. PULP \& PAPER-CANADA 102, 42-45.

Pérez, M., Torrades, F., García-Hortal, J.A., Domènech, X., Peral, J., 2002. Removal of organic contaminants in paper pulp treatment effluents under Fenton and photoFenton conditions. Applied Catalysis B: Environmental 36, 63-74. https://doi.org/10.1016/S0926-3373(01)00281-8 
Pokhrel, D., Viraraghavan, T., 2004. Treatment of pulp and paper mill wastewater-a review. Science of The Total Environment 333, 37-58. https://doi.org/10.1016/j.scitotenv.2004.05.017

Pourjafar, S., Jahanshahi, M., Rahimpour, A., 2013. Optimization of TiO2 modified poly(vinyl alcohol) thin film composite nanofiltration membranes using Taguchi method. Desalination 315, 107-114. https://doi.org/10.1016/..desal.2012.08.029

Puro, L., Kallioinen, M., Mänttäri, M., Natarajan, G., C. Cameron, D., Nyström, M., 2010. Performance of RC and PES ultrafiltration membranes in filtration of pulp mill process waters. Desalination 264, 249-255. https://doi.org/10.1016/j.desal.2010.06.034

Puro, L., Kallioinen, M., Mänttäri, M., Nyström, M., 2011. Evaluation of behavior and fouling potential of wood extractives in ultrafiltration of pulp and paper mill process water. Journal of Membrane Science 368, 150-158. https://doi.org/10.1016/..memsci.2010.11.032

Puro, L., Tanninen, J., Nyström, M., 2002. Analyses of organic foulants in membranes fouled by pulp and paper mill effluent using solid-liquid extraction. Desalination 143, 1-9. https://doi.org/10.1016/S0011-9164(02)00215-1

Rajkumar, K., 2016. An Evaluation of Biological Approach for the Effluent Treatment of Paper Boards Industry - An Economic Perspective. Journal of Bioremediation \& Biodegradation 7. https://doi.org/10.4172/2155-6199.1000366

Reyhani, A., Sepehrinia, K., Shahabadi, S.M.S., Rekabdar, F., Gheshlaghi, A., 2015. Optimization of operating conditions in ultrafiltration process for produced water treatment via Taguchi methodology. Desalination and Water Treatment 54, 2669 2680. https://doi.org/10.1080/19443994.2014.904821

Rezvanpour, A., Roostaazad, R., Hesampour, M., Nyström, M., Ghotbi, C., 2009. Effective factors in the treatment of kerosene-water emulsion by using UF membranes. Journal of Hazardous Materials 161, 1216-1224. https://doi.org/10.1016/j.jhazmat.2008.04.074

Salahi, A., Abbasi, M., Mohammadi, T., 2010. Permeate flux decline during UF of oily wastewater: Experimental and modeling. Desalination 251, 153-160. https://doi.org/10.1016/j.desal.2009.08.006 
Sanaei, P., Cummings, L.J., 2017. Flow and fouling in membrane filters: effects of membrane morphology. Journal of Fluid Mechanics 818, 744-771. https://doi.org/10.1017/jfm.2017.102

Saranya, R., Arthanareeswaran, G., Ismail, A.F., 2019. Enhancement of anti-fouling properties during the treatment of paper mill effluent using functionalized zeolite and activated carbon nanomaterials based ultrafiltration. Journal of Chemical Technology \& Biotechnology 94, 2805-2815. https://doi.org/10.1002/jctb.6020

Scholes, E., Brook Carter, P.T., Verheyen, T.V., 2019. Colloidal carbon interference in the treatability of pulp and paper wastewater by MBR. Journal of Environmental Chemical Engineering 7, 102943. https://doi.org/10.1016/j.jece.2019.102943

Sevimli, M., 2005. Post-Treatment of Pulp and Paper Industry Wastewater by Advanced Oxidation Processes. Ozone-science \& Engineering - OZONE-SCI ENG 27, 37-43. https://doi.org/10.1080/01919510590908968

Shankar, R., Singh, L., Mondal, P., Chand, S., 2014. Removal of COD, TOC, and color from pulp and paper industry wastewater through electrocoagulation. Desalination and Water Treatment 52, 7711-7722. https://doi.org/10.1080/19443994.2013.831782

Sharma, N., Bhardwaj, N.K., Singh, R.B.P., 2020. Environmental issues of pulp bleaching and prospects of peracetic acid pulp bleaching: A review. Journal of Cleaner Production 256, 120338. https://doi.org/10.1016/j.jclepro.2020.120338

Singh, A.K., Chandra, R., 2019. Pollutants released from the pulp paper industry: Aquatic toxicity and their health hazards. Aquatic Toxicology 211, 202-216. https://doi.org/10.1016/j.aquatox.2019.04.007

Suhr, M., Klein, G., Kourti, I., Gonzalo, M.R., Santonja, G.G., Roudier, S., Sancho, L.D., 2015. Best Available Techniques (BAT) Reference Document for the Production of Pulp, Paper and Board 906.

Temmink, H., Grolle, K., 2005. Tertiary activated carbon treatment of paper and board industry wastewater. Bioresource Technology 96, 1683-1689. https://doi.org/10.1016/j.biortech.2004.12.035

Thuvander, J., Lipnizki, F., Jönsson, A.-S., 2019. On-Site Recovery of Hemicelluloses from Thermomechanical Pulp Mill Process Water by Microfiltration and 
Ultrafiltration. Journal of Wood Chemistry and Technology 39, 214-223. https://doi.org/10.1080/02773813.2019.1565865

Tiku, D.K., Kumar, A., Sawhney, S., Singh, V.P., Kumar, R., 2007. Effectiveness of Treatment Technologies for Wastewater Pollution Generated by Indian Pulp Mills. Environ Monit Assess 132, 453-466. https://doi.org/10.1007/s10661-006-9548-3

Van Beukering, P.J.H., Bouman, M.N., 2001. Empirical Evidence on Recycling and Trade of Paper and Lead in Developed and Developing Countries. World Development 29, 1717-1737. https://doi.org/10.1016/S0305-750X(01)00065-1

Wang, Z., Wu, Z., Yin, X., Tian, L., 2008. Membrane fouling in a submerged membrane bioreactor (MBR) under sub-critical flux operation: Membrane foulant and gel layer characterization. Journal of Membrane Science 325, 238-244. https://doi.org/10.1016/j.memsci.2008.07.035

Xu, Y., Li, Y., Hou, Y., 2019. Reducing ultrafiltration membrane fouling du ring recycled paper mill wastewater treatment using pretreatment technologies: a comparison between coagulation and Fenton. Journal of Chemical Technology \& Biotechnology 94, 804-811. https://doi.org/10.1002/jctb.5826

Yang, S., Li, W., Zhang, H., Wen, Y., Ni, Y., 2019. Treatment of paper mill wastewater using a composite inorganic coagulant prepared from steel mill waste pickling liquor. Separation and Purification Technology 209, 238-245. https://doi.org/10.1016/j.seppur.2018.07.049

Yu, H., Qu, F., Liang, H., Han, Z., Ma, J., Shao, S., Chang, H., Li, G., 2014. Understanding ultrafiltration membrane fouling by extracellular organic matter of Microcystis aeruginosa using fluorescence excitation-emission matrix coupled with parallel factor analysis. Desalination 337, 67-75. https://doi.org/10.1016/j.desal.2014.01.014

Yuan, G., Dai, H., Ye, C., Zhang, Y., Wang, Z., 2011. ADSORPTION OF Ca(II) FROM AQUEOUS SOLUTION ONTO CELLULOSIC FIBERS AND ITS IMPACT ON THE PAPERMAKING PROCESS. BioResources 6, 2790-2804-2804. https://doi.org/10.15376/biores.6.3.2790-2804

Z. Wang, Z., Wu, Z., Tang, S., 2009. Characterization of dissolved organic matter in a submerged membrane bioreactor by using three-dimensional excitation and 
emission matrix fluorescence spectroscopy. Water Research 43, 1533-1540. https://doi.org/10.1016/j.watres.2008.12.033

Zaidi, A., Buisson, H., Sourirajan, S., Wood, H., 1992. Ultra- and Nano-Filtration in Advanced Effluent Treatment Schemes for Pollution Control in the Pulp and Paper Industry. Water Science and Technology 25, 263-276. https://doi.org/10.2166/wst.1992.0254

Zhang, Q., Chuang, K.T., 2001. Adsorption of organic pollutants from effluents of a Kraft pulp mill on activated carbon and polymer resin. Advances in Environmental Research 5, 251-258. https://doi.org/10.1016/S1093-0191(00)00059-9

Zwain, H.M., Hassan, S.R., Zaman, N.Q., Aziz, H.A., Dahlan, I., 2013. The start-up performance of modified anaerobic baffled reactor (MABR) for the treatment of recycled paper mill wastewater. Journal of Environmental Chemical Engineering 1, 61-64. https://doi.org/10.1016/j.jece.2013.03.007 
2 CHAPTER: LITERATURE REVIEW 


\subsection{Pulp-and-paper mill manufacturing}

The pulp and paper (P\&P) industry is ranked as the world's third largest consumer of fresh water (Rajkumar, 2016; Sevimli, 2005) and an important producer of wastewater and differentorganic and inorganic contaminants (Mandeep et al., 2020). Although the water consumed in the paper mill industry has been reduced in the last decade, its requires huge amount, evaluated in the range of $\left(\sim 50-60 \mathrm{~m}^{3}\right.$ of water to produce 1 ton of paper) of paper produced (Pizzichini et al., 2005; Ram et al., 2020). Moreover, High fresh water consumption and the accumulation of contaminants during the paper manufacturing process contribute to the large volume of effluent from paper mills (Haq and Raj, 2020).

Paper and cardboard manufacturing are produced from virgin or recovered fibers $(R C F)$ as raw materials. Chemical and mechanical techniques (chemical pulping (CP), chemo-mechanical pulping (CMP), and chemical thermo-mechanical pulping (CTMP), or a combination of them can be used to pulp producing processes from virgin raw materials (Kamaliand Khodaparast, 2015a), whereas recovered pulp is produced from RCF processes such as waste papers (mixed office waste, old news print and, old cardboard and corrugated container).

Process manufacturing of pulp and papermaking comprises a series of stages, generally divided into three steps:

- Pulp making;

- Pulp processing (pasta preparation) and ;

- Paper-making.

All of theses processes are consumers of fresh water and producer of a large amount of wastewater with special characteristics and contaminants. Therefore, in order to a better understand all the problems suffered by the paper industry, regarding to the effluent contaminants, it is essential to know the pulp and paper manufacturing process. Figure 2-1 shows a schematic diagram of the paper production process. 


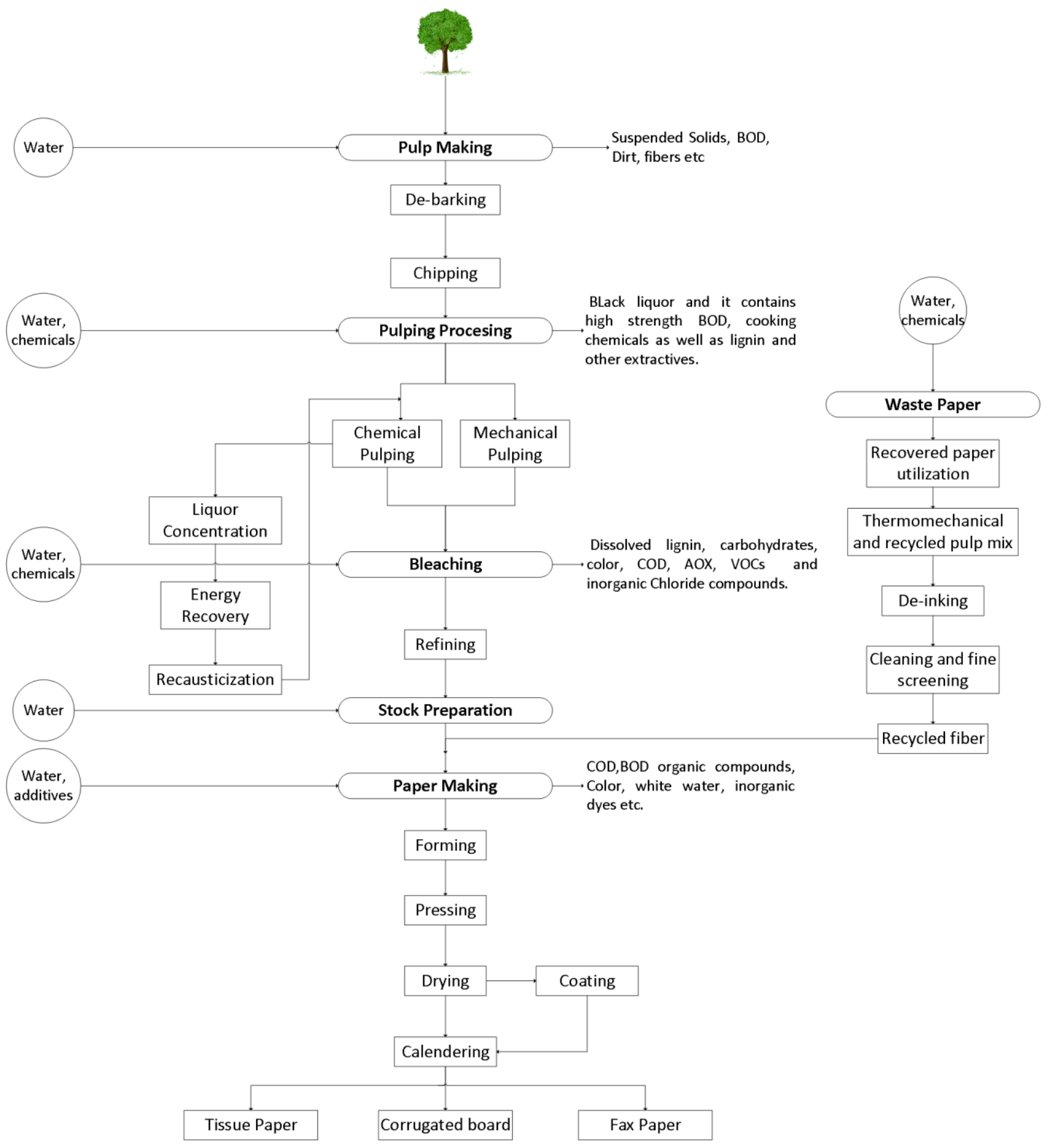

Figure 2-1 - Schematic illustration of the pulp and paper process.

\subsubsection{Pulp making}

Manufacturing of pulp starts with raw material or RCF preparation. Therefore, pulping is the process used to separate lignin and hemicelluloses from cellulose, it is to say, separate differentfibres in the wood used for making paper (Hendriks, 2007). In the case that wood (virgin fiber) is used as raw materials, the wood pieces are cooked at high temperature and under high pressure. Mechanical, chemical and chemimechanical techniques such as, mechanical pulping (MP), thermo-mechanical pulping 
(TMP), kraft (sulfate) and sulfite processes and, chemical thermo-mechanical pulping (CTMP) can be employs for the pulp making for paper and cardboard production (Avşar and Demirer, 2008).

Moreover, pulping process applied in paper production from RCF recycling is generally used to convert mixed waste paper into the recovered fibers dispersed in water and to prepare them for removes the ink particles from cellulose fibers and responsible for the removal of large particles with high and medium density (Kamali and Khodaparast, 2015a).

\subsubsection{Pulp processing}

After pulp making, pulp is processed to remove impurities by screening, defibering and deknotting, besides to recycles any residual cooking liquor via pulp washing process (Bajpai, 2012). An efficient washing is critical to maximize return of cooking liquor to chemical recovery and to minimize carryover of cooking liquor into the bleach plant, because excess cooking liquor increases consumption of bleaching chemicals.

Moreover, before pulp can be made into paper, the pulp is prepared for the paper machine this step including the blending of different pulps, dilution, refining and the addition of chemical additives. Another important step for pulp processing is called stock preparation (fiber disintegration, blending of fiber, cleaning, fiber modification, and storage and mixing) conducted to convert raw stock into furnish for the paper machine essential to determine the properties of the paper - making.

\subsubsection{Paper-making}

The final stage of paper manufacturing is the paper-making, in which the processed pulp is combined with some materials including dyes, resins, fillers such as clay, titanium dioxide, calcium carbonate, and sizing agents like rosin and starch, to form the paper (Kamali and Khodaparast, 2015a).

Paper consists of a web of pulp fibers, usually formed from an aqueous slurry (approximately $99.5 \%$ water and approximately $0.5 \%$ pulp fiber) on a wire or screen, and held together by hydrogen bonding. The paper machine involves either distinct sections. The steps are: forming (applying the pulp slurry to a screen), draining (allowing water to drain by means of a force such as gravity or a pressure difference developed by a water column), pressing (further dewatering by squeezing water from 
the sheet), and drying (air drying or drying of the sheet over a hot surface) (Bajpai, 2015, 2012; Verband Papierfabriken, 2017).

At the end of the paper machine, paper continues onto a reel for winding to the desired roll diameter. The machine tender cuts the paper at this diameter and immediately starts a new reel with the additional paper falling as an endless web (Ashrafi et al., 2015). Paperboard and Corrugated board are made in a similar way to paper but is thicker to protect materials or products (foods) from mechanical damage. The both has an outer and an inner lining of kraft paper (made from at least $80 \%$ sulfate pulp) with a central corrugating (or fluting) material. This is made by softening kraftpaperboard with steam and passing it over corrugating rollers (Kirwan, 2011).

It is worth mentioning, this study is focus on a recycling paper and corrugated cardboard manufacturing produced by recovered fibers from recycled papers.

\subsection{Effluent characteristics from Paper industry}

P\&P manufacturing generally produce a large amount of effluents that contain various organic and inorganics amounts of pollutants (Kamali et al., 2016; Ram et al., 2020). The characteristics of the generated effluents are mainly affected by the degree of contamination and characteristics of raw material, the additives that are used for dispersing the fibers, removing ink, and bleaching, and bleaching percentage of virgin pulp or RCFs used in paper making, the chemicals used on process, degree of water conservation and percentage of water reuse (EISergany et al., 2015; Kamali et al., 2016; Miranda Carreño et al., 2009; Monte et al., 2009; Muhamad et al., 2012).

This effluent contains a high biodegradable organic matter loading such as chemical oxygen demand (COD), biochemical oxygen demand (BOD), absorbable organic halides (AOX), and high concentrations of total suspended solids and floating matters (Ashrafi et al., 2015; Hubbe et al., 2016; Nuortila-Jokinen, 2000; Nuortila-Jokinen et al., 2004), besides of significant quantities of fibre (losses with effluent $0.5-5 \%$ of total fibre amount), filler, fines, color and VOCs and other wet-end additives (Pokhrel and Viraraghavan, 2004).

Another specific pollutant in paper mill effluent is the considerable accumulation of DCS such as resins and fatty acids, residual lignin, hemicelluloses and electrolytes (especially $\mathrm{Ca}^{2+}$ and $\mathrm{Mg}^{2+}$ ) presents in pulp suspension and white water (Chen et al., 2015a; Hubbe et al., 2012; Ordóñez et al., 2010; Yuan et al., 2011). The DCS can be 
defined as the sum of the organic matter, polyelectrolytes, other dissolved material, and suspended particles (less than $1 \mu \mathrm{m}$ ) presentin process water or paper mill effluent (Chen et al., 2015a), mainly come from fiber extractives (virgin fiber or RCF) and the chemical additives during paper manufacturing process. Furthermore, it was reported by Chen et al. (2015) that the multivalentmetal ions, especially $\mathrm{Ca}^{2+}$, can easily disturb the stability of DCS via a Ca-DCS complex and aggregate formation, causing serious affects on the papermaking operations, effluentreutilization and quality of the resulting paper products. The pollutants at various stages of the pulping and paper making process are presented in Figure 2-1.

\subsection{Wastewater treatment in paper industry}

Several physical, chemical, biological and integrated treatment processes for paper mill effluent have been widely applied to comply with the stringent environmental regulations, improve the quality of the effluents and consequently water reuse. The treatments including coagulation and flocculation (Ahmad et al., 2008), sedimentation (Bhattacharjee et al., 2007), adsorption (Temmink and Grolle, 2005), advanced oxidation (Catalkaya and Kargi, 2008; Pérez et al., 2002), Ozonation (Mänttäri et al., 1997), membrane filtration (Gönder et al., 2012; Liua et al., 2004; Nuortila-Jokinen et al., 2004; Puro et al., 2010; Zaidi et al., 1992), activated sludge (Assalin et al., 2009; Diez et al., 2002) and upflow anaerobic filter (Ali et al., 2013; Arshad et al., 2011).

The classical wastewater treatment plant (WWTP) in paper factories are composed for primary treatment (pre-treatment) followed by biological (secondary) and tertiary treatment, respectively (Gupta and Gupta, 2019; Kamali and Khodaparast, 2015a). A simplified process flowsheet of the WWTP used for the paper mill effluent is shown in Figure 2-2. Effluent treatment plant consists of:

- Primary treatment in WWTP on the paper factory could have a positive impact to remove fibers and suspended solids from the effluent (Xu et al., 2019), generally this task use sedimentation or floatation tank (based on a physical removal of solids)

- Biological (secondary) treatment unit (aerobic and/or anaerobic processes) to remove organic contaminants (dissolved and colloidal compounds) in wastewaters and; 
- Tertiary treatment used for effluent polishing and elimination of more advanced constituents, in order to produce water of a quality suitable for recycling to mill processes.

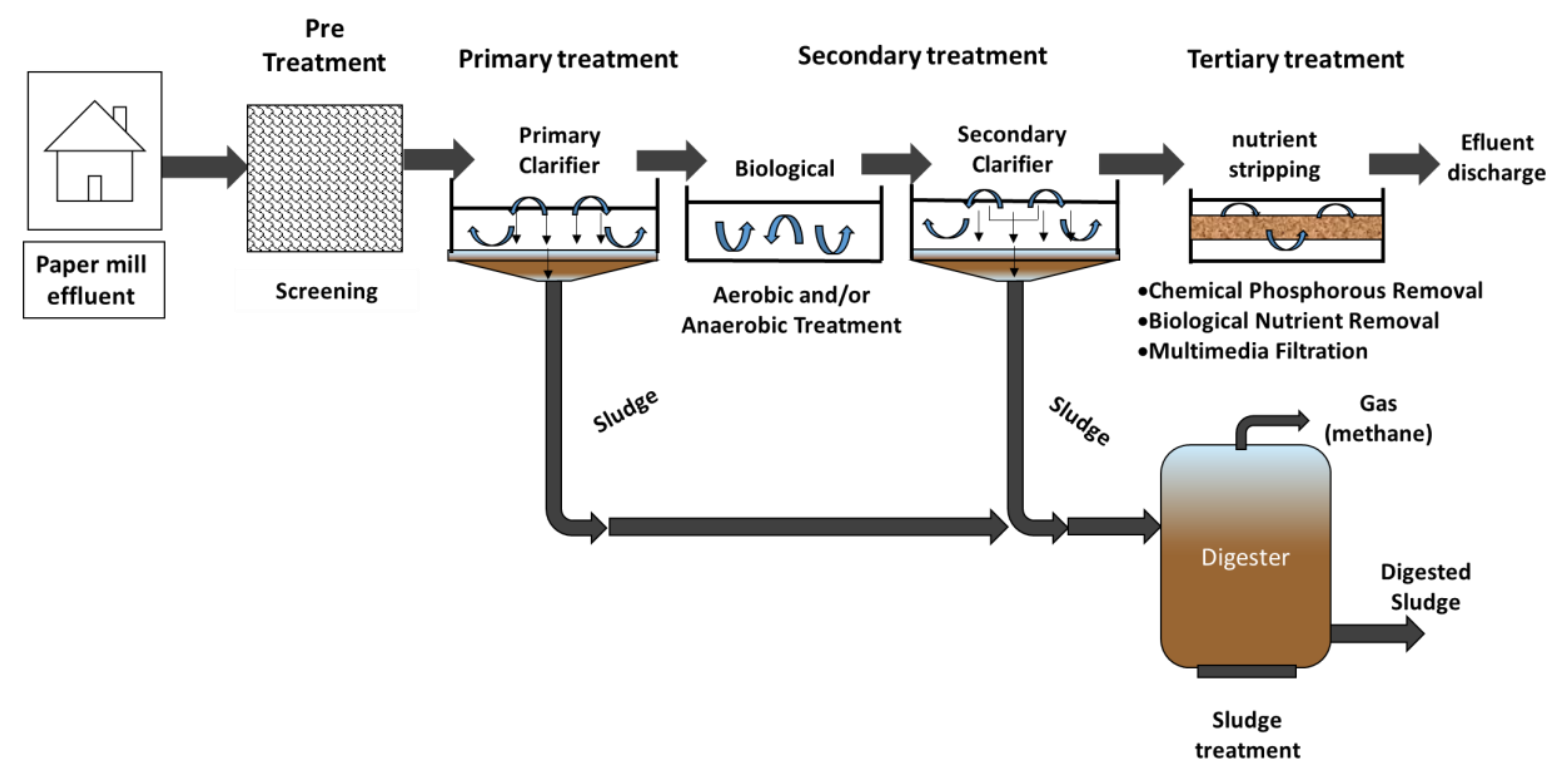

Figure 2-2 - Typical layout of paper mill effluent treatment plant (Thompson et al., 2001).

\subsubsection{Primary / physical treatment}

The primary treatment process includes either sedimentation or floatation. According previous studies carried out by EISergany et al. (2015) in paper mill effluent treatment the sedimentation process is much preferred over the floatation which give a high percentage of suspended solids removal. Saunamaki. (1997) and Thompson et al.(2001) reported the possibility of removing $80 \%$ of suspended matters from wastewater by sedimentation. (Bhattacharjee et al., 2007) used sedimentation combined with adsorption and ultra-filtration for the treatment of Kraft black liquor and achieved $60 \%$ and $87 \%$ total solid removal, respectively. In addction, it is woth metioning that chemicals such as alum or polymer may be added to enhance the sedimentation process (EISergany et al., 2015).

\subsubsection{Secondary treatment}

As paper mill effluents are biodegradable organic matter, expressed as chemical and biological oxygen demands (COD/BOD) ratios between 2 and 2.5, they can be removed by biological treatment (Kamali and Khodaparast, 2015a; Thompson et al., 2001), however, the amountof organic matter sometimes is so high that conventional biological reactors (normally consists of an activated sludge process or anaerobic digestion) is limited. Therefore, a possible way to overcome the problem consists in a 
combination of both biological stages (aerobic and anaerobic), starting with an anaerobic treatment and finishing with an aerobic process (Thompson et al., 2001).

\subsubsection{Aerobic Treatment}

Aerobic microorganisms require oxygen to support their metabolic activity and the oxygen is supplied in the form of air by aeration equipment, being that one of the main objectives of aerated biological treatment is to reduce the COD and BOD levels of the treated wastewater. Therefore, several aerobic treatment processes are generally applied to treat paper mill wastewater (due their ease of operation, relatively low capital and operating costs (Ashrafi et al., 2015), such as aerated lagoons or aerated stabilization basins (ASB), Submerged membrane bioreactors (sMBR), activated carbon biofilm reactor (ACBR), sequencing batch reactor (SBR) and activated sludge (AS). Table 2-1, shows the removal efficiency of different types of aerobic treatment processes applied in pulp-and-paper wastewaters.

Moreover, in the recently reviewed carried out by Kamali and Khodaparast. (2015a) shows that conventional and modified forms of AS process has been the major treatment method for paper mill effluents, due the economic considerations and efficiency to reduce the COD, BOD, and AOX (Hubbe et al., 2016).

Assalin et al. (2009) used AS to remove COD, TOC, total phenols and color from kraft effluentin a paper mill, the removal efficiency obtained were 75.5, 59.1, 77 and 52.3\%, respectively. Thompson and Forster. (2003) used AS to remove COD from different pulp-and-paper wastewaters in a laboratory-scale plant. The basic principle of the active sludge can be seen in Figure 2-3.

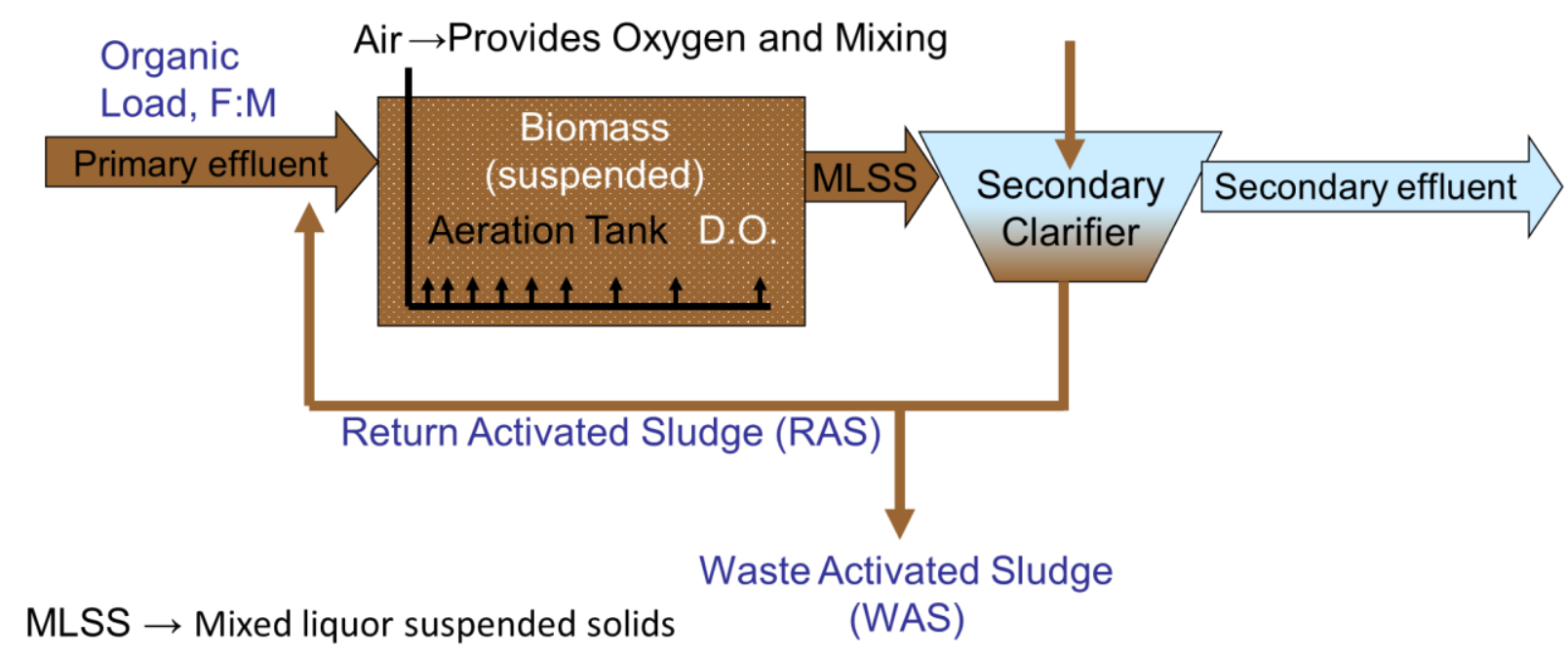

Figure 2-3 - Basic principle of the active sludge process. 
Table 2-1- Removal efficiency of different aerobic treatment processes applied in pulp-andpaper wastewaters. Adopted from (Ashrafi et al., 2015).

\begin{tabular}{|c|c|c|c|c|c|c|}
\hline \multirow{2}{*}{$\begin{array}{l}\text { Treatment } \\
\text { process }\end{array}$} & \multirow{2}{*}{$\begin{array}{c}\text { Wastewater } \\
\text { generated }\end{array}$} & \multicolumn{4}{|c|}{ Contaminants removal efficiency (\%) } & \multirow[t]{2}{*}{ References } \\
\hline & & COD & $\mathrm{BOD}_{5}$ & Color & Other compounds & \\
\hline \multirow[t]{4}{*}{$\overline{A S S}$} & Paper mill & 75.5 & 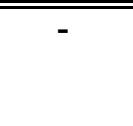 & $\overline{777}$ & $\begin{array}{c}59.1 \text { (TOC), } 52.3 \text { (total } \\
\text { phenols) }\end{array}$ & $\begin{array}{c}\text { (Assalin et al., } \\
\text { 2009) }\end{array}$ \\
\hline & $\begin{array}{l}\text { Kraft pulp } \\
\text { mil }\end{array}$ & 60 & 90 & 40 & 36 (Tannin and Lignin) & $\begin{array}{l}\text { (Diez et al., } \\
\text { 2002) }\end{array}$ \\
\hline & P\&P mill & 95 & 98 & 97.5 & 97 (TSS) & $\begin{array}{l}\text { (Ghoreishi and } \\
\text { Haghighi, 2007) }\end{array}$ \\
\hline & $\begin{array}{l}\text { Kraft pulp } \\
\text { mill }\end{array}$ & 60 & 98 & 21.1 & (11.1) total phenolic & $\begin{array}{c}\text { (Xavier et al., } \\
\text { 2011) }\end{array}$ \\
\hline \multirow[t]{2}{*}{ MBR } & Paper mill & 98 & - & - & $\begin{array}{c}92.99\left(\mathrm{NH}_{3}-\mathrm{N}\right), 96.36 \\
\text { (Total phosphorus), } \\
\operatorname{SMP}(66.2)\end{array}$ & $\begin{array}{l}\text { (Erkan and } \\
\text { Engin, 2017) }\end{array}$ \\
\hline & Paper mill & 92 & $>98$ & - & $\begin{array}{c}84 \text { (Ammonia), >99 } \\
\text { (TSS) }\end{array}$ & $\begin{array}{l}\text { (Zhang et al., } \\
\text { 2009) }\end{array}$ \\
\hline \multirow[t]{3}{*}{$\begin{array}{l}\text { Aerated } \\
\text { lagoons }\end{array}$} & Paper mill & 38.5 & 40.7 & - & $66.1 \%(S S)$ & $\begin{array}{c}\text { (Fathallah et al., } \\
\text { 2014) }\end{array}$ \\
\hline & P\&P mill & $\begin{array}{l}60- \\
70\end{array}$ & 97 & $>95$ & $\begin{array}{c}\text { (50) AOX, } 85 \\
\text { (chlorinated phenolics) }\end{array}$ & $\begin{array}{l}\text { (Pokhrel and } \\
\text { Viraraghavan, } \\
\text { 2004) }\end{array}$ \\
\hline & P\&P mill & 67 & 90 & - & - & (Bryant, 2010) \\
\hline SBR & $P \& P$ mill & 84 & 83 & - & 85 (TDS), 88 (TSS) & $\begin{array}{c}\text { (Kumar R and } \\
\text { K, 2014) }\end{array}$ \\
\hline AGS & P\&P mill & 79 & - & - & 56 (tannin/lignin) & $\begin{array}{l}\text { (Vashi et al., } \\
\text { 2019) }\end{array}$ \\
\hline * Total & hosphorus (T & & & & & \\
\hline * Solu & microbial pr & lucts & & & & \\
\hline$*$ Susp & ds & & & & & \\
\hline
\end{tabular}

In Figure 2-3 the wastewater is treated in two steps: aeration and sedimentation. In the first step, wastewater is treated with a high concentration of microorganism and a powerful aeration, and the retention time can vary between a couple of hou rs and up to a day. In the second step water and sludge is separated in a sedimentation basin and parts of the sludge is pumped back to the aeration basin. The recirculation of sludge enables a high concentration of microorganisms which is of importance for extensive reduction in organic material. 
The removal of biodegradable organic substances, both soluble and finely dispersed is accomplished by biological oxidation with the help of a microbial consortium. The ecology of microbial species, in activated sludge process is having the significant role in the bio-oxidation and subsequent clarification. The activated sludge process works well as long as the consortia of microorganisms, typically termed as sludge, grows in a healthy way, and settles and compacts in the secondary settling tank. Nevertheless, single conventional aerobic methods such as active sludge are not effective in degradation of the compounds such as dissolved lignin, unsaturated fatty and resin acids mainly because of their size and complex structure, and therefore, a possible way to overcome the problem consists in a combination of aerobic processes with physicochemical and anaerobic methods (Thompson et al., 2001).

\subsubsection{Anaerobic Treatment}

Anaerobic treatment is a treatment without presence of oxygen and has proven to be a stable process for treatment of high strength wastewaters. Effluents originated from recycled paper mill are often treated anaerobic, although, this technology is not used as widely as the aerobic treatments in the pulp and paper industry (Subashini, 2015). One of the major problems with implementation of anaerobic treatment for paper mill effluents is the potential for hydrogen sulphide formation, since sulphate is widely used as active cooking chemical in many pulp and paper mills. Another important issue with an anaerobic process is its sensitivity of anaerobic bacteria to toxic compounds present in the wastewater (Thompson et al., 2001). However, anaerobic treatment has many advantages over aerobic treatment such as low energy input, produce less amount of sludge, comparatively fewer nutrients are requiring, lower chemical consumption, small environmental footprint and energy production in the form of biogas (Chen et al., 2003; Nilsson, 2007; Persson, 2011) .

There are several different types of digestion system for anaerobic degradation of pepper mill effluent such as upflow anaerobic sludge blanket (UASB), up-flow anaerobic filter (UAF), anaerobic membrane bioreactor (AnMBR), fluidized-bed reactor (FBR), anaerobic baffled reactors (ABR), Anaerobic sequencing batch biofilm reactor (AnSBBR) and anaerobic lagoon (Ashrafi et al., 2015; Bajpai, 2000; Cai et al., 2019; Hubbe et al., 2016; Thompson et al., 2001; Zwain et al., 2013). Table 2-2, presents the removal efficiency of different types of anaerobic treatment processes applied in pulpand-paper wastewaters. 
Table 2-2 - Removal efficiency of different anaerobic treatment processes applied in pulp-andpaper wastewaters. Adopted from (Ashrafi et al., 2015).

\begin{tabular}{|c|c|c|c|c|c|c|}
\hline \multirow{2}{*}{$\begin{array}{l}\text { Treatment } \\
\text { process }\end{array}$} & \multirow{2}{*}{$\begin{array}{c}\text { Wastewater } \\
\text { generated }\end{array}$} & \multicolumn{4}{|c|}{ "Contaminants removal efficiency (\%) } & \multirow[t]{2}{*}{ References } \\
\hline & & COD & $\mathrm{BOD}_{5}$ & Color & $\begin{array}{c}\text { Other } \\
\text { compounds }\end{array}$ & \\
\hline \multirow{5}{*}{ UASB } & $\overline{\text { Kraft pulp mill }}$ & 76 & - & - & - & $\begin{array}{c}\text { (Buzzini et al., } \\
\text { 2005). }\end{array}$ \\
\hline & Paper mill & 88 & - & - & $72(\mathrm{AOX})$ & $\begin{array}{c}\text { (Arshad et al., } \\
\text { 2011) }\end{array}$ \\
\hline & $\begin{array}{l}\text { Bleaching } \\
\text { effluent }\end{array}$ & 57 & - & - & $\begin{array}{c}55 \text { (TOC), } 31 \\
\text { (Lignin) }\end{array}$ & $\begin{array}{l}\text { (Ali et al., } \\
\text { 2010). }\end{array}$ \\
\hline & Paper mill & 70 & 90 & - & $\begin{array}{c}71-99.7 \\
\text { (chlorinated } \\
\text { organics) }\end{array}$ & $\begin{array}{l}\text { (Mahadevaswa } \\
\text { my et al., } \\
\text { 2004). }\end{array}$ \\
\hline & $\begin{array}{l}\text { Recycled } \\
\text { paper mill }\end{array}$ & 85 & 75.5 & - & 51.2 (MLVSS) & $\begin{array}{l}\text { (Hassana et al., } \\
\text { 2014). }\end{array}$ \\
\hline \multirow[t]{2}{*}{$\mathrm{ABR}$} & $\begin{array}{l}\text { Recycled } \\
\text { paper mill }\end{array}$ & 71 & 71 & - & $\begin{array}{c}32 \text { (volatile fatty } \\
\text { acids) }\end{array}$ & $\begin{array}{l}\text { (Zwain et al., } \\
\text { 2013). }\end{array}$ \\
\hline & Paper mill & 88 & - & 95 & $\begin{array}{c}67 \text { (AOX), } 86 \\
\text { (Lignin), } 63 \\
\text { (Phenol) }\end{array}$ & $\begin{array}{l}\text { (Singh and } \\
\text { Thakur, 2006). }\end{array}$ \\
\hline \multirow[t]{4}{*}{ SBBR } & $\begin{array}{l}\text { Recycled } \\
\text { paper mill }\end{array}$ & $39-81$ & - & - & $\begin{array}{c}\text { 82-100 } \\
\text { (Pentachlorophen) }\end{array}$ & $\begin{array}{l}\text { (Muhamad et } \\
\text { al., 2011). }\end{array}$ \\
\hline & $\begin{array}{l}\text { Bleaching } \\
\text { effluent }\end{array}$ & 50 & 70 & - & $50(\mathrm{AOX})$ & $\begin{array}{c}\text { (Ashrafi et al., } \\
\text { 2015). }\end{array}$ \\
\hline & & & & & & \\
\hline & Cardboard & 46.6 & - & - & - & $\begin{array}{c}\text { (Sopajaree and } \\
\text { Teeratitayangk } \\
\text { ul, 2013). }\end{array}$ \\
\hline
\end{tabular}

However, the preferred type of anaerobic processes used in paper mill industry is the UASB (Möbius and Helble, 2004). Chen and Horan. (1998) studied a UASB reactor to treat newsprint paper mill wastewater to remove COD and sulfite, their achieved $66 \%$ and $73 \%$ removal efficiency, respectively. Arshad et al. (2011) used a UASB reactor to assess feasibility of treatment of paper mill effluent, and was observed the COD and organic halides removal efficiency between $64 \%-88 \%$ and $47 \%-72 \% \%$, respectively. 
Buzzini and Pires. (2007) applied a UASB reactor to treat both bleached and unbleached Kraftmill wastewaters. Their observed higher removal efficiencies of COD and chlorinated organics between $79 \%-82 \%$ and $71 \%-99 \%$, respectively. Nyanchaga and Elkanzi. (2003) investigated the characteristic strength and treatability of a recycled paper mill wastewater in Nairobi, Kenya in a UASB reactor, and achieved about $63 \%$ COD removal. Among the UASB systems the preferred type applied for the treatment of paper mill effluents are IC (internal Circulation) and BIOBED - EGSB rectors (see Figure 2-4 and Figure 2-5).

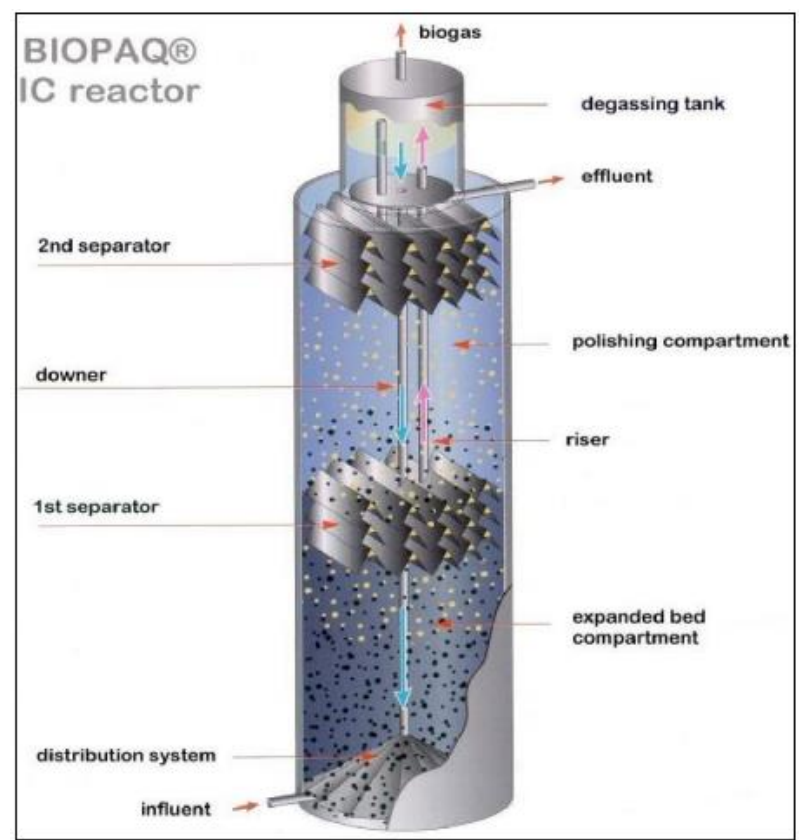

Figure 2-4 - IC (anaerobic reactor @ Paques) for treatment of papermill effluent.

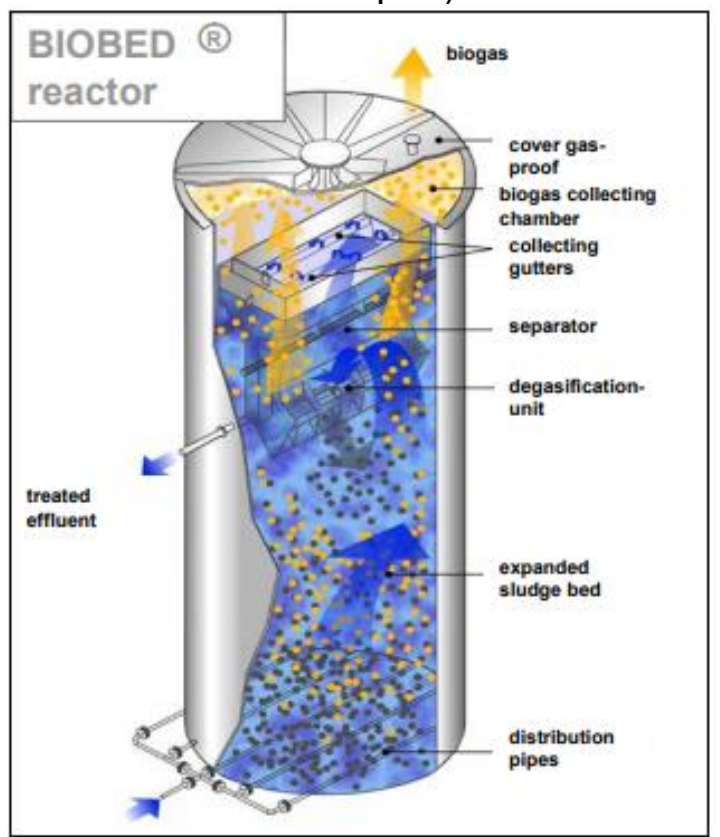

Figure 2-5 - Biobed EGSB anaerobic reactor (@Veolia Water Technologies) for treatment of paper mill effluent. 
The anaerobic reactor process involves biological degradation of organic compounds into different end products including methane (50 - 75\%), carbon dioxide (25 50\%), hydrogen (5 10\%) and nitrogen (12\%) (Kamali et al., 2016), by a consortia of anaerobic bacteria (Yuan et al., 2012). The process offers several advantages and disadvantages over other treatment method. A well managed anaerobic reactor system has the ability to produce maximum $\mathrm{CH}_{4}$ production, and will not discharge any gases to the atmosphere. This system will also provide a source of energy with no net increase in atmospheric carbon which contributes to climate change. Energy generated through the anaerobic digestion process can help reduce the demand for fossil fuels

Advanced oxidation processes (AOPs) have been successfully used to bleach the black effluents from the production of kraft pulp and white paper in substitution of chlorine (Pérez et al., 2002).

\subsubsection{Tertiary treatment}

The effluent from biological treatment can be tertiary treated for further removal of color, suspended solids, COD and DCS in order to produce a clear effluent and recycling the process water (Nuortila-Jokinen et al., 2004). Process units such as ultrafiltration, adsoprtion, ozonation, activated carbon filter, coagulation, electrocoagulation, electroflotation, dissolved air flotation, photon-fenton and wetoxidation are also used to achive maximum treatability performance, to polish the quality of the effluent before its final disposal, to reduce the toxicant concentration in the effluent, to recycling into the process and accordance to the available legislations (Ali et al., 2013). However, few applications of tertiary treatment processes are used in paper mills due their associated high cost (Ashrafi et al., 2015).

\subsection{Membrane filtration fundamentals}

Membrane filtration is a sophisticated unit operations (separation process) by a physical barrier that either completely rejects or reduces the flux of a given compound so that it may be separated from the rest of the feed stream (Sogaard, 2014). In recent years membrane separation has been widely used in several industrial applications such as water purification, chemical, biotechnological,pharmaceutical and food to removal of bacteria, microorganisms, colloids, dissolved and natural organic material, which can impart color, tastes, and odors to water and react with disinfectants to form disinfection byproducts. The particles to be separated are usually large compared to 
the pore size characteristic of the membrane (Sahai, 2000), and the separation is based on exclusion discrimination by physical size, charge or affinity or a combination of these properties. Figure 2-6 describes a situation in which a feed stream is forced through a semipermeable membrane to create a filtrate with a reduced concentration of solutes by size exclusion, where only particles smaller than the membrane pores through the membrane.

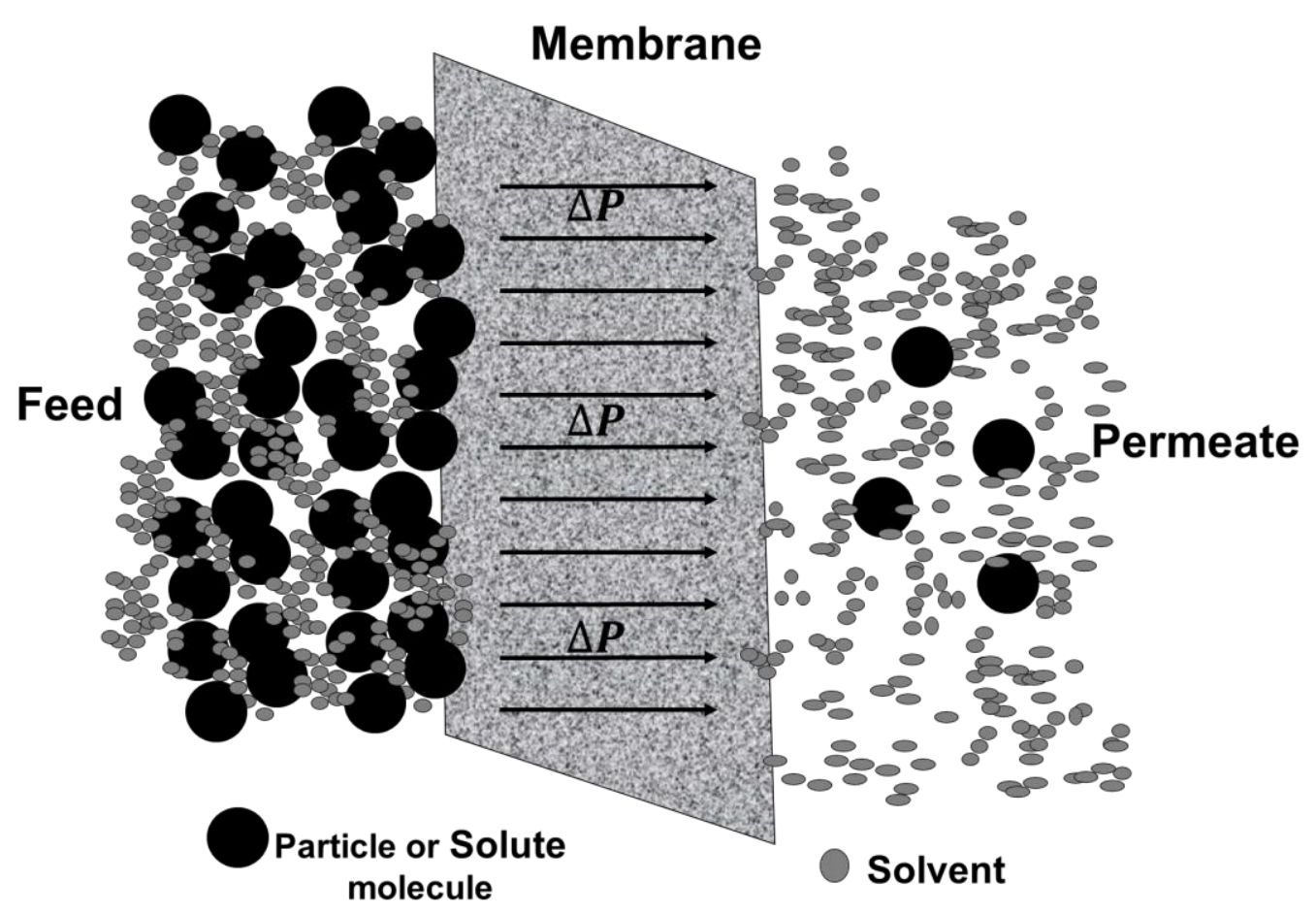

Figure 2-6 - membrane separation by size exclusion.

As mentioned previously, the primary effect governing membrane filtration is size exclusion, and membranes are currently available into four main groups reverse osmosis (RO), nanofiltration (NF), ultrafiltration (UF), and microfiltration (MF) membranes, which are classified according to the nominal size of the pore (Percival et al., 2013). All theses four types of membranes are in the same category based on their applied driving force (pressure difference through the membrane). The range of membrane filtration processes is summarized in Table 2-3 and Figure 2-7.

Reverse Osmosis, are typically applied for desalination, specific contaminants removal such as nitrates, arsenic, pesticides, radionuclides, water reuse, and ultra pure water production. Reverse osmosis membrane has a pore diameter less than $0.001 \mu \mathrm{m}$ (nonporous membrane) and it is been designed to retain the salts, sugars and low molecular weight compounds. 
Nanofiltration is a porous membrane, with a pore diameter ranges from $0.001 \mu \mathrm{m}$ to $0.01 \mu \mathrm{m}$ (nominally 5 nanometer), and is applied for removal for removal of the multivalentions from water (i.e. removal of $\mathrm{Ca}^{2+}$ and $\mathrm{Mg}^{2+}$ ), heavy metals and dissolved organic matter removal.

A typical Ultrafiltration membrane, has a nominally pore diameters between $0.01 \mu \mathrm{m}$ to $0.1 \mu \mathrm{m}$. However, UF membranes are typically categorized based on their molecular weight cut off (MWCO) rather in terms of particular pore size (Scott, 1995). MWCO is defined on the basis of $90 \%$ rejection of a solute with a particular molecular weight. UF membranes can be applied for different applications such as viruses and colloid removal, clarifying juice, and beer, for removal of microorganisms, protozoa, bacteria, suspended solids and collids in water treatment (Figoli and Criscuoli, 2017; Pendergast and Hoek, 2011).

Microfiltration membrane has a pore diameter size ranges from 0.1 to $1.0 \mu \mathrm{m}$ (nominally $0.1 \mu \mathrm{m}$ ), is often placed prior to other membranes (UF, NF, RO) to retain small particles, and it's been designed for clarification of water and wastewater.

Table 2-3 -Classification of membrane Mulder processes with pore size and pressure-drive (adapted from Mulder, 1996).

\begin{tabular}{|c|c|c|c|c|c|}
\hline $\begin{array}{c}\text { Membrane } \\
\text { process }\end{array}$ & $\begin{array}{l}\text { Separation } \\
\text { principle }\end{array}$ & $\begin{array}{c}\text { Pore Size } \\
(\mathrm{nm})\end{array}$ & $\begin{array}{c}\text { MWCO } \\
\text { (Da) }\end{array}$ & $\begin{array}{l}\text { Operating } \\
\text { pressure } \\
\text { (bar) }\end{array}$ & Rejected species \\
\hline$\overline{\mathrm{MF}}$ & 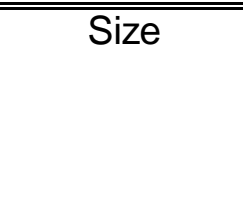 & "100-1000 & - & $0.1-2$ & $\begin{array}{c}\text { Bacteria, cysts, } \\
\text { spores and } \\
\text { polymers }\end{array}$ \\
\hline UF & Size, charge & 10-100 & $>1000$ & $0.1-3$ & $\begin{array}{l}\text { Proteins, viruses, } \\
\text { endotoxins, } \\
\text { pyrogens and } \\
\text { colloids }\end{array}$ \\
\hline NF & $\begin{array}{c}\text { Size, charge, } \\
\text { affinity }\end{array}$ & $1-10$ & $200-1000$ & $4-20$ & $\begin{array}{c}\text { Sugars, pesticides } \\
\text { and micropollutant } \\
\text { removal }\end{array}$ \\
\hline RO & $\begin{array}{c}\text { Size, charge, } \\
\text { affinity }\end{array}$ & $0.1-1$ & $<200$ & $10-60$ & $\begin{array}{l}\text { Salts, sugars and } \\
\text { low molecular } \\
\text { weight compounds }\end{array}$ \\
\hline
\end{tabular}




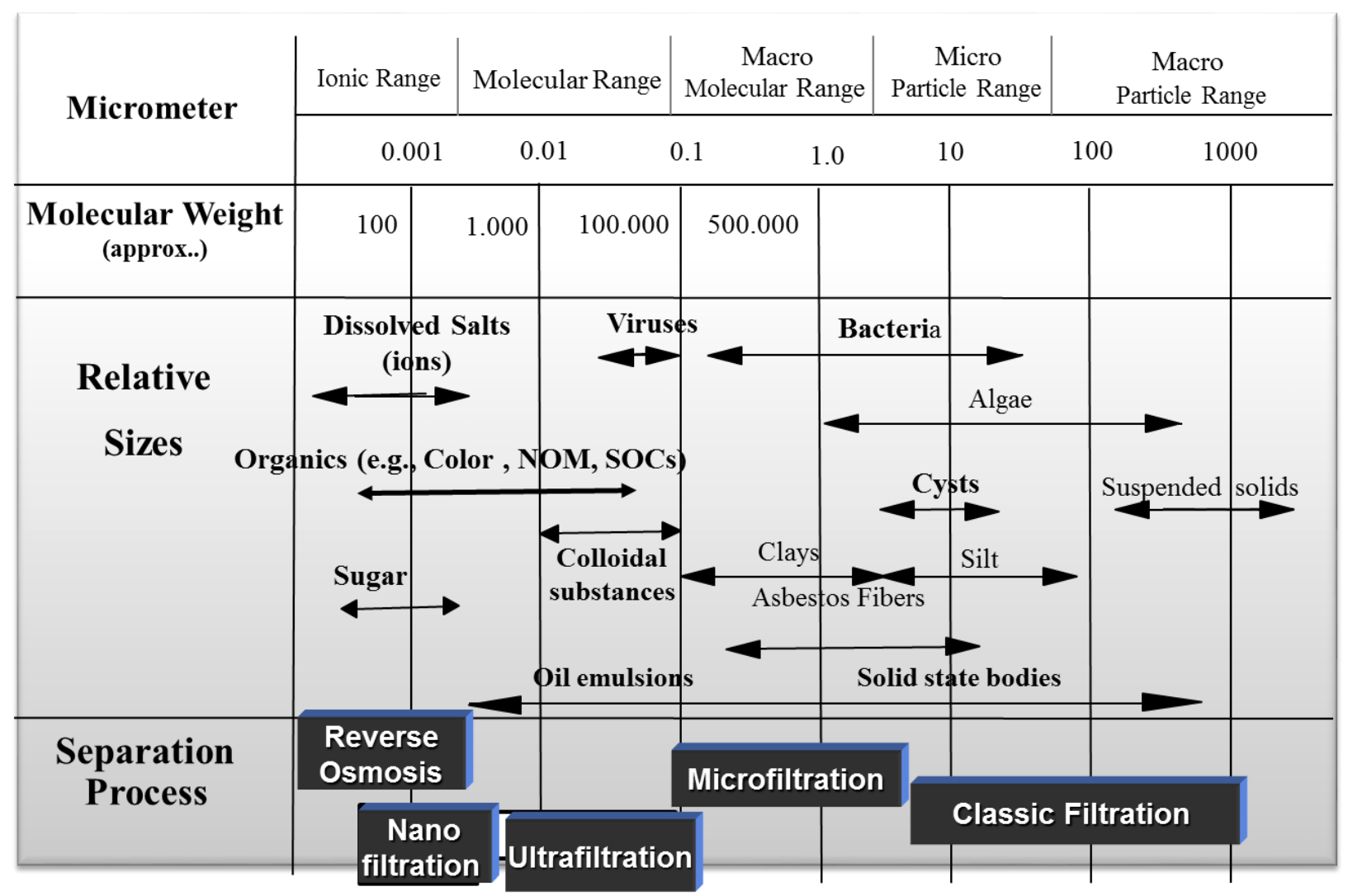

Figure 2-7 - Spectrum of membrane filtration. Addapted from Graff, 2012).

\subsubsection{Ultrafiltration membrane process}

As mentioned above, ultrafiltration is a size-exclusion process based on pressure driven membrane separation. UF membrane is capable of retaining chemical species with a molecular weight from 1.000 to 100.000 Daltons. A UF membrane is a thin layer of semi-permeable material made of at least three layers (active or selective, intermediate and support layer, respectively) (see Figure 2-8), the active layer is capable of separating substances as a function of their chemical and physical proprieties when a driving force such as pressure is applied across the membrane, while the support layer provides the mechanical strength needed (Norafifah et al., 2015). 


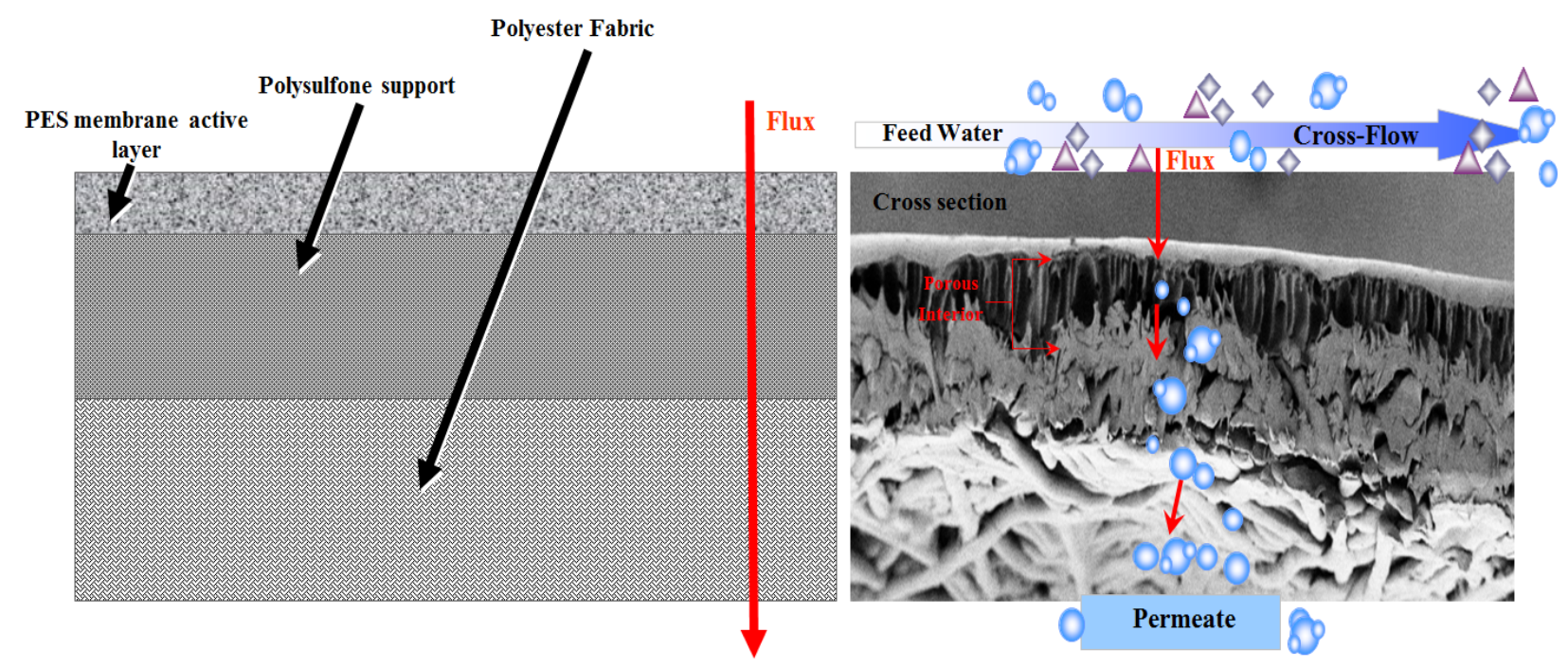

Figure 2-8 - PES composite membrane used in UF- (a) Scheme - (b) FESEM pictures (magnification $=200 \times, 100 \mu \mathrm{m}, 799 \mathrm{~V}$ ) highlighting the 3 layers.

Polymeric membranes are the most used separation media at industrial level, in chemical, biomedical, food, and water and wastewater treatment fields, thanks to the easy preparation techniques, high flexibility, and low cost than membranes constructed of other materials (Figoli and Criscuoli, 2017), although other forms, including ceramic and metallic membranes, may be available. The most commonly used commercial UF membranes are composite by organic materials, and can be made of several polymer types such as polyethersulfone (PES), polysulfone (PSU), polyvinyl pyrolidone (PVP), polyvinylidene fluoride (PVDF), Polypropylene (PP) and cellulose (Figure 2-9) (Figoli and Criscuoli, 2017; Lee et al., 2016).

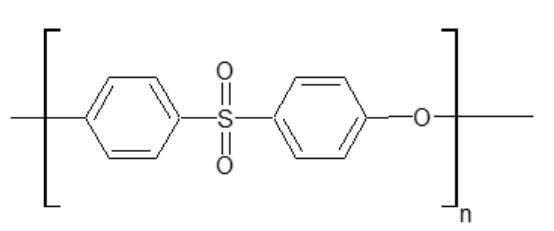

PES

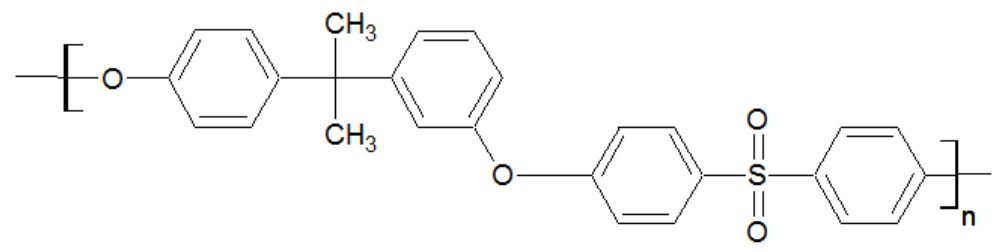

PSU

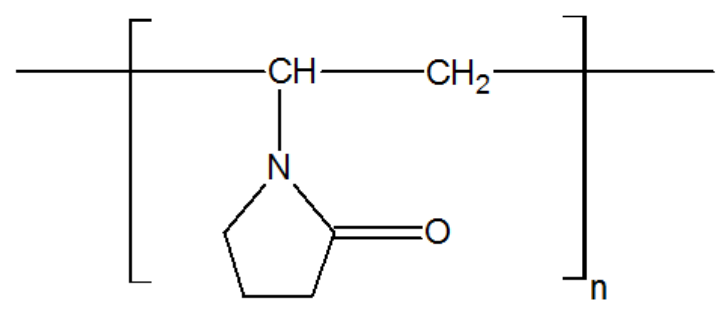

PVP

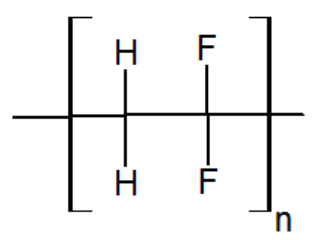

PVDF

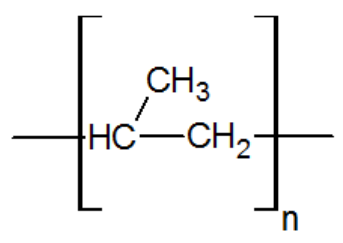

PP

Figure 2-9 - Common commercial polymers used for production UF membranes. 


\subsubsection{Comparison between Dead - end vs. cross-flow Ultrafiltration}

In membrane process, there are two basics modes of operation: dead-end and crossflow.

In dead-end operation also called direct filtration, the system have one feed flow (influent) and one permeate (effluent) stream and are similar to conventional granular media filters in terms of hydraulic configuration (Figure 2-10), it is to say, that all solution is forced through the membrane.

(a)
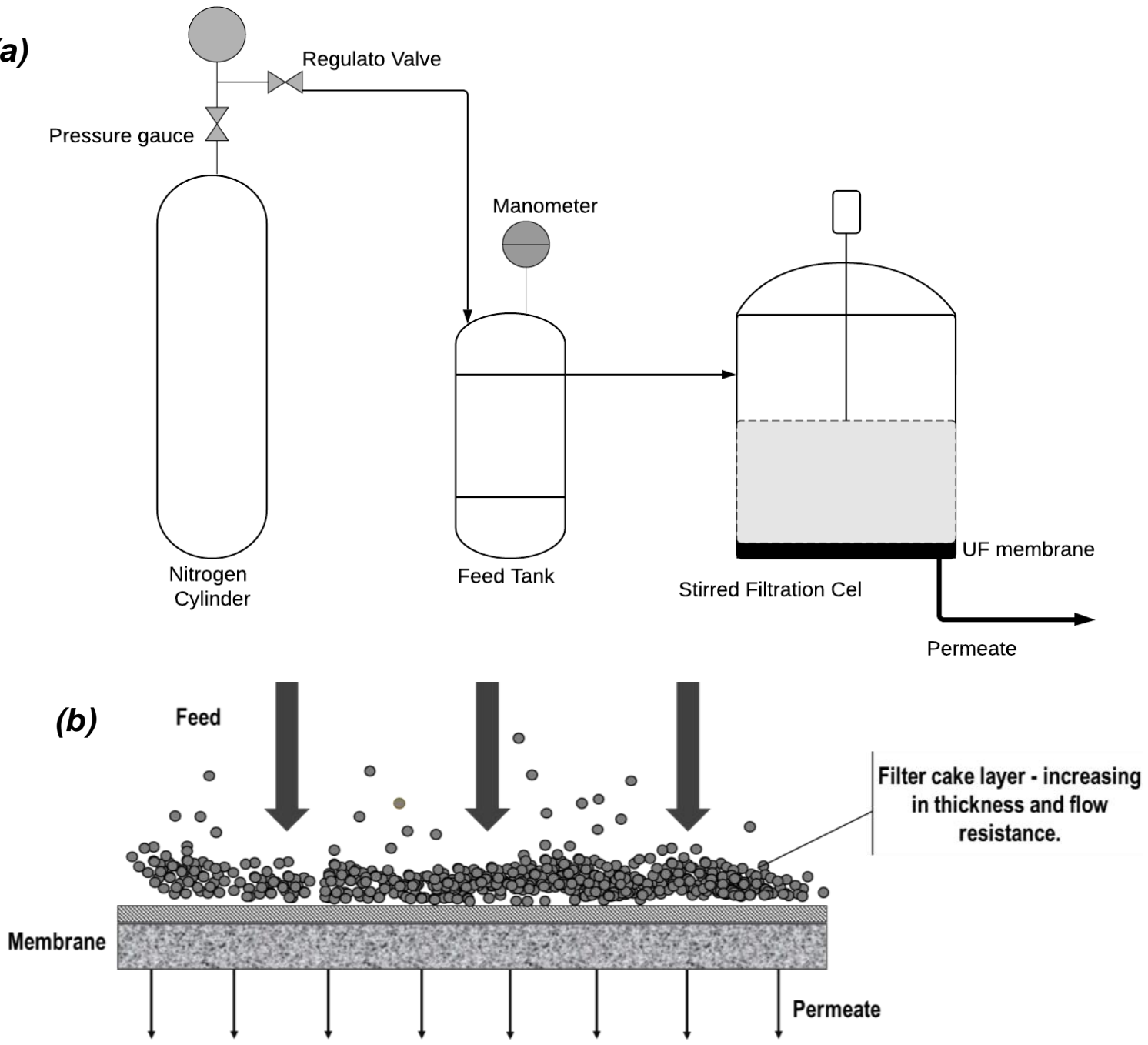

Figure 2-10 - Principle of dead - end filtration: (a) schematic diagram setup;

(b) separation mode.

In dead-end filtration, particles and solid suspended present in the feed stream accumulate on the membrane surface and are held in place by hydraulic forces acting perpendicular to the membrane, forming a quickly cake layer responsible to reduces the flux rate through the membrane due to a increase in membrane resistance. 
However, the cake layer can be removed by reversing the flow and performing a backwash, but this means that the production must be stopped.

Cross-flow filtration (CFF) also called tangential flow filtration (TFF) is a filtration technique in which the feed flow is tangentialy to the membrane surface, and is divided into two streams: the solution with components larger than the membrane pores are retained and pass along the membrane surface and, flowing back to the feed reservoir and recirculated in the process, it is called the retentate or concentrate. The solution that passes through the membrane is the permeate.

In addiction, in CFF the increase in membrane resistance associated with the membrane fouling is significantly reduced compared to dead-end filtration where the feed flows perpendicular to the membrane. A schematic for cross-flow filtration is shown in Figure 2-11.

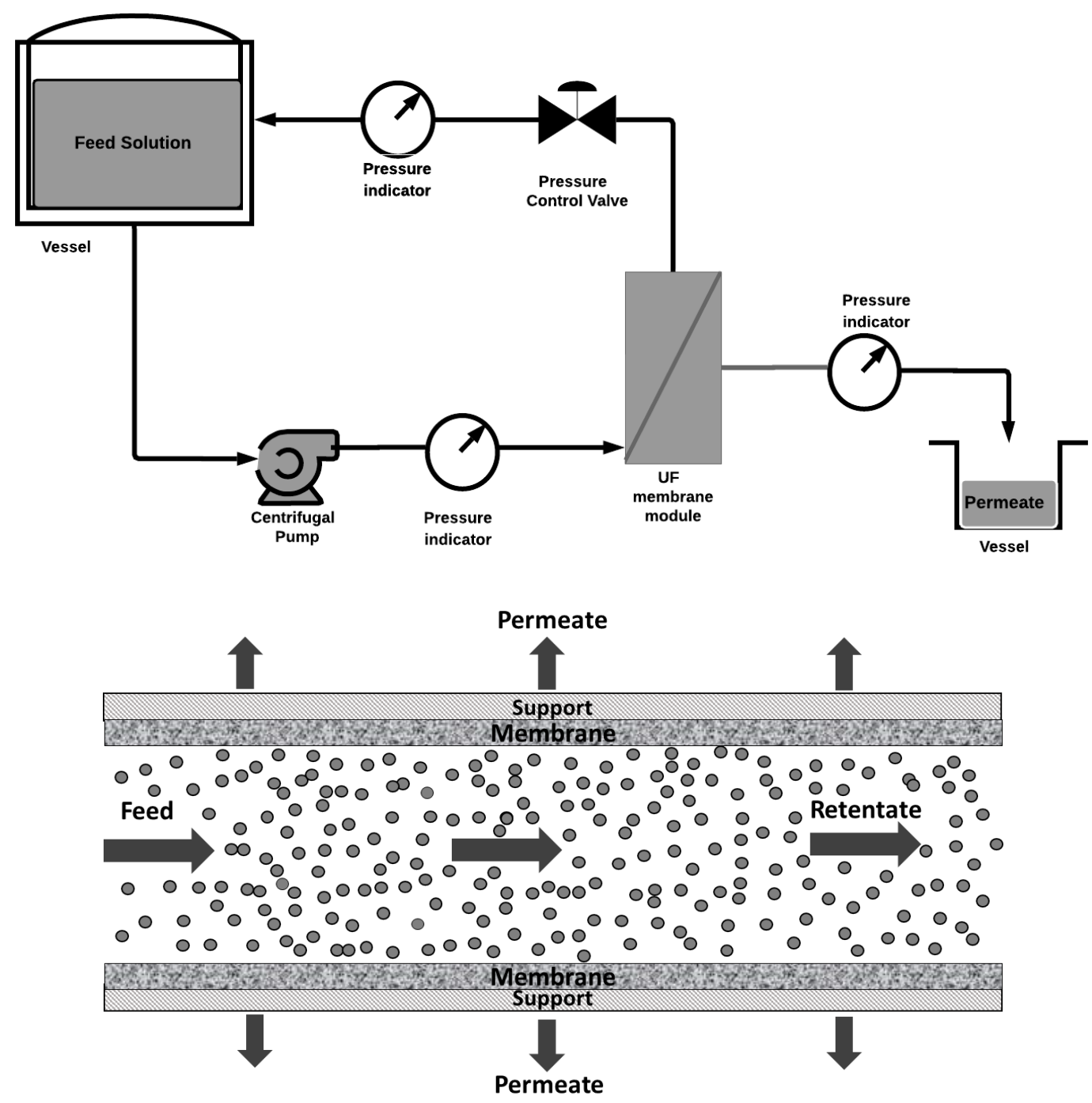

Figure 2-11 - Principle of cross flow filtration: (a) Schematic diagram of CFF system; (b) separation process. 
Membrane for CFF may be classified according to filter configuration or membrane pore size, there are two basic membrane filter configurations that usually manufactured: as hollow fibers or as flat sheet cassettes and then formed into on of several different types of membrane modules, used in this system (Figure 2-12).
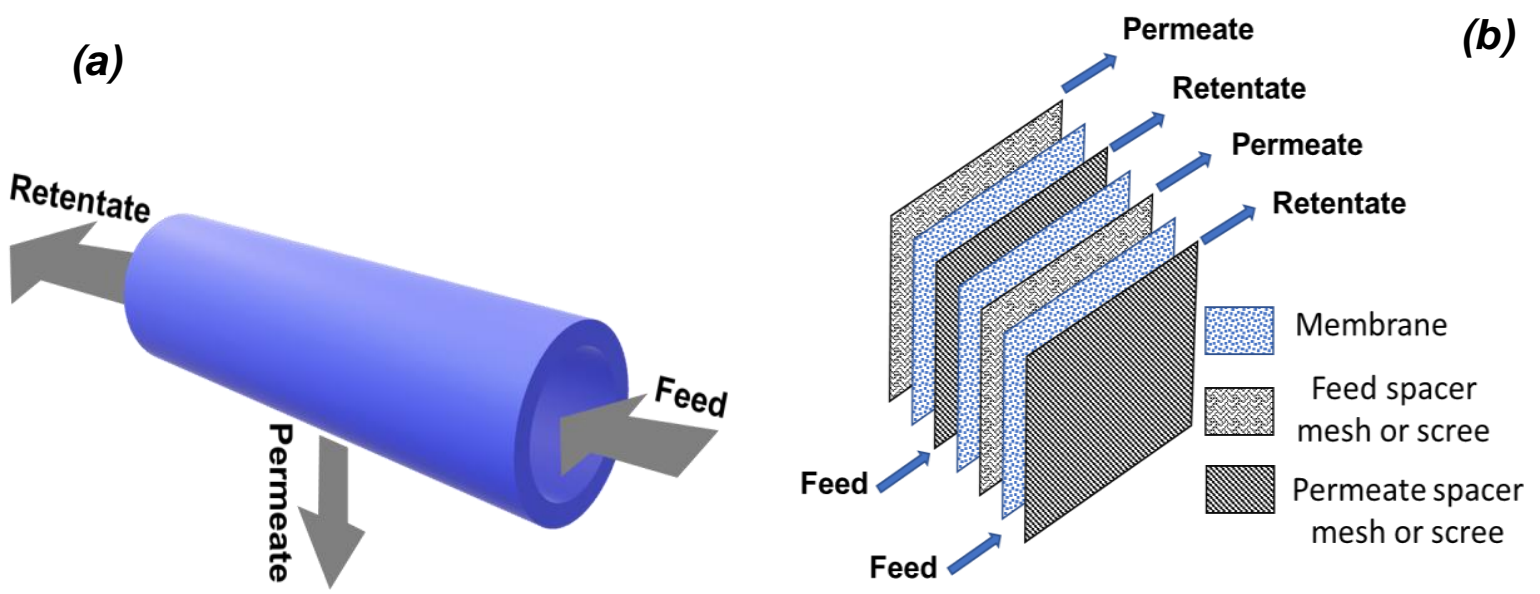

Figure 2-12 - Configuration of a) hollow fiber cartridges and b) plate and flat sheet.

The driving force in CFF is the transmembrane pressure (TMP) which describes the pressure drop across the membrane and is calculated as the pressure difference the feed pressure $\left(\mathrm{PF}_{\mathrm{F}}\right)$ and the retentate pressure $(\mathrm{Pr})$, it is to say, at the inlet and outlet of the membrane model, respectively.

$$
T M P=\Delta P=\frac{P_{F}+P_{r}}{2}-P_{p}
$$

where $P_{p}$ is the permeate pressure.

The cross-flow velocity (CFV) through the membrane is directly proportional to the volumetric flow rate $(\mathrm{Q})$ and inversely proportional to the cross-sectional area $\left(A_{c}\right)$ of the hollow fiber or flat-sheet module (cassette):

$$
C F V=\frac{Q}{A_{c}}
$$

Equation 2-2

The rate at which permeate flows through the membrane is the permeate flux $\left(U_{p}\right)$ (volume of permeate obtained per unit time and membrane area), and can be gravimetrically measured at different time intervals, as described by Darcy's Equation: 


$$
J_{p}=\frac{1}{A_{m} \rho} \frac{d m_{p}}{d t}=\frac{\Delta P}{\mu\left(R_{m}+R_{f}\right)}
$$

where,

Am is the effective membrane area $\left(\mathrm{m}^{-2}\right)$;

$m_{p}$ is the total mass of permeate $(\mathrm{kg})$;

$\rho$ is the volumetric mass density $\left(\mathrm{kg} . \mathrm{m}^{-3}\right)$;

$\mathrm{t}$ is the filtration time $(\mathrm{s})$;

$\mu$ is the filtrate viscosity (Pa.s);

$R_{m}$ is the intrinsic membrane resistance $\left(\mathrm{m}^{-1}\right)$ and;

$R_{f}$ is the fouling resistance $\left(\mathrm{m}^{-1}\right)$.

\subsubsection{Membrane Fouling}

A common problem during the membrane filtration processes, is membrane fouling. Membrane fouling leads to increase of the operating costs due to the higher pressures needed to maintain permeate flux, downtime needed for membrane cleaning and membrane replacement (Beril Gönder et al., 2011; Gao et al., 2011; Safazadeh Haghighi, 2011).

Membrane fouling is caused by precipitation, deposition or adsorption of the particles and molecules contained in the feed stream on the membrane surface or in the membrane pores. Membrane fouling is mainly attributed to (Khan et al., 2011):

- Deposition of suspended solids and colloids on membrane surface;

- Adsorption of solutes, colloids and dissolved material within membranes;

- Formation of cake layer on membrane surface;

- Growth and change (composition) of cake layer during long-term operation.

A schematic diagram of the various fouling mechanisms is presented in Figure 2-13. 


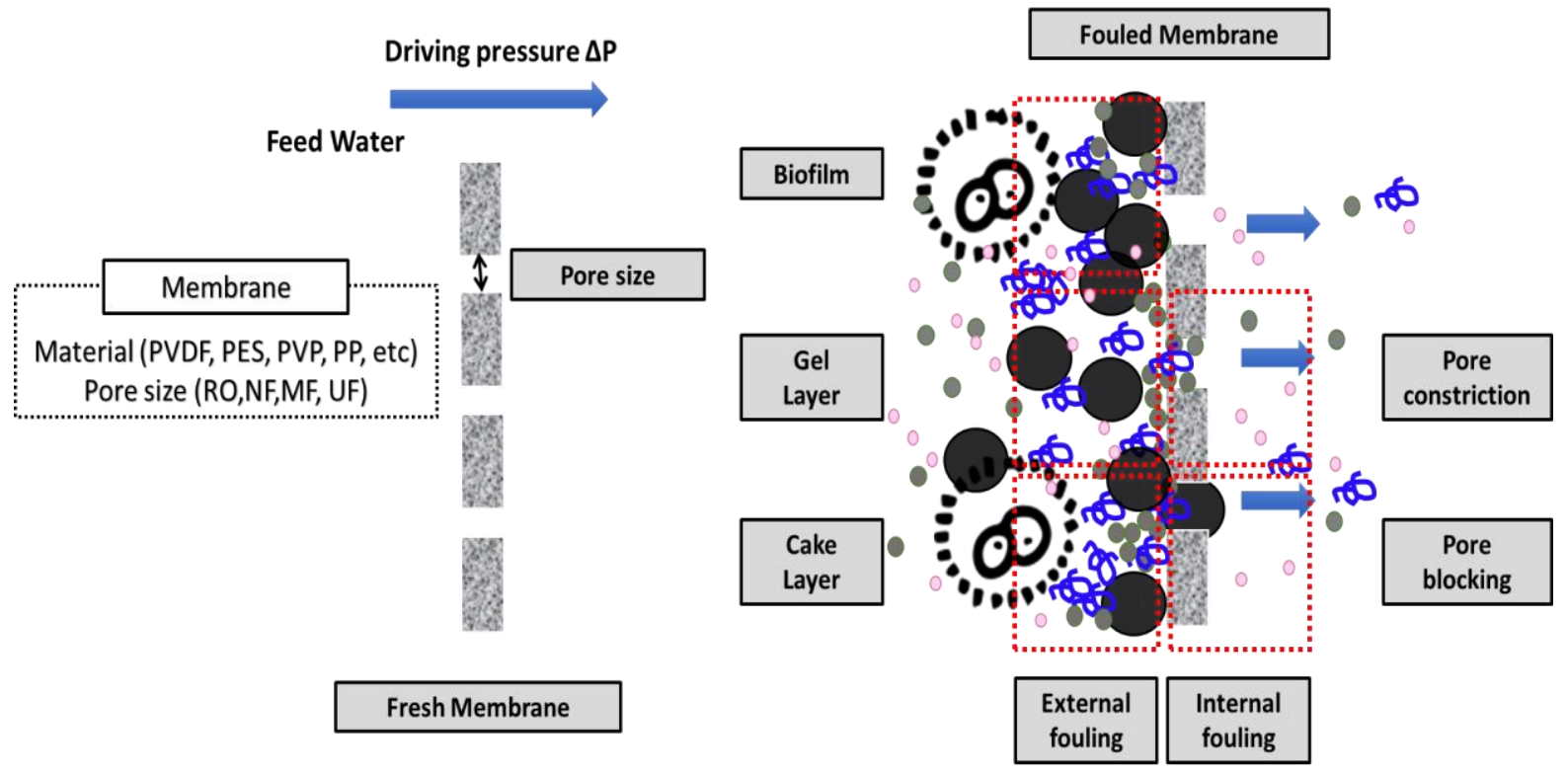

Figure 2-13 - A schematic diagram of the various fouling mechanisms on membrane.

As mentioning above, membrane fouling has a negative impact on filtration performance as it decreases the permeate flux, increase the membrane resistances and increases the TMP. Besides that, it can also change the membrane selectivity (Mulder, 1996), reduced productivity and/or recovery of the desired product (Gönder et al., 2012; Kamali and Khodaparast, 2015a; Mänttäri et al., 1997).

\subsubsection{Internal and external fouling}

Different approaches can be used to describe membrane fouling. For example, depending on the location of the fouling with respect to the membrane, external and internal membrane fouling can be distinguished.

External fouling refers to particle and suspended solids deposition or colloids and dissolved material adsorption on the membrane surface. If the fouling species form a deposit layer on the surface of the membrane, they constitute an additional resistance to the flow of the permeate through the membrane.

During internal fouling colloids, dissolved material or other molecules adsorb to the pore walls (within the membrane). This can cause pore restricting and pore blocking and change the effective pore size of the membrane or the pore size distribution (Stressmann, 2008). If pore blocking occurs, the membrane resistance to flow is increased in addition to changing the pore size distribution of the membrane. 


\subsubsection{Reversible and irreversible fouling}

Another approach to describe fouling phenomena is to characterize the reversibility of fouling. Traditionally fouling can be classified into two main categories, namely reversible fouling and irreversible fouling (Khan et al., 2016).

The term reversible fouling refers to fouling that can be easily removed from the membrane surface by physical means, such as rinsing or flushing, back-washing and relaxation (Choi et al., 2005; Stressmann, 2008). Reversible fouling occurs due to external deposition of material on to membrane surface (cake formation), due to loosely attached of the foulants it is easlily and mostly removed during filtration mechanical cleaning or backwashing cycles.

On the other hand, irreversible fouling refers to fouling which can only be removed by chemical cleaning. The attachment of the foulants on membrane is much stronger and some occasions fouling occurs inside the membrane structure, that is to say, strong cake layer and blockage of the internal membrane pore, from where the foulants are more difficult to remove (Stressmann, 2008).

\subsubsection{Prevention and reduction of membrane fouling}

Many approaches have been studied to minimize membrane fouling, such as pretreatment of water (Baek and Chang, 2009; Huang et al., 2009; Maartens et al., 1999), backwashing the membrane with or without applying chemical agents (Li, 2011; Sagiv and Semiat, 2010; Smith et al., 2006; Yigit et al., 2011), influence of operating conditions (Crozes et al., 1993; Jarma et al., 2018; Norafifah et al., 2015; Qi et al., 2011), membrane cleaning methods (hydraulic and chemical) (Beyer et al., 2017; Hashaikeh et al., 2014; Singh and Hankins, 2016) and many other conventional and no-conventional methods have been applied individually or in combinations to en hance membranes performances.

Pre-treatment is the first step to control the fouling and it can be really effective. However, it is important to realize that the applied pre-treatment method depends on the quality of the feed and also on membrane application.

Membrane cleaning is an essential step to keeping the permeate flux and selectivity of a membrane process. Cleaning can be defined as a process where material is relieved of a substance which is not an integral part of the membrane material (Ebrahim and El-Dessouky, 1994; García-Fayos et al., 2012). There are several approaches to 
membrane cleaning but it could be broadly categorized into two types: physical and chemical methods.

- Physical cleaning

Physical cleaning methods depend on mechanical forces to dislodge and remove foulants from the membrane surface. Some of these mechanical treatments include:

Hydraulic cleaning (forward, reverse flushing and backwashing),relaxation and redissolution of the foulant layer, rinsing a moderate or high shear rates, vibration, air sparging, $\mathrm{CO}_{2}$ back permeation (Al-Amoudi and Lovitt, 2007), automatic sponge ball cleaning (Psoch and Schiewer, 2006), and non-conventional physical cleaning methods such as ultrasonic cleaning (Lamminen et al., 2004; Muthukumaran et al., 2005), electrical fields (Tarazaga et al., 2006) and magnetic fields (Vedavyasan, 2001).

- Chemical cleaning

When normal mechanical and/or hydraulic forces are not sufficient to remove the fouling layer on the membrane, chemical cleaning is used. This method is the most common membrane cleaning, especially in UF membranes. The types of chemicals to be used for chemical cleaning of fouled membrane depend mainly on the fouling and foulants composition, and resistance of the membrane material to different chemical agents (Chen et al., 2006).

Once the cause of membrane fouling is recognized, different chemical agents can be applied to remove the fouling materials and recover the membrane flux. The common chemicals used in cleaning of UF membranes are categorized into five groups: alkaline solutions, acids, acid or alkaline metal chelating agents, surfactants, and enzymes (Porcelli and Judd, 2010; Regula et al., 2014).

The choice of chemical agents depends on the properties and composition of fouling layer, besides the others conditions. Alkaline solutions (sodium hydroxide) remove proteins and polysaccharides, the main foulants in the secondary effluent (Racar et al., 2017), while acids (chlorhydric and hydrofluoric) remove inorganic material (Li and Elimelech, 2004; Racar et al., 2017; Regula et al., 2014). 


\subsection{Mathematical models for membrane fouling analysis}

Fouling in membrane separation is the key factor that challenges the technology viability on ultrafiltration process. In ultrafiltration with polymeric membranes the permeate flux over time decreases quickly from the initial value during the first stage of filtration until a long and gradual decrease. Therefore, modeling of flux decline to determine the fouling mechanism in UF of macromolecules, colloids and dissolved substances is essential to predict, identify and control of membrane fouling.

\subsubsection{Pore blocking mechanisms}

The classical pore blocking mechanism model developed by Hermia. (1982) for constant pressure dead-end filtration is a function of the particles/solute size and shape in relation to the membrane pore size distribution (de Barros et al., 2003), and correspond to four basic types of mechanisms for membrane fouling: complete blocking, intermediate blocking, standard blocking and cake layer formation. The governing equation for the pore blocking mechanisms for constant flow rate in deadend filtration mode is given as shown in Equation 2-4 (Hermia, 1982) and the flux data can be plotted as $\frac{\mathrm{d}^{2} \mathrm{t}}{\mathrm{dV}^{2}}$ vS. $\frac{\mathrm{dt}}{\mathrm{dV}}$ :

$$
\frac{d^{2} t}{d V^{2}}=k\left(\frac{d t}{d V}\right)^{n}
$$

Equation 2-4

where,

$\mathrm{t}$ is the filtration time $(\mathrm{s})$;

$\mathrm{V}$ is the cumulative permeate volume $\left(\mathrm{m}^{3}\right)$;

$k$ is the resistance coefficient (phenomenological coefficient) depending on the suspension properties and operating conditions, in addition to other parameters;

$n$ is the filtration constant.

$\mathrm{n}$ is a dimensionless number that represents the fouling mode and is related to the fouling mechanism index, with 2.0 used for complete blocking, 1.5 for standard blocking, 1.0 for intermediate blocking, and 0 for cake filtration (Hermia, 1982). Figure 2-14 shows the fouling mechanisms considered by the four basic types of fouling blocking laws. 

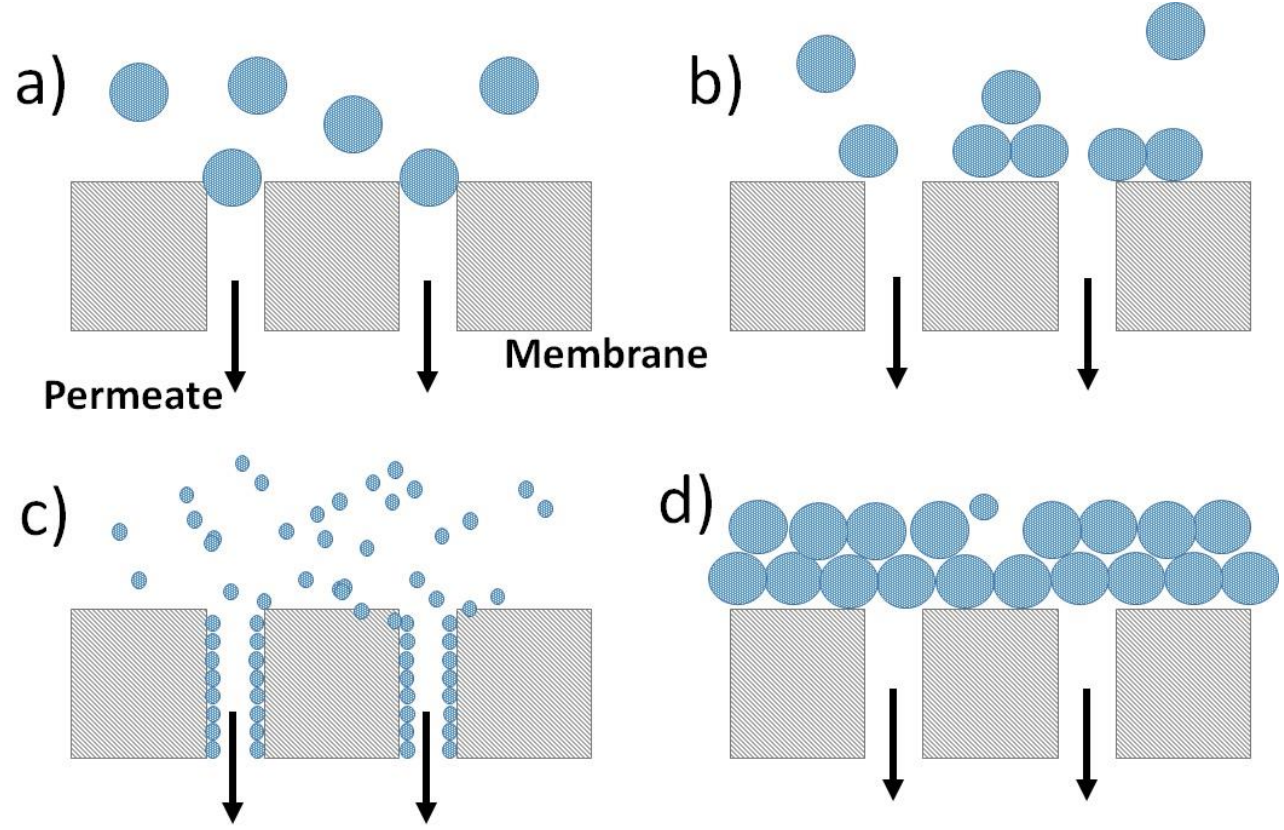

Figure 2-14 - Different fouling mechanisms happening in porous membranes (Hermia, 1982).

- Complete blocking

In the complete blocking model, it is assumed that each particle blocks an open pore completely, as shown in Figure 2-14 (a). This type of fouling occurs when the size of the solute molecules is greater than the size of membrane pores. Therefore, pore blocking takes place on the membrane surface and not inside the membrane pores (Vela et al., 2008).

- Intermediate blocking

As well as the complete blocking model, this model considers that, when a molecule approaches an open membrane pore, the molecule blocks the pore. This model assumes that the rate of pore blocking is proportional to the number of open membrane pores. Intermediate blocking occurs when the solute molecule size is similar to the membrane pore size (Figure 2-14 (b)). Thus, some molecules can obstruct a membrane pore entrance without blocking the pore completely (Vela et al., 2008).

- Standard blocking

The standard pore-blocking model considers that particles enter the membrane pores and become deposited over the pore walls, as the particle diameter is considerably smaller than the pore size (Mohammadi et al., 2003; Vela et al., 2008), as shown in Figure 2-14 (c). Thus, the pore volume decreases proportionally to the filtrate volume 
per unit membrane area, consequently the filtrate rate under constant pressure conditions decreases with decreasing pore size (Hermia, 1982).

- Cake filtration

This condition is similar to complete blocking. However, each solute molecule locates on others that have already arrived and that are already blocking some pores as there is no room to directly obstruct any membrane area(Fi eld et al., 1995; Jacob et al., 1998), as shown in Figure 2-14 (d). The solute molecules do not enter the membrane pores; they form a cake layer over the membrane surface (Vela et al., 2008). The filter cake consisting of the particles deposited on the membrane surface gradually grows as filtration continues.

\subsubsection{Pore blocking models for dead-end filtration}

For dead-end filtration the Equation 2-5 can be written in an alternative form, as follows (Yuan et al., 2002; Yuan and Zydney, 1999) :

$$
\begin{gathered}
\frac{d t}{d V}=\frac{1}{J_{p} A} \\
\frac{d^{2} t}{d V}=-\frac{1}{J_{p}{ }^{3} A^{2}} \frac{d J}{d t}=k\left(\frac{1}{A J}\right)^{n}
\end{gathered}
$$

where,

$J_{p}$ is the permeate flux $\left(\mathrm{L} \cdot \mathrm{m}^{-2} \cdot \mathrm{h}^{-1}\right)$;

$J_{0}$ is the initial permeate flux $\left(\right.$ L. $\left.\mathrm{m}^{-2} \cdot \mathrm{h}^{-1}\right)$;

$A$ is the membrane surface $\left(\mathrm{m}^{2}\right)$.

- Complete blocking filtration model $(n=2)$

For $\mathrm{n}=2$, the relationship between the permeate flux and the filtration time can be obtained by Equation 2-7 (Hermia, 1982).

$$
J_{p}=J_{0} \exp \left(-K_{c b} t\right)
$$

Equation 2-7

Therefore, decrease of the number of membrane pores leads the increase to filtration resistance (Hwang and Lin, 2002). The parameter $K_{c b}$ can be expressed as a function of the membrane surface blocked per unit of the total volume that permeates through 
the membrane, $K_{A}$, and as a function of the $J_{0}$, according to Equation 2-8 (Bowen et al., 1995).

$$
K_{c b}=K_{A} J_{0}
$$

Equation 2-8

Consequently, the active membrane surface decreases as a consequence of their pores being completely blocked (de Barros et al., 2003).

where,

$K_{c b}$ is the constant that corresponds to the complete blocking model in dead-end filtration $\left(\mathrm{s}^{-1}\right)$;

$K_{A}$ is the parameter that represents the membrane surface blocked per unit of the total volume permeated through the membrane $\left(\mathrm{m}^{-1}\right)$.

- Intermediate blocking model $(n=1)$

For $n$ equal to 1, the permeate flux as a function of time is given by Equation 2-9:

$$
J_{p}=\frac{J_{0}}{\left(1+J_{0} K_{i b} t\right)}
$$

The parameter $K_{i b}$ can be expressed (Bowen et al., 1995) as a function of blocked membrane surface per unit of the total volume that permeates through the membrane, $K_{A}$, (Equation 2-10).

$$
K_{i b}=K_{A}
$$

Equation 2-10

Besides that the membrane surface that is not blocked diminishes with time (Koĺtuniewicz and Field, 1996; Wang and Tarabara, 2008).

where,

$K_{i b}$ is the constant that corresponds to the intermediate blocking model in dead-end filtration $\left(\mathrm{s}^{-1}\right)$;

- Standard blocking model $(n=3 / 2)$

For $n=3 / 2$, the equation to describe the relationshipbetween the filtrate volume and filtration time, is the following (Vela et al., 2008):

$$
J_{p}=\frac{J_{0}}{\left(1+J_{0}{ }^{1 / 2} K_{s b} t\right)^{2}}
$$


The parameter, $K_{s b}$, is defined in Equation 2-12.

$$
K_{s b}=\frac{K_{B}}{A_{0}} A \cdot J_{0}{ }^{1 / 2}
$$

Equation 2-12

It worth mentioning that the cross section of the membrane pores decreases with time. where,

$K_{s b}$ is the constant that corresponds to the standard blocking model in dead-end filtration $\left(\mathrm{s}^{-1}\right)$;

$K_{B}$ is the parameter that represents the decrease in the cross-sectional area of the membrane pores per unit of the total volume permeated through the membrane $\left(\mathrm{m}^{-1}\right)$.

- Cake filtration model $(\mathrm{n}=0)$

For $\mathrm{n}=0$, The resulting equation in this case is:

$$
J_{p}=J_{0}\left(1+J_{0}^{2} K_{c l} t\right)^{1 / 2}
$$

The parameter $K_{c f}$ is given by Equation 2-14.

$$
K_{c l}=2 \frac{K_{D} R_{g}}{J_{0} R_{m}}
$$

where,

$K_{c l}$ is the constant that corresponds to the cake layer formation model in dead-end filtration $\left(s^{-1}\right)$;

$K_{D}$ is the parameter that represents the cake layer area per unit of the total volume permeated through the membrane $\left(\mathrm{m}^{-1}\right)$.

2.5.1.2 Pore blocking models adapted for cross-flow filtration

Hermia's models adapted to crossflow filtration has been described for many researchers to evaluate permeate flux decline in the membrane process (Brião and Tavares, 2012; de Barros et al., 2003; Field et al., 1995; Jacob et al., 1998; Li, 2011; Vincent Vela et al., 2009; Yazdanshenas etal., 2010). The general form of the equation used to derive the four fouling mechanisms in cross-flow filtration is shown in the following equation.

$$
-\frac{d J_{p}}{d t}=k\left(J_{p}-J_{s S}\right) \cdot J_{p}{ }^{2-n}
$$

where, 
$J_{s s}$ is the steady-state permeate flux $\left(\mathrm{L} \cdot \mathrm{m}^{-2} \cdot \mathrm{h}^{-1}\right)$ and ;

$\mathrm{K}$ (depends of the pore blocking mechanism) and $n$ (dimensionless) are a phenomenological coefficientand a general index, respectively, both depending on the fouling mechanism.

- Complete blocking model for crossflow filtration $(n=2)$

The equation from $J_{p}(t)$ in terms of derivate can be written as (Field et al., 1995):

$$
\frac{d J_{p}}{d t}=-\left(\frac{\sigma J_{0}}{\epsilon_{0}}\right) J_{p}+B J_{0}
$$

Equation 2-16

writing $K_{c b}=\frac{\sigma J_{0}}{\epsilon_{0}}$ and $J_{s s}=\frac{B \epsilon_{0}}{\sigma}$

The Equation 2-16 can be integrated to give a simple relationship by the permeate flux and time (Field et al., 1995; Hermia, 1982).

$$
J_{p(\mathrm{cb})}=J_{s s}+\left(J_{0}-J_{s s}\right) \cdot e^{-K_{c b} \cdot t}
$$

where,

$\sigma$ is the blocking coefficient $\left(\mathrm{m}^{-1}\right)$ (blocked area per unit of filtrate volume);

$\epsilon_{0}$ is the membrane surface porosity (clean membrane) and;

$B$ is a constant related to the membrane porosity and rate of removal of particles per unit area $\left(\mathrm{m}^{-1}\right)$.

- Intermediate blocking model for crossflow filtration $(n=1)$

For the cross-flow filtration, the rate of flux decline is given by Equation 2-18 (Field et al., 1995; Vincent Vela et al., 2009):

$$
-\frac{1}{J_{p}} \frac{d J_{p}}{d t}=\sigma J-B^{\prime}
$$

Where,

$\sigma$ is the same blocking coefficient described during derivation of the complete blocking equation representing the blocked area per unit of volume filtered $\left(\mathrm{m}^{-1}\right)$ and;

$B^{\prime}$ is the back flux factor.

Hence, writing $J_{0}=\sigma B^{\prime}$ and solving Equation 2-18 it can be obtained the relationship between the permeate flux and the filtration time. 


$$
J_{p(I B)}=\frac{J_{0} \cdot J_{S S} \cdot e^{K_{i b} \cdot J_{S S} \cdot t}}{J_{S S}+J_{0}\left(e^{K_{i b} \cdot J_{S S} \cdot t}-1\right)}
$$

The parameter $K_{i b}$ is equal to the parameter $K_{c b}$ in Equation 2-16 (Vincent Vela et al., 2009).

- Standard blocking model for crossflow filtration $(n=3 / 2)$

When internal pore blocking take places on membrane, fouling becomes independent of cross-flow velocity and no steady-state permeate flux can be achieved, i.e. $J_{s s}=0$, for long time operating (de Barros et al., 2003).

Therefore, the Equation 2-15 can are solved to show that fouling of this type produces a linear relationship between $1 / J_{p}{ }^{0.5}$ and $t$ as described in Equation 2-20 (Brião and Tavares, 2012; de Barros et al., 2003; Vincent Vela et al., 2009).

$$
1 / J_{p(S B)} 0.5=1 / J_{0} 0.5+\left(\frac{K_{S}^{\prime}}{2}\right) A^{0.5} t
$$

where,

$K_{S b}=\left(\frac{K_{S}^{\prime}}{2}\right) A^{0.5}$ is the standard blocking coefficient;

$K_{S}^{\prime}$ is the decrease in the cross-sectional area of membrane pores (due to adsorption on the pore walls) per unitof total volume permeated through the membrane $\left(\mathrm{m}^{-1}\right)$ and; $A$ is the membrane surface area $\left(\mathrm{m}^{2}\right)$.

- Cake formation model for crossflow filtration $(n=0)$

The resulting equation for the relationship between flux and time can be written as Equation 2-21 (Field et al., 1995).

$$
-\frac{1}{J_{p}^{2}} \frac{d J_{p}}{d t}=\frac{\alpha k_{c} J}{J_{0} R_{m}}-\frac{\alpha S}{J_{0} R_{m}}
$$

where,

$\alpha$ is the specific cake resistance $\left(\mathrm{m} . \mathrm{kg}^{-1}\right)$;

$k_{c f}$ is the cake filtration constant $\left(\mathrm{kg} \cdot \mathrm{m}^{-3}\right)$;

$R_{m}$ is the initial hydraulic resistance and and;

$S$ is the rate of erosion of cake per unit area in $\left(\mathrm{kg} \cdot \mathrm{m}^{-2} \cdot \mathrm{s}^{-1}\right)$.

writing $K_{c l}=\frac{\alpha k_{c}}{J_{0} R_{m}}$ and $J_{s s}=\frac{S}{\sigma k_{c}}$ 
Therefore,

$$
-\frac{1}{J_{p}^{2}} \frac{d J_{p}}{d t}=K_{c l}\left(J_{p}-J_{s S}\right)
$$

Equation 2-22

The Equation 2-22 can be solved to give the cake formation model for crossflow filtration (Brião and Tavares, 2012; de Barros et al., 2003; Vincent Vela et al., 2009):

$$
J_{s S}^{2} \cdot K_{c l} \cdot t=\ln \left[\left(\frac{J_{p(C F)}}{J_{0}} \cdot \frac{J_{0}-J_{s S}}{J_{p(C F)}-J_{s S}}\right)\right]-J_{s s}\left(\frac{1}{J_{p(C F)}}-\frac{1}{J_{0}}\right) \quad \text { Equation 2-23 }
$$

\subsubsection{Resistance-in-series model}

The resistance-in-series model is based on the Darcy's law, and has been used to evaluate fouling in membrane processv(Carbonell-Alcaina et al., 2016; CorbatónBáguena et al., 2017, 2015). This model relates the permeate flux with the transmembrane pressure (TMP), the feed solution viscosity and the total hydraulic resistance according Equation 2-24 (Mulder, 1996).

$$
J=K . \Delta P=\frac{\Delta P}{\mu \cdot R_{T}}
$$

where,

$J$ is the permeate flux;

$\Delta P$ is the transmembrane pressure;

$\mu$ is the feed solution viscosity and;

$R_{T}$ is the total hydraulic resistance.

The total hydraulic resistance during the filtration process can be expressed as the sum of different resistances that take place during the UF process (Choi et al., 2005, 2000). In this model, the membrane resistance, the adsorption resistance, the concentration polarisation resistance and the cake layer resistance were considered Equation 2-25 (Carrère et al., 2001; Corbatón-Báguena et al., 2015).

$$
R_{T}=R_{m}+R_{a d}+R_{p}+R_{C}
$$

Equation 2-25

Substituting Equation 2-25 into the Equation 2-24, can be expressed the general form of the resistance-in-series model represented as Equation 2-26:

$$
J=\frac{\Delta P}{\mu \cdot\left(R_{m}+R_{a d}+R_{p}+R_{C}\right)}
$$

where, 
$R_{m}$ is the intrinsic membrane resistance, characterized by mainly the pore shape and size, and membrane thickness, as determined during the manufacturing process was calculated from the pure water permeate flux:

$$
R_{m}=\frac{\Delta P}{\mu_{w} \cdot J_{w}}
$$

where $J_{w}$ is the initial water permeate flux;

$R_{a d}$ is the resistance due to adsorption on membrane surface and/or inside its pores due to solute concentration polarization. The resistance by adsorption is thermodynamically unavoidable but its contribution to the total filtration resistance is very small (Choi et al., 2005);

$R_{p}$ is the concentration polarization resistance, due to the accumulation of any soluble matter present in the feed at the membrane/solution interface and;

$R_{C}$ is the cake layer resistance.

The Equation 2-26 was used to quantify the contribution of each fouling mechanism to overall flux decline. The classification and definition of each resistance is summarized in Table 2-4

Table 2-4 - Classification of membrane resistances.

\begin{tabular}{|c|c|c|}
\hline Resistance & Definition & Description \\
\hline 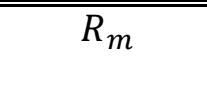 & $\begin{array}{l}\text { Intrinsic membrane } \\
\text { resistance }\end{array}$ & Pure water resistance. \\
\hline$R_{a d}$ & Adsorption resistance & $\begin{array}{l}\text { Adsorption on membrane surface and/or } \\
\text { inside its pores due to solute }\end{array}$ \\
\hline$R_{p}$ & Concentration polarization & $\begin{array}{c}\text { Concentration polarization or gel layer } \\
\text { exerted by the feed solution and removed by } \\
\text { rinse. }\end{array}$ \\
\hline$R_{C}$ & Cake resistance & $\begin{array}{c}\text { Consequence of the accumulation of } \\
\text { particles on the membrane }\end{array}$ \\
\hline$R_{p b}$ & Pore blockage resistance & Colloids block the membrane pores \\
\hline$R_{T}$ & Total resistance & $\begin{array}{l}\text { Measured at the end of feed filtration: } \\
\qquad R_{m}+R_{a d}+R_{p}+R_{C}\end{array}$ \\
\hline
\end{tabular}

2.5.3 Constant-pressure filtration and cake formation

Darcy's law is used to describe the relationship between flux, pressure and resistance in the membrane separation process. The resistance-in-series model is based on the fact that flux decline is comprised of different factors, including pore adsorption, pore 
blocking, cake formation, and concentration polarisation (Mulder,1996). In this model, permeate flux through a membrane is proportional to the applied pressure and inversely proportional to the resistance caused by the cake layer and the membrane and governed by the general filtration equation (Darcy's law) given as:

$$
J_{p}=\frac{\Delta P-\Delta P_{c}}{\mu \cdot\left[R_{m}+R_{c}(t)\right]}
$$

The hydraulic resistance due to the cake formation $R_{c}$ can be considered as the sum of three deferent factors: $R_{p}$, the polarisation layer resistance; $R_{a d}$, the fouling resistance caused by particle adsorption; and $R_{f}$, the fouling resistance, which can be divided into irreversible and reversible.

After the membrane pores have become blocked, further deposition of particles on the membrane surface will form a cake layer. Cake formation creates an additional resistance layer to the permeate flow (Monte et al., 2009). The deposition of the solute molecules (particles) on the membrane surface can be calculated using a mass balance:

$$
\delta(t)=\frac{1}{C_{g}} \int_{0}^{t} J_{p} \cdot C_{0} \cdot d t
$$

Equation 2-29

Substituting mass balance Equation 2-29 into Equation 2-28, using resistance-inseries with the $R_{m}$ and $R_{c}$ and rearranging we have:

$$
J_{p}(t)=\frac{\Delta P-\Delta P_{c}}{R_{b m}+r_{c} \cdot \delta(t)}
$$

Equation 2-30

The cake resistance is assumed to be proportional to cake thickness:

$$
R_{c}=r_{c} \cdot \delta(t)
$$

Equation 2-31

$r_{c}$ is the specific cake resistance per unit cake thickness $\left(\mathrm{m}^{2}\right)$. During constantpressure filtration, the specific flux declines over time due to the increasing cake resistance.

Filtration models often use the well-known Kozeny-Carman relationship to calculate the specific resistance of a cake with a constant concentration. These models are mostly used when colloids are being filtered (van den Berg and Smolders, 1990). To estimate the specific resistance of the fouling layer, Equation 2-32 was considered, the 
simple Carman-Kozeny equation (Chudacek and Fane, 1984; Davis, 1992; Song, 1998a).

$$
r_{c}=\frac{K \cdot \mu \cdot(1-\varepsilon)^{2}}{d_{p}^{2} \cdot \varepsilon^{3}}
$$

where $K$ is the Carmen-Kozeny constant;

$\varepsilon$ is the porosity and $d_{p}$ is the particle diameter.

The critical pressure, independent of the applied pressure and permeate flux, is determined by the thermodynamic properties of the suspensions (Song and Elimelech, 1995) and it is given by Equation 2-33:

$$
\Delta P_{c}=\frac{3 k_{m} T}{4 \pi d_{p}^{3}} N_{F c}
$$

With an estimate of specific cake resistance $\left(r_{c}\right)$ and substituting Equation 2-29 into Equation 2-30, rearranging the terms results in:

$$
\left(R_{b m}+r_{c} \cdot \frac{C_{0}}{C_{g}} \int_{0}^{t} J_{p} \cdot d t\right) \cdot J_{p}=\Delta P-\Delta P_{c}
$$

Equation 2-34 can be integrated and solved for $J_{p}$ to give an expression to predict the flux decline and the growth in cake layer as a function of time $(\mathrm{t})$ :

$$
J_{p}(t)=\frac{\left(\Delta P-\Delta P_{c}\right)}{R_{b m}}\left(1+\frac{2 r_{c}\left(\Delta P-\Delta P_{c}\right)}{R_{b m}{ }^{2}} \frac{C_{0}}{C_{g}} t\right)^{-1 / 2}
$$

Equation 2-35

Combining Equation 2-28 and Equation 2-35 we can calculate the resistance of the cake layer to the permeate flow over time.

$$
R_{c}(t)=R_{b m}\left[\left(1+\frac{2 r_{c}\left(\Delta P-\Delta P_{c}\right)}{R_{b m}{ }^{2}} \frac{C_{0}}{C_{g}} t\right)^{1 / 2}-1\right]
$$

And the cake thickness on the membrane over time is then given by:

$$
\delta(t)=\frac{R_{b m}}{r_{c}}\left[\left(1+\frac{2 r_{c}\left(\Delta P-\Delta P_{c}\right)}{R_{b m}{ }^{2}} \frac{C_{0}}{C_{g}} t\right)^{-1 / 2}-1\right]
$$

\subsection{Membrane foulants characterization and identification}

A number of different analytical techniques have been used in the literature to characterize and identify membrane foulants (C. Jacquin et al., 2018; Peiris et al., 
2010; Peldszus et al., 2011; Puro et al., 2002b; Yu et al., 2014; Z. Wang et al., 2009), such as 3D fluorescence excitation-emission matrix (3DEEM) spectroscopy, attenuated total reflection-Fourier transform infrared (ATR-FTIR), scanning electron microscopy (FESEM), SEM-energy-dispersive spectrophotometry (EDX), contact angle, streaming potential and Specific ultravioletabsorbance (SUVA). Some of These methods are described as follow sections and summarized in Table 2-9.

\subsubsection{Mainly membrane foulants components}

\subsubsection{Dissolved and colloidal substances}

Pulp and paper mill effluents can be reused for the production of different types of paper and cardboard (Bulow et al., 2003; Chen etal., 2015b), but process water cannot be recycled easily because dissolved and colloidal substances (DCS) and electrolytes become enriched with water recycling, causing serious affects on the papermaking operations and quality of the resulting paper products.

- DCS can be defined as the sum of the complex and variety organic compounds (including low-molecularweightand macromolecules, such as cellulose) (H. Liu et al., 2020), polyelectrolytes, other dissolved material, and suspended particles (dimensions less than $1 \mu \mathrm{m}$ ) present in process water or paper mill effluent (Chen et al., 2015a). Some authors reported that DCS are mainly composed of fatty and resin acids, wood resin, silicates, lignans, lignin, and lignin derivatives, hemicelluloses, sterols, steryl esters, triglycerides (Chen et al., 2015a; Hubbe et al., 2012; Miao et al., 2012a). Moreover, there are many polymer substances in the DCS component, and most of the colloids in DCS have carboxyl groups and are negatively charged (H. Liu et al., 2020).

- In general, the DCS in the papermaking mainly comes from fibre extractives, pulp, recovered fibers (RCF), waste paper and chemicals additives consumed during manufacturing process even could be react with electrolytes such as $\mathrm{Ca}^{2+}, \mathrm{Na}^{2+}$ and $\mathrm{Mg}^{2+}$ that can affect the stability of colloidal substances (CS) (Chen et al., 2015a; Hubbe et al., 2012; H. Liu et al., 2020; Ordóñez et al., 2010; Yuan et al., 2011). Hubbe et al. (2012) listed some of the prominent sources and different components of DCS in various pulp and papermaking machines (see Table 2-5). 
Table 2-5 - Sources of DCS in various pulp and paper Process Waters adapted from Hubbe et al. (2012).

\begin{tabular}{ll}
\hline \hline Possible Sources of DCS & Some components of DCS \\
\hline Wood-derived fibers & Humic acids, carboxylic acid groups, fatty acids, \\
& resin acids, hemicelluloses and pectins. \\
\hline Peroxide bleaching of mechanical & Ulronic groups, pectic acids and polygalacturonic \\
pulp & acids (PGAs). \\
\hline Black liquor carry-over & Small molecule lignin, hemicellulose (especially \\
& xylans), acetic acid, formic acid, saccharinic acids \\
& and some organic degradation of sugars. \\
\hline Deinking, recovered fiber & Cellulose, dissolved hemicellulose, organic \\
& compounds, resin acids, deinking additives and ink \\
& particles, fibers and fines. \\
\hline \hline
\end{tabular}

- Previous studies carried out by Miao et al. (2012) and Hubbe et al.(2012) demonstrated that the amount of dissolved substances comprises about $60 \%$ of DCS, and in some cases can make up $95 \%$ of the DCS, a proportion much more than that of colloidal substances. Moreover, according to research performed by Chen et al. (2015) and Puro et al. (2002a), the foulants on the membrane surface and with in pores arise from DCS, especially fatty acids, resin acids, lignins and some traces of steryl. Furthermore, the presence of dissolved multivalent metal ions, especially $\mathrm{Ca}^{2+}$, accelerated membrane fouling (Puro et al., 2002b, 2011a).

\subsubsection{Biofoulants y Organic Foulants}

During biological wastewater treatment (aerobic and/or anaerobic, microorganisms use the biodegradable organic matter as carbon and energy sources and produce biomass activity as the result of the interaction of the microorganisms with their environment (Mesquita et al., 2010).

- Many studies focused on the characterization of biological secondary effluents has been described active biomass in activated sludge mixed liquor as a complex matrix constituted of heterogeneous compounds such as fatty acids, proteins, polysaccharides, humic and fulvic sub-stances (Jacquin et al., 2017). Most of these compounds are generated within the bioreactor by the biomass activity (Extracellular polymeric substances; EPS and Soluble Microbial Products; SMP) (Jacquin et al., 2017; Q. Liu et al., 2020; Wang et al., 2008). EPSs and SMPs secretions of microorganisms with high molecular weight, 
three-dimensional, gel-like form and highly hydrated molecules (Banti et al., 2020).

- Extracellular polymeric substances (EPS) are a complex high molecular-weight mixture of polymers excreted by microorganisms, are defined as biological reaction by-products and which can occur either attached to microbial cell surfaces or flocs (Jacquin et al., 2017; Wang et al., 2008; Xie et al., 2016). EPS are classified into two groups:

- Bound-EPS (bEPS) which derive directly from the microbial cell Wall. Besides that Bound-EPS are further divided into loosely bound EPS (LBEPS), and tightly bound EPS (TBEPS) (Banti et al., 2020; Q. Liu et al., 2020; Wang et al., 2008) and;

- Soluble-EPS (sEPS) or dissolved EPS (dissolved in the liquid phase), which are generally called as Soluble Microbial Products (SMP).

- Yan et al. (2019) described that the EPS are composed by a wide range of macromolecules, such as of polysaccharides, proteins, extracellular DNA (eDNA), nucleic acids, phospholipids, metal ions and other polymeric compounds. Moreover, several researchers suggests that the proteins and polysaccharides are the major factions in EPS that contribute to biofouling, especially when they are in their soluble form as SMP (Banti et al., 2020). However, other components may also play central roles. Dissolved EPS are also referred to as SMP ( Jacquin et al., 2017), more precisely SMP are composed of various organic substances such as volatile fatty acids (VFA), polysaccharides, proteins, humic acids, nucleic acids, enzymes and lipids. (Banti et al., 2020; C. Jacquin et al., 2018). Several researchers have reported th at the SMP plays a important role in internal membrane fouling in membrane bioreactors (MBRs) during typical operating conditions, causing pore blocking and cake formation accumulate and thereby reducing permeate fluxes and productivity of the process (Mesquita et al., 2010).

- SMP have many different origins, i.e, they can be part of the debris of hydrolysed cells released into liquor during the cell lysis process, secreted during substrate metabolism from biomass growth, or even provided by the feed substrate (Banti et al., 2020; Jacquin et al., 2017; Wang et al., 2013). SMP are often classified into two main categories, based on the bacterial phase from which they were derived (Azami et al., 2012; Banti et al., 2020; Ma et al., 2015): 
- Utilization Associated Products (UAP), SMPs that are associated from the biodegradation of original substrates during the microbial growth phase, and

- Biomass-Associated Products (BAP), SMPs that are associated with biomass decay in the endogenous phase.

\subsubsection{Inorganic Foulants}

Inorganic foulants or scaling is caused by the accumulation of inorganic compounds such as metal hydroxides, and scales over the membrane surface or into the membrane pores, resulting in membrane fouling. Examples of such substances include cations and anions such as $\mathrm{Ca}^{2+}, \mathrm{Mg}^{2+}, \mathrm{Fe}^{3+}, \mathrm{Al}^{3+}, \mathrm{SO}_{4}{ }^{2-}, \mathrm{PO}_{4}{ }^{3-}, \mathrm{CO}_{3}{ }^{2-}$, $\mathrm{OH}^{-}$, etc.(Wang et al., 2008). These species precipitate onto the membrane surface when the concentration of the chemical species exceeds its saturation concentration and due to hydrolysis which leads to $\mathrm{pH}$ change, and oxidation (Nakajima, 2013).

- Several studies have shown that increased concentration of $\mathrm{Ca}^{2+}$ and $\mathrm{Mg}^{2+}$ caused more fouling (Ahn et al., 2008; Miao et al., 2018-a, 2018-b; Shirazi et al., 2010).

- It was also reported by Chen et al. (2015) that the multivalent metal ions, especially $\mathrm{Ca}^{2+}$, can easily disturb the stability of DCS via a Ca-DCS complex and aggregate formation, thus being retained on the membrane surface. Moreover, the presence of dissolved multivalent metal ions, especially $\mathrm{Ca}+$, accelerated membrane fouling.

- Wang et al. (2008) demonstrated by SEM and EDX analysis that membrane surfaces (Membrane foulant and gel layer characterization in a submerged membrane bioreactor; MBR) were covered with compact gel layer formed by organic substances and inorganic elements such as $\mathrm{Mg}, \mathrm{Al}, \mathrm{Ca}, \mathrm{Si}, \mathrm{Fe}$, etc.

- In our previous studies, EDS analyses indicate that the presence of inorganic foulants on the membrane surfaces, such as metal ions and especially Ca2+, can accelerate membrane fouling, whereas $\mathrm{Mg}$ and $\mathrm{Si}$ are linked to reversible fouling (Sousa et al., 2020).

\subsubsection{Specific ultraviolet absorbance (SUVA)}

Aromatic organic carbon matter and humic substances in DOM can be characterized using simple techniques such as total organic carbon (TOC) concentration with UV absorbance at $254 \mathrm{~nm}$, in terms of the specific UV Absorbance (SUVA). SUVA is a 
direct measure of humic substances, that is to say, it gives an indication of the presence of unsaturated organic compounds (hydrophobicity or hydrophilicity), and can be determined by the ratio between UV absorbance measured at $254 \mathrm{~nm}$ to TOC concentration multiplied by 100 (Korshin et al., 1997; Potter and Wimsatt, 2009).

High SUVA value $>4 \mathrm{~L} \cdot \mathrm{m}^{-1} . \mathrm{mg}^{-1}$ indicates presence mainly hydrophobic material and especially humic content and aromatic substances. Low SUVA (less than 3 L. $\mathrm{m}^{-1} . \mathrm{mg}^{-}$ 1) corresponds to the presence of mainly hydrophilic material with reduced aromatic character (Archer and Singer, 2006; Edzwald and Tobiason, 1999). Table 2-6 indicates the composition of DOM regarding SUVA values.

Table 2-6 - Guidelines on the nature of DOM according to SUVA. Addapted from (Cunha, 2014; Edzwald and Tobiason, 1999)

\begin{tabular}{cr}
\hline \hline SUVA $\left(\mathrm{L} \cdot \mathrm{m}^{-1} \cdot \mathrm{mg}^{-1}\right)$ & Composition \\
\hline \hline & Mostly aquatic humic material High hydrophobicity High molecular \\
& weight \\
$2-4$ & Mixture of aquatic humics and other DOM Mixture of hydrophobic and \\
$<2$ & hydrophilic DOM Mixture of molecular weights \\
\hline \hline
\end{tabular}

\subsubsection{Fluorescence spectroscopy}

Fluorescence spectroscopy is an an alytical technique used to detect different types of organic molecules by detecting the presence of certain natural fluorophores associated with different types of organic molecules (ElHadidy, 2016). Fluorophore compounds are typically compounds with aromatic rings, conjugated double bonds or similar rigid structures that prevent relaxation through torsional energy (Hudson et al., 2007). Common examples of fluorophores are the tyrosine, tryptophan, proteins, aromatic amino acids, phenylalanine and, humic and fulvic substances (Chen et al., 2003b; Peiris et al., 2010; Wang et al., 2017).

Previous studies (Carstea et al., 2016; Chen et al., 2003b; Coble et al., 2014; Hudson et al., 2008) shown that fluorescence spectroscopy could be used to characterize organic matter in wastewater and effluents quality, as a tool for control discharge in wastewater treatment plants (WWTPs). Moreover, recent studies have proved the potential of fluorescence spectroscopy to identify, characterize and monitoring organic matter in membrane fouling (C. Jacquin et al., 2018; Maghsoodi et al., 2019; Qu et al., 2012; Shao et al., 2014; Tian et al., 2015; Wang et al., 2017; Z. Wang et al., 2009; Zhu 
et al., 2011). Therefore, fluorescence excitation-emission matrix (EEM) spectroscopy could be used as powerful technique for identification, and characterization of this foulants on membrane, besides to contribute with information to establish strategies to processes optimization in order to prevent and eliminate this undesirable phenomenon (C. Jacquin et al., 2018; Peiris et al., 2010; Peldszus et al., 2011a; Yu et al., 2014; Z. Wang et al., 2009).

In this study, the paper mill effluent (feed solution and permeates) and membrane foulants were analyzed qualitatively and calculated quantitatively using 3DEEM spectroscopy, by fluorescence parameters, such as peak location, fluorescence intensity and, volume of fluorescence $\Phi$ (i) (R.U.nm²) parameters from the Fluorescence Regional Integration (FRI) method originally proposed by (Chen et al., 2003b). FRI methodology permits classify the DOM and divide the EEM spectroscopy into the five main regions (Chen et al., 2003b), as shown in Figure 2-15.

Region I $\left(\lambda_{e x}=220-250 \mathrm{~nm} ; \lambda_{e m}=280-332 \mathrm{~nm}\right)$ is associated with aromatic proteinlike fluorophores type I (tyrosine type), region II $\left(\lambda_{\text {ex }}=220-250 \mathrm{~nm} ; \lambda_{\text {em }}=332-380 \mathrm{~nm}\right.$ ) is associated to aromatic protein-like fluorophores type II (BOD5), region III ( $\lambda_{e x}=220$ $250 \mathrm{~nm} ; \lambda_{\text {em }}=380-580 \mathrm{~nm}$ ) corresponds to fulvic acid-like fluorophores; and region IV $\left(\lambda_{e x}=250-470 \mathrm{~nm} ; \lambda_{e m}=280-380 \mathrm{~nm}\right)$ and $\mathrm{V}\left(\lambda_{e x}=250-470 \mathrm{~nm} ; \lambda_{\text {em }}=380-580 \mathrm{~nm}\right)$ are associated with SMP-like fluorophores (tryptophane type) and humic acid-like fluorophores, respectively. It is worth mentioning that previous studies have been shown that humic and fulvic acids have multiple fluorescence peaks, that can be overlap in both region III and V (C. Jacquin et al., 2018; Chen et al., 2003b; Hudson et al., 2007). 


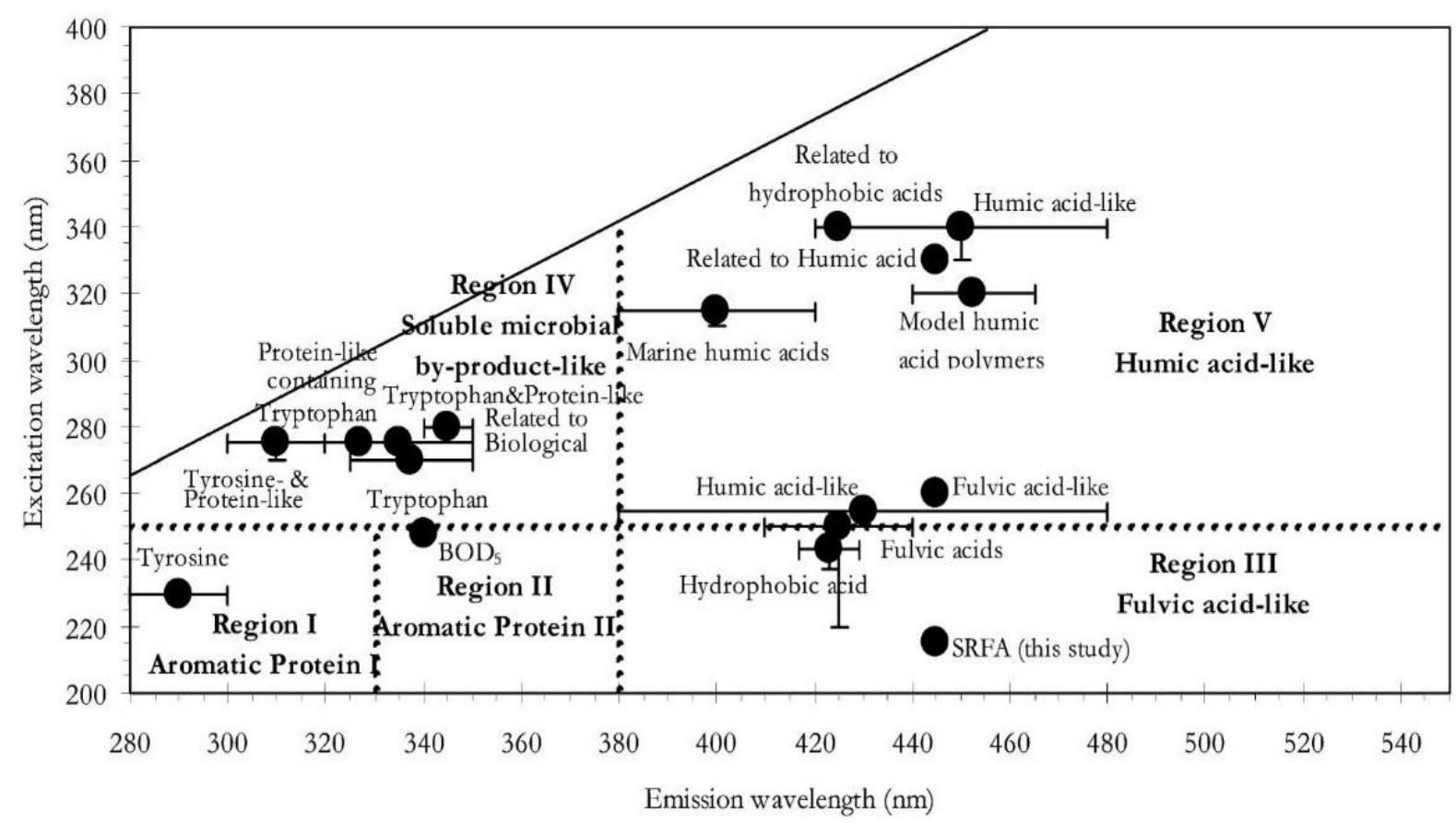

Figure 2-15 - Excitation and emission wavelength boundaries for natural organic matter (Chen et al., 2003b).

Another very simple tool to identify organic associated flu orophores is by their chemical characteristics after fractionation (hydrophobic/ hydrophilic and acid, base or neutral) (Hudson et al., 2007; Wu et al., 2003) and, classify the fluorescence into maximum intensity peaks ( $A, C, M, B$ and $T$ ), on the basis of their corresponding excitation and emission wavelength pairs (peak-picking method) (Hudson et al., 2007). Theses fluorescence components have been previously described by Coble. (1996), and the components and fluorescence peaks are detailed in Table 2-7.

Table 2-7 - Commonly identified PARAFAC components and their corresponding peaks identified in Coble. (1996). Adapted from B. Fellman et al., 2010 and Hudson et al., 2007.

\begin{tabular}{|c|c|c|c|c|}
\hline $\begin{array}{l}\text { Peak } \\
\text { label }\end{array}$ & $\begin{array}{l}\text { Associated } \\
\text { fluorophores }\end{array}$ & $\begin{array}{c}\lambda_{e x} \\
(\mathrm{~nm})\end{array}$ & $\begin{array}{c}\lambda_{\text {em }} \\
(\mathrm{nm})\end{array}$ & Description \\
\hline$\overline{\bar{B}}$ & $\begin{array}{l}\text { Tyrosine-like, } \\
\text { protein-like }\end{array}$ & $27270-280$ & $300-320$ & $\begin{array}{l}\text { Microbially-derived and associated with } \\
\text { amino-acid and protein presence. }\end{array}$ \\
\hline $\mathrm{T}$ & $\begin{array}{l}\text { Tryptophan- like, } \\
\text { protein-like }\end{array}$ & $270-280$ & $320-350$ & $\begin{array}{l}\text { Microbially-derived and associated with } \\
\text { protein presence. }\end{array}$ \\
\hline$A$ & Humic- like & $250-260$ & $380-480$ & High molecular weight, aromatic humic. \\
\hline M & $\begin{array}{c}\text { Humic-like } \\
\text { (Marine humic-like) }\end{array}$ & $310-320$ & $380-420$ & $\begin{array}{l}\text { Low molecular weight, associated with } \\
\text { biological activity. }\end{array}$ \\
\hline C & Humic- like & $330-350$ & $420-480$ & $\begin{array}{l}\text { High molecular weight aromatic } \\
\text { compunds, humic humic-like } \\
\text { fluorescence. }\end{array}$ \\
\hline
\end{tabular}

Nomenclature consistent with peak ranges from Coble et al. (2014) and Coble. (1996). 
Peak A $\left(\lambda_{e x} / \lambda_{e m}=250-260 / 380-460 \mathrm{~nm}\right)$ and Peak $C\left(\lambda_{e x} / \lambda_{e m}=250-260 / 380-460 \mathrm{~nm}\right)$ are commonly associated with humic-like (Baker and Spencer, 2004; Coble, 1996), Peaks B $\left(\lambda_{e x} / \lambda_{e m}=270-280 / 300-320 \mathrm{~nm}\right)$ and Peak $\mathrm{T}\left(\lambda_{e x} / \lambda_{e m}=270-280 / 320-350 \mathrm{~nm}\right)$ is related to microbial activity (proteins) specifically amino acid tryptophan (Coble, 1996; Hudson et al., 2008, 2007), and Peak $M\left(\lambda_{e x} / \lambda_{e m}=310-320 / 380-420 \mathrm{~nm}\right)$ linked to humic-like or protein-like (Coble et al., 2014; Coble, 1996) (Table 2-2). An example of the typical peak-picking analysis is shown in Figure 2-16.

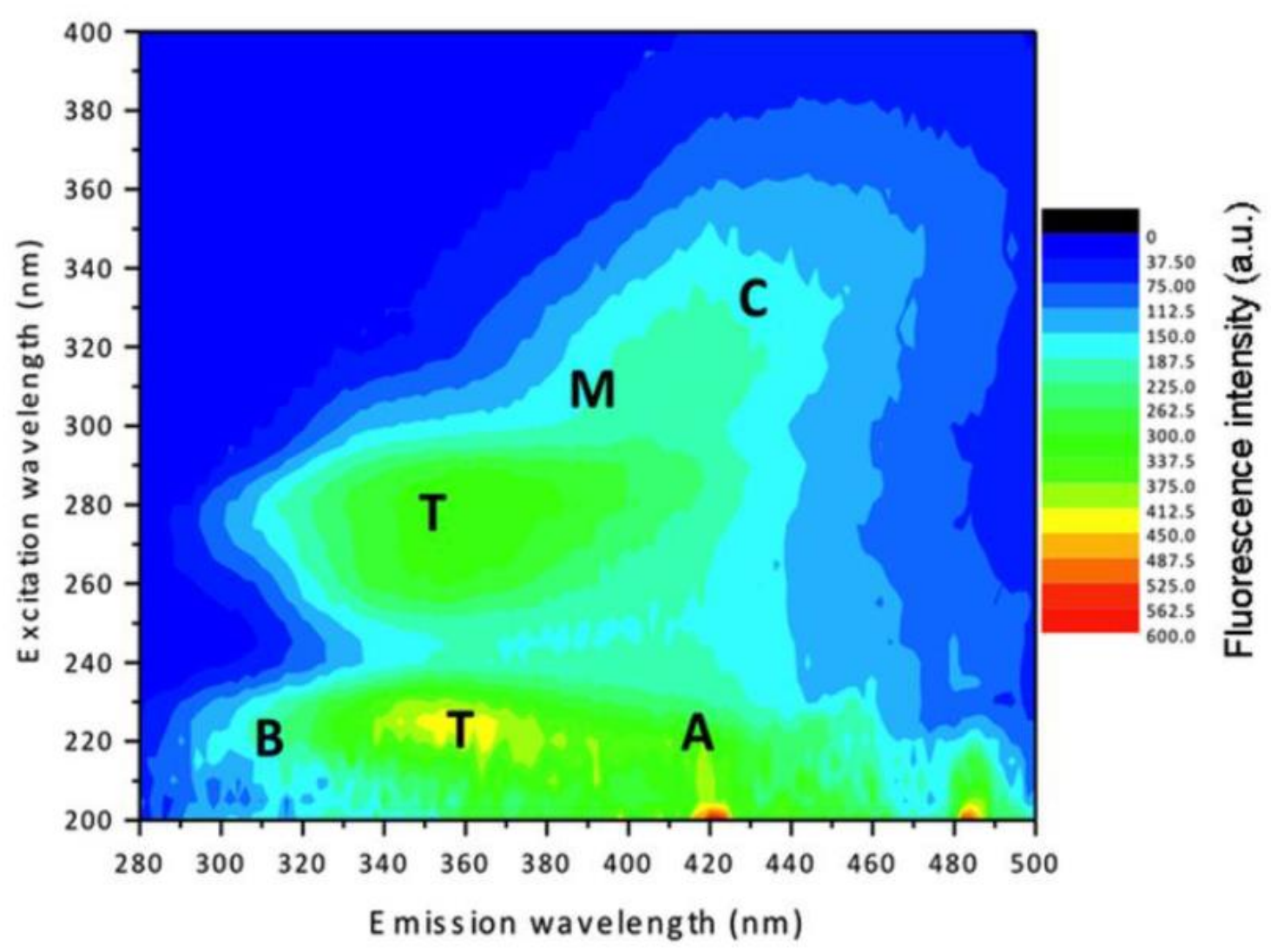

Figure 2-16 - Locations of fluorescence Peaks A, B, C, T and M. (adopted from Hudson et al., 2007).

\subsubsection{Attenuated total reflection-Fourier transform infrared (ATR-FTIR)}

Attenuated total reflection-Fourier transform infrared (ATR-FTIR) uses measurements of vibrational energy of atomic bonds to provide a detailed analysis of the chemical functional groups of unknown materials (Zularisam et al., 2006). The functional groups absorb energy at specific wavelengths (spectral range $4.000-400 \mathrm{~cm}^{-1}$ ), which can be shifted in intensity or position by substituent effects from adjacent atoms (Howe et al., 2002). ATR-FTIR spectra are usually divided into two regions: the functional group region $\left(4.000-1.350 \mathrm{~cm}^{-1}\right)$ and the fingerprint region $\left(1.350-400 \mathrm{~cm}^{-1}\right)$ (Chen et al., 2018). 
In literature, several researches have been applied (ATR-FTIR) to detect the presence of different bands of the fouling layer on fouled membranes such as proteins, fatty and resin acids, colloids, polysaccharides and membrane substrates (Carlsson et al., 1998; Chen et al., 2018; Delaunay et al., 2008; Howe et al., 2002; Jensen et al., 2015; Pihlajamäki et al., 1998), besides to provide an easy and interpretable overview of fouling distribution over the virgin and fouled membrane (Chen et al., 2018). Gelaw et al. (2014) used ATR-FTIR to examine the efficiencies of cleaning protocols applied to remove membrane fouling after membrane emulsification. Delaunay et al. (2008) have been mapped quantitatively protein fouling by FTIR-ATR. Carlsson et al. (1998) studied surface of membranes fouled from pulp mill effluent by FTIR-ATR.

However, ATR-FTIR spectra applied in fouling characterization and foulants identification provide a fingerprint of the samples with multiple absorbance bands, some arising from the membrane material (polyethersulfone, cellulose acetate, polypropylene, ceramic and others materials ) and some due to the fouling material (organic and inorganic foulants), it is essential to ensure that the peaks investigated and quantified are correctly identified. Based on the study carried out by Jensen et al. (2015), Table 2-8 shows the most common peaks from PES UF membrane and the residual fouling found in the ATR-FTIR spectrum.

Previous studies demonstrated that the peaks for the fresh PES ultrafiltration membranes were found around $1147.34 \mathrm{~cm}^{-1}$ can be assigned to $\mathrm{S}=\mathrm{O}$ symmetric stretching mode in-SO2- (Angione et al., 2015), $1240 \mathrm{~cm}^{-1}$ which arises from the asymmetric stretch of the aromatic ether (Ar-O-Ar ethers) in the polyethersulfone (Jensen et al., 2015), and $1643 \mathrm{~cm}^{-1}$ and $3400 \mathrm{~cm}^{-1}$ characteristic for the aromatic bands and aromatic double (bonded carbons), respectively. 
Table 2-8 - The most common peaks from PES and the residual fouling found in the IR spectrum.

\begin{tabular}{|c|c|c|c|}
\hline Wavenumber $\left(\mathrm{cm}^{-1}\right)$ & Conformation & PES & Fouling \\
\hline $825-875$ & C-H out of plane bend & & $\bar{x}$ \\
\hline 1100 & C-O stretch (Polysaccharide-like) & $x$ & $x$ \\
\hline 1150 & C-O stretch (Polysaccharide-like) & $x$ & $x$ \\
\hline 1240 & Asymmetric stretch of the aromatic ethe & $x$ & \\
\hline 1300 & C-O stretch & $x$ & \\
\hline 1325 & C-O stretch & $x$ & \\
\hline 1475 & $\mathrm{C}-\mathrm{H}$ bend & $x$ & \\
\hline $1650-1657$ & $\mathrm{C}=\mathrm{O}$ (Amide I, primary peptide carbonyls) & & $x$ \\
\hline $1530-1550$ & & & $x$ \\
\hline $1626-1640$ & Amide II ( $\mathrm{C}-\mathrm{N}$ and $\mathrm{N}-\mathrm{H}$ bonds) & & \\
\hline $1655-1675$ & Turn (Secondary structure $\beta$-lactoglobulin/other & & $x$ \\
\hline $1680-1696$ & proteins). & & \\
\hline $1640-1651$ & Amide I $(\mathrm{C}=\mathrm{O})$ & & $x$ \\
\hline 1745 & $\mathrm{C}=\mathrm{O}$ stretch & & $x$ \\
\hline 2700-3000 & $\mathrm{C}-\mathrm{H}$ stretch & $x$ & $x$ \\
\hline $2850-2930$ & Aliphatic- $\mathrm{CH} 2$ asymmetrical stretching & $x$ & \\
\hline $3300-3500$ & O-H stretch (alcohol) & & $x$ \\
\hline
\end{tabular}

* Adapted from Jensen et al. (2015), Her et al. (2004), Carlsson et al.(1998), Ramamurthy et al. (1995) and Puro et al. (2011b).

In addiction, an important characteristic of all this foulants compounds characteristic from membrane fouled by paper mill effluent is that contain the group $\mathrm{C}=\mathrm{O}$ in their structures like as carboxylic $[-\mathrm{C}(=\mathrm{O})-\mathrm{OH}]$ or carboxylate $[-\mathrm{C}(=\mathrm{O})-\mathrm{O}-$ ] absorbing in a strong band in the range about $1690-1750 \mathrm{~cm}^{-1}$ and $1550 \mathrm{~cm}^{-1}$, respectively and all carbohydrates absorb at about $3400 \mathrm{~cm}^{-1}(-\mathrm{C}-\mathrm{OH})$ and at about $1060 \mathrm{~cm}^{-1}(-\mathrm{C}-\mathrm{OH}$ or C-O-C) (Carlsson et al., 1998). Thus, this band is significant in IR (Infrared) on the fouled membranes to the fouling analysis. As Figure 2-17 shows there is a good opposite correlation between peaks corresponding to foulants and membrane material, meanly at $3700-3000 \mathrm{~cm}^{-1}$ and at $1020 \mathrm{~cm}^{-1}$. 


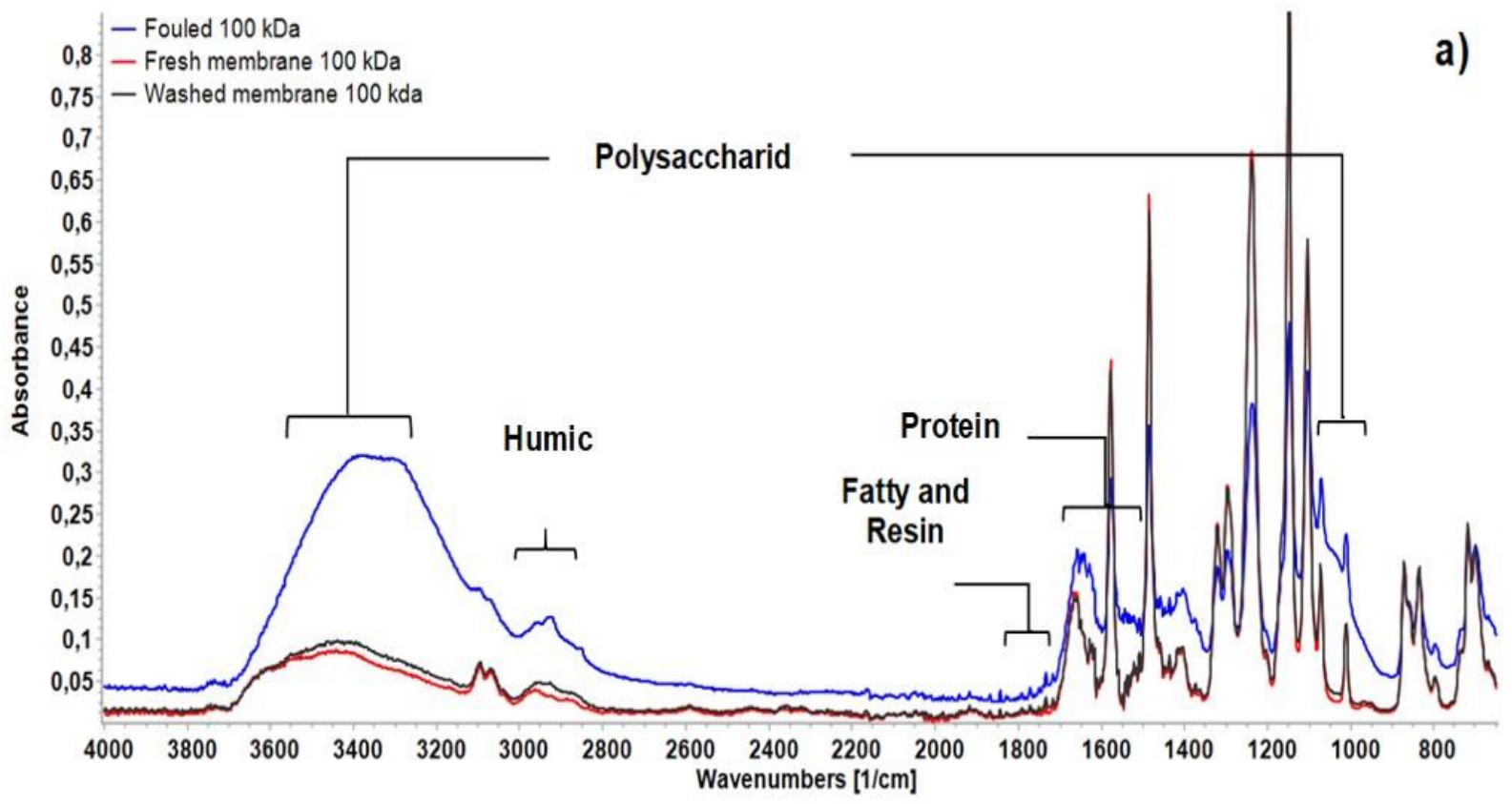

Figure 2-17 - Spectra of PES UF membrane and fouled membrane by paper mill treated effluent.

Figure 2-18 shows a schematic illustration of ATR-FTIR measurement, the sample are form for a two phase's system: ultrafiltration membrane (that consists in two layers, the active PES layer and thicker support polyester (PE) layer) and residual foulants layer (Figure 2-18). In this case IR beam penetrate, successively in the fouling layer, the active layer of the membrane and finally the support layer.

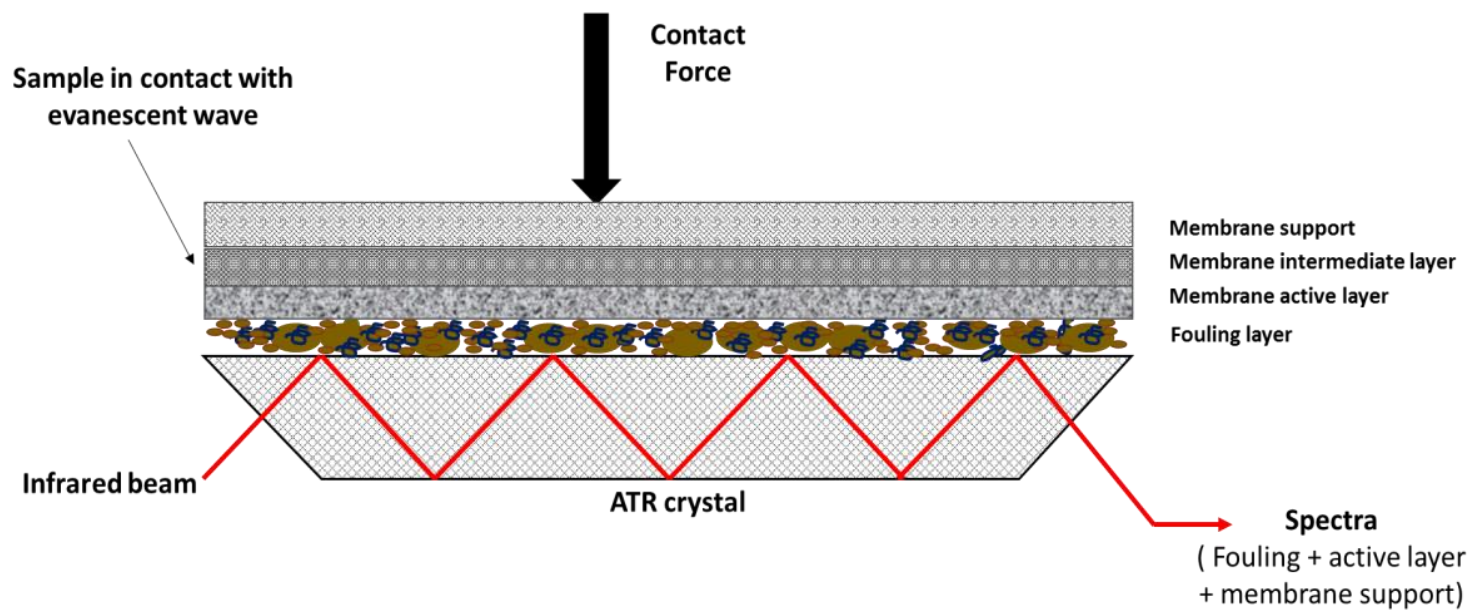

Figure 2-18 - Illustration of the membrane interfacing with the ATR crystal (successively fouling layer/active layer of membrane and support layer of membrane). 


\subsubsection{Scanning electron microscopy (FESEM)}

SEM or FESEM provides images of the sample surface by scanning it with a highenergy beam of electrons. They work on the basis where the electrons interact with the atoms of the sample, thus signals are produced that contain information about the samples surface composition, topography and other properties such as electrical conductivity (AWWA, 1988).

Scanning electron microscopy has been extensively used to provide more information about fouling layer formation and morphology (Basile and Charcosset, 2015; de Roever and Huisman, 2007; Fernandez-Álvarez et al., 2010; Malaeb and Ayoub, 2011). Optical microscopy can be used to directly observation of the fouling morphology and identify many foulants by their colour, size, crystalline structure, or other characteristic. Well-known examples of foulants thatcan be recognized by optical microscopy are iron oxide by its colour, size, and agglomerate nature and bacteria by their shape, size, and movement (de Roever and Huisman, 2007; Sachitand Veenstra, 2017). Meng et al. (2010) used SEM technic to visualise the morphology of fouling on polymeric MF membranes applied in membrane bioreactors (MBRs).

\subsubsection{SEM-energy-dispersive spectrophotometry (EDX)}

SEM coupled with Energy-Dispersive X-ray analysis (SEM-EDX) works on the basis that the electron beam interacts with the atoms in the sample, causing inner electron shell transitions, thus emitting $\mathrm{X}$-rays which are collected and analysed by the EDX analyser (Willis and Conner, 2015).

SEM-EDX has been widely used to characterize and provide information on the mineral fouling on organic membranes, in addiction, allows a semi-quantitative analysis of the elemental chemical composition of the fresh and fouled membrane (Malaeb and Ayoub, 2011; Nghiem et al., 2006).

Rabiller-Baudry et al. (2012) investigated organic fouling on porous organic composite membranes fouled with skim milk by the use of scanning electron microscopy (SEM) coupled to Energy-Dispersive X-ray spectroscopy (EDX) micro-analysis. Van Hoof et al. (2002) and Vrouwenvelder et al. (2011) analysed RO membranes fouling by autopsy and found that foulants layer were made of about $50-60 \%$ biofilm and the complement mainly corresponds to inorganic elements as $\mathrm{Fe}, \mathrm{Al}, \mathrm{Ca}, \mathrm{Mg}$, Si. 


\subsubsection{Optical coherence tomography (OCT)}

Optical coherence tomography (OCT) has been used to characterize membrane fouling in recent studies. However, no one study applying OCT to the characterization of the membrane fouling by dissolved and colloidal substances (DCS) from a secondary clarifier effluent from a wastewater treatment plant (WWTP) in a papermaking factory is available to the date 
Table 2-9 - Summary comparing analytical techniques for foulant identification and characterization of membrane fouling. Addapted from (Chen et al., 2018).

\begin{tabular}{|c|c|c|c|}
\hline Approach & Feasibilities & Advantages & Limitations \\
\hline $\begin{array}{l}\text { Fluorescence } \\
\text { spectroscopy }\end{array}$ & $\begin{array}{l}\text { Detection of fluorescent organic } \\
\text { compounds in foulants. }\end{array}$ & $\begin{array}{l}\text { Nondestructive and sensitive analysis } \\
\text { of NOM, DCS and EPS components }\end{array}$ & $\begin{array}{llr}\text { Sample should } & \text { be soluble, } & \text { and } \\
\text { nonfluorescent } & \text { compounds } & \text { as } \\
\text { polysaccharides } & \text { (cellulosic species), fatty } \\
\text { and resin acid are not detectable. }\end{array}$ \\
\hline ATR-FTIR & $\begin{array}{l}\text { Detection of functional groups in } \\
\text { fouling layer on fouled membranes. } \\
\text { Provide an easy and interpretable } \\
\text { overview of fouling distribution. }\end{array}$ & $\begin{array}{l}\text { Differentiation of foulants through } \\
\text { fingerprint spectral analysis }\end{array}$ & $\begin{array}{l}\text { Water content strongly affects the } \\
\text { measurement and difficult precision in the } \\
\text { quantitative analysis. }\end{array}$ \\
\hline FESEM & $\begin{array}{l}\text { Imaging of membrane structure and } \\
\text { foulants. }\end{array}$ & $\begin{array}{l}\text { Directly observation of the fouling } \\
\text { morphology }\end{array}$ & $\begin{array}{l}\text { Dehydration is needed, and spatial resolution } \\
\text { is limited. }\end{array}$ \\
\hline EDS & $\begin{array}{l}\text { Information on the elemental } \\
\text { inorganic foulants }\end{array}$ & $\begin{array}{l}\text { A quite easy task considering that the } \\
\text { inorganic elements which are looked for } \\
\text { usually are present on membrane } \\
\text { surface. }\end{array}$ & \\
\hline OCT & $\begin{array}{l}\text { 3D imaging of fouling layer (spatial } \\
\text { and temporal resolution). }\end{array}$ & $\begin{array}{l}\text { Highly sensitive, optical sectioning and, } \\
\text { qualitative and quantitative analysis of } \\
\text { the fouling layer }\end{array}$ & \\
\hline SUVA & $\begin{array}{l}\text { Comparison of aromaticity, molecular } \\
\text { weight distribution, indication of the } \\
\text { presence of unsaturated organic } \\
\text { compounds (hydrophobicity or } \\
\text { hydrophilicity). }\end{array}$ & Simple and versatile & $\begin{array}{l}\text { Sample should be soluble, and the spectra } \\
\text { are usually highly overlapping and need } \\
\text { further validation. }\end{array}$ \\
\hline
\end{tabular}




\section{$2.7 \quad$ References}

Ahmad, A., Wong, S., Teng, T., Zuhairi, A., 2008. Improvement of alum and PACl coagulation by polyacrylamides (PAMs) for the treatment of pulp and paper mill wastewater. Chemical Engineering Journal 137, 510-517. https://doi.org/10.1016/j.cej.2007.03.088

Ahn, W.-Y., Kalinichev, A.G., Clark, M.M., 2008. Effects of background cations on the fouling of polyethersulfone membranes by natural organic matter: Experimental and molecular modeling study. Journal of Membrane Science 309, 128-140. https://doi.org/10.1016/j.memsci.2007.10.023

Al-Amoudi, A., Lovitt, R.W., 2007. Fouling strategies and the cleaning system of NF membranes and factors affecting cleaning efficiency. Journal of Membrane Science 303, 4-28. https://doi.org/10.1016/j.memsci.2007.06.002

Ali, A., Hashmi, H.N., Baig, N., 2013. TREATMENT OF THE PAPER MILL EFFLUENT - A REVIEW. International Journal Of Engineering 4.

Ali, A., Hashmi, H.N., Q, I.A., 2010. Effects of Methanol on the Treatability of Black Liquor using UASB Reactor. 16, 42-46. https://doi.org/10.3126/hn.v6i0.4193

Angione, M.D., Duff, T., Bell, A.P., Stamatin, S.N., Fay, C., Diamond, D., Scanlan, E.M., Colavita, P.E., 2015. Enhanced Antifouling Properties of Carbohydrate Coated Poly(ether sulfone) Membranes. ACS Applied Materials \& Interfaces 7, 17238-17246. https://doi.org/10.1021/acsami.5b04201

Arshad, A., Hashim, N.H., Ghazala, N., 2011. Usage of UASB Reactor to Assess Feasibility of Treatment of Paper Mill Effluent. 1 28, 103-114. https://doi.org/10.29037/ajstd.37

Ashrafi, O., Yerushalmi, L., Haghighat, F., 2015. Wastewater treatment in the pulpand-paper industry: A review of treatment processes and the associated greenhouse gas emission. Journal of Environmental Management 158, 146157. https://doi.org/10.1016/j.jenvman.2015.05.010

Assalin, M.R., dos Santos Almeida, E., Durán, N., 2009. Combined System of Activated Sludge and Ozonation for the Treatment of Kraft E1 Effluent. Int J Environ Res Public Health 6, 1145-1154. https://doi.org/10.3390/ijerph6031145 
Avşar, E., Demirer, G.N., 2008. Cleaner production opportunity assessment study in SEKA Balikesirpulp and paper mill. Journal of Cleaner Production 16, 422431. https://doi.org/10.1016/j.jclepro.2006.07.042

Azami, H., Sarrafzadeh, M.H., Mehrnia, M.R., 2012. Soluble microbial products (SMPs) release in activated sludge systems: a review. Iranian J Environ Health Sci Eng 9, 30. https://doi.org/10.1186/1735-2746-9-30

AWWA, 1988. Journal - American Water Works Association: List of Issues - Wiley Online Library [WWW Document]. URL https://awwa.onlinelibrary.wiley.com/loi/15518833/year/1998 (accessed 2.5.19).

Banti, D., Mitrakas, M., Fytianos, G., Tsali, A., Samaras, P., 2020. Combined Effect of Colloids and SMP on Membrane Fouling in MBRs. Membranes 10, 118. https://doi.org/10.3390/membranes 10060118

Baek, S.-O., Chang, I.-S., 2009. Pretreatments to control membrane fouling in membrane filtration of secondary effluents. Desalination 244, 153-163. https://doi.org/10.1016/j.desal.2008.04.043

Bajpai, P., 2015. Pulp and paper industry : microbiological issues in papermaking., 5th ed. Elsevier.

Bajpai, P., 2012. Biotechnology for Pulp and Paper Processing. Springer US.

Bajpai, P., 2000. Treatment of Pulp \& Paper Mill Effluents with Anaerobic Technology. Pira International, Leatherhead.

Baker, A., Spencer, R.G.M., 2004. Characterization of dissolved organic matter from source to sea using fluorescence and absorbance spectroscopy. Science of The Total Environment 333, 217-232. https://doi.org/10.1016/j.scitotenv.2004.04.013

Basile, A., Charcosset, C., 2015. Integrated Membrane Systems and Processes. John Wiley \& Sons.

Beril Gönder, Z., Arayici, S., Barlas, H., 2011. Advanced treatment of pulp and paper mill wastewater by nanofiltration process: Effects of operating conditions on membrane fouling. Separation and Purification Technology 76, 292-302. https://doi.org/10.1016/j.seppur.2010.10.018 
Beyer, F., Laurinonyte, J., Zwijnenburg, A., Stams, A.J.M., Plugge, C.M., 2017. Membrane Fouling and Chemical Cleaning in Three Full-Scale Reverse Osmosis Plants Producing Demineralized Water [WWW Document]. Journal of Engineering. https://doi.org/10.1155/2017/6356751

Bhattacharjee, S., Datta, S., Bhattacharjee, C., 2007. Improvement of wastewater quality parameters by sedimentation followed by tertiary treatments. Desalination 212, 92-102. https://doi.org/10.1016/j.desal.2006.08.014

Bowen, W.R., Calvo, J.I., Hernández, A., 1995. Steps of membrane blocking in flux decline during protein microfiltration. Journal of Membrane Science 101, 153165. https://doi.org/10.1016/0376-7388(94)00295-A

Brião, V.B., Tavares, C.R.G., 2012. Pore blocking mechanism for the recovery of milk solids from dairy wastewater by ultrafiltration. Brazilian Journal of Chemical Engineering 29, 393-407. https://doi.org/10.1590/S0104-66322012000200019

Bryant, C.W., 2010. Updating a model of pulp and paper wastewater treatment in a partial-mix aerated stabilization basin system. Water Sci. Technol. 62, 12481255. https://doi.org/10.2166/wst.2010.934

Buzzini, A.P., Gianotti, E.P., Pires, E.C., 2005. UASB performance for bleached and unbleached kraft pulp synthetic wastewater treatment. Chemosphere 59, 5561. https://doi.org/10.1016/j.chemosphere.2004.09.102

Buzzini, A.P., Pires, E.C., 2007. Evaluation of a upflow anaerobic sludge blanket reactor with partial recirculation of effluent used to treat wastewaters from pulp and paper plants. Bioresource Technology 98, 1838-1848. https://doi.org/10.1016/j.biortech.2006.06.030

C. Jacquin, C., Teychene, B., Lemee, L., Lesage, G., Heran, M., 2018. Characteristics and fouling behaviors of Dissolved Organic Matter fractions in a full-scale submerged membrane bioreactor for municipal wastewater treatment. $\begin{array}{llll}\text { Biochemical Engineering Journal 169-181. } & \text { 132, }\end{array}$ https://doi.org/10.1016/j.bej.2017.12.016

Cai, F., Lei, L., Li, Y., 2019. Differentbioreactors for treating secondary effluentfrom recycled paper mill. Science of The Total Environment 667, 49-56. https://doi.org/10.1016/j.scitotenv.2019.02.377 
Carbonell-Alcaina, C., Corbatón-Báguena, M.-J., Álvarez-Blanco, S., Bes-Piá, M.A., Mendoza-Roca, J.A., Pastor-Alcañiz, L., 2016. Determination of fouling mechanisms in polymeric ultrafiltration membranes using residual brines from table olive storage wastewaters as feed. Journal of Food Engineering 187, 14 23. https://doi.org/10.1016/j.jfoodeng.2016.04.016

Carlsson, D.J., Dal-Cin, M.M., Black, P., Lick, C.N., 1998. A surface spectroscopic study of membranes fouled by pulp mill ef ${ }^{-}$uent. Journal of Membrane Science 11.

Carrère, H., Blaszkow, F., Balmann, H.R. de, 2001. Modelling the clarification of lactic acid fermentation broths by cross-flow microfiltration. Journal of Membrane Science 186, 219-230. https://doi.org/10.1016/S03767388(00)00677-3

Carstea, E.M., Bridgeman, J., Baker, A., Reynolds, D.M., 2016. Fluorescence spectroscopy for wastewater monitoring: A review. Water Research 95, 205219. https://doi.org/10.1016/j.watres.2016.03.021

Catalkaya, E.C., Kargi, F., 2008. Advanced oxidation treatment of pulp mill effluent for TOC and toxicity removals. Journal of Environmental Management 87, 396404. https://doi.org/10.1016/j.jenvman.2007.01.016

Chen, C., Mao, S., Wang, J., Bao, J., Xu, H., Su, W., Dai, H., 2015. Application of Ultrafiltration in a Paper Mill: Process Water Reuse and Membrane Fouling Analysis. BioResources $10, \quad$ 2376-2391. https://doi.org/10.15376/biores.10.2.2376-2391

Chen, D., Weavers, L., Walker, H., Lenhart, J., 2006. Ultrasonic control of ceramic membrane fouling caused by natural organic matter and silica particles. Jou mal of Membrane Science 276, 135-144. https://doi.org/10.1016/j.memsci.2005.09.039

Chen, W., Horan, N.J., 1998. The Treatment of a High Strength Pulp and Paper Mill Effluent for Wastewater Re-Use. Environmental Technology 19, 163-171. https://doi.org/10.1080/09593330.1998.9618627 
Chen, W., Qian, C., Zhou, K.-G., Yu, H.-Q., 2018. Molecular Spectroscopic Characterization of Membrane Fouling: A Critical Review. Chem 4, 1492-1509. https://doi.org/10.1016/j.chempr.2018.03.011

Chen, W., Westerhoff, P., Leenheer, J.A., Booksh, K., 2003b. Fluorescence Excitation-Emission Matrix Regional Integration to Quantify Spectra for Dissolved Organic Matter. Environmental Science \& Technology 37, 57015710. https://doi.org/10.1021/es034354c

Chen, Y., Zhan, H., Chen, Z., Fu, S., 2003. Study on the treatment of the sulfite pulp $\mathrm{CEH}$ bleaching effluents with the coagulation-anaerobic acidification-aeration package reactor. Water Research 37, 2106-2112. https://doi.org/10.1016/S0043-1354(02)00599-7

Choi, H., Zhang, K., Dionysiou, D.D., Oerther, D.B., Sorial, G.A., 2005. Influence of cross-flow velocity on membrane performance during filtration of biological suspension. Journal of Membrane Science 248, 189-199. https://doi.org/10.1016/j.memsci.2004.08.027

Choi, S.-W., Yoon, J.-Y., Haam, S., Jung, J.-K., Kim, J.-H., Kim, W.-S., 2000. Modeling of the Permeate Flux during Microfiltration of BSA-Adsorbed Microspheres in a Stirred Cell. Journal of Colloid and Interface Science 228, 270-278. https://doi.org/10.1006/jcis.2000.6940

Chudacek, M.W., Fane, A.G., 1984. The dynamics of polarisation in unstirred and stirred ultrafiltration. Journal of Membrane Science 21, 145-160. https://doi.org/10.1016/S0376-7388(00)81551-3

Coble, P., Lead, J., Baker, A., Reynolds, D., Spencer, R.G.M. (Eds.), 2014. Aquatic Organic Matter Fluorescence, 1 edition. ed. Cambridge University Press.

Coble, P.G., 1996. Characterization of marine and terrestrial DOM in seawater using excitation-emission matrix spectroscopy. Marine Chemistry 51, 325-346. https://doi.org/10.1016/0304-4203(95)00062-3

Corbatón-Báguena, M.-J., Álvarez, S., Vincent-Vela, M.-C., 2017. Ultrafiltration of whey: membrane performance and modelling using a combined pore blockingcake formation model. Journal of Chemical Technology \& Biotechnology 93. https://doi.org/10.1002/jctb.5446 
Corbatón-Báguena, M.-J., Álvarez-Blanco, S., Vincent-Vela, M.-C., 2015. Fouling mechanisms of ultrafiltration membranes fouled with whey model solutions. Desalination 360, 87-96. https://doi.org/10.1016/j.desal.2015.01.019

Crozes, G., Anselme,C., Mallevialle,J., 1993. Effect of adsorption of organic matter on fouling of ultrafiltration membranes. Journal of Membrane Science 84, 6177. https://doi.org/10.1016/0376-7388(93)85051-W

Davis, R.H., 1992. Modeling of Fouling of Crossflow Microfiltration Membranes. Separation and Purification Methods 21, 75-126. https://doi.org/10.1080/03602549208021420

de Barros, S.T.D., Andrade, C.M.G., Mendes, E.S., Peres, L., 2003. Study of fouling mechanism in pineapple juice clarification by ultrafiltration. Journal of Membrane Science 215, 213-224. https://doi.org/10.1016/S03767388(02)00615-4

de Roever, E.W.F., Huisman, I.H., 2007. Microscopy as a tool for analysis of membrane failure and fouling. Desalination 207, 35-44. https://doi.org/10.1016/j.desal.2006.08.002

Delaunay, D., Rabiller-Baudry, M., Gozálvez-Zafrilla, J.M., Balannec, B., Frappart, M., Paugam, L., 2008. Mapping of protein fouling by FTIR-ATR as experimental tool to study membrane fouling and fluid velocity profile in various geometries and validation by CFD simulation. Chemical Engineering and Processing: Process Intensification, Euromembrane 2006 47, 1106-1117. https://doi.org/10.1016/j.cep.2007.12.008

Diez, M.C., Castillo, G., Aguilar, L., Vidal, G., Mora, M.L., 2002. Operational factors and nutrient effects on activated sludge treatment of Pinus radiata kraft mill wastewater. Bioresour. Technol. 83, 131-138.

Ebrahim, S., El-Dessouky,H., 1994. Evaluation of chemical cleaning agents for sea water reverse osmosis membranes. Desalination 99, 169-188. https://doi.org/10.1016/0011-9164(94)00126-X

ElHadidy, A., 2016. Performance of Biological Filters for Drinking Water Treatment and Their Use for High Pressure Membrane Biofouling Control. 
EISergany, M., Ahsan, A., A. Aziz, Md.M., 2015. Optimizing the Performance of a Paper Mill Effluent Treatment. Sains Malaysiana 44, 101-106. https://doi.org/10.17576/jsm-2015-4401-14

Erkan, H.S., Engin, G.O., 2017. The investigation of paper mill industry wastewater treatment and activated sludge properties in a submerged membrane bioreactor. Water Sci. Technol. 76, 1715-1725. https://doi.org/10.2166/wst.2017.351

Fathallah, Z., Elkharrim, K., Ayyach, A., Fathallah, R., Hbaiz, E.M., Hamid, C., Elkhadmaoui, A., Belghyti, D., 2014. CHARACTERIZATION OF INDUSTRIAL WASTEWATER TREATED BY NATURAL LAGOON (PAPER MILL IN SIDI YAHIA GHARB, MOROCCO). International Journal of Innovation and Applied Studies 7, 1363-1370.

Fernandez-Álvarez, G., Garralón, G., Plaza, F., Garralón, A., Pérez, J., Gómez, M.A., 2010. Autopsy of SWRO membranes from desalination plant in Ceuta after 8years in operation. Desalination 263, 264-270. https://doi.org/10.1016/j.desal.2010.06.068

Field, R.W., Wu, D., Howell, J.A., Gupta, B.B., 1995. Critical flux concept for microfiltration fouling. Journal of Membrane Science 100, 259-272. https://doi.org/10.1016/0376-7388(94)00265-Z

Figoli, A., Criscuoli, A. (Eds.), 2017. Sustainable Membrane Technology for Water and Wastewater Treatment, Green Chemistry and Sustainable Technology. Springer Singapore.

Gao, W., Liang, H., Ma, J., Han, M., Chen, Z., Han, Z., Li, G., 2011. Membrane fouling control in ultrafiltration technology for drinking water production: $A$ review. Desalination 272, 1-8. https://doi.org/10.1016/j.desal.2011.01.051

García-Fayos, B., Arnal, J.M., Sancho, M., 2012. Cleaning of ultrafiltration membranes after the treatment of surface water: Static-dynamic test. Desalination and Water Treatment - DESALIN WATER TREAT 51, 1-8. https://doi.org/10.1080/19443994.2012.704687

Gelaw, T.K., Güell, C., Ferrando, M., De Lamo-Castellví, S., 2014. Use of attenuated total reflectance infrared microspectroscopy combined with 
multivariate analysis to study membrane fouling. Journal of Food Engineering 143, 69-73. https://doi.org/10.1016/j.jfoodeng.2014.06.032

Ghoreishi, S.M., Haghighi, M.R., 2007. Chromophores removal in pulp and paper mill effluent via hydrogenation-biological batch reactors. Chemical Engineering Journal 127, 59-70. https://doi.org/10.1016/j.cej.2006.09.022

Gönder, Z.B., Arayici, S., Barlas, H., 2012. Treatment of Pulp and Paper Mill Wastewater Using Utrafiltration Process: Optimization of the Fouling and Rejections. Industrial \& Engineering Chemistry Research 51, 6184-6195. https://doi.org/10.1021/ie2024504

Graff, M., 2012. 10 - Disposal of metalworking fluids, in: Astakhov, V.P., Joksch, S. (Eds.), Metalworking Fluids (MWFs) for Cutting and Grinding, Woodhead Publishing Series in Metals and Surface Engineering. Woodhead Publishing, pp. 389-402. https://doi.org/10.1533/9780857095305.389

Gupta, A., Gupta, R., 2019. Treatment and Recycling of Wastewater from Pulp and Paper Mill, in:Singh, R.L., Singh, R.P. (Eds.), Advances in Biological Treatment of Industrial Waste Water and Their Recycling for a Sustainable Future, Applied Environmental Science and Engineering for a Sustainable Future. Springer, Singapore, pp. 13-49. https://doi.org/10.1007/978-981-13-1468-1_2

Haq, I., Raj, A., 2020. Pulpand Paper Mill Wastewater: Ecotoxicological Effects and Bioremediation Approaches for Environmental Safety, in: Bharagava, R.N., Saxena, G. (Eds.), Bioremediation of Industrial Waste for Environmental Safety: Volume II: Biological Agents and Methods for Industrial Waste Management. Springer, Singapore, pp. 333-356. https://doi.org/10.1007/978-981-13-34269_14

Hashaikeh, R., Lalia, B.S., Kochkodan, V., Hilal, N., 2014. A novel in situ membrane cleaning method using periodic electrolysis. Journal of Membrane Science 471, 149-154. https://doi.org/10.1016/j.memsci.2014.08.017

Hassana, S.R., Zwaina, H.M., Zamana, N.Q., Dahlanb, I., 2014. Recycled paper mill effluent treatment in a modified anaerobic baffled reactor: start-up and steady-state performance. Environ Technol 35, 294-299. https://doi.org/10.1080/09593330.2013.827222 
Hendriks, E., 2007. Water Soft Path Application in Industrial Systems: (Thesis requirement for the degree of Master of Environmental Studies in Environment and Resource Studies). University of Waterloo, Waterloo, Ontario, Canada.

Her, N., Amy, G., Park, H.-R., Song, M., 2004. Characterizing algogenic organic matter (AOM) and evaluating associated NF membrane fouling. Water Research 38, 1427-1438. https://doi.org/10.1016/j.watres.2003.12.008

Hermia, J., 1982. Constant Pressure Blocking Filtration Laws - Application To Power-law Non-newtonian Fluids. Institution of Chemical Engineers. Transactions 60, 183.

Howe, K.J., Ishida, K.P., Clark, M.M., 2002. Use of ATR/FTIR spectrometry to study fouling of microfiltration membranes by natural waters. Desalination 147, $251-$ 255. https://doi.org/10.1016/S0011-9164(02)00545-3

Huang, H., Schwab, K., Jacangelo, J.G., 2009. Pretreatment for Low Pressure Membranes in Water Treatment: A Review. Environ. Sci. Technol. 43, 30113019. https://doi.org/10.1021/es802473r

Hubbe, M.A., Metts, J.R., Hermosilla, D., Blanco, M.A., Yerushalmi, L., Haghighat, F., Lindholm-Lehto, P., Khodaparast, Z., Kamali, M., Elliott, A., 2016. Wastewater Treatment and Reclamation: A Review of Pulp and Paper Industry Practices and Opportunities. BioResources 11, 7953-8091-8091. https://doi.org/10.15376/biores.11.3.Hubbe

Hubbe, M.A., Sundberg, A., Mocchiutti, P., Ni, Y., Pelton, R., 2012. DISSOLVED AND COLLOIDAL SUBSTANCES (DCS) AND THE CHARGE DEMAND OF PAPERMAKING PROCESS WATERS AND SUSPENSIONS: A REVIEW. BioResources 7, 6109-6193. https://doi.org/10.15376/biores.7.4.6109-6193

Hudson, N., Baker, A., Reynolds, D., 2007. Fluorescence analysis of dissolved organic matter in natural, waste and polluted waters-a review. River Research and Applications 23, 631-649. https://doi.org/10.1002/rra.1005

Hudson, N., Baker, A., Ward, D., Reynolds, D.M., Brunsdon, C., Carliell-Marquet, C., Browning, S., 2008. Can fluorescence spectrometry be used as a surrogate for the Biochemical Oxygen Demand (BOD) test in water quality assessment? 
An example from South West England. Science of The Total Environment 391, 149-158. https://doi.org/10.1016/j.scitotenv.2007.10.054

Hwang, K.-J., Lin, T.-T., 2002. Effect of morphology of polymeric membrane on the performance of cross-flow microfiltration. Journal of Membrane Science 199, 41-52. https://doi.org/10.1016/S0376-7388(01)00675-5

Jacob, J., Prádanos, P., Calvo, J.I., Hernández, A., Jonsson, G., 1998. Fouling kinetics and associated dynamics of structural modifications. Colloids and Surfaces A: Physicochemical and Engineering Aspects 138, 173-183. https://doi.org/10.1016/S0927-7757(97)00082-4

Jarma, Y.A., Parlar, I., O. Pek, T., Kayral, K., Kabay, N., Ö. Yiğit, N., Kitiş, M., Yüksel, M., 2018. Study on Operational Conditions to Minimize Membrane Fouling in Membrane Bioreactor (MBR) System for Wastewater TreatmentPreliminary Pilot Tests. Journal of Membrane Science and Research 4, $212-$ 217. https://doi.org/10.22079/jmsr.2018.81330.1177

Jensen, J.K., Rubio, J.M.A., Engelsen, S.B., van den Berg, F., 2015. Protein residual fouling identification on UF membranes using ATR-FT-IR and multivariate curve resolution. Chemometrics and Intelligent Laboratory Systems 144, 39-47. https://doi.org/10.1016/j.chemolab.2015.03.006

Kamali, M., Gameiro, T., Costa, M.E.V., Capela, I., 2016. Anaerobic digestion of pulp and paper mill wastes - An overview of the developments and improvement opportunities. Chemical Engineering Journal 298, 162-182. https://doi.org/10.1016/j.cej.2016.03.119

Kamali, M., Khodaparast, Z., 2015. Review on recent developments on pulp and paper mill wastewater treatment. Ecotoxicology and Environmental Safety 114, 326-342. https://doi.org/10.1016/j.ecoenv.2014.05.005

Khan, M.Md.T., Takizawa, S., Lewandowski, Z., Jones, W.L., Camper, A.K., Katayama, H., Kurisu, F., Ohgaki, S., 2011. Membrane fouling due to dynamic particle size changes in the aerated hybrid PAC-MF system. Journal of Membrane Science 371, 99-107. https://doi.org/10.1016/j.memsci.2011.01.017

Khan, S.J., Hankins, N.P., Shen, L.-C., 2016. Chapter 11 - Submerged and Attached Growth Membrane Bioreactors and Forward Osmosis Membrane 
Bioreactors for Wastewater Treatment, in: Hankins, N.P., Singh, R. (Eds.), Emerging Membrane Technology for Sustainable Water Treatment. Elsevier, Boston, pp. 277-296. https://doi.org/10.1016/B978-0-444-63312-5.00011-5

Kirwan, M.J., 2011. Paper and Paperboard Packaging, in: Food and Beverage Packaging Technology. John Wiley \& Sons, Ltd, pp. 213-250. https://doi.org/10.1002/9781444392180.ch8

Koĺtuniewicz, A.B., Field, R.W., 1996. Process factors during removal of oil-in-water emulsions with cross-flow microfiltration. Desalination, Proceedings of the 1st Symposium of the European Desalination Society "Desalination for Europe" 105, 79-89. https://doi.org/10.1016/0011-9164(96)00061-6

Kumar R, R., K, S., 2014. Treatment of Paper and Pulp Mill Effluent using Sequential Batch Reactor, in: International Conference on Biological, Civil and Environmental Engineering (BCEE-2014) March 17-18, 2014 Dubai (UAE). Presented at the International Conference on Biological, Civil and Environmental Engineering, International Institute of Chemical, Biological \& Environmental Engineering. https://doi.org/10.15242/IICBE.C0314018

Lamminen, M.O., Walker, H.W., Weavers, L.K., 2004. Mechanisms and factors influencing the ultrasonic cleaning of particle-fouled ceramic membranes. Journal of Membrane Science 237, 213-223. https://doi.org/10.1016/j.memsci.2004.02.031

Lee, A., Elam, J.W., Darling, S.B., 2016. Membrane materials for water purification: design, development, and application. Environ. Sci.: Water Res. Technol. 2, 1742. https://doi.org/10.1039/C5EW00159E

Li, Q., Elimelech, M., 2004. Organic Fouling and Chemical Cleaning of Nanofiltration Membranes: Measurements and Mechanisms. Environ. Sci. Technol. 38, 4683-4693. https://doi.org/10.1021/es0354162

Li, S., 2011. A New Concept of Ultrafiltration Fouling Control: Backwashing with Low lonic Strength Water.

Liua, G., Liu, Y., Shib, H., Qianb, Y., 2004. Treatability of krafi spent liquor by microfiltration and ultrafiltration 11. 
Liu, H., Li, M., Zhu, K., Ma, H., Wu, Y., Wang, Z., Wang, S., 2020. Analysis of Dissolved and Colloidal Substances in Old Corrugated Containers' Whitewater and Dissolved Substances' Impact on Colloidal Substances' Stability. BioResources 15, 6668-6679.

Liu, Q., Yao, Y., Xu, D., 2020. Mechanism of Membrane Fouling Control by HMBR: Effect of Microbial Community on EPS. Int J Environ Res Public Health 17. https://doi.org/10.3390/ijerph17051681

Ma, D., Meng, Y., Xia, C., Gao, B., Wang, Y., 2015. Fractionation, characterization and C-, N-disinfection byproductformation of soluble microbial products in MBR processes. Bioresource Technology 198, 380-387. https://doi.org/10.1016/j.biortech.2015.09.043

Maartens, A., Swart, P., Jacobs, E.P., 1999. Feed-water pretreatment: methods to reduce membrane fouling by natural organic matter. Journal of Membrane Science 163, 51-62. https://doi.org/10.1016/S0376-7388(99)00155-6

Maghsoodi, M., Jacquin, C., Teychené, B., Heran, M., Tarabara, V.V., Lesage, G., Snow, S.D., 2019. Emerging investigator series: photocatalysis for MBR effluent post-treatment: assessing the effects of effluent organic matter characteristics. Environ. Sci.: Water Res. Technol. https://doi.org/10.1039/C8EW00734A

Mahadevaswamy, M., Murthy, B.M.S., Girijamma, A.R., 2004. Performance evaluation of up-flow anaerobic sludge blanket (UASB) reactor for treatment of paper mill wastewater 16, 194-198.

Malaeb, L., Ayoub, G.M., 2011. Reverse osmosis technology for water treatment: State of the art review. Desalination 267, 1-8. https://doi.org/10.1016/j.desal.2010.09.001

Mandeep, Kumar Gupta, G., Shukla, P., 2020. Insights into the resources generation from pulp and paper industry wastes: Challenges, perspectives and $\begin{array}{llll}\text { innovations. } \quad \text { Bioresource } & \text { Technology 2924, }\end{array}$ https://doi.org/10.1016/j.biortech.2019.122496

Mänttäri, M., Nuortila-Jokinen, J., Nyström, M., 1997. Evaluation of nanofiltration membranes for filtration of paper mill total effluent. Filtration \& Separation 34, 275-280. https://doi.org/10.1016/S0015-1882(97)84794-5 
Meng, F., Liao, B., Liang, S., Yang, F., Zhang, H., Song, L., 2010. Morphological visualization, componential characterization and microbiological identification of membrane fouling in membrane bioreactors (MBRs). Journal of Membrane Science 361, 1-14. https://doi.org/10.1016/j.memsci.2010.06.006

Mesquita, P.L., Aquino, S.F., Xavier, A.L.P., Silva, J.C.C. da, Afonso, R.C.F., Silva, S.Q., 2010. Soluble microbial product (SMP) characterization in bench-scale aerobic and anaerobic CSTRs under different operational conditions. Brazilian Journal of Chemical Engineering 27, 101-111. https://doi.org/10.1590/S010466322010000100009

Miao, Q., Huang, L., Chen, L., 2012. Advances in the Control of Dissolved and Colloidal Substances Present in Papermaking Processes: A Brief Review. BioResources 8. https://doi.org/10.15376/biores.8.1.1431-1455

Miao, R., Li, X., Wu, Y., Wang, P., Wang, L., Wu, G., Wang, J., Lv, Y., Liu, T., 2018. A comparison of the roles of $\mathrm{Ca} 2+$ and $\mathrm{Mg} 2+$ on membrane fouling with humic acid: Are there any differences or similarities? Journal of Membrane Science 545, 81-87. https://doi.org/10.1016/j.memsci.2017.09.063

Miranda Carreño, R., Blanco Suárez, Á., Negro Álvarez, C.M., Miranda Carreño, R., Blanco Suárez, Á., Negro Álvarez, C.M., 2009. Accumulation of dissolved and colloidal material in papermaking - Application to simulation. Chemical Engineering Journal 148, 385-393.

Möbius, C.H., Helble, A., 2004. Combined ozonation and biofilm treatment for reuse of papermill wastewaters. Water Sci. Technol. 49, 319-323.

Mohammadi, T., Kazemimoghadam, M., Saadabadi, M., 2003. Modeling of membrane fouling and flux decline in reverse osmosis during separation of oil in water emulsions. Desalination, Desalination and the Environment: Fresh Water for all 157, 369-375. https://doi.org/10.1016/S0011-9164(03)00419-3

Monte, M.C., Fuente, E., Blanco, A., Negro, C., 2009. Waste management from pulp and paper production in the European Union. Waste Management29, 293308. https://doi.org/10.1016/j.wasman.2008.02.002

Muhamad, M.H., Abdullah, S.R.S., Mohamad, A.B., Rahman, R.A., Kadhum, A.A.H., 2012. Kinetic evaluation and process performance of a pilot GAC-SBBR 
system treating recycled paper industry wastewater. Environmental Engineering and Management Journal 11, 829-839.

Muhamad, M.H., Abdullah, S.R.S., Mohamad, A.B., Rahman, R.A., Khadum, A. a. $H ., 2011$. Treatment of Adsorbable organic halides from recycled paper industry wastewater using a GAC-SBBR pilot plant system. Journal of Applied Sciences 11, 2388-2393. https://doi.org/10.3923/jas.2011.2388.2393

Mulder, J., 1996. Basic Principles of Membrane Technology, 2nd ed. Springer Netherlands.

Muthukumaran, S., Kentish, S., Lalchandani, S., Ashokkumar, M., Mawson, R., Stevens, G., Grieser, F., 2005. The optimisation of ultrasonic cleaning procedures for dairy fouled ultrafiltration membranes. Ultrasonics sonochemistry 12, 29-35. https://doi.org/10.1016/j.ultsonch.2004.05.007

Nakajima, H., 2013. Mass Transfer - Advances in Sustainable Energy and Environment Oriented Numerical Modeling. https://doi.org/10.5772/3372

Nghiem, L., Schaefer, A., Oschmann, N., 2006. Fouling in greywater recycling by direct ultrafiltration. Faculty of Engineering - Papers (Archive) 283-290. https://doi.org/10.1016/j.desal.2005.04.087

Nilsson, L. (Ed.), 2007. Cleaner production: technologies and tools for resource efficient production, The Baltic University environmental management book series. Baltic Univ. Press, Uppsala.

Norafifah, H., Noordin, M.Y., Wong, K.Y., Izman, S., Ahmad, A.N.A., 2015. A Study of Operational Factors for Reducing the Fouling of Hollow Fiber Membranes during Wastewater Filtration. Procedia CIRP, 12th Global Conference on Sustainable Manufacturing - Emerging Potentials 26, 781-785. https://doi.org/10.1016/j.procir.2014.07.082

Nuortila-Jokinen, J., 2000. Fresh Water Minimization by Membrane Filtration in the Pulp and Paper Industry. Wastewater Recycle, Reuse, and Reclamation 1, 372-382.

Nuortila-Jokinen, J., Mänttäri, M., Huuhilo, T., Kallioinen, M., Nyström, M., 2004. Water circuit closure with membrane technology in the pulp and paper industry. 
Water science and technology: a journal of the International Association on Water Pollution Research 50,217-27. https://doi.org/10.2166/wst.2004.0199

Nyanchaga, E.N., Elkanzi, M.A., 2003. Characteristic Strength and Treatability of a Recycled Paper Mill Wastewater in a UASB Reactor. Journal of Civil Engineering, JKUAT 8, 61-78-78.

Ordóñez, R., Hermosilla, D., San Pío, I., Blanco, A., 2010. Replacement of fresh water use by final effluent recovery in a highly optimized $100 \%$ recovered paper mill. Water Sci. Technol. 62, 1694-1703. https://doi.org/10.2166/wst.2010.933

Peiris, R.H., Hallé, C., Budman, H., Moresoli, C., Peldszus, S., Huck, P.M., Legge, R.L., 2010. Identifying fouling events in a membrane-based drinking water treatment process using principal component analysis of fluorescence excitation-emission matrices. Water Research 44, 185-194. https://doi.org/10.1016/j.watres.2009.09.036

Peldszus, S., Hallé, C., Peiris, R.H., Hamouda, M., Jin, X., Legge, R.L., Budman, H., Moresoli, C., Huck, P.M., 2011. Reversible and irreversible low-pressure membrane foulants in drinking water treatment: Identification by principal component analysis of fluorescence EEM and mitigation by biofiltration pretreatment. Water Research 45, 5161-5170. https://doi.org/10.1016/j.watres.2011.07.022

Pendergast, M.M., Hoek, E.M.V., 2011. A review of water treatment membrane nanotechnologies. Energy Environ. Sci. 4, 1946-1971. https://doi.org/10.1039/C0EE00541J

Percival, S.L., Yates, M.V., Williams, D.W., Chalmers, R.M., Gray, N.F., 2013. Microbiology of Waterborne Diseases: Microbiological Aspects and Risks, 2 edition. ed. Academic Press, Amsterdam.

Pérez, M., Torrades, F., García-Hortal, J.A., Domènech, X., Peral, J., 2002. Removal of organic contaminants in paper pulp treatment effluents under Fenton and photo-Fenton conditions. Applied Catalysis B: Environmental 36, 63-74. https://doi.org/10.1016/S0926-3373(01)00281-8

Persson, P.O., 2011. Cleaner Production : Strategies \&amp;amp; Technology for Environmental Protection. Industrial Ecology, KTH. 
Pihlajamäki, A., Väisänen, P., Nyström, M., 1998. Characterization of clean and fouled polymeric ultrafiltration membranes by Fourier transform IR spectroscopy-attenuated total reflection. Colloids and Surfaces A: Physicochemical and Engineering Aspects 138, 323-333. https://doi.org/10.1016/S0927-7757(96)03883-6

Pizzichini, M., Russo, C., Meo, C.D., 2005. Purification of pulp and paper wastewater, with membrane technology, for water reuse in a closed loop. Desalination, Membranes in Drinking and Industrial Water Production 178,351359. https://doi.org/10.1016/j.desal.2004.11.045

Pokhrel, D., Viraraghavan,T., 2004. Treatment of pulp and paper mill wastewatera review. Science of The Total Environment 333, 37-58. https://doi.org/10.1016/j.scitotenv.2004.05.017

Porcelli, N., Judd, S., 2010. Chemical cleaning of potable water membranes: A review. Separation and Purification Technology 71, 137-143. https://doi.org/10.1016/j.seppur.2009.12.007

Psoch, C., Schiewer, S., 2006. Direct filtration of natural and simulated river water with air sparging and sponge ball application for fouling control. Desalination 197, 190-204. https://doi.org/10.1016/j.desal.2005.11.027

Puro, L., Kallioinen, M., Mänttäri, M., Natarajan, G., C. Cameron, D., Nyström, M., 2010. Performance of $R C$ and $P E S$ ultrafiltration membranes in filtration of pulp mill process waters. Desalination 264, 249-255. https://doi.org/10.1016/j.desal.2010.06.034

Puro, L., Kallioinen, M., Mänttäri, M., Nyström, M., 2011. Evaluation of behavior and fouling potential of wood extractives in ultrafiltration of pulp and paper mill process water. Journal of Membrane Science 368, 150-158. https://doi.org/10.1016/..memsci.2010.11.032

Qi, L., Wang, H., Cheng, R., Li, G., Zhang, G., Liang, H., 2011. Effect of operation conditions on fouling of immersed ultrafiltration membrane for drinking water treatment of surface water, in: 2011 International Conference on Electric Technology and Civil Engineering (ICETCE). Presented at the 2011 International Conference on Electric Technology and Civil Engineering (ICETCE), pp. 4078-4081. https://doi.org/10.1109/ICETCE.2011.5774210 
Qu, F., Liang, H., Wang, Z., Wang, H., Yu, H., Li, G., 2012. Ultrafiltration membrane fouling by extracellular organic matters (EOM) of Microcystis aeruginosa in stationary phase: Influences of interfacial characteristics of foulants and fouling mechanisms. Water Research 46, 1490-1500. https://doi.org/10.1016/j.watres.2011.11.051

Rabiller-Baudry, M., Gouttefangeas, F., Lannic, J.L., Rabiller, P., 2012. Coupling of SEM-EDX and FTIR-ATR to (quantitatively) investigate organic fouling on porous organic composite membranes 11 .

Racar, M., Dolar, D., Kosutic, K., 2017. Chemical cleaning of flat sheet ultrafiltration membranes fouled by effluent organic matter. Separation and Purification Technology 188. https://doi.org/10.1016/j.seppur.2017.07.041

Rajkumar, K., 2016. An Evaluation of Biological Approach for the Effluent Treatment of Paper Boards Industry - An Economic Perspective. Journal of Bioremediation \& Biodegradation 7. https://doi.org/10.4172/2155-6199.1000366

Ram, C., Rani, P., Gebru, K.A., Abrha, M.G.M., 2020. Pulp and paper industry wastewater treatment: use of microbes and their enzymes. Physical Sciences Reviews 1. https://doi.org/10.1515/psr-2019-0050

Ramamurthy, P., Poole, R., Dorica, J.G., 1995. Fouling of ultrafiltration membranes during treatment of CTMP screw press filtrates. Journal of Pulp and Paper Science 21, J50-54.

Regula, C., Carretier, E., Wyart, Y., Gésan-Guiziou, G., Vincent, A., Boudot, D., Moulin, P., 2014. Chemical cleaning/disinfection and ageing of organic UF membranes: A review. Water Research 56, 325-365. https://doi.org/10.1016/j.watres.2014.02.050

Sachit, D.E., Veenstra, J.N., 2017. FoulantAnalysis of Three RO Membranes Used in Treating Simulated Brackish Water of the Iraqi Marshes. Membranes (Basel) 7. https://doi.org/10.3390/membranes 7020023

Safazadeh Haghighi, L., 2011. Determination of Fouling Mechanisms for Ultrafiltration of Oily Wastewater. University of Cincinnati. 
Sagiv, A., Semiat, R., 2010. Modeling of backwash cleaning methods for RO membranes. Desalination, Special Issue in memory of Sidney Loeb (19172008) 261, 338-346. https://doi.org/10.1016/j.desal.2010.04.054

Sahai, R., 2000. MEMBRANE SEPARATIONS | Filtration, in: Wilson, I.D. (Ed.), Encyclopedia of Separation Science. Academic Press, Oxford, pp. 1717-1724. https://doi.org/10.1016/B0-12-226770-2/05151-6

Saunamaki, R., 1997. Activated sludge plants in Finland. Water Science and Technology, Forest Industry Wastewaters V 35, 235-243. https://doi.org/10.1016/S0273-1223(96)00936-5

Scott, K., 1995. MEMBRANE MATERIALS, PREPARATION AND CHARACTERISATION, in: Scott, K. (Ed.), Handbook of Industrial Membranes. Elsevier Science, Amsterdam, pp. 187-269. https://doi.org/10.1016/B978185617233-2/50005-2

Sevimli, M., 2005. Post-Treatment of Pulp and Paper Industry Wastewater by Advanced Oxidation Processes. Ozone-science \& Engineering - OZONE-SCI ENG 27, 37-43. https://doi.org/10.1080/01919510590908968

Shao, S., Liang, H., Qu, F., Yu, H., Li, K., Li, G., 2014. Fluorescent natural organic matter fraction s responsible for ultrafiltration membrane fouling: Identification by adsorption pretreatment coupled with parallel factor analysis of excitationemission matrices. Journal of Membrane Science 464, 33-42. https://doi.org/10.1016/j.memsci.2014.03.071

Shirazi, S., Lin, C.-J., Chen, D., 2010. Inorganic fouling of pressure-driven membrane processes - A critical review. Desalination 250, 236-248. https://doi.org/10.1016/j.desal.2009.02.056

Singh, P., Thakur, I.S., 2006. Colour removal of anaerobically treated pulp and paper mill effluent by microorganisms in two steps bioreactor. Bioresource Technology 97, 218-223. https://doi.org/10.1016/j.biortech.2005.02.022

Singh, R., Hankins, N.P., 2016. Chapter 2 - Introduction to Membrane Processes for Water Treatment, in: Hankins, N.P., Singh, R. (Eds.), Emerging Membrane Technology for Sustainable Water Treatment. Elsevier, Boston, pp. 15-52. https://doi.org/10.1016/B978-0-444-63312-5.00002-4 
Smith, P.J., Vigneswaran, S., Ngo, H.H., Ben-Aim, R., Nguyen, H., 2006. A new approach to backwash initiation in membrane systems. Journal of Membrane Science 278, 381-389. https://doi.org/10.1016/j.memsci.2005.11.024

Sogaard, E., 2014. Chemistry of Advanced Environmental Purification Processes of Water: Fundamentals and Applications. Newnes.

Song, L., 1998. Flux decline in crossflow microfiltration and ultrafiltration: mechanisms and modeling of membrane fouling. Journal of Membrane Science 139, 183-200. https://doi.org/10.1016/S0376-7388(97)00263-9

Song, L., Elimelech, M., 1995. Theory of concentration polarization in crossflow filtration. J. Chem. Soc., Faraday Trans. 91, 3389-3398. https://doi.org/10.1039/FT9959103389

Sousa, M.R.S., Lora-García, J., López-Pérez, M.-F., Heran, M., 2020. Identification of Foulants on Polyethersulfone Membranes Used to Remove Colloids and Dissolved Matter from Paper Mill Treated Effluent. Water 12, 365. https://doi.org/10.3390/w12020365

Sopajaree, K., Teeratitayangkul, P., 2013. Cod removal of cardboard factory wastewater by upflow anaerobic filter.

Stressmann, M., 2008. Membrane Fouling in Constant Permeate Flux Cross-Flow Microfiltration of Biological Solutions.

Subashini, L.M., 2015. Review on Biological Treatment processes of Pulp and Paper Industry Waste Water 4, 5.

Tarazaga, C.C., Campderrós, M.E., Padilla, A.P., 2006. Physical cleaning by means of electric field in the ultrafiltration of a biological solution. Journal of Membrane Science 278, 219-224. https://doi.org/10.1016/j.memsci.2005.11.004

Temmink, H., Grolle, K., 2005. Tertiary activated carbon treatment of paper and board industry wastewater. Bioresource Technology 96, 1683-1689. https://doi.org/10.1016/j.biortech.2004.12.035

Thompson, G., Forster, C., 2003. Bulking in activated sludge plants treating paper mill wastewaters. Water Res. 37, 2636-2644. https://doi.org/10.1016/S00431354(03)00076-9 
Thompson, G., Swain, J., Kay, M., Forster, C.F., 2001. The treatment of pulp and paper mill effluent: a review. Bioresource Technology 77, 275-286. https://doi.org/10.1016/S0960-8524(00)00060-2

Tian, J., Yu, H., Shen, Y., Shi, W., Liu, D., Gao, S., Cui, F., 2015. Identification of irreversible UF membrane foulants by fluorescence excitation-emission matrix coupled with parallel factor analysis. Desalination and Water Treatment 57, 21794-21805. https://doi.org/10.1080/19443994.2015.1127783

van den Berg, G.B., Smolders, C.A., 1990. Flux decline in ultrafiltration processes. Desalination, Proceedings of the Symposium on Membrane Technology 77, 101-133. https://doi.org/10.1016/0011-9164(90)85023-4

Van Hoof, S.C.J.M., Minnery, J.G., Mack, B., 2002. Performing a membrane autopsy. Desalination Water Reuse 40-46.

Vashi, H., lorhemen, O.T., Tay, J.H., 2019. Extensive studies on the treatment of pulp mill wastewater using aerobic granular sludge (AGS) technology. Chemical Engineering Journal 359, 1175-1194. https://doi.org/10.1016/j.cej.2018.11.060

Vedavyasan, C.V., 2001. Potential use of magnetic fields - A perspective. Desalination 134, 105-108. https://doi.org/10.1016/S0011-9164(01)00120-5

Vela, M.C.V., Blanco, S.Á., García, J.L., Rodríguez, E.B., 2008. Analysis of membrane pore blocking models applied to the ultrafiltration of PEG. Separation and Purification Technology 62, 489-498. https://doi.org/10.1016/j.seppur.2008.02.028

Verband Deutscher Papierfabriken, 2017. Paper making from pulp to paper. The production line on one sheet. [WWW Document]. Paper making. URL https://www.vdp-online.de/en/home.html (accessed 3.16.19).

Vincent Vela, M.C., Álvarez Blanco, S., Lora García, J., Bergantiños Rodríguez, E., 2009. Analysis of membrane pore blocking models adapted to crossflow ultrafiltration in the ultrafiltration of PEG. Chemical Engineering Journal 149, 232-241. https://doi.org/10.1016/j.cej.2008.10.027

Vrouwenvelder, J.S., Kruith of, J., Loosdrecht, M.C.M. van, 2011. Biofouling of Spiral Wound Membrane Systems. IWA Publishing. 
Wang, F., Tarabara, V.V., 2008. Pore blocking mechanisms during early stages of membrane fouling by colloids. Journal of Colloid and Interface Science 328, 464-469. https://doi.org/10.1016/j.jcis.2008.09.028

Wang, H., Ding, A., Gan, Z., Qu, F., Cheng, X., Bai, L., Guo, S., Li, G., Liang, H., 2017. Fluorescent natural organic matter responsible for ultrafiltration membrane fouling: Fate, contributions and fouling mechanisms. Chemosphere 182, 183-193. https://doi.org/10.1016/j.chemosphere.2017.04.148

Wang, Z., Han, X., Ma, J., Wang, P., Mei, X., Wu, Z., 2013. Recent advances in membrane fouling caused by extracellularpolymeric substances: a mini-review. Desalination and Water Treatment 51, 5121-5131. https://doi.org/10.1080/19443994.2013.768403

Wang, Z., Wu, Z., Yin, X., Tian, L., 2008. Membrane fouling in a submerged membrane bioreactor (MBR) under sub-critical flux operation: Membrane foulant and gel layer characterization. Journal of Membrane Science 325, 238244. https://doi.org/10.1016/.memsci.2008.07.035

Willis, R.D., Conner, T.L., 2015. Guidelines for the Application of SEM/EDX Analytical Techniques to Particulate Matter Samples - Scholar's Choice Edition. Scholar's Choice.

Wu, F.C., Evans, R.D., Dillon, P.J., 2003. Separation and Characterization of NOM by High-Performance Liquid Chromatography and On-Line Three-Dimensional Excitation Emission Matrix Fluorescence Detection. Environ. Sci. Technol. 37, 3687-3693. https://doi.org/10.1021/es020244e

Xavier, C.R., Oñate, E., Mondaca, M.A., Vidal, G., 2011. Kraft pulp mill effluent treated by activated sludge and aerated lagoon genotoxicity assess. Interciencia 36, 412-416.

Xie, W.-M., Ni, B.-J., Sheng, G.-P., Seviour, T., Yu, H.-Q., 2016. Quantification and kinetic characterization of soluble microbial products from municipal wastewater treatment plants. Water Research 88, 703-710. https://doi.org/10.1016/j.watres.2015.10.065

Yan, L., Li, R., Song, Y., Jia, Y., Li, Z., Song, L., Zhang, H., 2019. Characterization of the Fouling Layer on the Membrane Surface in a Membrane Bioreactor: 
Evolution of the Foulants' Composition and Aggregation Ability. Membranes 9, 85. https://doi.org/10.3390/membranes9070085

Yazdanshenas, M., Soltanieh, M., Tabatabaei Nejad, S.A.R., Fillaudeau, L., 2010. Cross-flow microfiltration of rough non-alcoholic beer and diluted malt extract with tubular ceramic membranes: Investigation of fouling mechanisms. Journal of Membrane Science 362, 306-316. https://doi.org/10.1016/j.memsci.2010.06.041

Yigit, N., Civelekoglu, G., Harman, I., Koseoglu, H., Kitis, M., 2011. Effects of Various Backwash Scenarios on Membrane Fouling in a Membrane Bioreactor, in: Gökçekus, H., Türker, U., LaMoreaux, J.W. (Eds.), Survival and Sustainability: Environmental Concerns in the 21st Century, Environmental Earth Sciences. Springer Berlin Heidelberg, Berlin, Heidelberg, pp. 917-929. https://doi.org/10.1007/978-3-540-95991-5_87

Yu, H., Qu, F., Liang, H., Han, Z., Ma, J., Shao, S., Chang, H., Li, G., 2014. Understanding ultrafiltration membrane fouling by extracellular organic matter of Microcystis aeruginosa using fluorescence excitation-emission matrix coupled with parallel factor analysis. Desalination 337, 67-75. https://doi.org/10.1016/j.desal.2014.01.014

Yuan, G., Dai, H., Ye, C., Zhang, Y., Wang, Z., 2011. ADSORPTION OF Ca(II) FROM AQUEOUS SOLUTION ONTO CELLULOSIC FIBERS AND ITS IMPACT ON THE PAPERMAKING PROCESS. BioResources 6, 2790-28042804. https://doi.org/10.15376/biores.6.3.2790-2804

Yuan, W., Kocic, A., Zydney, A.L., 2002. Analysis of humic acid fouling during microfiltration using a pore blockage-cake filtration model. Journal of Membrane Science 198, 51-62. https://doi.org/10.1016/S0376-7388(01)006226

Yuan, W., Zydney, A.L., 1999. Humic acid fouling during microfiltration. Journal of Membrane Science 157, 1-12. https://doi.org/10.1016/S0376-7388(98)003299

Yuan, X., Cao, Y., Li, J., Wen, B., Zhu, W., Wang, X., Cui, Z., 2012. Effect of pretreatment by a microbial consortium on methane production of waste paper 
and cardboard. Bioresource Technology 118, 281-288. https://doi.org/10.1016/j.biortech.2012.05.058

Z. Wang, Z., Wu, Z., Tang, S., 2009. Characterization of dissolved organic matter in a submerged membrane bioreactor by using three-dimensional excitation and emission matrix fluorescence spectroscopy. Water Research 43, 1533-1540. https://doi.org/10.1016/j.watres.2008.12.033

Zaidi, A., Buisson, H., Sourirajan, S., Wood, H., 1992. Ultra- and Nano-Filtration in Advanced Effluent Treatment Schemes for Pollution Control in the Pulp and Paper Industry. Water Science and Technology 25, 263-276. https://doi.org/10.2166/wst.1992.0254

Zhang, Y., Ma, C., Ye, F., Kong, Y., Li, H., 2009. The treatment of wastewater of paper mill with integrated membrane process. Desalination 236, 349-356. https://doi.org/10.1016/j.desal.2007.10.086

Zhu, X., Wang, Z., Wu, Z., 2011. Characterization of membrane foulants in a fullscale membrane bioreactor for supermarket wastewater treatment. Process Biochemistry 46, 1001-1009. https://doi.org/10.1016/j.procbio.2011.01.020

Zoubeik, M., Salama, A., Henni, A., 2020. Table Optimization of Operating Conditions for a Superwetting Ultrafiltration $\mathrm{ZrO} 2$ Ceramic Membrane. Joumal of Environmental Engineering 146, 04020021. https://doi.org/10.1061/(ASCE)EE.1943-7870.0001670

Zularisam, A.W., Ismail, A.F., Salim, R., 2006. Behaviours of natural organic matter in membrane filtration for surface water treatment - a review. Desalination 194, 211-231. https://doi.org/10.1016/j.desal.2005.10.030

Zwain, H.M., Hassan, S.R., Zaman, N.Q., Aziz, H.A., Dahlan, I., 2013. The start-up performance of modified anaerobic baffled reactor (MABR) for the treatment of recycled paper mill wastewater. Journal of Environmental Chemical Engineering 1, 61-64. https://doi.org/10.1016/j.jece.2013.03.007 


\section{CHAPTER: GENERAL MATERIALS AND METHODS}




\subsection{Source and properties of treated effluent used as feed solution in} the UF process

The feed water for the UF membrane experiments was obtained from a secondary clarifier from a wastewater treatment plant (WWTP) in a paper mill located in the south of the Valencian autonomous region in Spain (Figure 3-1).

In this papermaking process employing recycled paper, news print and cardboard as raw materials. The WWTP has capacity of treats approximately $1.200 \mathrm{~m}^{3} /$ day of the industrial effluent with a daily biological load around $6.720 \mathrm{~kg} \mathrm{COD/d} \mathrm{using} \mathrm{BIOPAQ-}$ UASB anaerobic reactor combined with classic aerobic treatment system. The sewage first passes through anaerobic ponds and then activated sludge ponds with anoxic and aeration zones). The feed water samples were then stored in a refrigerator at $4^{\circ} \mathrm{C}$ and warmed to room temperature prior to use in the ultrafiltration experiments.

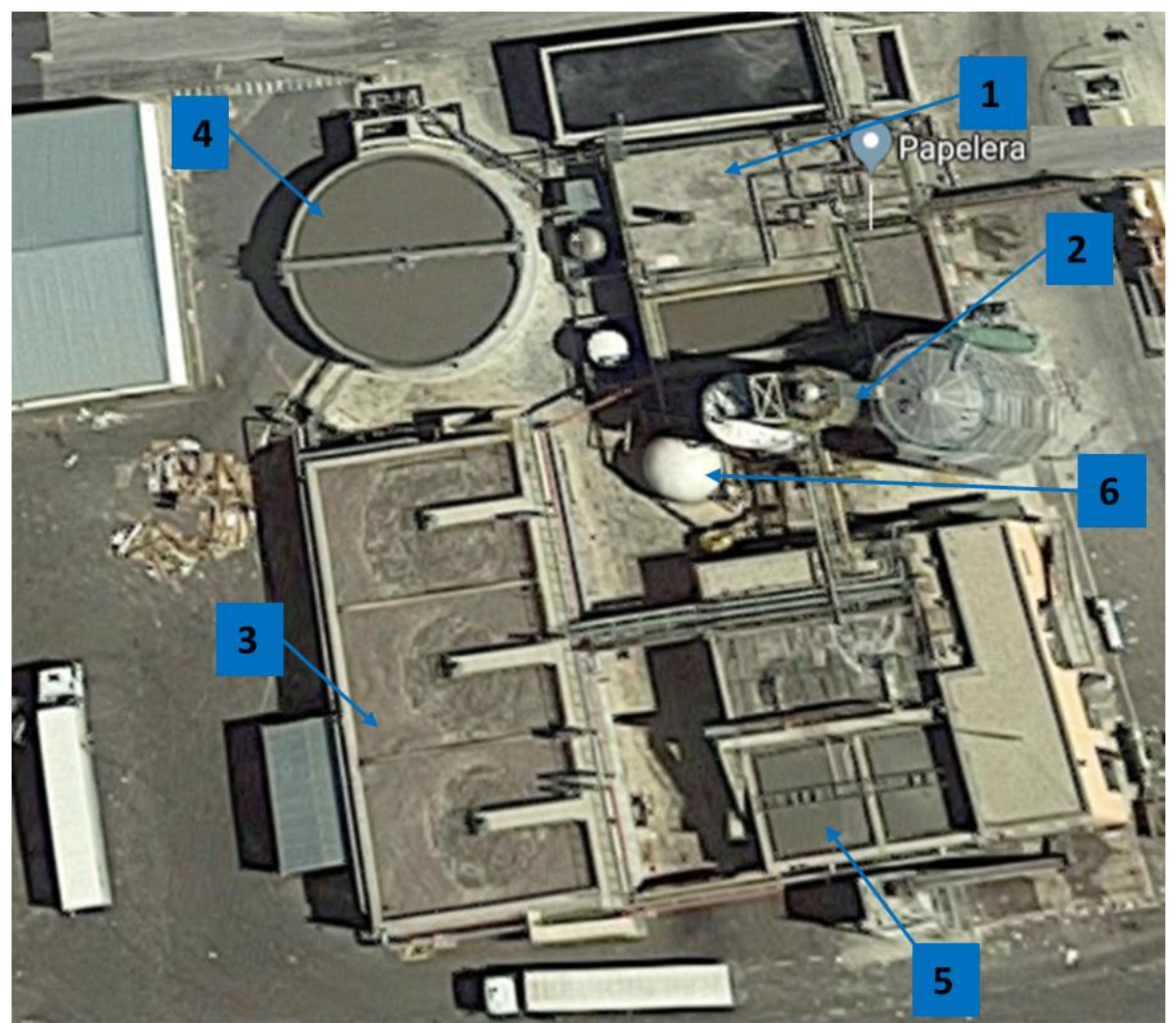

Figure 3-1 - Aerial view of the wastewater treatment plant (WWTP) in a papermaking factory. Google Maps (on-line), 2019. 
1 - Open and closed homogenization/equalization tanks (Pre-acidification step)

2 - Anaerobic biological reactors (there are 3 BIOPAQ-UASB)

3 - Aerobic biological reactor (activated sludge - after anaerobic treatment)

4 - Secondary clarifier

5 - Sludge thickening and sludge dewatering

6 - Gasometer

Average concentrations of constituents in the feed solution are summarized in Table 3-1.

Table 3-1 - Average compositions of the paper mill treated effluent (anaerobic and aerobic treatment) used in the experiments.

\begin{tabular}{|c|c|c|c|}
\hline Parameter & Units & Value & Equipment \\
\hline Turbidity & (NTU) & 39.5 & Turbidimeter D-112 - Dinko. \\
\hline $\begin{array}{l}\text { Chemical oxigen demand } \\
\qquad(\mathrm{COD})\end{array}$ & $(\mathrm{mg} / \mathrm{L})$ & $252 \pm 5.0$ & Reactor 5B-2C, COD meter. \\
\hline $\begin{array}{l}\text { Total organic carbon } \\
\text { (TOC) }\end{array}$ & $(\mathrm{mg} / \mathrm{L})$ & $80.00 \pm 2.4$ & TOC-VCSN Shimadzu Analyzer \\
\hline $\begin{array}{l}\text { Ultraviolet absorbance } \\
\qquad\left(\mathrm{UV}_{254}\right)\end{array}$ & $\left(\mathrm{cm}^{-1}\right)$ & $0.943 \pm 0.012$ & $\begin{array}{l}\text { UV-VIS Scanning spectrophotometer } \\
\text { (Unicam, UV2), with a } 1 \mathrm{~cm} \text { quartz }\end{array}$ \\
\hline SUVA & $(\mathrm{L} / \mathrm{mg} / \mathrm{m})$ & $1.114 \pm 0.03$ & cuvette. \\
\hline $\begin{array}{l}\text { Suspended solids } \\
\text { (TSS) }\end{array}$ & $(g / L)$ & $0.1986 \pm 0.05$ & $\begin{array}{l}\text { TSS Vaccum filtration assembly - } \\
\text { Alamo/Dinko. }\end{array}$ \\
\hline $\begin{array}{l}\text { Sediment solids } \\
\text { (SS) }\end{array}$ & $(\mathrm{ml} / \mathrm{L})$ & $3.5 \pm 0.1$ & $\begin{array}{l}\text { Imhoff sedimentation cone - } 1000 \mathrm{ml}- \\
\text { VITLAB. }\end{array}$ \\
\hline Conductivity & $(\mathrm{ms} / \mathrm{cm})$ & $3.56 \pm 1.0$ & $\begin{array}{l}\text { Conductivity Meter, EC-Metro GLP 31- } \\
\text { Crison. }\end{array}$ \\
\hline $\mathrm{pH}$ & & $7.8 \pm 0.5$ & pH-Meter BASIC 20 - Crison. \\
\hline Total nitrogen & $(\mathrm{mg} / \mathrm{L})$ & $1.7 \pm 0.2$ & $\begin{array}{l}\text { Thermoreactor AL125 and protometer } \\
\text { - Lovibond. }\end{array}$ \\
\hline Temperature & ${ }^{\circ} \mathrm{C}$ & $23.5 \pm 2.0$ & Temperature Meter GLP 22 -Crison. \\
\hline Particle size & $\mathrm{nm}$ & $458-1281$ & $\begin{array}{l}\text { Zetasizer Nano ZS - Malvem } \\
\text { Instruments. }\end{array}$ \\
\hline
\end{tabular}




\subsection{Analytical methods and apparatus}

\subsubsection{General characteristics}

- Turbidity:

The turbidity measurement was made using a Dinko 112 turbidimeter (ASTM D1889), which was calibrated using Dinko turbidity calibration standards before each use. Samples were measured in triplicate and the results were averaged.

- Chemical oxigen demand (COD) and Total nitrogen :

COD and total nitrogen were measured using a Merck Picco photometer at the wavelengths of $605 \mathrm{~nm}$ and a Merck TR-300 thermoreactor in accordance with the Standard Methods (D1252 - 06 ASTM and ASTM D8083, respectively) (APHA, 1998). Samples were measured in triplicate and the results were averaged.

- Total organic carbon (TOC):

Total organic carbon (TOC) is a carbon analyser used to measure directly the organic carbon (sum of the carbon particulate and DOC) content of feed and permeate samples. TOC concentrations were measured using a TOC-VCSN Shimadzu Analyzer (Shimadzu, Japan). The instrument was calibrated prior to each series of analysis using series of potassium hydrogen phthalate standards $(0.5 \mathrm{mg} / \mathrm{L}, 1 \mathrm{mg} / \mathrm{L}, 5 \mathrm{mg} / \mathrm{L}, 10$ $\mathrm{mg} / \mathrm{L}$ and $20 \mathrm{mg} / \mathrm{L}$ ). In the analyses nonpurgeable organic carbon (NPOC) determination method was employed. TOC samples were filtered through a $0.45 \mu \mathrm{m}$ filter prior to analysis and the resultants NPOC were calculated as a mean of three measurements from the TOC analyser.

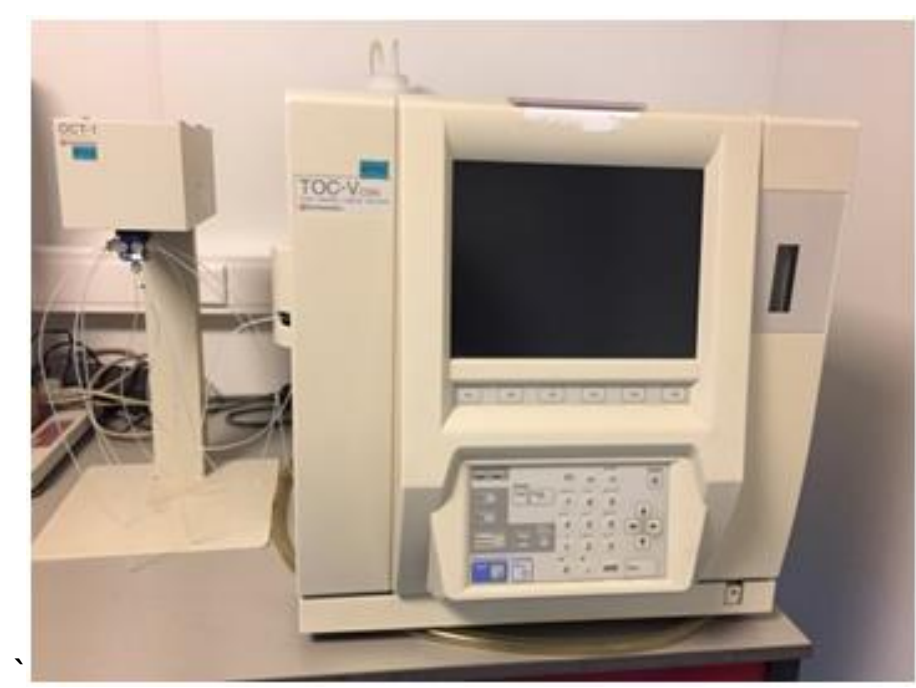


Figure 3-2 - Photograph of the setup for TOC-VCSN Shimadzu Analyzer used in the IEM.

- Specific ultraviolet (UV) absorbance (SUVA254):

The specific UV Absorbance (SUVA) is determined by the ratio of the UV absorbance measured at $254 \mathrm{~nm}$ to TOC concentration (Korshin et al., 1997; Potter and Wimsatt, 2009). SUVA was calculated according the following equation:

$$
\operatorname{SUVA}\left(\frac{L}{m \cdot m g}\right)=U V_{254}\left(m^{-1}\right) * \frac{100}{\operatorname{TOC}\left({ }^{m g} / L\right)}
$$

Equation 3-1

Where high SUVA values (more than $4 \mathrm{~L} / \mathrm{m} / \mathrm{mg}$ ) indicate high humic content with a hydrophobic character (aromatic) and low SUVA (less than $3 \mathrm{~L} / \mathrm{m} / \mathrm{mg}$ ) corresponds to the presence of mainly hydrophilic material with reduced aromatic character (Archer and Singer, 2006; Edzwald and Tobiason, 1999). Specific UV absorbance (SUVA254) was measured with a $1 \mathrm{~cm}$ quartz cuvette using a UV-VIS spectrophotometer (UV2401 PC, Shimadzu, Japan). Samples were measured in triplicate and the results were averaged.

- Total suspended solids and sediment solids

The PMTE and the membrane permeate suspended solids concentration were measured using a glass fiber filter with a $1 \mu \mathrm{m}$ pore size and a $47 \mathrm{~mm}$ diameter following a standard method of analysis (APHA-AWWA-WEF, 1998). To estimate sediment solids concentration $(\mathrm{ml} / \mathrm{L})$ the PMTE was thoroughly mixed and poured in Imhoff cone and settleable matter was measured volume-trically after 1 and $2 \mathrm{~h}$.

- Particle size distribution and zeta potential

The experimental foulants size distribution (colloids and dissolved matter), and fresh and fouled membrane surface zeta potential were measured using the dynamic lightscattering method in a Zetasizer Nano ZS instrument (Malvern Instruments), through averaging three independent sample analyses (standard deviation less than $5 \%$ ). 


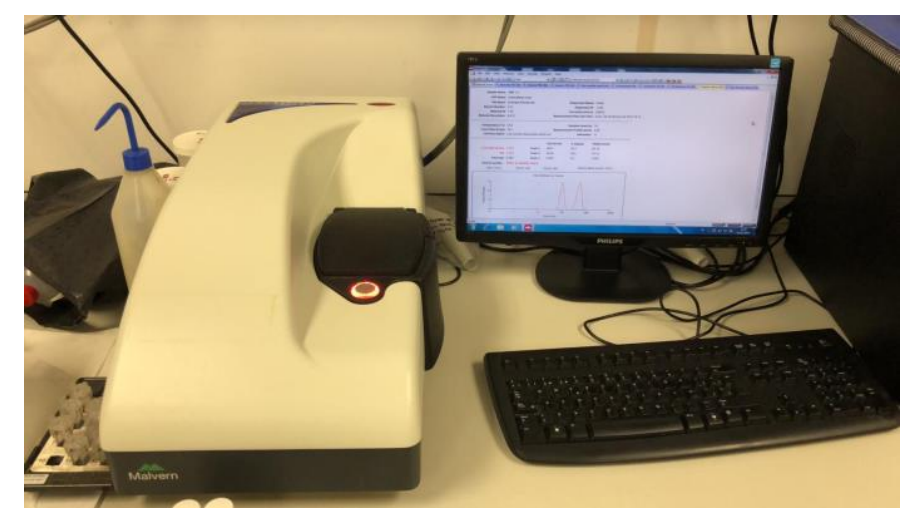

Figure 3-3 - Photograph of the setup for Zetasizer Nano ZS instrument (Malvern Instruments) used in the ISIRYM.

- Conductivity and pH

Conductivity was measured using a conductivity Meter (EC-Metro GLP 31- Crison) set WTW 3 level (ASTM D1125 - 14). Standard solutions containing potassium chloride $(\mathrm{KCl})$ at the $\mathrm{EC}$ of 500,1413 and $2760 \mu \mathrm{S} \mathrm{cm}{ }^{-1}$ were used to calibrate the conductivity meter.

The $\mathrm{pH}$ and temperature were monitored using a BASIC $20 \mathrm{pH}$-Meter (Crison), the instrument was calibrated with standard solutions of $\mathrm{pH} 4.0,7.0$, and 10.0.

Samples were measured in triplicate and the results were averaged.

\subsection{Membrane properties and characteristics}

UF experiments were carried out using polyethersulfone (PES) membranes with different molecular weight cut-offs (MWCO) of $10 \mathrm{kDa}, 50 \mathrm{kDa}$ and $100 \mathrm{kDa}$ in a flat sheet, provided by Synder Filtration ${ }^{\mathrm{TM}}$ (Vacaville, USA). These membranes have nominal pore sizes of $3.16-3.5 \mathrm{~nm}, 6.09-8.17 \mathrm{~nm}$ and 7.67-12.29 nm, respectively calculated based on the literature (Liu et al., 2003; Yoon, 2015). Table 3-2, shows the characteristics and operating conditions of the membranes used. 
Table 3-2 - Technical data on the membranes used in this study.

\begin{tabular}{cccc}
\hline \hline & \multicolumn{3}{c}{ Membrane / Cut-off } \\
\cline { 2 - 4 } & ST (PES) & MQ (PES) & LY (PES) \\
\hline \hline MWCO (kDa) & 10 & 50 & 100 \\
pH range & $2-10$ & $2-10$ & $2-10$ \\
Maximum temperature $\left({ }^{\circ} \mathrm{C}\right)$ & 55 & 55 & 55 \\
Max Inlet Pressure $(\mathrm{Bar})$ & 8.3 & 8.3 & 8.3 \\
Max Differential Pressure (bar) & 1.2 & 1.2 & 1.2 \\
Free peroxide in product during operation & $<3 \mathrm{ppm}$ & $<3 \mathrm{ppm}$ & $<3 \mathrm{ppm}$ \\
\hline \hline
\end{tabular}

New membranes were soaked overnight in Milli-Q water to remove trace quantities of preservative and to limit the introduction of organic residues into the water sample.

\subsection{Pre-treatment before the UF processes}

There are two pre-treatment setups used in this work, one for dead-end experiment and other for the cross-flow filtration.

- In the dead-end UF

As the foulant fraction between $0.45 \mu \mathrm{m}$ and $100 \mathrm{kDa}$ is the major fraction contributing to the membrane fouling (Howe et al., 2006), a pre-filtration at $0.45 \mu \mathrm{m}$ was employed on the PMTE to eliminate the larger suspended solids and higher molecular weight collides (Figure 3-4).
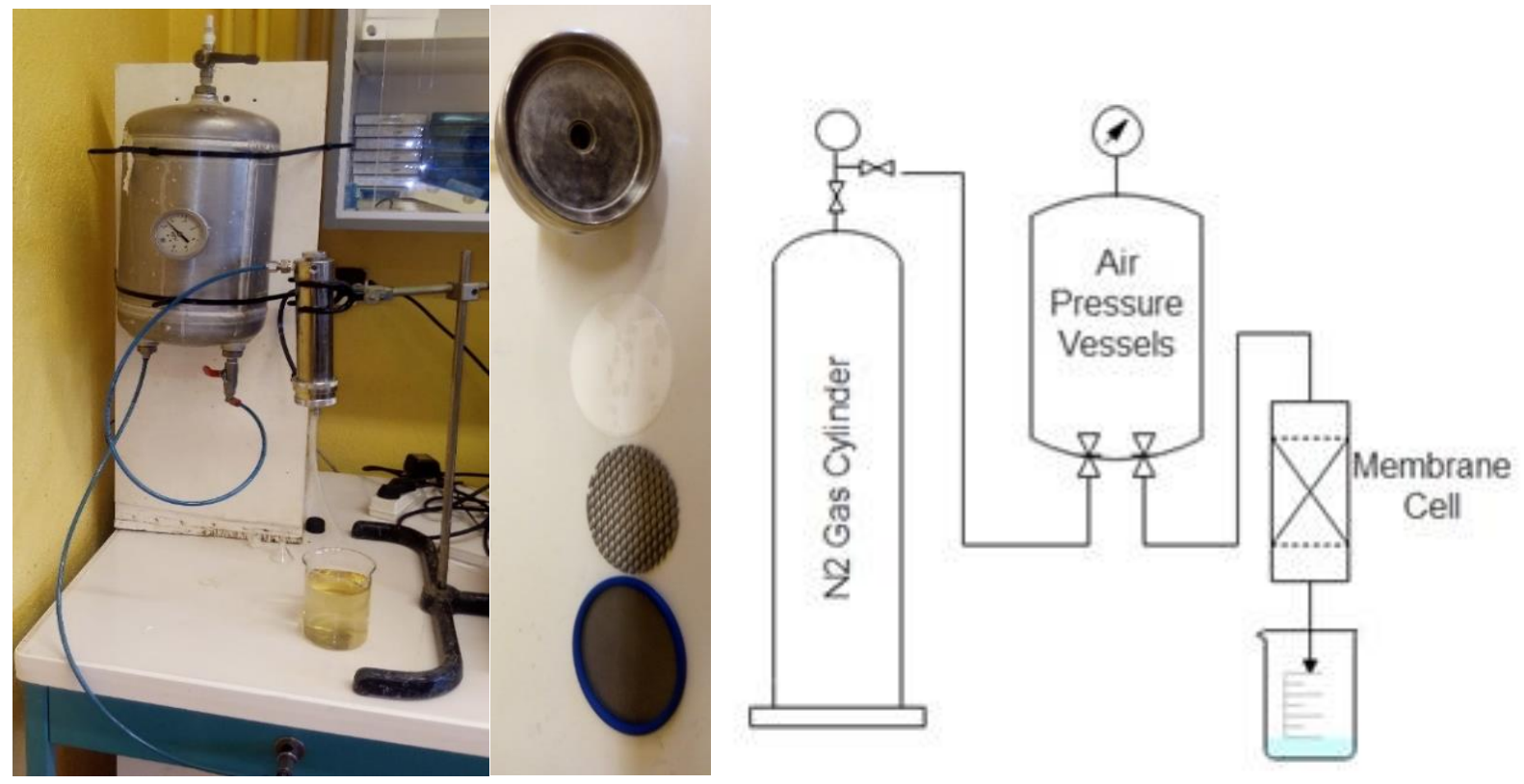

Figure 3-4 - Schematic image of the setup with a membrane cell used for pre-filtration experiments before dead-end filtration. 
- In the cross-flow UF

Before the PMTE samples were placed in the UF process they were treated in a conventional filtration (Figure 3-5) with a Cintropur® NW 50 filter element and centrifugal propeller and filter cloths with porosities of 50,25 and 5 microns $(\mu \mathrm{m})$ sequentially. The aim of this pre-treatment was to remove the large suspended solids in the PMTE in order to prevent early membrane pore blocking.

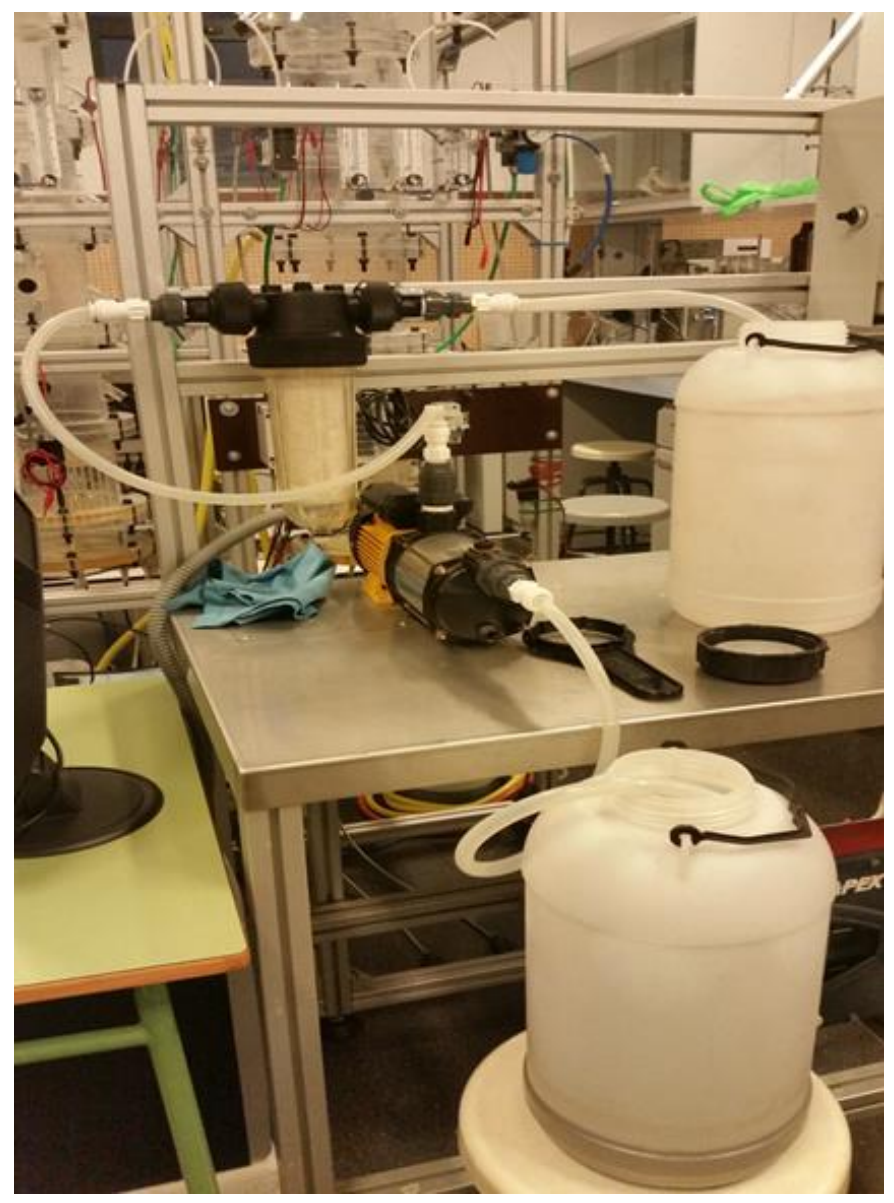

Figure 3-5 - Schematic image of the setup with a conventional filtration used for pretreatment before the cross-flow UF.

\subsection{Cross-flow filtration experiments}

\subsubsection{Cross-flow filtration setup}

Experimental tests were performed in a UF pilot plant, consisting of tanks for feeding and cleaning solutions with a capacity of 10 litres each. The conventionally pre-treated water from the feed tank was pumped to a flat-sheet membrane module (RhônePoulenc, France) that allowed working with two membranes with similar or different 
MWCO (depending on the experiment being carried out). The effective area for each membrane in the module was $154.8 \mathrm{~cm}^{2}$. These elements worked in parallel and were operated under cross-flow filtration using a 3CP-1221 piston pump. The required crossflow rates and transmembrane pressures were attained by controlling the input electromotor power and backpressure valve after the membrane module. A cooling/heating system was employed to achieve the required temperature.

In addition, the plant had data acquisition (temperature, module input and output pressure) through LabVIEW System Design Software. The real-time membrane flux was calculated from the difference between the two weight measures for each permeate, registered on two precision balances using MALTAB $^{\circledR}$ (Mathworks). The schematic diagram for the pilot plant process is shown in Figure 3-6 and Figure 3-7.

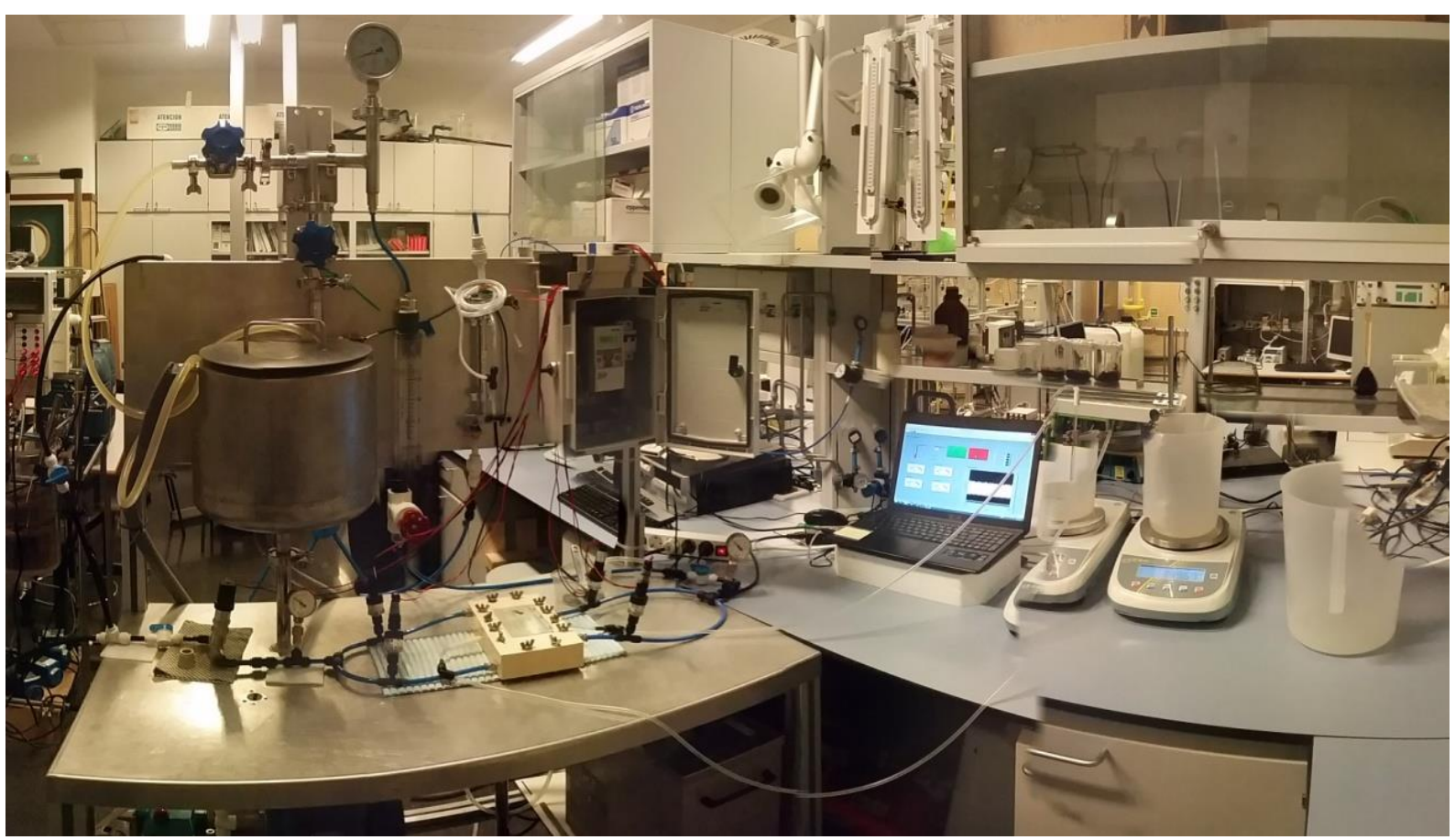

Figure 3-6 - Photographs of the experimental system. UF pilot plant with flat-sheet membrane module (Rhône-Poulenc, France). 


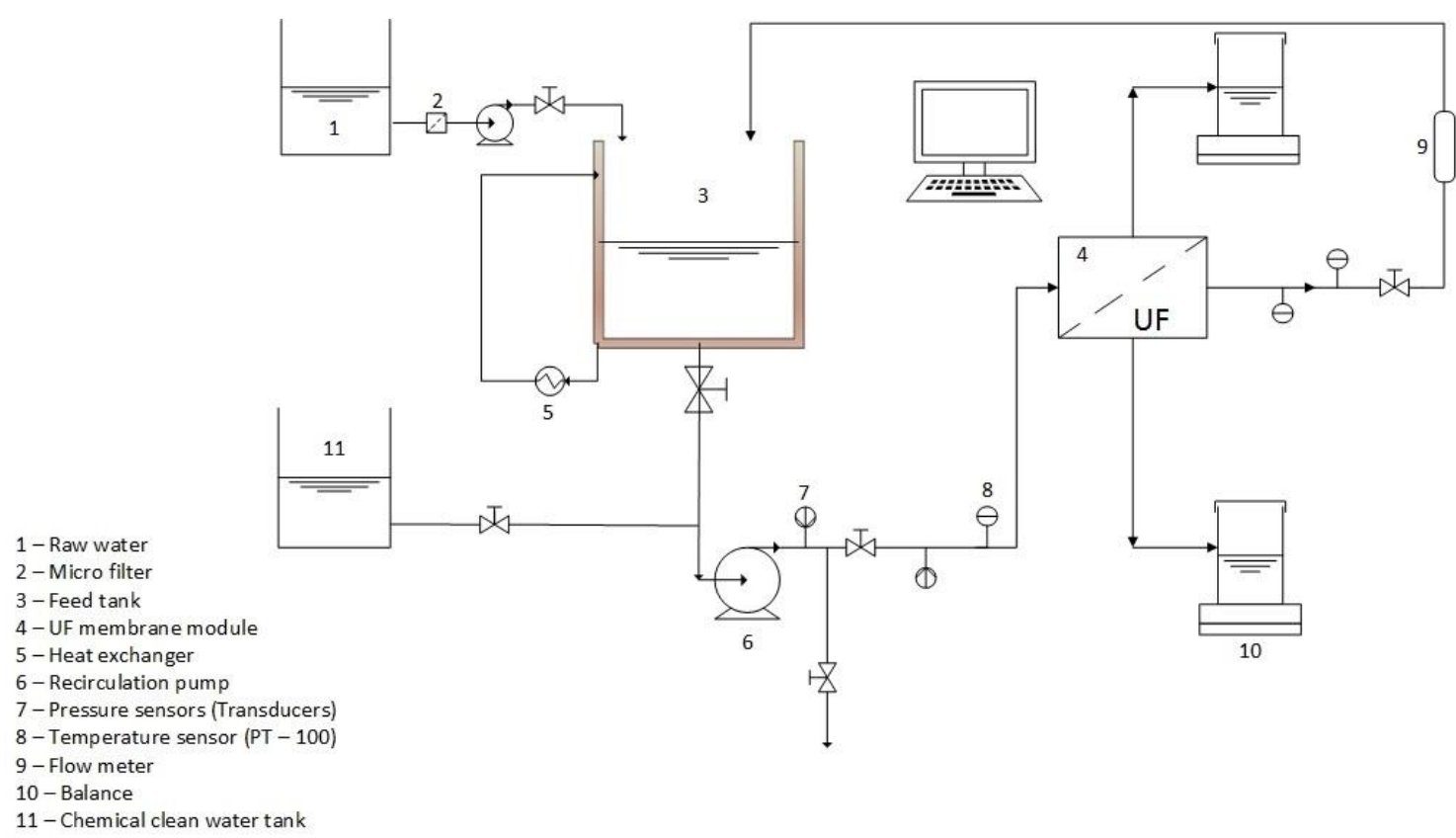

Figure 3-7 - Schematic diagram for the cross-flow ultrafiltration membrane process.

\subsubsection{Membrane characterisation}

Flux vs. TMP experiments withoutfouling were carried out to determine the intrinsic membrane resistance $\left(R_{m}\right)$. Distilled water was used as the feed solution and measurements were taken for different combinations of TMPs (1.0, 1.5, 2.0 and 3.0 bar) at $1.041 \mathrm{~m} / \mathrm{s}$ and $22.5^{\circ} \mathrm{C}$. The characterization process was undertaken for an operation time of 2 hours, it was necessary to stabilize the flux through the membrane during this time. Before the first use, each membrane was worked under compaction conditions with pure water at 5 bar for 1 hour, in order to obtain a stable membrane structure. $R_{m}$ values were calculated using the resistance model,Equation 3-2, where under this condition, there was no fouling on the membrane $\left(R_{f}=0\right)$ (Cheryan, 1998):

$$
J_{P}=\frac{T M P}{\mu R_{t}}=\frac{T M P}{\mu\left(R_{m}+R_{f}\right)}
$$

where:

$J_{P}$ is the permeate flux $(\mathrm{m} / \mathrm{s})$;

$T M P$ is the transmembrane pressure $(\mathrm{Pa})$;

$R_{m}$ is the intrinsic membrane resistance using pure water as the feed $\left(\mathrm{m}^{-1}\right)$;

$\mu$ is the viscosity of the permeate stream (Pa-s); 
$R_{f}$ is the membrane fouling resistance $\left(\mathrm{m}^{-1}\right)$ and;

$R_{f}$ can be understood as the result of the sum of the three main fouling mechanisms: pore blockage resistance $\left(R_{p b}\right)$ when colloids block the membrane pores, adsorption resistance $\left(R_{a}\right)$ as a result of foulant adsorption inside or over the membrane and cake layer resistance $\left(R_{c}\right)$ as a consequence of the accumulation of particles, DCS on the membrane (Khan et al., 2011; Mohammadi and Safavi, 2009; Rezaei et al., 2014).

\subsubsection{Flux decline in UF}

Once the membrane was characterised, the fouling tests were carried out under tangential flow UF. The aim of the tests was to determine the UF process efficiency under different operational parameters. The experiments were performed at different TMPs (1-3 bar) and crossflow rates (CFV) (1.5-4.5 L/min), MWCO (10 - $100 \mathrm{kDa})$ and temperature $\left(15-30^{\circ} \mathrm{C}\right)$. These parameters were selected based on the capability of the experimental setup (related to its operational limits), industrial scale-up and economic considerations (Sousa et al., 2018) . All the experiments were performed over 2 hours some experiments under 8 hours in total recirculation mode in order to generate a quasi-steady state.

Permeate flux was calculated from mass data and volume change data, where the permeate density was considered to be the water density at the operating temperature.

The evolution of permeate flux (volume of permeate obtained per unit time and membrane area) was gravimetrically measured from mass data and volume change data at different time intervals, where the permeate density was considered to be the water density at the operating temperature, as described by Darcy's Equation:

$$
J_{P}=\frac{1}{A_{m} \rho} \frac{d m_{p}}{d t}
$$

where,

A $m$ is the effective membrane area $\left(m^{2}\right)$;

$m_{p}$ is the total mass of permeate $(\mathrm{kg})$;

$\rho$ is the volumetric mass density $\left(\mathrm{kg} / \mathrm{m}^{3}\right)$; and

$\mathrm{t}$ is the filtration time (s). 
To keep the feed concentration constant both the permeate and the retained streams were continuously recirculated to the feed tank.

\subsubsection{Cleaning membranes procedure}

Membrane cleaning is necessary to restore the permeate flux through the membrane. It can be achieved by hydraulic, mechanical or chemical methods and techniques which depend on factors such as foulant characteristics, membrane material, and membrane configuration (Nguyen et al., 2010; Nguyen and Roddick, 2011).

The study of permeate flux recovery after membrane cleaning was carried out on a $10 \mathrm{kDa}$ PES membrane with an initial water permeate flux $(\mathrm{J} 0)$ of $68.6\left(\mathrm{~L} / \mathrm{m}^{2} / \mathrm{h}\right)$, which had been fouled by the recycled paper wastewater. The membrane cleaning procedure was undertaken using two methods (hydraulic cleaning and chemical cleaning) with the aim of evaluating the cleaning efficiency $\left(\mathrm{C}_{\mathrm{E}}\right)$.

Hydraulic cleaning was carried out in backwash. Deionised water was circulated for 20 minutes in cross-flow membrane system to flush out the impurities deposited in the membrane surface, at a temperature of $25^{\circ} \mathrm{C}$, flow rate $=4.5 \mathrm{l} / \mathrm{min}$ and transmembrane pressure of 4.5 bar.

The alkaline chemical cleaning was carried out using the following procedure:

- Rinsing with deionised water (10 min);

- Cleaning with aqueous $1.0 \mathrm{M} \mathrm{NaOH}$ solution, in deionised water (30 min) at pH 9.5;

- Rinsing with deionised water (10 min).

- Operating conditions: $\mathrm{T}=25^{\circ} \mathrm{C}, \mathrm{Pin}=4.5 \mathrm{bar}$ and flow rate $=4.5 \mathrm{l} / \mathrm{min}$ (for each cleaning step).

As described in the previous literature (Ahmad, 2013; Koo et al., 2016; Said et al., 2014) aqueous caustic solutions (i.e., $\mathrm{NaOH}$ ) are especially important for the removal of protein matter, colloidal and humic substances.

Further description of the cleaning protocols can be found in (Blanpain-Avet et al., 2009; Koo et al., 2016; Rabiller-Baudry et al., 2002).

Flux recovery and resistance removal were used to evaluate the cleaning efficiency of the procedure.The flux recovery (FR) and resistance removal (RR) by hydraulic and 
chemical cleaning were calculated using Equation 3-4 and Equation 3-5 (CorbatónBáguena et al., 2013; Koo et al., 2016; Srisukphun et al., 2015):

$$
F R(\%)=\frac{J_{p c}(t)-J_{p f}(t)}{J_{0}-J_{p f}(t)} \times 100 \%
$$

where,

$J_{p c}$ is permeate flux after cleaning;

$J_{p f}$ is permeate flux after fouling and;

$J_{0}$ is initial permeate flux before fouling.

$$
R R(\%)=\frac{R_{f}-R_{\text {irrev }}}{R_{f}} \times 100 \%
$$

Equation 3-5

where,

$R_{f}$ is the fouling resistance before cleaning as calculated from the permeate flux after each membrane fouling cycle $\left(U_{p, c y c l e}\right)$ and;

$R_{\text {irrev }}$ is the foulant resistance after cleaning as calculated from the permeate flux after cleaning membrane $\left({ }_{\text {recovery }}\right)$.

\subsection{Dead-end filtration experiments}

\subsubsection{Dead-end filtration setup}

Filtration experiments were carried out in a $400 \mathrm{~mL}$ stirring cell (Amicon 8400, Millipore, USA) connected to a pressurized tank $(800 \mathrm{~mL})$ and operated in dead-end filtration mode to filter large volumes of sample. The UF setup is shown in Figure 3-8. 


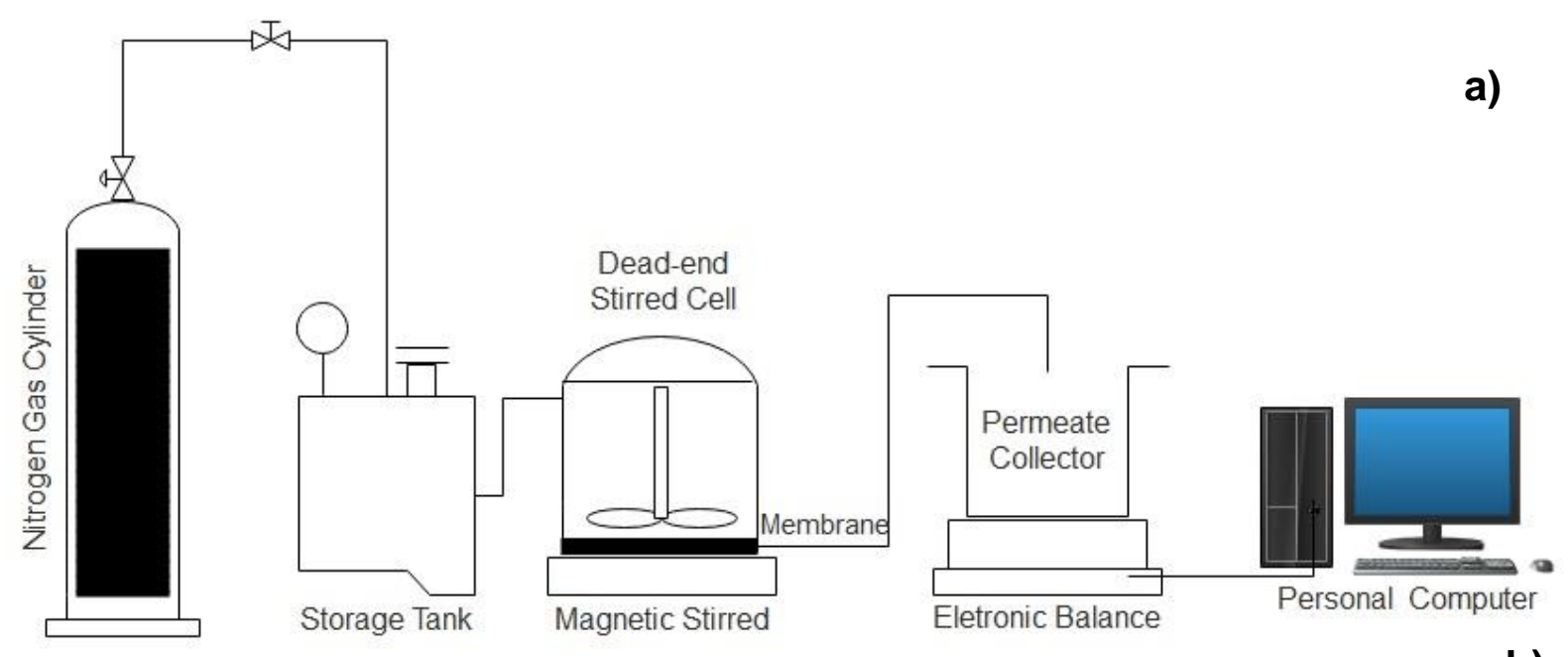

b)

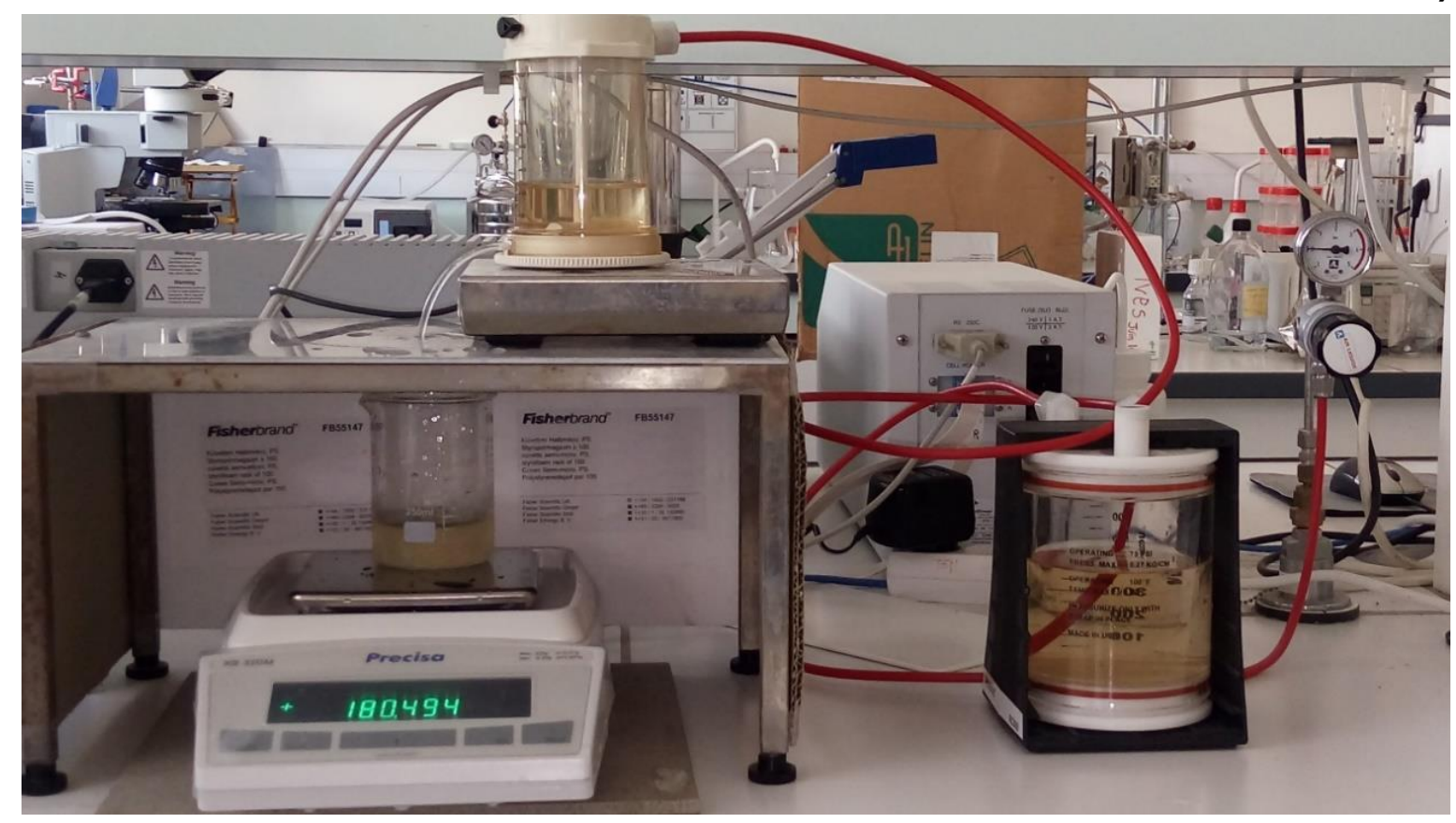

Figure 3-8 - Lab-scale of the dead-end membrane filtration system with stirred cell (a) process setup photograph and (b) pilot schematic diagram.

The membranes were placed at the bottom of the cell with active layer side in toward the feed solution. Nitrogen gas was used to drive the feed solution through the membranes at constant pressure. The permeate was collected into beaker placed on an electronic balance in order to continuously monitor the weight change throughout the process. This was carried out through a data acquisition system and the data were automatically logged each fifteen seconds. 


\subsubsection{Filtration experiments}

Prior to the UF experiments, the new membranes were soaked in Milli-Q water for 24 $\mathrm{h}$ and then carefully rinsed. For the membrane characterization measurements, distilled water was used as the feed solution for each membrane and the water flux was given the term $\left(J_{w}\right)$. Filtration were performed under different transmembrane pressures (TMPs) $(0.5,1.0,1.5$ and 2.0 bar) at room temperature.

After determining the clean water flux, the fouling experiments were performed on membranes with differentMWCO $(10 \mathrm{kDa}, 50 \mathrm{kDa}$ and $100 \mathrm{kDa})$ in order to understand the role this parameter plays in fouling propensities. Every UF experiment included filtration of $250 \mathrm{ml}$ of the pre-filtered PMTE as a feed sample ( see section 6.3.1). The filtration protocol also included membrane washing steps in accordance with the methodology described by C. Jacquin et al. (2018) .

\subsection{References}

Ahmad, A., 2013. Optimization of $\mathrm{NaOH}$ as the cleaning of Polyethersulfone (PES) membrane fouled by Palm oil mill effluent. https://doi.org/10.13140/2.1.2352.7369 APHA, 1998. Standard Methods for the Examination of Water and Wastewater, 20th Edition. American Public Health Association, Washington DC.

Archer, A.D., Singer, P.C., 2006. An evaluation of the relationship between SUVA and NOM coagulation using the ICR database. Journal - American Water Works Association 98, 110-123. https://doi.org/10.1002/j.1551-8833.2006.tb07715.x

Blanpain-Avet, P., Migdal, J.F., Bénézech, T., 2009. Chemical cleaning of a tubular ceramic microfiltration membrane fouled with a whey protein concentrate suspension-Characterization of hydraulic and chemical cleanliness. Journal of Membrane Science 337, 153-174. https://doi.org/10.1016/j.memsci.2009.03.033

C. Jacquin, C., Teychene, B., Lemee, L., Lesage, G., Heran, M., 2018. Characteristics and fouling behaviors of Dissolved Organic Matter fractions in a full-scale submerged membrane bioreactor for municipal wastewater treatment. Biochemical Engineering Journal 132, 169-181. https://doi.org/10.1016/j.bej.2017.12.016

Cheryan, M., 1998. Ultrafiltration and Microfiltration Handbook. CRC Press. 
Corbatón-Báguena, M.-J., Vincent-Vela, M.-C., Álvarez-Blanco, S., Lora-García, J., 2013. Analysis of Two Ultrafiltration Fouling Models and Estimation of Model Parameters as a Function of Operational Conditions. Transp Porous Med 99, $391-$ 411. https://doi.org/10.1007/s11242-013-0192-4

Edzwald, J.K., Tobiason, J.E., 1999. Enhanced coagulation: US requirements and a broader view. Water Science and Technology 40, 63-70. https://doi.org/10.1016/S0273-1223(99)00641-1

Howe, K.J., Marwah, A., Chiu, K.-P., Adham, S.S., 2006. Effect of coagulation on the size of MF and UF membrane foulants. Environ. Sci. Technol. 40, 7908-7913.

Khan, M.Md.T., Takizawa, S., Lewandowski, Z., Jones, W.L., Camper, A.K., Katayama, H., Kurisu, F., Ohgaki, S., 2011. Membrane fouling due to dynamic particle size changes in the aerated hybrid PAC-MF system. Journal of Membrane Science 371, 99-107. https://doi.org/10.1016/j.memsci.2011.01.017

Koo, C.C.H., Wong, K.H., Chong, W.C., Thiam, H.S., 2016. CHEMICAL CLEANING OF NANOFILTRATION MEMBRANES FOULED BY ORGANIC MATTERS 11, 14.

Korshin, G.V., Li, C.-W., Benjamin, M.M., 1997. The decrease of UV absorbance as an indicator of TOX formation. Water Research 31, 946-949. https://doi.org/10.1016/S0043-1354(96)00393-4

Liu, Y., Bo, S., Zhu, Y., Zhang, W., 2003. Determination of molecular weight and molecular sizes of polymers by high temperature gel permeation chromatography with a static and dynamic laser light scattering detector. Polymer 44, 7209-7220. https://doi.org/10.1016/j.polymer.2003.08.037

Mohammadi, T., Safavi, M.A., 2009. Application of Taguchi method in optimization of desalination by vacuum membrane distillation. Desalination 249, 83-89. https://doi.org/10.1016/j.desal.2009.01.017

Nguyen, S.T., Roddick, F.A., 2011. Chemical cleaning of ultrafiltration membrane fouled by an activated sludge effluent. Desalination and Water Treatment 34, 94-99. https://doi.org/10.5004/dwt.2011.2790 
Nguyen, S.T., Roddick, F.A., Harris, J.L., 2010. Membrane foulants and fouling mechanisms in microfiltration and ultrafiltration of an activated sludge effluent. Water Sci. Technol. 62, 1975-1983. https://doi.org/10.2166/wst.2010.505

Potter, B.B., Wimsatt, J.C., 2009. Determination of total organic carbon and specific UV absorbance at $254 \mathrm{~nm}$ in source water and drinking water 56.

Rabiller-Baudry, M., Le Maux, M., Chaufer, B., Begoin, L., 2002. Characterisation of cleaned and fouled membrane by ATR-FTIR and EDX analysis coupled with SEM: application to UF of skimmed milk with a PES membrane. Desalination 146, 123-128. https://doi.org/10.1016/S0011-9164(02)00503-9

Rezaei, H., Ashtiani, F.Z., Fouladitajar, A., 2014. Fouling behavior and performance of microfiltration membranes for whey treatment in steady and unsteady-state conditions. Brazilian Journal of Chemical Engineering 31, 503-518. https://doi.org/10.1590/0104-6632.20140312s00002521

Said, M., Mohammad, A., Nor, M., Abdullah, S., Abu Hasan, H., 2014. Chemical cleaning of fouled polyethersulphone membranes during ultrafiltration of palm oil mill effluent. Membrane Water Treatment 5, 207-219. https://doi.org/10.12989/mwt.2014.5.3.207

Sousa, M.R.S., Lora-Garcia, J., López-Pérez, M.-F., 2018. Modelling approach to an ultrafiltration process for the removal of dissolved and colloidal substances from treated wastewater for reuse in recycled paper manufacturing. Journal of Water Process Engineering 21, 96-106. https://doi.org/10.1016/j.jwpe.2017.11.017

Srisukphun, T., Chiemchaisri, C., Chiemchaisri, W., Thanuttamavong, M., Srisukphun, T., Chiemchaisri, C., Chiemchaisri, W., Thanuttamavong, M., 2015. Fouling and cleaning of reverse osmosis membrane applied to membrane bioreactor effluent treating textile wastewater. Environmental Engineering Research 21, 45-51. https://doi.org/10.4491/eer.2015.090

Yoon, S.-H., 2015. Membrane Bioreactor Processes: Principles and Applications. 


\section{CHAPTER: PROCESS OPTIMIZATION VIA TAGUCHI METHOD TO REMOVE COLLOIDAL SUBSTANCES FROM RECYCLED PAPER AND CARDBOARD PRODUCTION WASTEWATER}




\subsection{Abstract}

Optimization of the ultrafiltration (UF) process to remove colloidal substances from a paper mill's treated effluent was investigated in this study. The effects of four operating parameters in a UF system (transmembrane pressure (TMP), cross-flow velocity (CFV), temperature and molecular weightcut-off (MWCO)) on the average permeate flux $\left(\overline{J_{P}}\right)$, organic matter chemical oxygen demand (COD) rejection rate and the cumulative flux decline (SFD), was investigated by robust experimental design using Taguchi method.

Analysis of variance (ANOVA) for an L9 orthogonal array were used to determine the significance of the individual factors, that is to say, to determine which factor has more and which less influence over the UF response variables. Analysis of the percentage contribution (P\%) indicated that the TMP and MWCO have the greatest contribution to the average permeate flux and SFD. In the case of the COD rejection rate, the results showed that MWCO has the highest contribution followed by CFV.

The Taguchi method and the utility concept were employed to optimize the multiple response variables. The optimum conditions were found to be 2.0 bar of transmembrane pressure, $1.041 \mathrm{~m} / \mathrm{s}$ of the cross-flow velocity, $15{ }^{\circ} \mathrm{C}$ of the temperature, and $100 \mathrm{kDa}$ MWCO. The validation experiments under the optimum conditions achieved $\overline{J_{P}}$, COD rejection rate and SFD results of $81.15 \mathrm{~L} / \mathrm{m}^{2} / \mathrm{h}, 43.90 \%$ and 6.01, respectively. Additionally, SST and turbidity decreased by about $99 \%$ and $99.5 \%$, respectively, and reduction in particle size from around $458-1281 \mathrm{~nm}$ to 12.71

- $24.36 \mathrm{~nm}$ was achieved. The field emission scanning electron microscopy images under optimum conditions showed that membrane fouling takes place at the highest rate in the first 30 minutes of UF. The results demonstrate the validity of the approach of using Taguchi method and utility concept to obtain the optimal membrane conditions for the wastewater treatment using a reduced number of experiment. 


\subsection{Introduction}

Ultrafiltration is an attractive process for paper mill wastewater treatment and it can be used as an advanced tertiary treatment to remove suspended solids and dissolved and colloidal substances (DCS) during the treatment of paper industry effluent in order to facilitate the reuse of the treated wastewater and reduce fresh water consumption (Chen et al., 2015b; Krawczyk et al., 2013). What makes it so attractive is that most of the pollutants consist of high-molecular-weight compounds and these are easily removed by UF (Gönder et al., 2012; Sousa et al., 2018).

However, membrane fouling is still a limiting factor for the adoption and use of UF on a large scale in paper manufacturing applications. This fouling results in a shap decline in permeate flux and, thus, changes in membranes selectivity (Gönder et al., 2012; Kamali and Khodaparast, 2015b; Mänttäri et al., 1997). Membrane fouling also increases the process cost due to repeated plant shutdowns to clean and wash the membranes (Cassano et al., 2011). Previous studies have shown that the main foulants on the membranes used for paper industry wastewater are DCS including fatty acids, resin acids, lignins and trace amounts of sterols, steryl esters and triglycerides (Chen et al., 2015b; Puro et al., 2002b). Currently, this treatment technology can only be used to filter paperboard mill treated effluent that has been pre-treated and that already meets discharge standards (Puro et al., 2011b).

Membrane and operating conditions selection are important in minimizing membrane fouling. Statistical experimental design incorporating design of experiments (DOE) techniques can be used to investigate the effects of all the possible interactions between the factors at one time, while undertaking the fewest possible experiments. A review of the literature revealed that an increasing number of studies are being conducted using DOE approaches in the membrane technology field to optimize operating conditions (Gönderet al., 2012; Hesampouret al., 2008; Khaire and Gogate, 2020; Pourjafar et al., 2013; Reyhani et al., 2015, 2015; Rezvan pour et al., 2009; Salahi et al., 2010; Zoubeik et al., 2020). The DOE approaches for robust design include the Taguchi method which combines mathematical and statistical techniques to arrive at a special design of experiments with an orthogonal array (OA) to study multiple factors with a small number of experiments. This saves time and money by reducing the number of experiments required in the investigation (Beril Gönder et al., 
2011). It is worth mentioning that this approach is becoming popularbecause it is easy to adopt and applies an efficient method for optimizing the operating parameters.

This approach also allows to study the influence of each individual factors on the response variables, as well as on the effects of interactions between factors over response variables, it is to say all operational conditions varying simultaneously according design array. This permits the factors that have the greatest and least influence to be determined, along with the optimum level for each factor in an OA (Ezzati et al., 2005). In addition, in many UF approaches, is necessary to consider the application of multiple response optimization, because the process performance is often evaluated using several quality characteristics (responses). In this case, the Taguchi method and utility concept are useful tools for optimizing operating parameters in multiple characteristics responses (Kaladhar et al., 2011).

A statistical analysis of variance (ANOVA) can be used to provide information on whether the operating parameters (factors) are statistically significant or not, as well as to identify the influence of individual factors and establish the relationships between the factors and operating conditions. The F-test and P-value in ANOVA analyses are powerful tools for deciding which operating parameters have a more or less significant effect on the response variables (obtaining a maximum or minimum) (Mohammadi and Safavi, 2009; Park, 1996). In this study, ANOVA was also used to analyze the experimental results.

The aim of this work was to determinate the effect of operating conditions such as transmembrane pressure (TMP), cross-flow velocity (CFV), temperature and molecular weight cut-off (MWCO) on the average permeate flux, COD rejection rate and cumulative flux decline (SFD), in addition to determining the optimum conditions for the given sets of values and to find the best response variables by using Taguchi experimental design and the utility concept. The results of this study may be used as a guideline when operating UF systems under the best conditions in a wastewater treatment plant (WWTP) in a papermaking factory. The filtration results and analysis of the experimental data presented and discussed in this study were carried out by using ANOVA to find the significance of the controlling factors and optimized using the Taguchi method to find the optimum operating conditions. A standard L 9 orthogonal array was selected for experimental planning with fourfactors and three levels for each factor. 


\subsection{Materials and methods}

\subsubsection{Paper mill treated effluent feedstock}

The paper mill treated effluent (PMTE) used in this work was obtained came from a secondary clarifier effluent from a wastewater treatment plant (WWTP) in a papermaking factory located in the south of the Valencian autonomous region in Spain. In order to prevent early membrane fouling, remove large suspended solids, and reduce initial turbidity and COD in the PMTE, the raw feed solution was pre-filtered by conventional filtration (low-pressure pump at around 1 bar) with a Cintropur ${ }^{\circledR}$ NW 50 filter element, and centrifugal propeller and filter cloths with a $5 \mu \mathrm{m}$ nominal pore size. The significant characteristics of the PMTE samples are listed in Table 4-1.

Table 4-1 - Average compositions of the paperboard mill treated effluent (biologically treated wastewater) used in the experiments.

\begin{tabular}{ccc}
\hline \hline Parameter & units & value \\
\hline \hline Suspended solids (TSS) & $\mathrm{g} \cdot \mathrm{L}^{-1}$ & $0.046 \pm 0.01$ \\
Turbidity & $\mathrm{NTU}$ & $3.21 \pm 0.5$ \\
Conductivity & $\mathrm{ms} . \mathrm{cm}^{-1}$ & $4.20 \pm 1.0$ \\
COD & $\mathrm{mg} \cdot \mathrm{L}^{-1}$ & $146 \pm 5.0$ \\
Total nitrogen & $\mathrm{mg} \cdot \mathrm{L}^{-1}$ & $0.8 \pm 0.01$ \\
$\mathrm{pH}$ & - & $8.30 \pm 0.5$ \\
\hline \hline
\end{tabular}

* Pre-filtered by conventional filtration (Pre-treatment).

\subsubsection{Membranes and experimental setup}

This study used polyethersulfone (PES) membranes provided by Synder Filtration ${ }^{\mathrm{TM}}$ (Vacaville, USA) with a molecular weight cut-off (MWCO) of 10,50 and $100 \mathrm{kDa}$, denoted 10-ST, 50-MQ and 100-LY, respectively.

The experiments were performed in a typical UF pilot plant with a flat-sheet membrane module (Rhône-Poulenc, France), that allowed working with two membranes with similar or different MWCO (depending on the experiment being carried out). The effective area for each membrane in the module was $154.8 \mathrm{~cm}^{2}$. The details of the experimental set-up have been described previously by Sousa et al. (2018) section 3.5.

The pilot plant had a data acquisition system (temperature, module input and output pressure) from LabVIEW ${ }^{\circledR}$. The permeate was collected during the filtration in a beaker 
placed on an electronic balance connected to a computer in order to continuously register the weighting data. This data was then automatically logged every thirty seconds and subsequently used to calculate permeate flux through the membranes.

\subsubsection{Analytical methods}

The PMTE used as the feed solution and the UF permeate samples were analyzed according to the methods described below. The suspended solids analyses were carried out in accordance with the Standard Methods (APHA, 1998). Turbidity was measured using a Dinko 112 turbidimeter (ASTM D1889). Conductivity was measured using a WTW level 3 conductivity device (ASTM D1125-14). COD and total nitrogen in the effluent was analyzed using a Merck photometer and a Merck TR-300 thermoreactor in accordance with the Standard Methods (APHA, 1998).

\subsubsection{Field emission scanning electron microscopy (FESEM)}

FESEM measurements were used to provide information on the fouling that formed on the membranes. The surface and cross-section morphologies of the fresh and fouled membranes were observed by field emission scanning electron microscope, (ZEISS ULTRA 55, Oxford Instruments, UK), operated with a voltage of $200 \mathrm{kV}$ and an accelerating voltage of $0.02-5 \mathrm{kV}$. Before analysis, the dried membrane samples were attached to double-sided adhesive carbon tape on an aluminum holder, and subsequently coated with a thin layer of gold prior to analysis.

\subsubsection{Experimental procedure}

\subsubsection{Ultrafiltration experiments}

Previous to the UF runs, permeability experiments were carried out to determine the intrinsic membrane resistance $(R m)$. Distilled water was used as the feed solution and measurements were taken for 1.0, 1.5, 2.0 and 3.0 bar of transmembrane pressure $(T M P)$ at $1.041 \mathrm{~m} / \mathrm{s}$ and $22.5^{\circ} \mathrm{C}$, in total recirculation mode to generate a quasi-steady state. The characterization process was undertaken for an operation time of 2 hours to stabilize the flux through the membrane during this time.

The UF experiments were performed in crossflow filtration mode. The studied parameters were varied in the following ranges: TMP (1.0-3.0 bar), CFV (0.463 $1.041 \mathrm{~m} / \mathrm{s})$, MWCO $(10-100 \mathrm{kDa})$ and temperature $\left(15-30^{\circ} \mathrm{C}\right)$. These values were selected based on the operational limits of the experimental setup, industrial scale-up 
and economic considerations (Sousa et al., 2018). The evolution of permeate flux was gravimetrically measured at different time intervals and described by Darcy's law Equation 3-3.

In section 4.3.6 (Experimental design based on the Taguchi method) summarizes the operating conditions tested.

4.3.5.2 Average permeate flux, COD rejection and cumulative flux decline analysis

To evaluate the UF performance in terms of permeability the first response parameter considered was the average permeate flux calculated by integrating $J_{P}(t)\left(t_{1}>0\right.$ up to $t_{M}=120 \mathrm{~min}$ ), which can be described by the following equation (Cojocaru and Zakrzewska-Trznadel, 2007):

$$
\bar{J}_{P}=\frac{1}{t_{M}} \cdot \int_{t_{1}}^{t_{M}} J_{P}(t) \cdot d t
$$

Equation 4-1

where:

$J_{P}(t)$ is the permeate flux evolution over time, determined by regression analysis on the experimental data;

$t_{1}$ is the initial time operation (first time interval after $t_{0}$ ); and

$t_{M}$ is the time corresponding to the last value of the permeate flux considered (when a quasi-stationary was reached).

To analyze the effect of the operating conditions on UF resistance, the second response chosen was the cumulative flux decline (SFD), defined in previous studies by Cojocaru and Zakrzewska-Trznadel, (2007), which is calculated from the following relationship:

$$
S F D=\sum_{i=1}^{M} \frac{J_{P}(0)-J_{P}(i)}{J_{P}(0)}
$$

Equation 4-2

where:

$M$ is the number of experimental points required to achieve the quasi-stationary permeate flux, in this study $M=21$ (corresponding to the end of the experiment); $J_{P}(0)$ is the initial permeate flux measured at the initial time operation $t_{1}$; and $J_{P}(i)$ is the permeate flux measured subsequently $J_{P}(i)>J_{P}(0)$. 
This parameter give information about how the flux declines over the duration of the experiment (not just the difference between the initial and final permeate flux), that is to say, it gives the intensity of membrane fouling from the start to the finish. Therefore, the higher the SFD value, the faster and more noticeable is the flux decline, indicating that the membrane fouling is more severe. In addition, the average flux decline index $(\overline{F D})$ provides information on the decrease of feed permeate flux throughout time experiment and can be estimated as follows:

$$
\overline{F D}=\left[\frac{1}{t_{M}} \cdot \int_{t_{1}}^{t_{M}} \frac{J_{P}(0)-J_{P}(t)}{J_{P}(0)} \cdot d t\right] \times 100
$$

Equation 4-3

To evaluate the UF efficiency in removing organic matter, the COD rejection rate was chosen as the third response parameter, calculated as:

$$
R(\%)=1-\frac{C_{p}}{C_{f}} * 100
$$

Equation 4-4

where: $C_{p}$ and $C_{f}$ are the COD concentration $(\mathrm{mg} / \mathrm{L})$ in the permeate and feed, respectively.

\subsubsection{Experimental design based on the Taguchi method}

An experimental design based on the Taguchi method was used to design the experiments. The Taguchi method applies fractional experimental designs, called orthogonal arrays $(\mathrm{OA})$, to reduce the number of experiments required to determine the optimum conditions based on the results (Alsaadi and Sheeraz, 2020; Idris et al., 2002; Reyhani et al., 2015; Rezvanpour et al., 2009). One of the important steps in the Taguchi approach is the appropriate selection of OA, which depends on the number of control factors and their levels. The minimum number of experimental trails required in an $O A$ is given by $N_{\min }=(L-1) F+1$, where $F$ and $N$ are the number of factors and levels respectively (Park, 1996; Phadke, 1989).

As mentioned above, the four factors (parameters) chosen were the transmembrane pressure, the cross-flow velocity, the temperature and the molecular weight cut-off of the membrane; and three response variables were analyzed: the average permeate flux, the COD rejection and the cumulative flux decline. The selected factors, their designated symbols and levels are presented in Table 4-2. 
Table 4-2 - Process parameters and their levels.

\begin{tabular}{ccccc}
\hline \hline \multirow{2}{*}{ Parameters } & \multirow{2}{*}{ Labels } & \multicolumn{3}{c}{ Levels } \\
\cline { 3 - 5 } & & $\mathrm{L} 1$ & $\mathrm{~L} 2$ & $\mathrm{~L} 3$ \\
\hline \hline TMP $($ bar $)$ & $\mathrm{A}$ & 1.0 & 2.0 & 3.0 \\
CFV $(\mathrm{m} / \mathrm{s})$ & $\mathrm{B}$ & 0.463 & 0.752 & 1.041 \\
Temperature $\left({ }^{\circ} \mathrm{C}\right)$ & $\mathrm{C}$ & 15.0 & 22.5 & 30.0 \\
MWCO $(\mathrm{kDa})$ & $\mathrm{D}$ & 10 & 50 & 100 \\
\hline \hline
\end{tabular}

* MWCO=Molecular weight cut-off.

According to the Taguchi method, an experimental design should be selected for the controllable factors and their levels as this helps to determine the lowest number of experiments possible. For an experimental design with four factors and three levels for each factor, an L9 $\left(3^{4}\right)$ orthogonal array was selected. In this case, 27 runs were conducted (three repetitions at each trial condition). With the traditional factorial methodology (full factorial experimentation $\left.3^{4}\right), 243(=3 \times 81)$ experiments would have been required. Thus, the number of experiments required was drastically reduced. The design of the experiments planning matrix for the L9 array (Phadke,1989) is shown in Table 4-3.

Table 4-3 - Experimental layout using L9 (34) orthogonal array in accordance with the Taguchi method.

\begin{tabular}{ccccc}
\hline \hline \multirow{2}{*}{ Experimental trial $\mathrm{n}^{\circ}}$. & \multicolumn{5}{c}{ Levels } \\
\cline { 2 - 5 } & $\mathrm{A}$ & $\mathrm{B}$ & $\mathrm{C}$ & $\mathrm{D}$ \\
\hline \hline 1 & 1 & 1 & 1 & 1 \\
2 & 1 & 2 & 2 & 2 \\
3 & 1 & 3 & 3 & 3 \\
4 & 2 & 1 & 2 & 3 \\
5 & 2 & 2 & 3 & 1 \\
6 & 2 & 3 & 1 & 2 \\
7 & 3 & 1 & 3 & 2 \\
8 & 3 & 2 & 1 & 3 \\
9 & 3 & 3 & 2 & 1 \\
\hline \hline
\end{tabular}

* All experiments were carried out in a randomized run.

The aim of this DOE was to determine the operating parameters (factors) under which the average permeate flux and COD rejection rate achieve their maximum values, and 
the SFD achieved its minimum value. The Taguchi method uses a statistical measure of the process performance, called signal-to-noise $(\mathrm{S} / \mathrm{N})$, which depends on the criterion for the response variable to be optimized. The $S / N$ ratios are divided into three different categories and data sets, the larger-the better, the smaller-the-better and the nominal-the-better (Beril Gönder et al., 2011; Reyhani et al., 2015). In this study, the system was optimized when the average permeate flux and COD rejection rate were as large as possible Equation 4-5), and the SFD was as small as possible Equation 4-6):

$$
\begin{array}{ll}
\text { The larger }- \text { the }- \text { better }(\mathrm{S} / \mathrm{N})=-10 \log \left(\frac{1}{\mathrm{n}} \sum_{\mathrm{i}=1}^{\mathrm{n}} \frac{1}{\mathrm{Y}_{\mathrm{i}}^{2}}\right) & \text { Equation 4-5 } \\
\text { The smaller }- \text { the }- \text { better }(\mathrm{S} / \mathrm{N})=-10 \log \left(\frac{1}{\mathrm{n}} \sum_{\mathrm{i}=1}^{\mathrm{n}} \mathrm{Y}_{\mathrm{i}}^{2}\right) & \text { Equation 4-6 }
\end{array}
$$

where:

$(\mathrm{S} / \mathrm{N})$ is the signal-to-noise ratio $(\mathrm{dB})$;

$n$ represents the total number of repetitions in a trial; and

$Y_{i}$ is the response parameter at each experiment.

The sequence of steps to be followed using the Taguchi method to optimize the UF process is shown in Figure 4-1. 


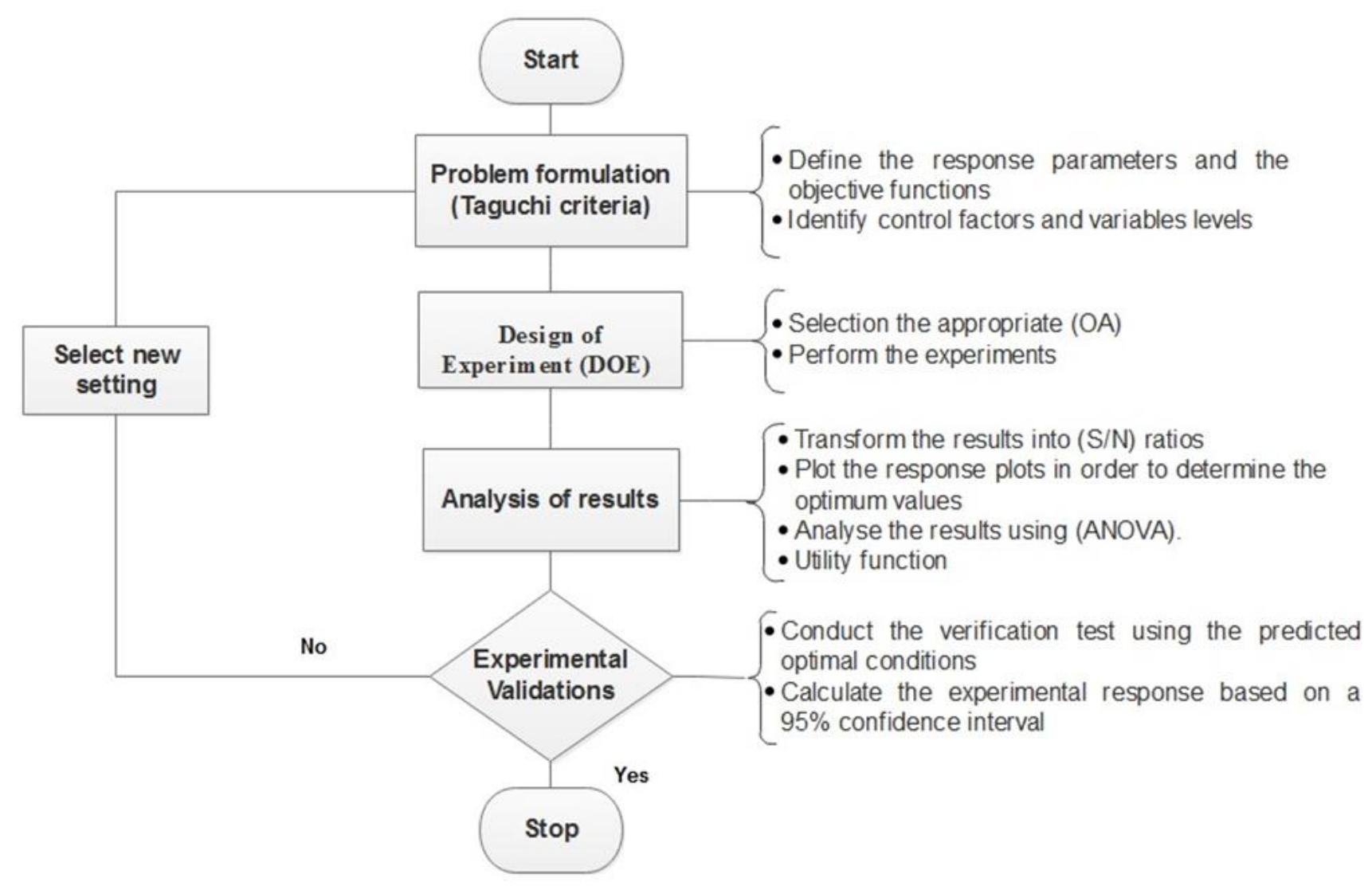

Figure 4-1 Flow diagram of Taguchi method steps to optimize a UF process to remove DCS from paperboard mill treated effluent (Kumar and Singh, 2014; Roy, 1990).

Minitab Statistical and Statgraphics Centurion XVII Software were used to analyse the Taguchi experiments and optimize the operating conditions.

\subsubsection{Utility concept}

The implementation of the utility concept in the Taguchi method helps to obtain the best combination of operating parameters to optimize multiple response $\mathrm{S} / \mathrm{N}$ ratios (MRSN) simultaneously by differentiating the relative importance (weights) of various responses (Barua et al., 1997; Goyal et al., 2016; Kaladhar et al., 2011). In this work, it is assumed that the overall utility is the sum of each individual utility's response and it can be written as (Bunn, 1982; Kaladhar et al., 2011):

$$
\mathrm{U}\left(\mathrm{x}_{1}, \mathrm{x}_{2}, \ldots \mathrm{x}_{\mathrm{n}}\right)=\mathrm{f}\left[\mathrm{U}_{1}\left(\mathrm{x}_{1}\right), \mathrm{U}_{2}\left(\mathrm{x}_{2}\right), \ldots \mathrm{U}_{\mathrm{n}}\left(\mathrm{x}_{\mathrm{n}}\right)\right] \quad \text { Equation 4-7 }
$$

where;

$\mathrm{U}\left(\mathrm{x}_{1}, \mathrm{x}_{2}, \ldots \mathrm{x}_{\mathrm{n}}\right)$ is the overall utility of $n$ response parameters; and

$\mathrm{U}_{\mathrm{i}}\left(\mathrm{x}_{\mathrm{i}}\right)$ is utility index of $i^{\text {th }}$ response. 
The response variables can be attributed priorities depending upon the process goals to be achieved. The priorities can be adjusted by providing a weight to the individual utility index. Therefore, by assigning weights to the response variables, the overall utility function can be expressed as:

$$
\mathrm{U}\left(\mathrm{x}_{1}, \mathrm{x}_{2}, \ldots \mathrm{x}_{\mathrm{n}}\right)=\sum_{\mathrm{i}=1}^{\mathrm{n}} \mathrm{W}_{\mathrm{i}} \mathrm{U}_{\mathrm{i}}\left(\mathrm{x}_{\mathrm{i}}\right)
$$

where,

$\mathrm{W}_{\mathrm{i}}$ is the weight assigned to the $i^{\text {th }}$ response characteristic.

It is worth noting that the assignment of weights is a purely subjective (empirical) step and depends on each experiment or process that will be carried out (Kumar and Singh, 2014). Therefore, in this paper, the Analytic Hierarchy Process (AHP) method, developed by Saaty, (1980) was used to determine the associate weight criteria for each response variable in the multiple optimization required to calculate the overall utility index. The relative normalized weight $W_{i}$ of each criterion is calculated using the AHP geometric mean method $G M_{i}$ on the rows in the pairwise comparison matrix, A $\|a i j\|$ and it can be calculated from the follow equation (Saaty, 1980):

$$
W_{i}=\frac{G M_{i}}{\sum_{i=1}^{M} G M_{i}}
$$

where:

$i, j=1,2, \ldots, M$ and $M$ is the number of factors in judgement matrix $\mathrm{A}$.

$a_{i j}=1$ for $i=j$,

$a_{i j}=\frac{1}{a_{i j}}$ for $i \neq j$.

In addition, the total sum of the weight for all the responses must be assigned to hold the following condition:

$$
\sum_{i=1}^{n} w_{i}=1
$$

For this optimization, as stated above, the objective was to maximize permeate flux and COD rejection rate, and minimize the SFD, simultaneously. From the utility concept, the MRSN of the overall utility value is given by Equation 4-11. 


$$
\mu_{\mathrm{MRSN}}=\mathrm{W}_{\overline{\mathrm{J}}_{\mathrm{P}}} \mu_{1}+\mathrm{W}_{\mathrm{COD} \text { Rejection }} \mu_{2}+\mathrm{W}_{\mathrm{SFD}} \mu_{3} \quad \text { Equation 4-11 }
$$

Where:

$$
\begin{gathered}
\mu_{1}=-10 \log \left(\frac{1}{\bar{J}_{\mathrm{P}}{ }^{2}}\right) \\
\mu_{2}=-10 \log \left(\frac{1}{\mathrm{COD}_{\text {rejection }}{ }^{2}}\right) \\
\mu_{3}=-10 \log \left(\mathrm{SFD}^{2}\right)
\end{gathered}
$$

Equation 4-14

$W_{\bar{J}_{P}}, W_{\text {COD Rejection }}$, \& $W_{S F D}$ are the weights assigned to the permeate flux, COD rejection rate and SFD.

It is worth mentioning that the utility function is of the "higher the better" type. If the composite measure (the overall utility) is maximized, the quality characteristics considered for the evaluation of utility will automatically be optimized (maximized or minimized) (Kumar and Singh, 2014).

\subsubsection{Optimum performance prediction}

Once the optimum level of the operating conditions has been selected, it is possible to predict and verify the utility responses using the optimal parameters. The predicted response values under optimum conditions $\left(Y_{\text {opt }}\right)$ can be calculated from Equation 4-15 (Kansal et al., 2006; Ross, 1996) :

$$
Y_{\mathrm{opt}}=m+\sum_{j=1}^{p}\left[\left(m_{i, j}\right)-m\right]
$$

where:

$m$ is the overall mean value of $\mu_{\mathrm{MRSN}}$ over nine trials;

$\left(m_{i, j}\right)$ is the mean value of the quality response under optimum conditions; and $p$ is the number of significant operating parameters that affect the UF process.

The 95\% confidence interval for the confirmation experiments (CICE) must be evaluated at the selected error level according to the following expression (Kansal et al., 2006; Phadke, 1989; Ross, 1996) : 


$$
\mathrm{CI}_{\mathrm{CE}}= \pm \sqrt{F_{\alpha}\left(1, f_{e}\right) \times M S_{e}\left(\frac{1}{n_{e f f}}+\frac{1}{R}\right)}
$$

where, $F_{\alpha}\left(1, f_{e}\right)$ is the F-ratio at a confidence level of $(1-\alpha)$ against a DOF equal to one and an error degree of freedom $f_{e}$ and,

$$
n_{e f f}=\frac{N}{1+(\text { DOF of all factors used to estimate the mean })}
$$

Equation 4-17

where:

$N$ is the number of experiments;

$R$ is the number of repetitions;

$n_{\text {eff }}$ is the effective sample size; and

$M S_{e}$ is the error variance.

\subsubsection{Analysis of variance (ANOVA)}

In order to determine the relative importance of the factors, ANOVA was employed by calculating the sum of squares (SS), degrees of freedom (DOF), mean of square $(M S)$, associated F-test of significance $(F)$ and percentage contribution $(P \%)$ as follows (Montgomery, 2008) as indicated in the following equations :

$$
\mathrm{SS}_{\mathrm{A}}=\left(\sum_{\mathrm{i}=1}^{\mathrm{k}_{\mathrm{A}}} \frac{\mathrm{A}_{\mathrm{i}}^{2}}{\mathrm{n}_{\mathrm{A}_{\mathrm{i}}}}\right)-\frac{\mathrm{T}^{2}}{\mathrm{~N}}
$$

Equation 4-18

where:

$k_{A}$ is the number of the levels of the factors;

$A, n_{A_{i}}$ is the number of all observations at level $i$ of factor $A$;

$A_{i}$ is the sum of all observations of level $i$ of factor $A$;

$T$ is the sum of all observations; and

$N$ is the number of experiments.

The SS of error is computed using the following equations:

$$
S S_{e}=S S_{T}-\left(S S_{A}+S S_{B}+\cdots\right)
$$

Equation 4-19

where, $S S_{T}$ is the total $S S$ : 
Where, $y_{i}$ is the observation of $i$.

$$
S S_{T}=\sum_{i=1}^{N} y_{i}^{2}-\frac{T^{2}}{N}
$$

Equation 4-20

The total $D O F$ is defined as $N-1$, and the DOF for each factor is estimated by $D O F_{A}=$ $k_{A}-1$.

$F-$ value is calculated from the following Equation 4-21:

$$
F_{A}=\frac{M S_{A}}{M S_{e}}
$$

$M S_{A}$ is calculated by dividing the sum of squares by the degrees of freedom of factor $A$ and $M S_{e}$ is the variance of error.

The percentage contribution $P(\%)$ for each factor is defined as the portion of total observed variance in the experiment for each significant factor, it is calculated by dividing the source's net variation ( $\left.\mathrm{S}^{\prime}\right)$ by $S S_{T}$, which given as follows:

$$
P(\%)=\frac{S S_{A}-\left(D O F_{A} \times M S_{e}\right)}{S S_{T}} \times 100
$$

Equation 4-22

Where:

$$
S_{A}^{\prime}=S S_{A}-\left(D O F_{A} x M S_{e}\right)
$$

Equation 4-23

\subsection{Results and discussion}

\subsubsection{Design of experiments and experimental results}

As previously mentioned, permeability tests were carried out prior to each Taguchi experiment with pure water as the feed, in order to determine the intrinsic resistance of the membrane $(\mathrm{Rm})$ for each membrane used, as illustrated in Figure 4-2 


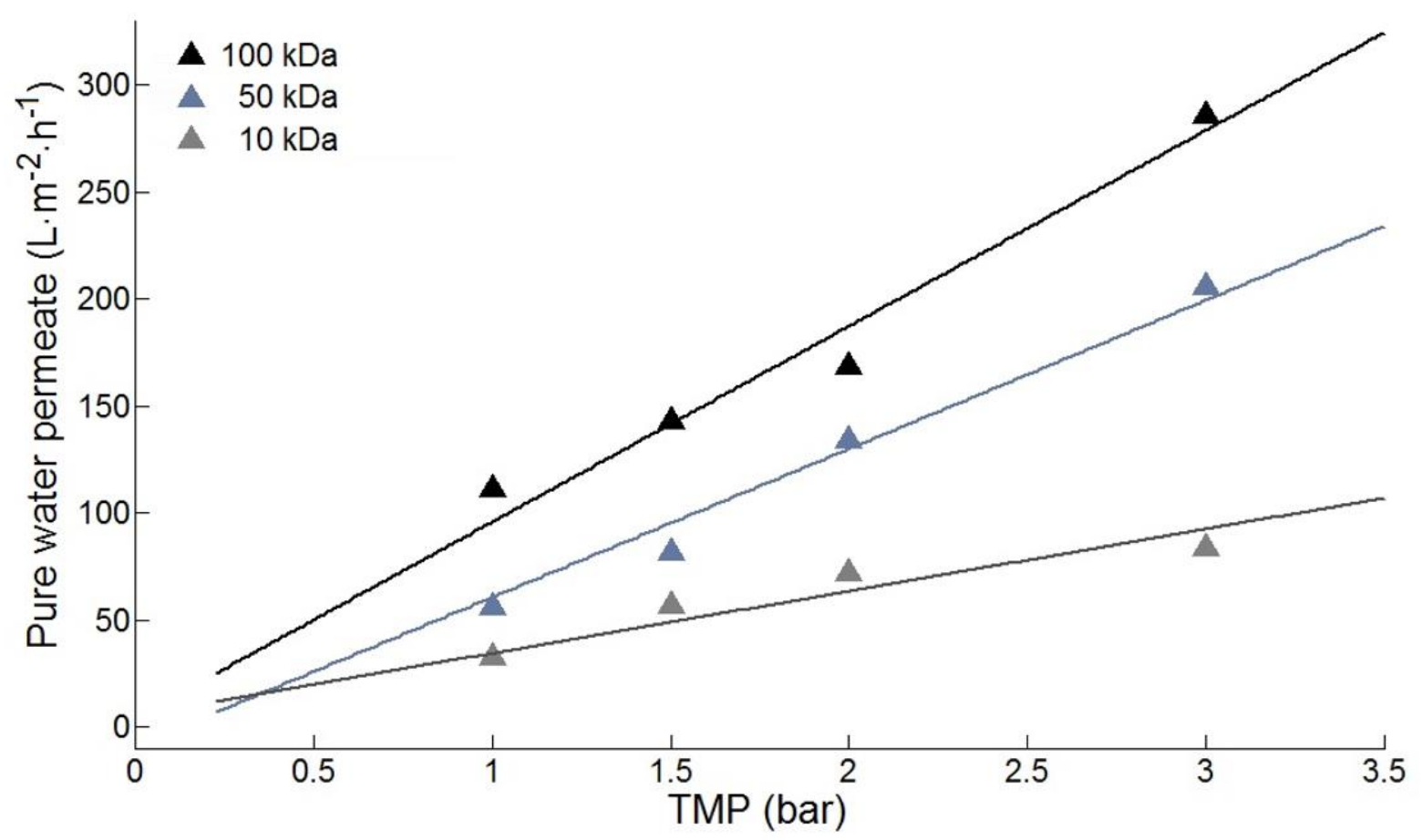

Figure 4-2 - Volumetric flux as a function of transmembrane pressure for PES membranes of different MWCO $\left(T=22.5^{\circ} \mathrm{C}\right)$.

The specific resistance values obtained from the permeability test (Equation 3-2) for the membranes of 10,50 and $100 \mathrm{kDa}$ were $3.46 \times 10^{12}, 4.56 \times 10^{12}$ and $9.88 \times 10^{12} \mathrm{~m}^{-1}$, respectively.

Measurements were taken after 120 min of the UF process, as this is the point when quasi-stationary permeate flux was achieved. The values for the average permeate flux, COD rejection rate and the cumulative flux decline caused by membrane fouling for each trial experiment according to the Tagucchi design is shown in Table 4-4.

The highest average permeate flux was obtained in Trial $8\left(\bar{J}_{P}=95.16 \mathrm{~L} \cdot \mathrm{m}^{-2} \cdot \mathrm{h}^{-1}\right)$ and the lowest value was obtained in Trial $1\left(\bar{J}_{P}=15.23 \mathrm{~L} \cdot \mathrm{m}^{-2} \cdot \mathrm{h}^{-1}\right)$. The corresponding average flux decline indices were respectively $\overline{\mathrm{FD}}=44.87 \%$ and $\mathrm{a} \overline{\mathrm{FD}}=14.0 \%$. 
Table 4-4 - Taguchi orthogonal array $L_{9}\left(3^{4}\right)$ for the operating parameters and experimental response parameters.

\begin{tabular}{|c|c|c|c|c|c|c|c|c|c|c|c|c|c|}
\hline \multirow{4}{*}{$\begin{array}{c}\text { Trial } \\
\mathrm{n}^{\circ}\end{array}$} & \multicolumn{4}{|c|}{ "Factors (parameters) } & \multicolumn{9}{|c|}{ Responses } \\
\hline & \multirow{3}{*}{$\begin{array}{l}\text { TMP } \\
\text { (bar) }\end{array}$} & \multirow{3}{*}{$\begin{array}{l}\text { CFV } \\
(\mathrm{m} / \mathrm{s})\end{array}$} & \multirow{3}{*}{$\begin{array}{c}\mathrm{T} \\
\left({ }^{\circ} \mathrm{C}\right)\end{array}$} & \multirow{3}{*}{$\begin{array}{l}\text { Cut-off } \\
\text { (kDa) }\end{array}$} & \multirow{2}{*}{\multicolumn{3}{|c|}{$\begin{array}{c}\bar{J}_{P} \\
\left(\text { L. } \mathrm{m}^{-2} \mathrm{~h}^{-1}\right)\end{array}$}} & \multirow{2}{*}{\multicolumn{3}{|c|}{$\begin{array}{c}\text { COD } \\
\text { rejection (\%) }\end{array}$}} & \multirow{2}{*}{\multicolumn{3}{|c|}{ SFD }} \\
\hline & & & & & & & & & & & & & \\
\hline & & & & & $\overline{\mathrm{R} 1}$ & $\overline{\mathrm{R} 2}$ & "R3 & $\overline{\mathrm{R} 1}$ & R2 & "R3 & 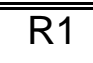 & "R2 & R3 \\
\hline 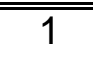 & 1.0 & 0.463 & 15.0 & 10 & 15.23 & 25.74 & 15.97 & 40.25 & 48.9 & 46.85 & 2.92 & 2.73 & 2.80 \\
\hline 2 & 1.0 & 0.752 & 22.5 & 50 & 29.47 & 32.85 & 29.18 & 38.85 & 35.83 & 34.23 & 4.90 & 4.59 & 3.99 \\
\hline 3 & 1.0 & 1.041 & 30.0 & 100 & 45.15 & 42.07 & 47.79 & 41.83 & 41.77 & 42.85 & 6.19 & 5.98 & 6.18 \\
\hline 4 & 2.0 & 0.463 & 22.5 & 100 & 72.04 & 69.67 & 74.30 & 36.92 & 34.23 & 33.75 & 8.07 & 7.68 & 7.06 \\
\hline 5 & 2.0 & 0.752 & 30.0 & 10 & 49.54 & 39.02 & 41.43 & 50.42 & 50.96 & 51.96 & 4.29 & 5.97 & 3.99 \\
\hline 6 & 2.0 & 1.041 & 15.0 & 50 & 57.79 & 67.81 & 53.69 & 47.69 & 46.25 & 46.85 & 3.77 & 4.22 & 4.56 \\
\hline 7 & 3.0 & 0.463 & 30.0 & 50 & 59.14 & 59.59 & 73.57 & 40.46 & 41.37 & 40.68 & 8.29 & 7.94 & 8.46 \\
\hline 8 & 3.0 & 0.752 & 15.0 & 100 & 82.50 & 90.55 & 95.16 & 43.75 & 43.85 & 42.05 & 9.73 & 9.16 & 9.21 \\
\hline 9 & 3.0 & 1.041 & 22.5 & 10 & 48.11 & 50.32 & 49.30 & 52.5 & 53.46 & 55.38 & 5.65 & 4.81 & 5.46 \\
\hline
\end{tabular}

* R1, R2 and R3 is the number of repetitions for each trial. 

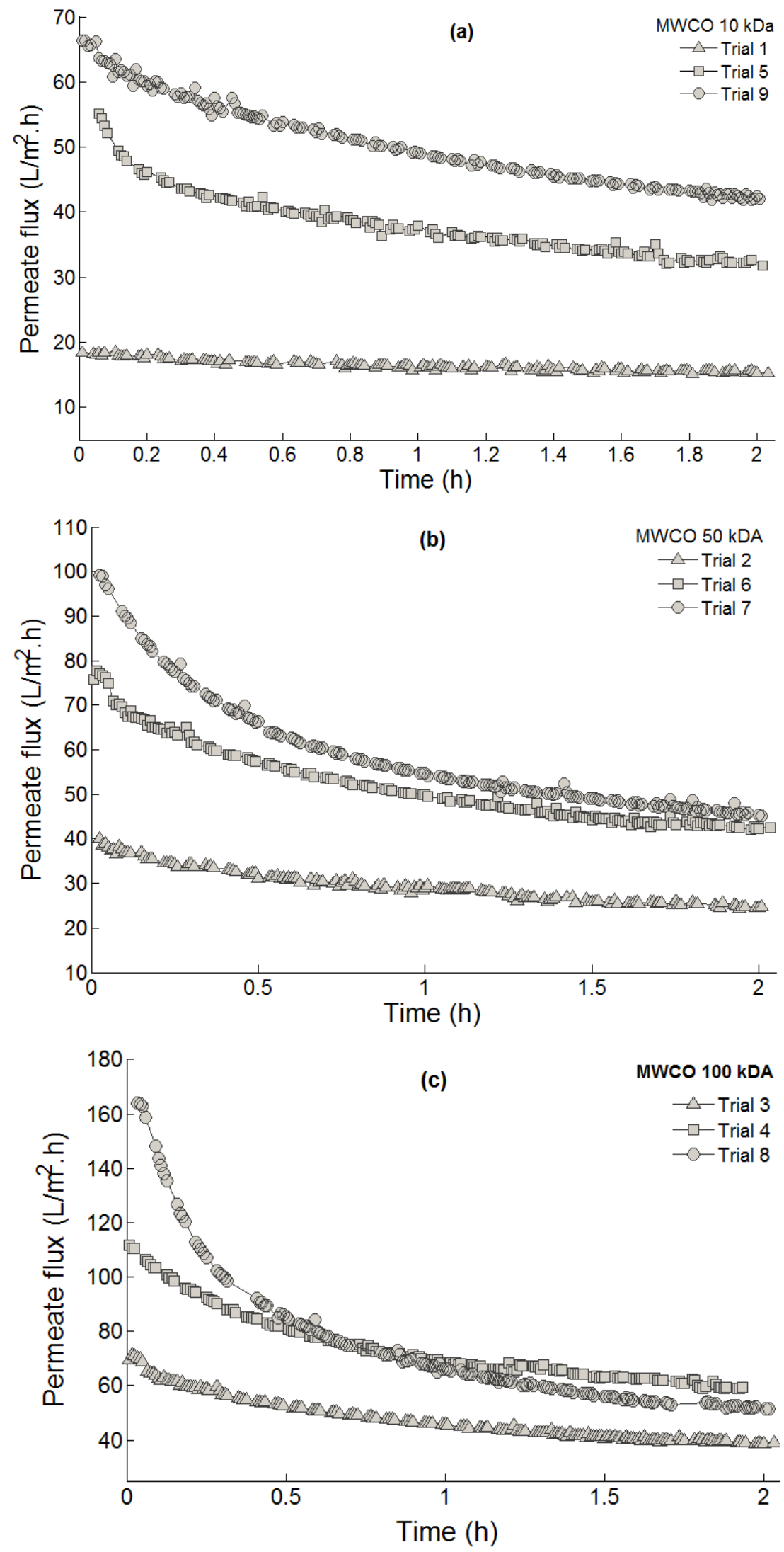

Figure 4-3 - Profile of the permeate flux through the operating time for each MWCO: (a) 10 $\mathrm{kDa}$, (b) $50 \mathrm{kDa}$, and (c) $100 \mathrm{kDa}$. 
Figure 4-3 shows the permeate flux during the UF of PMTE for all the trials carried out for Taguchi DOE (Table 4-3). From the Figure 43 it can be seen that for the same MWCO, the permeate flux decreased with increasing TMP in all trials because of the membrane fouling. Also, it can be observed that the decline of permeate flux can be divided into two stages. At beginning of the process, the flux declined very quickly, mainly in the trials that worked with higher TMP and MWCO, due to the membrane pores becoming blocked more rapidly by adsorption and the accumulation of dissolved and colloidal substances. Furthermore, immediately after pore blockage, the permeate flux continued to decline due to the formation and growth of a cake layer on the membrane surface, when the permeate flux declined more slowly until reaching a quasi-stationary state (Song, 1998b).

In addition, an increase in TMP and CFV can be observed in Fig. 4-3 and Table 4-4 that led to a higher initial permeate flux due to a higher hydraulic driving force (according to Darcy's law) and adequate turbulence of fluid flow, this may have been responsible for removing the concentrated layer of precipitations on the membrane surface (Mulder, 1996; Wu et al., 2019; Xu et al., 2010).. On the other hand, an increase in the TMP means that more colloidal and dissolved substances accumulate on the membrane surface and are absorbed inside in the membrane pores. The cake layer could form at higher TMP, resulting in an increase in the flux decline caused by fouling resistance (Seyed Shahabadi and Reyhani, 2014).

\subsubsection{Taguchi results}

The corresponding $\mathrm{S} / \mathrm{N}$ ratio in decibels $(\mathrm{dB})$ for the response parameters in different trials are listed in Table 4-5.

In order to analyze the influence of each factor on the response variable, the $\mathrm{S} / \mathrm{N}$ ratio for a single factor can be determined by averaging the $\mathrm{S} / \mathrm{N}$ ratios at their levels. The range of the effect for each factor $(\Delta s)$ is calculated as the difference between the two readings, the higher the range, the stronger the effect of the factor, in other words, it shows which parameter has the greatest effect on the response. 
Table 4-5 - Signal-to-noise results (mean \pm standard deviation (SD), three repetitions for each experimental condition).

\begin{tabular}{cccc}
\hline \hline Trial $n^{\circ}$ & $\begin{array}{c}\bar{J}_{P} \\
\text { S/N ratio }\end{array}$ & $\begin{array}{c}\text { COD rejection } \\
\text { S/N ratio }\end{array}$ & $\begin{array}{c}\text { SFD } \\
\text { S/N ratio }\end{array}$ \\
\cline { 2 - 4 } & $\mathrm{Y}_{1}$ & $\mathrm{Y}_{2}$ & $\mathrm{Y}_{3}$ \\
\hline \hline 1 & $24.88 \pm 2.52$ & $33.50 \pm 0.25$ & $-8,98 \pm 0.28$ \\
2 & $29.65 \pm 0.57$ & $31.16 \pm 0.56$ & $-13,13 \pm 0.94$ \\
3 & $33.03 \pm 0.55$ & $32.49 \pm 0.12$ & $-15,73 \pm 0.16$ \\
4 & $37.14 \pm 0.28$ & $30.85 \pm 0.42$ & $-17,64 \pm 0.59$ \\
5 & $32.60 \pm 1.09$ & $34.17 \pm 0.13$ & $-13,67 \pm 1.86$ \\
6 & $35.41 \pm 1.04$ & $33.43 \pm 0.14$ & $-12,46 \pm 0.82$ \\
7 & $36.01 \pm 1.08$ & $32.22 \pm 0.10$ & $-18,31 \pm 0.28$ \\
8 & $39.01 \pm 0.67$ & $32.71 \pm 0.20$ & $-19,43 \pm 0.29$ \\
9 & $33.84 \pm 0.19$ & $34.61 \pm 0.24$ & $-14,52 \pm 0.74$ \\
\hline \hline
\end{tabular}

The mean $\mathrm{S} / \mathrm{N}$ ratio response curves for each factor and the levels for the responses are shown in Figure 4-4, it is worth mentioning that the peak points in these plots correspond to the optimum condition.

a)

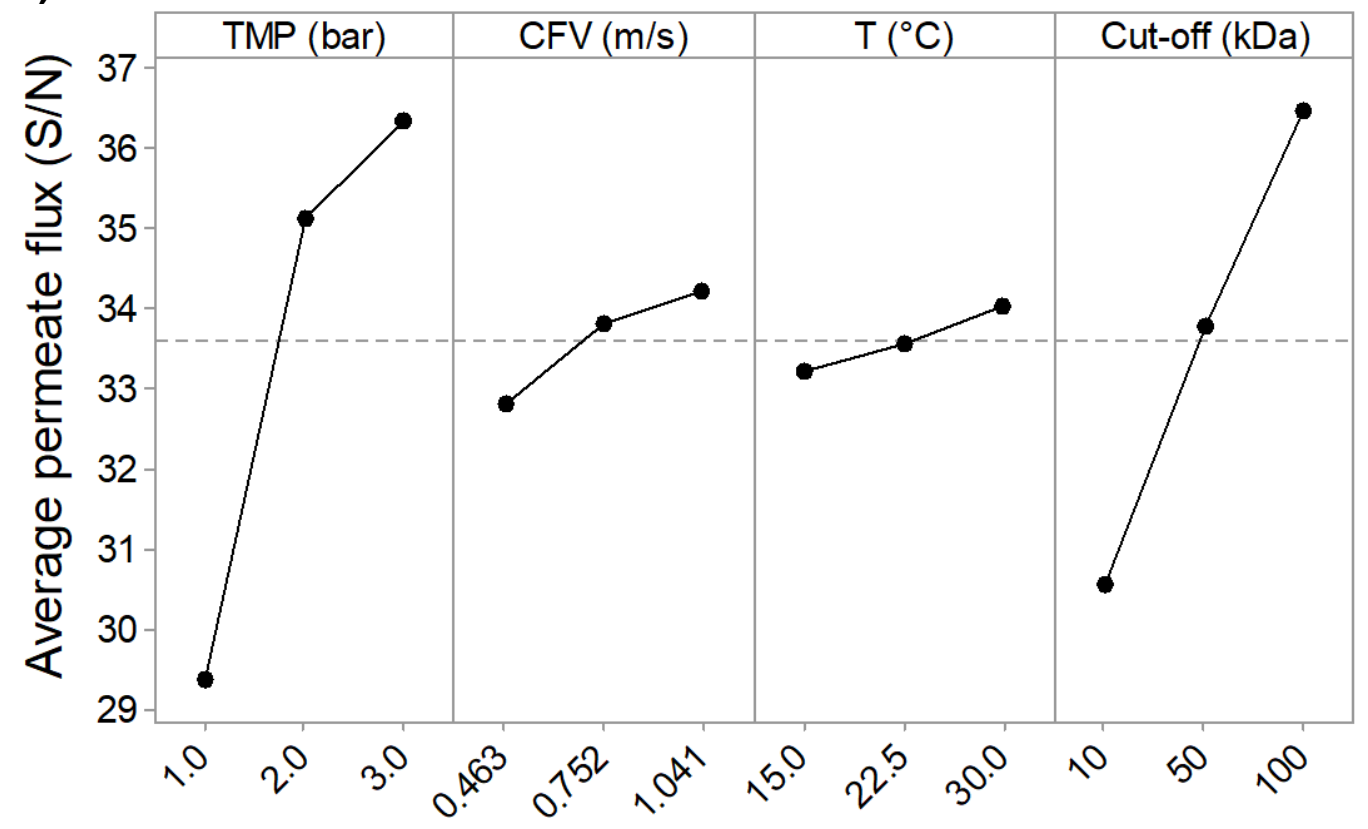



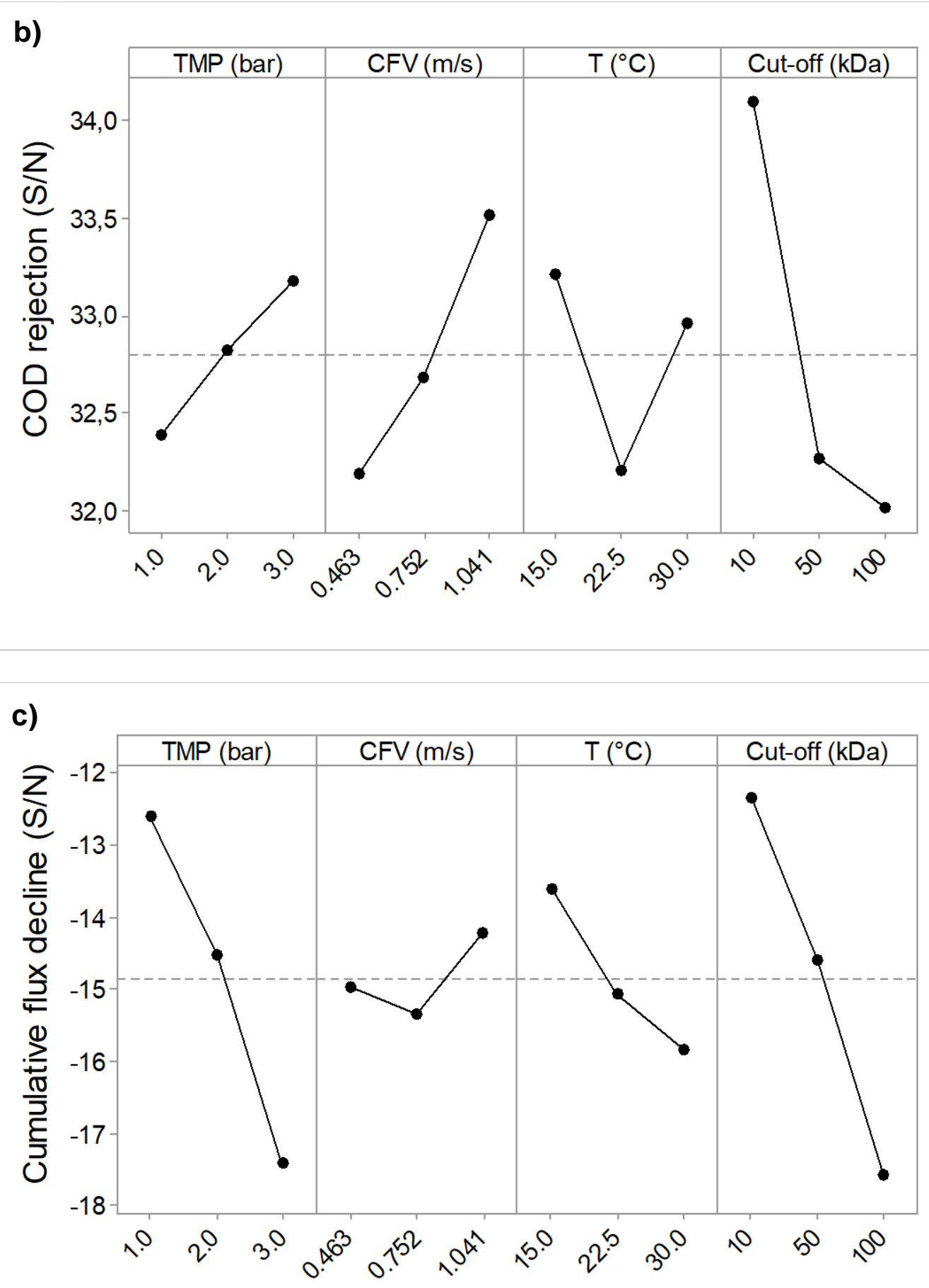

Figure 4-4 - Mean effect curves for $\mathrm{S} / \mathrm{N}$ ratios for a) the average permeate flux, b) COD rejection rate, and $\mathrm{c}$ ) the cumulative flux decline (SFD).

As can be seen in Figure 4-4, the variations $(\Delta s)$ around the mean $S / N$ value were different for different factors. TMP and membrane MWCO had the greatest effect on the average permeate flux as they have the steepest slope, $\Delta s=7.10$ and 5.95 respectively. 
CFV was the next one with a $\Delta s=1.42$, and temperature had the lowest variation around the mean $S / N$ value, with $\Delta s=0.78$. Besides that, from Table 4-5, the overall mean value was calculated as $33.59(\mathrm{~dB})$ from all the trial experiment results. It can be observed that the increase in $\bar{J}_{P}$ was stronger when the TMP changes from 1.0 to 2.0 bar than when it changes over the range from 2.0 to $3.0 \mathrm{bar}$, this could be due to the effects of polarization and cake compaction on the membrane surface. For CFV, the slope of the line between the different levels are not the same $(0.463-0.752 \mathrm{~m} / \mathrm{s}$ is higher than at $0.752-1.041 \mathrm{~m} / \mathrm{s}$ ), but with a small variation around the $\bar{J}_{P}$ value. Also, it can be seen for MWCO and temperature that the slopes from 10 to $100 \mathrm{kDa}$ and 15 ${ }^{\circ} \mathrm{C}$ to $30^{\circ} \mathrm{C}$ are almost the same. Therefore, the maximum average permeate flux can be obtained for 3.0 bar, $100 \mathrm{kDa}, 1.041 \mathrm{~m} / \mathrm{s}$ CFV and high temperature $\left(30^{\circ} \mathrm{C}\right)$.

Under optimum COD rejection conditions, a positive and larger value of $S / N$ is desired (Figure 4-4 (b)). In this study when comparing the $\mathrm{S} / \mathrm{N}$ between different factors, it was showed that the most significant variation around the mean $\mathrm{S} / \mathrm{N}$ ratios is observed for MWCO and CFV ( $\Delta s=2.07$ and 1.32 respectively). Also, it can be seen that the $S / N$ ratio increased with TMP and CFV and decreased with MWCO. Hence maximum COD removal occurred at higher TMP and CFV (3.0 bar and $1.041 \mathrm{~m} / \mathrm{s})$, and $10 \mathrm{kDa}$. It is worth mentioning that the DCS found in the PMTE are a mixture of high and low molecular weight organic and inorganic compounds, thus the contribution of the smaller particles gives lower rejection during high MWCO UF in membranes with 50 and $100 \mathrm{kDa}$ MWCO.

Figure 4-4 (c), shows that an increase in TMP, temperature and MWCO caused a decrease in the $S / N$ ratio for $S F D$, that is to say, these factors intensified the membrane fouling effects. On the other hand, an increase in CFV induced an increase in the SN ratio, this resulted in a decrease in the fouling effect. The highest variations around the mean $S / N$ ratio were found for MWCO and TMP ( $\Delta s=5.21$ and 4.81). Generally, the permeate flux increased with increasing MWCO and TMP. However, under these operating conditions, DCS in PMTE can easily pass through the membrane and blocking can be observed within the pores and on the membrane surface.

In addition, the highest $S / N$ ratio for the SFD factor $(-8.98 \pm 0.28)$ was achieved in Trial 1 , whereas the lowest $S / N$ ratio $(-19.43 \pm 0.29)$ was obtained in Trial 8 . The optimum conditions that minimized the SFD (lowest level of fouling) were obtained at the lowest 
TMP (1.0 bar), highest CFV $(1.041 \mathrm{~m} / \mathrm{s})$, at temperature $15^{\circ} \mathrm{C}$ and at the smallest MWCO (10 kDa).

\subsubsection{ANOVA results}

A statistical analysis of variance (ANOVA) was carried out to quantitatively determine the effect of each factor on the UF process indicators, with the aim of estimating whether the process parameters are statistically significant or not on the results responses. The ANOVA results are shown in Table 4-6.

Table 4-6 - Analysis of variance (ANOVA) results for average permeate flux, COD rejection, and SFD for each factor.

\begin{tabular}{|c|c|c|c|c|c|c|}
\hline Responses & Factors & DOF & $\overline{\text { SS }}$ & $\overline{\mathrm{MS}}$ & F-value & p-value \\
\hline \multirow{6}{*}{$\begin{array}{c}\text { Average } \\
\text { permeate flux }\end{array}$} & "TMP (bar) & $\overline{22}$ & 6357.68 & 3178.84 & $=114.01$ & 0.000 \\
\hline & CFV $(\mathrm{m} / \mathrm{s})$ & 2 & 54.76 & 27.38 & 0.98 & 0.394 \\
\hline & Temperature $\left({ }^{\circ} \mathrm{C}\right)$ & 2 & 179.15 & 89.58 & 3.21 & 0.064 \\
\hline & MWCO (kDa) & 2 & 4546.30 & 2273.15 & 81.52 & 0.000 \\
\hline & Error/others & 18 & 501.90 & 27.88 & & \\
\hline & Total & 26 & 11639.80 & & & \\
\hline \multirow{7}{*}{$\begin{array}{l}\text { COD } \\
\text { rejection }\end{array}$} & TMP (bar) & 2 & 73.55 & 36.78 & 21.70 & 0.000 \\
\hline & $\mathrm{CFV}(\mathrm{m} / \mathrm{s})$ & 2 & 198.21 & 99.11 & 58.47 & 0.00 \\
\hline & & & & & & \\
\hline & Temperature $\left({ }^{\circ} \mathrm{C}\right)$ & 2 & 82.58 & 41.29 & 24.36 & 0.00 \\
\hline & MWCO (kDa) & 2 & 607.95 & 303.98 & 17.34 & 0.00 \\
\hline & Error/others & 18 & 30.51 & 1.70 & & \\
\hline & Total & 26 & 992.79 & & & \\
\hline \multirow{6}{*}{ SFD } & TMP (bar) & 2 & 46.48 & 23.24 & 96.57 & 0.000 \\
\hline & $\mathrm{CFV}(\mathrm{m} / \mathrm{s})$ & 2 & 6.12 & 3.06 & 12.72 & 0.000 \\
\hline & Temperature $\left({ }^{\circ} \mathrm{C}\right)$ & 2 & 3.80 & 1.90 & 7.89 & 0.003 \\
\hline & MWCO (kDa) & 2 & 52.95 & 26.47 & 110.00 & 0.000 \\
\hline & Error/others & 18 & 4.33 & 0.24 & & \\
\hline & Total & 26 & 113.68 & & & \\
\hline
\end{tabular}


In order to determine the qualitative significance of each factor on the responses, Fisher's test (F-value) was employed in the ANOVA analysis. An F-value is defined as the ratio of variance due to the effect of a factor on the variance due to the inherent error in the system (Ennil Köse, 2008). The F-value calculated using Equation 4-21 was compared to the critical F-value (Fcr) (Montgomery, 2008). A calculated F-value lower than the Fcr-value means that the effect of that factor is not significant at the selected confidence level or/and it is not important in comparison with the error term. In this study, with four factors, three levels for each factor and three repetitions at each trial condition, the DOF for each factor is 2 and the DOF for the error is 18 , so the Fcrvalue at a confidence level of $95 \%$ is equal 3.55 .

In accordance with the ANOVA table, for average permeation flux, the F-value for TMP and MWCO (114.1 and81.52, respectively) are greater than the Fcr-value. This means that the variance of these factors is significant compared with the variance of error and they have a significant effect on the response. On the other hand, temperature and CFV had no meaningful qualitative effect on $\bar{J}_{P}$, as their F-values were less than the Fcr-value. Furthermore, COD rejection rate and SFD presented F-values for all factors greater than the Fcr-value which means that the effect of these factors is significant at the $95 \%$ confidence level and they have a meaningful qualitative effect on responses. Another statistical tool that is helpful for qualitative evaluation in ANOVA, is thep-value, which is used to indicate which factors had a significant effect on the responses. The smaller the $p$-value at an a level of significance, the more significant is the corresponding factor (Cochran, 1992; Myers et al., 2016). In this study, based on pvalues at the $95 \%$ confidence level $(\alpha=0.05)$, all the factors had a statistically significant ( $p$-value $<0.05$ ) effect on the COD rejection rate and SFD. For $\bar{J}_{P}, C F V$ and temperature had a p-value higher than 0.05 (see Table 4-6), thus the effect may be regarded as insignificant and it can be ignored.

The use of the percentage contribution (P\%) in ANOVA analysis is helpful for the quantitative evaluation of the factorial effects of the performance indicators. It was calculated using Equation 4-22 as described in the Materials and Methods section. The $\mathrm{P} \%$ of all factors on average permeate flux, COD rejection rate, and SFD are shown in Figure 4-5, to determine the order of importance of the factors. 


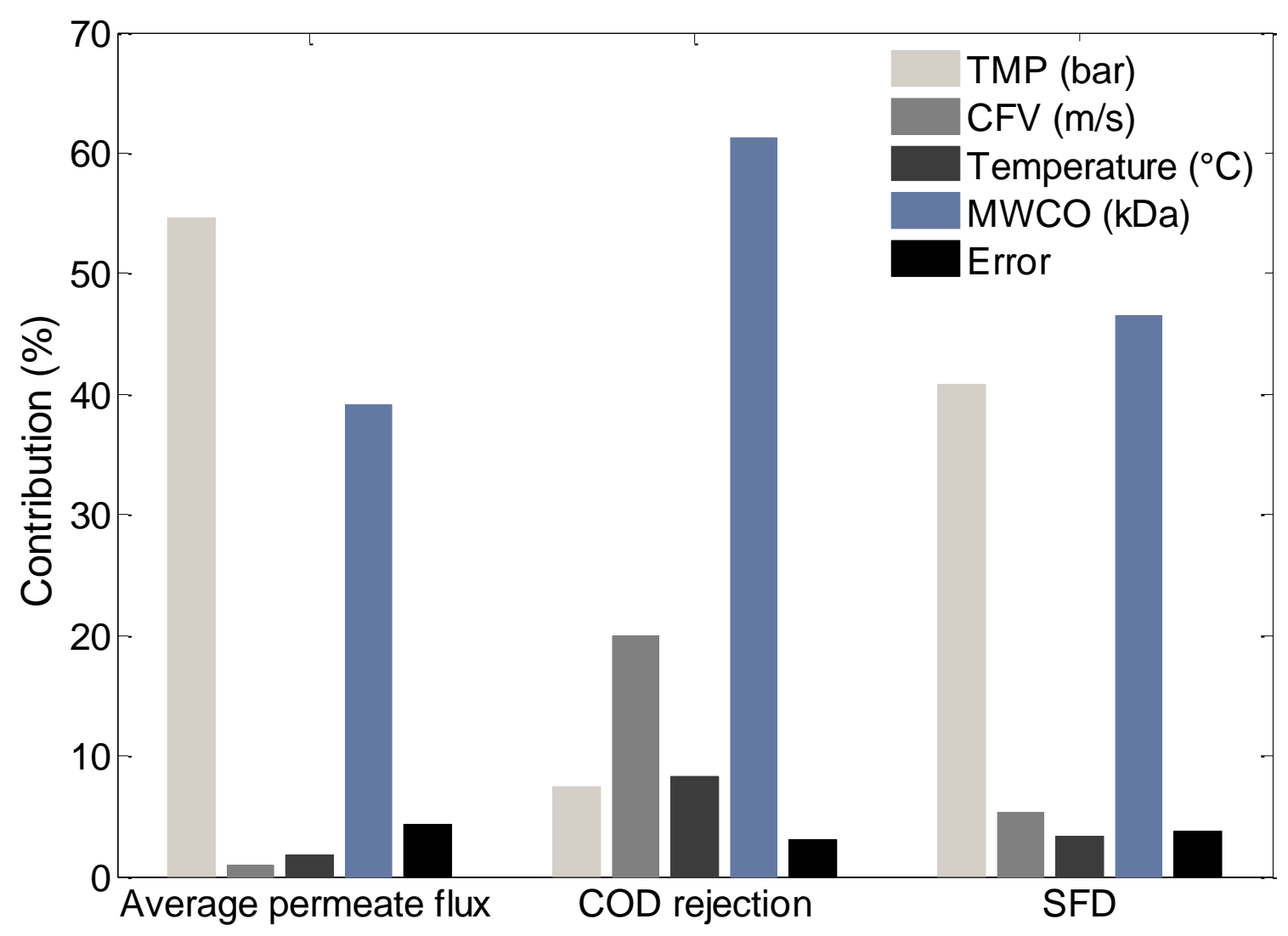

Figure 4-5 - ANOVA results for the percentage contribution of each factor to the response processes.

Therefore, TMP (P\% = 54.62) was the most important factor on average permeate flux, as higher pressure resulted in higher permeate flux, according to Darcy's law (Mu Ider, 1996). MWCO ( $P \%=39.06)$ was the second most important factor, followed by temperature and CFV. For the COD rejection rate, the order of importance for the factors is as follows MWCO > CFV > temperature > TMP. In addition, MWCO and TMP (46.57\% and $40.89 \%$, respectively) were the most significant parameters on membrane fouling resistance, followed by the CFV and temperature. TMP and MWCO were the most important factors for responses. Higher TMP and MWCO resulted in higher permeate flux. However, more intensive flux decline, due to membrane fouling, occurred at higher permeate flux.

It is important to mention that the values reported as due to error resulting from uncontrollable noises should be below 50\% for the results to be reliable (Gönder et al., 2010; Pourjafar et al., 2013; Reyhani et al., 2015). Therefore, it can be seen in Figure 4-5 that for average permeate flux, COD rejection rate and SFD, the error values are 
$4.31 \%, 3.07 \%$ and $3.81 \%$, respectively. This means that the error values for the experiment are not significant for the UF process.

4.4.4 Optimum results obtained from the Taguchi method and utility concept The aim of optimizing the process was to find the operating conditions that led to a maximum average permeate flux and COD rejection rate based on the levels that gave the highest $\mathrm{S} / \mathrm{N}$ ratios for the factors (desirable values) and to minimize the SFD, that is, the levels that gave the smallest $\mathrm{S} / \mathrm{N}$ ratios (adverse values).

4.4.4.1 Analysis of individual response optimization

After identifying the optimum operating conditions, the optimal responses were predicted individually using the Taguchi method and ANOVA. Table 4-7 presents the Taguchi prediction results for the optimum conditions for average permeate flux, COD rejection rate and SFD.

Table 4-7 - Individual Taguchi predictions for average permeate flux, COD rejection rate and SFD.

\begin{tabular}{ccccc}
\hline \hline & $\begin{array}{c}\text { Optimum operating } \\
\text { conditions }\end{array}$ & $\begin{array}{c}\text { Significant } \\
\text { factors }\end{array}$ & \multicolumn{2}{c}{ Predicted optimal responses } \\
\hline \hline Response & & & S/N ratio & \\
parameters & & $(\mathrm{dB})$ & Main \\
$\bar{J}_{P}$ & A3, B3, C3, D3 & A, D & 38.19 & $81.20{\mathrm{~L} . \mathrm{m}^{-2} \mathrm{~h}^{-1}}^{-}$ \\
COD Rejection & A3, B3, C1, D1 & A, B, C, D & 35.26 & $57.92 \%$ \\
SFD & A1, B3, C1, D1 & A, B,C,D & -5.10 & 1.80 \\
\hline \hline
\end{tabular}

According to the Taguchi predictions, the average permeate flux at TMP $3.0 \mathrm{bar}$, CFV $0.752 \mathrm{~m} / \mathrm{s}$, at $22.5^{\circ} \mathrm{C}$ and with a $100 \mathrm{kDa}$ MWCO, achieves $81.20 \mathrm{~L} / \mathrm{m}^{2} / \mathrm{h}$. The COD rejection rate predicted under optimu m conditions indicates a $57.92 \%$ rejection, higher than any value obtained in the DOE combinations. For the SFD under optimum conditions estimated by the Taguchi method, the minimum SFD predicted is approximately 1.80 , equivalent to a $\overline{F D}$ of $8.65 \%$.

4.4.4.2 Analysis of multi- response optimization

As mentioning above, in order to determine the weight for each response variable, a pair-wise comparison matrix was compiled using the AHP method as presented in Table 4-8. 
Table 4-8 - Pairwise comparison matrix.

\begin{tabular}{cccc}
\hline \hline Response & $\mu_{1}$ & $\mu_{2}$ & $\mu_{3}$ \\
\hline \hline$\mu_{1}$ & 1.0 & 5.0 & 2.0 \\
$\mu_{2}$ & $1 / 5$ & 1.0 & $1 / 4$ \\
$\mu_{3}$ & $1 / 2$ & 4.0 & 1.0 \\
\hline \hline
\end{tabular}

Thus, the weights assigned to response variables were $\mathrm{WJP}=0.568, \mathrm{~W}$ coD Rejection $=$ 0.098 and $\mathrm{W}_{\mathrm{SFD}}=0.334$. The consistency ratio index $(\mathrm{CR})$ is used to evaluate the consistency of AHP estimates. In this case it was calculated as 0.021 , which should be less than the allowed value of $\mathrm{CR}=0.1$, this means that the pairwise comparison matrix was considered acceptable.

The overall utility index for the $\mu_{\text {MRSN }}$ was calculated using Equation 4-11 with values associated with the weights of each response, using the lager the better $(\mathrm{S} / \mathrm{N})$ and the results are presented in Table 4-9.

Table 4-9 - Utility value based on UF responses ( $\bar{J}_{P}$, COD rejection, SFD).

\begin{tabular}{cccc}
\hline \hline & \multicolumn{3}{c}{ Utility value } \\
\cline { 2 - 4 } Trial $\mathrm{n}^{\circ}$ & $\mathrm{R} 1$ & $\mathrm{R} 2$ & $\mathrm{R} 3$ \\
\hline \hline 1 & 13.60 & 16.42 & 13.96 \\
2 & 15.19 & 15.81 & 15.64 \\
3 & 16.69 & 16.43 & 16.99 \\
4 & 18.11 & 18.03 & 18.58 \\
5 & 18.37 & 16.24 & 17.72 \\
6 & 19.45 & 19.89 & 18.53 \\
7 & 17.14 & 17.32 & 18.17 \\
8 & 18.39 & 19.02 & 19.27 \\
9 & 17.46 & 18.16 & 17.32 \\
\hline \hline
\end{tabular}

* R1, R2 and R3 is the number of repetitions of the experiment.

ANOVA analysis was also performed for the multiple response parameters using the utility concept. From Table 4-10, it is clear that when F-value is compared with Fcr (3.55), TMP, MWCO and CFV had a qualitatively significant effect (at a confidence level of $95 \%$ ) on $\mu_{\mathrm{MRSN}}$. The percentage contributions extracted from the ANOVA table were also used to determine the significance of each operating parameter in the process. The $\mathrm{P} \%$ values were arranged as follows: $\mathrm{TMP}>\mathrm{MWCO}>\mathrm{CFV}>$ temperature. 
Therefore, according to the results in Table 4-10, TMP and MWCO were the most important factors in optimizing the multi-response UF system.

Table 4-10 - ANOVA analysis results for multi-response UF (overall utility function).

\begin{tabular}{cccccccc}
\hline \hline Responses & Factors & DOF & SS & MS & F-value & p-value & $\mathrm{P} \mathrm{( \% )}$ \\
\hline \hline \multirow{4}{*}{$\begin{array}{c}\text { Utility } \\
\text { concept }\end{array}$} & TMP $($ bar $)$ & 2 & 38.85 & 19.43 & 35.50 & 0.000 & 60.93 \\
& $\mathrm{CFV}(\mathrm{m} / \mathrm{s})$ & 2 & 5.84 & 2.92 & 5.34 & 0.015 & 9.16 \\
& Temperature $\left({ }^{\circ} \mathrm{C}\right)$ & 2 & 0.94 & 0.47 & 0.86 & 0.440 & 1.47 \\
& & & & & & & \\
& MWCO $(\mathrm{kDa})$ & 2 & 8.28 & 4.14 & 7.57 & 0.004 & 12.99 \\
& Error/others & 18 & 9.85 & 0.55 & & & 15.45 \\
& Total & 26 & 63.76 & & & & 100.0 \\
\hline \hline
\end{tabular}

The optimum operating conditions for the simultaneous response were obtained based on the criteria that both $\bar{J}_{P}$ and COD rejection rate must be maximized and SFD should be minimized. The variation in the overall utility for the operating parameters at different levels is presented in Figure 4-6.

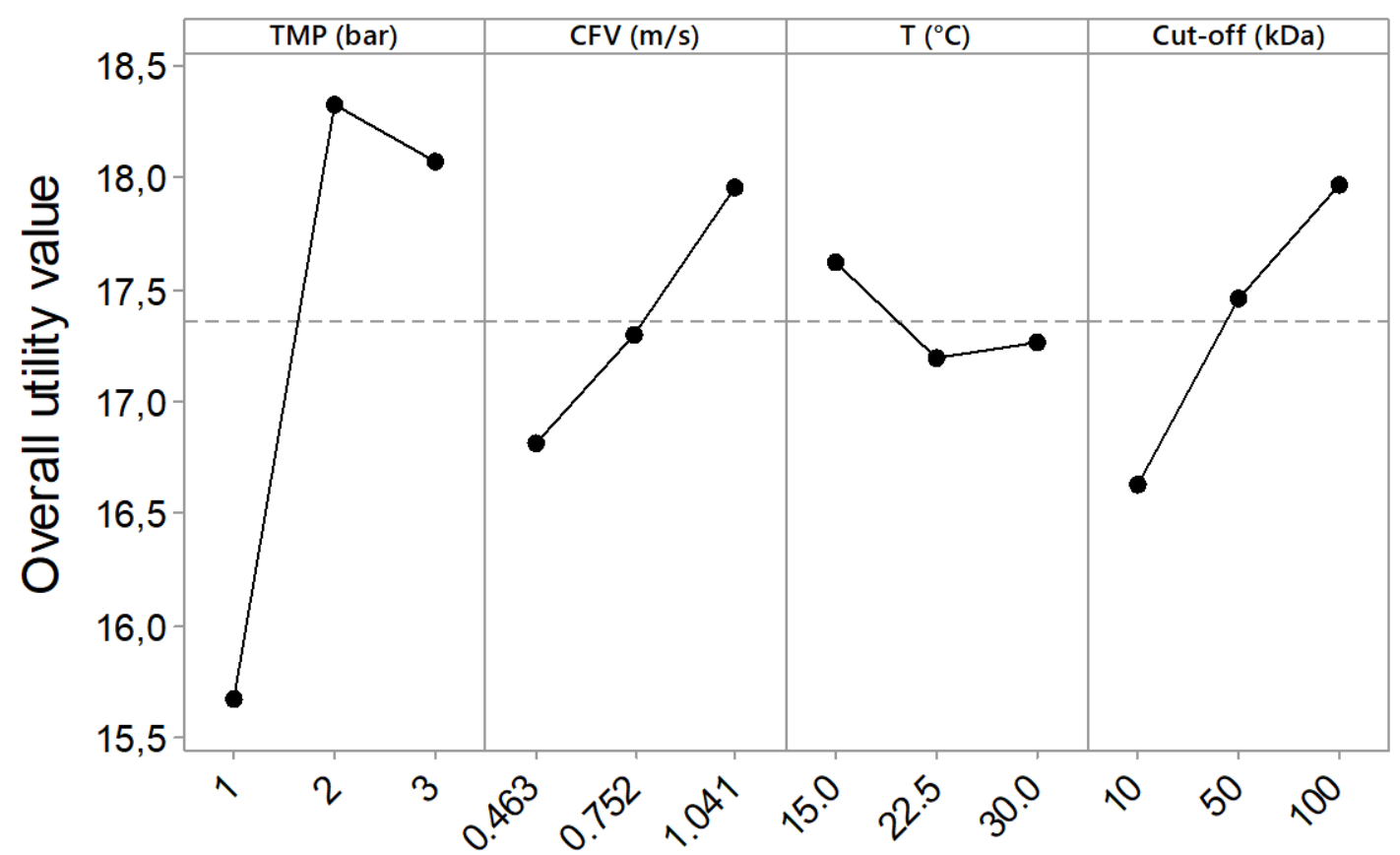

Figure 4-6 - Effect of process parameters on mean utility value $\left(\bar{J}_{P}\right.$; COD rejection rate, SFD).

It is clear from Figure 4-6 that the optimal combination of operating conditions (maximum value of the overall utility) was found at the second level of transmembrane 
pressure (2.0 bar), the second level of cross-flow velocity $(1.041 \mathrm{~m} / \mathrm{s})$, the first level of temperature $\left(15^{\circ} \mathrm{C}\right)$, and third level of MWCO $(100 \mathrm{kDa})$.

Once the optimal levels had been selected the next step was to estimate the multiresponse $\mathrm{S} / \mathrm{N}$ ratio and predict the optimal values for the simultaneous optimization response, calculated using Equation 4-15 and presented in Table 4-11.

Table 4-11 - Optimum conditions for multi-response UF predicted using the utility concept.

\begin{tabular}{cccc}
\hline \hline Method & Response & Optimal conditions & Optimal values \\
\hline \hline \multirow{3}{*}{ Multi - response } & $\mu_{\mathrm{MRSN}}(\mathrm{dB})$ & & 19.82 \\
& $\bar{J}_{P}\left(\mathrm{~L} / \mathrm{m}^{2} \mathrm{~h}\right)$ & & 77.22 \\
& $\mathrm{COD}(\%)$ & A2 B3 C1 D3 & 45.69 \\
& $\mathrm{SFD} / \overline{F D}$ & & $6.24 / 30 \%$ \\
\hline \hline
\end{tabular}

\subsubsection{Confirmation experiment under optimum conditions}

After determining the optimum operating conditions for the overall utility value and the significance of factors, validation experiments (for multi-responses) were carried out at the optimal levels in order to validate the predicted UF responses suggested using the Taguchi method with utility concept (Kaladhar et al., 2011; Ross, 1996).

The observed permeate flux results as a function of time under optimized conditions during the UF of PMTE are plotted in Figure 4-7. As described previously, the flux decline was mainly the result of two phenomenon, pore blocking and cake layer formation, which mostly occurred in the first hour of the process (Reyhani et al., 2015; Sousa et al., 2018). During the first 30 minutes of the UF, the flux decreased by $22.63 \%$. Furthermore, immediately after pore blockage, the permeate flux continued to decline due to the formation and growth of a cake layer until the system approached the quasi-steady state. At the end of the process (after 2 hours), the final permeate flux was about $67.0 \mathrm{~L} / \mathrm{m}^{2} / \mathrm{h}$ and flux decline around $39.72 \%$, which confirms that the membrane fouling took place with a higher rate in the first 30 minutes and at a slower rate when the system had achieved a steady state. Therefore, the observed experimental values of average permeate flux and cumulative flux decline were about $81.15 \mathrm{~L} / \mathrm{m}^{2} / \mathrm{h}$ and 6.01 (SFD equivalent to a $\overline{\mathrm{FD}}$ of $28.96 \%$ ). 


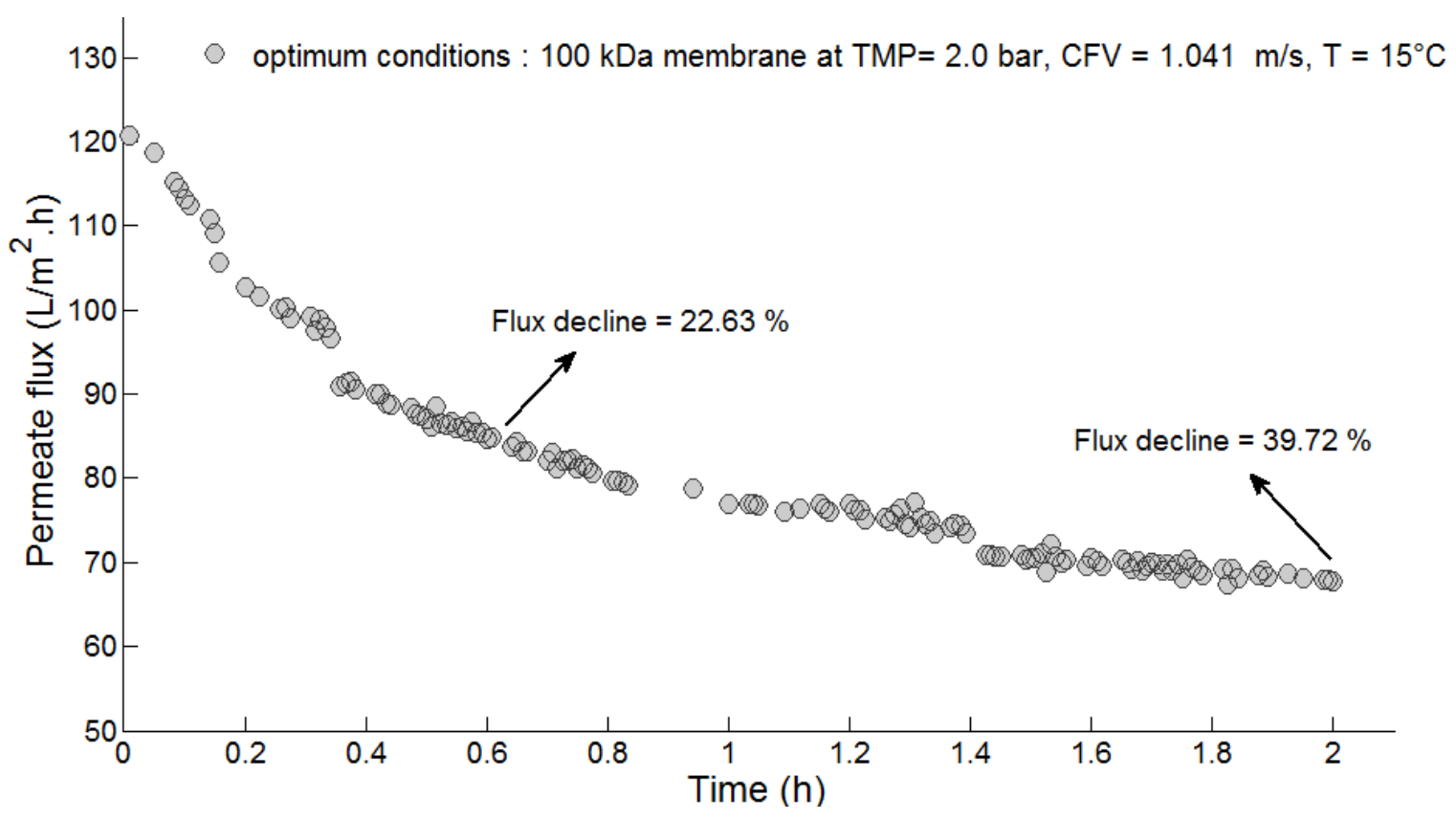

Figure 4-7 - Permeate flux as a function of time under optimized conditions during UF of PMTE: PES $100 \mathrm{kDa}$ membrane at TMP $=2.0 \mathrm{bar}, \mathrm{CFV}=0.752 \mathrm{~m} / \mathrm{s}$, and $\mathrm{T}=15^{\circ} \mathrm{C}$.

The total resistance $\left(R_{t}\right)$ at the end of the 2-hour experiment under optimum conditions was $1.13 .10^{13} \mathrm{~m}^{-1}$, which is formed from: intrinsic membrane resistance $(R m=3.40 \times$ $\left.10^{12} \mathrm{~m}^{-1}\right)$ and resistance of the fouled membrane $\left(R \mathrm{f}=7.91 \times 10^{12} \mathrm{~m}^{-1}\right)$.

In addition, the membrane surface morphologies were observed by FESEM. Figure 4-8 shows the images of the membrane (PES $100 \mathrm{kDa}$ ) before and after the UF experiments were carried out. As can clearly be seen, before UF there is no blocking on the pores and no cake layer on the membrane surface. Figure 4-8 (b)-(c) shows the surface of the membrane fouling after 30 minutes and after 2 hours. In both cases, the images show the existence of pore blocking due to DCS adsorption within the membrane pores and sediments deposited on the surface (cake layer) acting to resist the UF (Reyhani and Hemmati, 2014). Figure 4-8 (d) shows the morphologies of the sediments (foulants) on the membrane. 


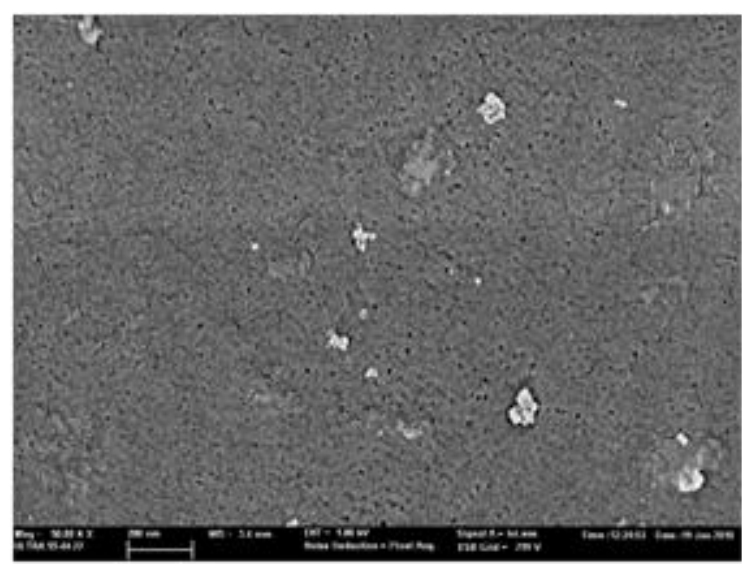

(a)

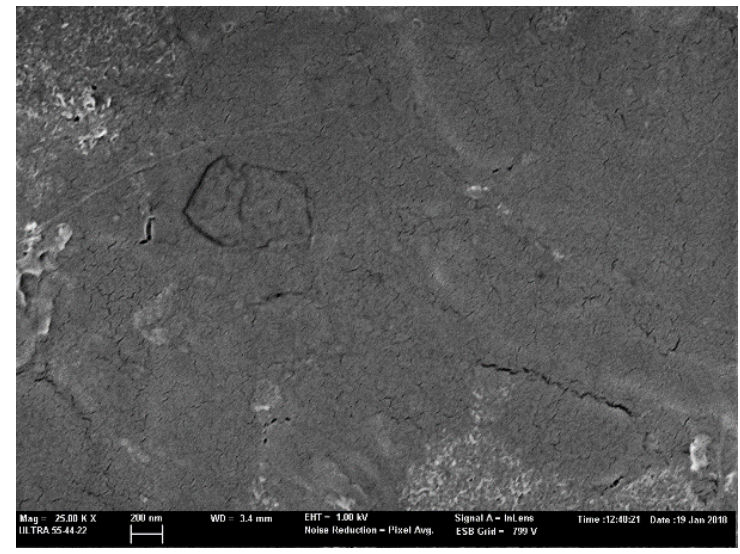

(c)

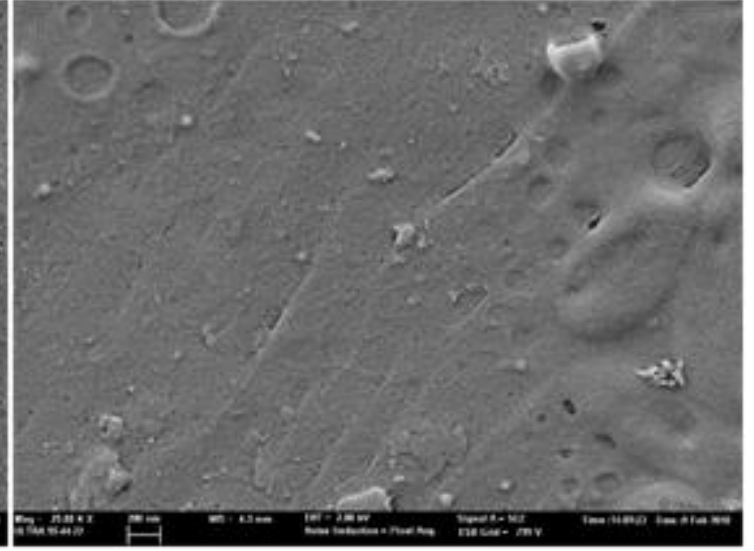

(b)

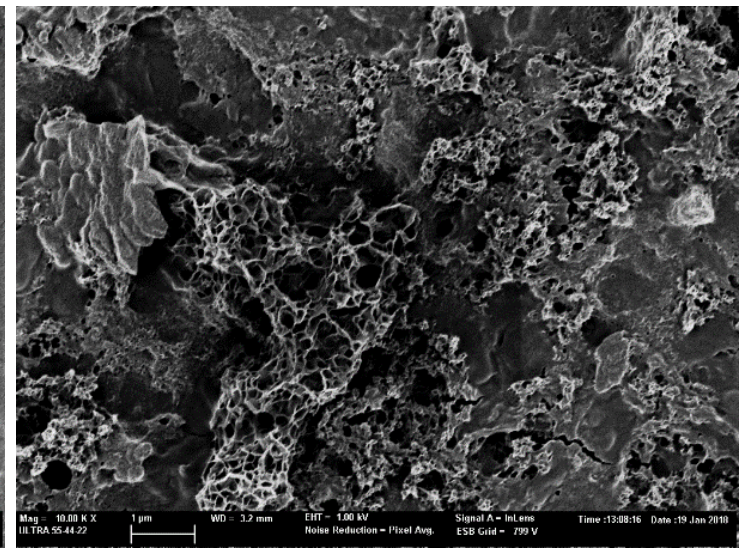

(d)

Figure 4-8 - FESEM image of fresh and fouled membranes (PES $100 \mathrm{kDa}$ ) at different operating times, (a) clean membrane surface, (b) membrane surface fouled after 30 min filtration, (c) at the end of the UF (2 hours) with pore blocking and cake layer (d) membrane foulant sediments.

Furthermore, it can be seen that the membrane was indeed fouled after 30 minutes filtration. However, the FESEM images of the membranes after filtration, at 2 hours, were highly similar to the membranes after 30 minutes filtration. It may, therefore, be concluded that the permeate flux decline might result from the pore blocking as opposed to the formation and growth of the cake layer on the membrane.

Additionally, to verify the permeate applicability for paper mill reuse, the physical and chemical properties of the membane permeate obtained under optimal operational conditions (PES $100 \mathrm{kDa}$ membrane at TMP $=2.0 \mathrm{bar}, \mathrm{CFV}=0.752 \mathrm{~m} / \mathrm{s}$, and $\mathrm{T}=15$ ${ }^{\circ} \mathrm{C}$ ) were compared with treated paper mil effluent used in as feed solution (Table 4-1). The results obtained (retention efficiency) for the physical-chemical characteristics are given in Table 4-12. From the obtained, all properties showed high retention efficiencies and proved the effectiveness of the UF under optimal conditions. 
Table 4-12- Permeate quality (process performance) under optimum conditions, at the end of 2 hours operating.

\begin{tabular}{ccc}
\hline \hline Parameter & $\begin{array}{c}\text { UF Permeate } \\
\text { quality }\end{array}$ & $\begin{array}{c}\text { Percent } \\
\text { removal }(\%)\end{array}$ \\
\hline \hline TSS (g/L) & 0.0002 & 99.57 \\
Turbidity (NTU) & 0.08 & 97.51 \\
COD (mg/L) & 81.8 & 43.90 \\
Total nitrogen (mg/L) & 0.53 & 33,75 \\
Particle size (nm) & $12.76-24.36$ & -- \\
\hline \hline
\end{tabular}

The optimum predicted results at the 95\% ClCE was calculated using Equation 4-16 and the observed experimental results for the response parameters are given in Table 4-13.

Table 4-13 - Summary and comparison of experimental and predicted optimal conditions for PMTE.

\begin{tabular}{ccccccc}
\hline \hline Method & Response & $\begin{array}{c}\text { Optimal } \\
\text { conditions }\end{array}$ & $\begin{array}{c}\text { Optimal } \\
\text { values }\end{array}$ & 95\% ClCE & $\begin{array}{c}\text { Confirmation } \\
\text { experiments }\end{array}$ & $\begin{array}{c}\% \\
\text { deviation }\end{array}$ \\
\hline \hline \multirow{2}{*}{ Multi - } & $\mu_{\mathrm{MRSN}}(\mathrm{dB})$ & & 19.78 & $18.54 \leq \mu_{\mathrm{MRSN}} \leq 21.08$ & 19.78 & 0.27 \\
response & $\bar{J}_{P}\left(\mathrm{~L} / \mathrm{m}^{2} \mathrm{~h}\right)$ & $\mathrm{A}^{*} \mathrm{~B}^{*}$ & 77.22 & $68.16 \leq \mathrm{JP} \leq 86.28$ & 81.15 & 4.84 \\
& $\mathrm{COD}(\%)$ & $\mathrm{C}^{*} \mathrm{D}^{*}$ & 45.69 & $43.45 \leq \mathrm{COD} \leq 47.92$ & 43.90 & 4.07 \\
& & & 6.24 & $5.39 \leq \mathrm{SFD} \leq 7.08$ & 6.01 & 3.75 \\
\hline \hline
\end{tabular}

- Significant at the $95 \%$ confidence interval.

Since the observed multi-response of the overall utility falls within the $95 \%$ confidence interval for the optimal range of the response variables, it is confirmed that the Taguchi method and utility concept can be used to predict the response for any parametric combination. 


\subsection{Conclusion}

In this study, the Taguchi method, utility concept and ANOVA analysis were used as statistical tools to investigate the effects and significance of four operating parameters and to optimize the UF process with respect to average permeate flux, COD rejection rate and cumulative flux decline.

ANOVA was used to determine the most significant factors affecting the response variables. From the percentage contribution, the order of importance of each factor in maximum $\bar{J}_{P}$ was TMP > MWCO > T > CFV; for maximum COD rejection rate it was MWCO > CFV > T > TMP; and to achieve the minimum SFD: MWCO > TMP > CFV > $\mathrm{T}$.

The optimum UF operating parameters, based on the Taguchi method and utility concept, were found at TMP (2.0 bar), CFV $(1.041 \mathrm{~m} / \mathrm{s})$, temperature $\left(15^{\circ} \mathrm{C}\right)$ and MWCO (100 kDa). Under these optimum conditions, $\bar{J}_{P}$, COD rejection rate and SFD resistance of $81.15 \mathrm{~L} / \mathrm{m}^{2} / \mathrm{h}, 43.90 \%$ and 6.01 (around $28.96 \%$ of $\overline{F D}$ ), respectively, were obtained and they were within of the predicted range at the $95 \%$ confidence interval.

Measurements of turbidity, COD and particle size in the permeate showed a significant decrease 3.21 to $0.0002 \mathrm{NTU}, 146 \mathrm{mg} / \mathrm{l}$ to $81.8 \mathrm{mg} / \mathrm{l}$ and $458-1281 \mathrm{~nm}$ to 12.71 $24.36 \mathrm{~nm}$, respectively, which confirms a substantial reduction in colloidal compounds. It can, therefore, be said that UF is suitable for removing dissolved and colloidal substances from wastewater effluents from recycled paperboard manufacturing.

The results demonstrate the validity of the approach of using Taguchi method and utility concept to obtain the optimal membrane conditions for the wastewater treatment using a reduced number of experiment.

Finally, this study could be used as a guideline for operating UF systems applied as a tertiary treatment for paperboard mill treated effluent s under optimal conditions. 


\subsection{References}

Alsaadi, N., Sheeraz, M.A., 2020. Design and optimization of bimorph energy harvester based on Taguchi and ANOVA approaches. Alexandria Engineering Journal 59, 117-127. https://doi.org/10.1016/j.aej.2019.12.016

APHA, 1998. Standard Methods for the Examination of Water and Wastewater, 20th Edition. American Public Health Association, Washington DC.

Barua, P.B., Kumar, P., Gaindhar, J.L., 1997. Optimal setting of process parameters for multi-characteristic products using Taguchi design and utility-conceptan approach. Proc ICAMIE, University of Roorkee (India) 839-842.

Beril Gönder, Z., Arayici, S., Barlas, H., 2011. Advanced treatment of pulp and paper mill wastewater by nanofiltration process: Effects of operating conditions on membrane fouling. Separation and Purification Technology 76, 292-302. https://doi.org/10.1016/j.seppur.2010.10.018

Bunn, D.W., 1982. Analysis for optimal decisions. John Wiley \& Sons, New York.

Cassano, A., Conidi, C., Drioli, E., 2011. Comparison of the performance of UF membranes in olive mill wastewaters treatment. Water Research 45, 3197-3204. https://doi.org/10.1016/j.watres.2011.03.041

Chen, C., Mao, S., Wang, J., Bao, J., Xu, H., Su, W., Dai, H., 2015. Application of Ultrafiltration in a Paper Mill: Process Water Reuse and Membrane Fouling Analysis. BioResources 2376-2391. https://doi.org/10.15376/biores.10.2.2376-2391

Cojocaru, C., Zakrzewska-Trznadel, G., 2007. Response surface modeling and optimization of copper removal from aqua solutions using polymer assisted ultrafiltration. Journal of Membrane Science 298, 56-70. https://doi.org/10.1016/j.memsci.2007.04.001

Ennil Köse, T., 2008. Agricultural residue anion exchanger for removal of dyestuff from wastewater using full factorial design. Desalination, European Desalination So ciety and Center for Research and Technology Hellas (CERTH), Sani Resort $22-25$ April 2007, Halkidiki, Greece 222, 323-330. https://doi.org/10.1016/j.desal.2007.01.156 
Ezzati, A., Gorouhi, E., Mohammadi, T., 2005. Separation of water in oil emulsions using microfiltration. Desalination, Desalination and the Environment 185, 371382. https://doi.org/10.1016/j.desal.2005.03.086

Gönder, Z.B., Arayici, S., Barlas, H., 2012. Treatment of Pulp and Paper Mill Wastewater Using Utrafiltration Process: Optimization of the Fouling and Rejections. Industrial \& Engineering Chemistry Research 51, 6184-6195. https://doi.org/10.1021/ie2024504

Gönder, Z.B., Kaya, Y., Vergili, I., Barlas, H., 2010. Optimization of filtration conditions for CIP wastewater treatment by nanofiltration process using Taguchi approach. Separation and Purification Technology 70, 265-273. https://doi.org/10.1016/.seppur.2009.10.001

Goyal, S., SINGH KANDRA, V., YADAV, P., 2016. EXPERIMENTAL STUDY OF TURNING OPERATION AND OPTIMIZATION OF MRR AND SURFACE ROUGHNESS USING TAGUCHI METHOD.

https://doi.org/10.6084/M9.FIGSHARE.3504332

Hesampour, M., Krzyzaniak, A., Nyström, M., 2008. The influence of different factors on the stability and ultrafiltration of emulsified oil in water. Journal of Membrane Science 325, 199-208. https://doi.org/10.1016/..memsci.2008.07.048

Idris, A., Ismail, A.F., Noordin, M.Y., Shilton, S.J., 2002. Optimization of cellulose acetate hollow fiber reverse osmosis membrane production using Taguchi method. Journal of Membrane Science 205, 223-237. https://doi.org/10.1016/S03767388(02)00116-3

Kaladhar, M., Subbaiah, K.V., Rao, Ch.S., Rao, K.N., 2011. Application of Taguchi approach and Utility Concept in solving the Multi-objective Problem when turning AISI 202 Austenitic Stainless Steel. Journal of Engineering Science and Technology Review 4, 55-61. https://doi.org/10.25103/jestr.041.08

Kamali, M., Khodaparast, Z., 2015. Review on recent developments on pulp and paper mill wastewater treatment. Ecotoxicology and Environmental Safety 114, 326-342. https://doi.org/10.1016/j.ecoenv.2014.05.005 
Kansal,H.K., Singh, S., Kumar, P., 2006. Performance parameters optimization (multicharacteristics) of powder mixed electric discharge machining (PMEDM) through Taguchi's method and utility concept. INDIAN J. ENG. MATER. SCI. 8.

Khaire, R.A., Gogate, P.R., 2020. Optimization of ultrafiltration of whey using Taguchi method for maximizing recovery of lactose. Separation and Purification Technology 248, 117063. https://doi.org/10.1016/j.seppur.2020.117063

Krawczyk, H., Oinonen, P., Jönsson, A.-S., 2013. Combined membrane filtration and enzymatic treatment for recovery of high molecular mass hemicelluloses from chemithermomechanical pulp process water. Chemical En gineering Journal 225, 292-299. https://doi.org/10.1016/j.cej.2013.03.089

Kumar, Y., Singh, H., 2014. Multi-response Optimization in Dry Turning Process Using Taguchi's Approach and Utility Concept. Procedia Materials Science, International Conference on Advances in Manufacturing and Materials Engineering, ICAMME 2014 5, 2142-2151. https://doi.org/10.1016/j.mspro.2014.07.417

Mänttäri, M., Nuortila-Jokinen, J., Nyström, M., 1997. Evaluation of nanofiltration membranes for filtration of paper mill total efflu ent. Filtration \& Separation 34, 275280. https://doi.org/10.1016/S0015-1882(97)84794-5

Mohammadi, T., Safavi, M.A., 2009. Application of Taguchi method in optimization of desalination by vacuum membrane distillation. Desalination 249, 83-89. https://doi.org/10.1016/j.desal.2009.01.017

Montgomery, D.C., 2008. Design and Analysis of Experiments. John Wiley \& Sons.

Mulder, J., 1996. Basic Principles of Membrane Technology, 2nd ed. Springer Netherlands.

Park, S., 1996. Robust Design and Analysis for Quality En gineering. Springer US.

Phadke, M.S., 1989. Quality engineering using robust design. Prentice Hall, Englewood Cliffs, N.J.

Pourjafar, S., Jahanshahi, M., Rahimpour, A., 2013. Optimization of TiO2 modified poly(vinyl alcohol) thin film composite nanofiltration membranes using Taguchi method. Desalination 315, 107-114. https://doi.org/10.1016/j.desal.2012.08.029 
Puro, L., Kallioinen, M., Mänttäri, M., Nyström, M., 2011. Evaluation of behavior and fouling potential of wood extractives in ultrafiltration of pulp and paper mill process water. Journal of Membrane Science 368, 150-158. https://doi.org/10.1016/j.memsci.2010.11.032

Puro, L., Tanninen, J., Nyström, M., 2002. Analyses of organic foulants in membranes fouled by pulp and paper mill effluent using solid-liquid extraction. Desalination 143, 1-9. https://doi.org/10.1016/S0011-9164(02)00215-1

Reyhani, A., Hemmati, M., 2014. Wastewater treatment by ultrafiltration system, considering the effects of operating conditions: experimental and modeling. Desalination and Water Treatment 52, 6282-6294. https://doi.org/10.1080/19443994.2013.815587

Reyhani, A., Sepehrinia, K., Shahabadi, S.M.S., Rekabdar, F., Gheshlaghi, A., 2015. Optimization of operating conditions in ultrafiltration process for produced water treatment via Taguchi methodology. Desalination and Water Treatment 54, 26692680. https://doi.org/10.1080/19443994.2014.904821

Rezvanpour, A., Roostaazad, R., Hesampour, M., Nyström, M., Ghotbi, C., 2009. Effective factors in the treatment of kerosene-water emulsion by using UF membranes. Journal of Hazardous Materials 161, 1216-1224. https://doi.org/10.1016/j.jhazmat.2008.04.074

Ross, P.J., 1996. Taguchi Techniques for Quality Engineering: Loss Function, Orthogonal Experiments, Parameter and Tolerance Design. McGraw Hill Professional.

Roy, R.K., 1990. A Primer on the Taguchi Method. Society of Manufacturing Engineers.

Saaty, T.L., 1980. Analytic Hierarchy Process. McGraw Hill Higher Education, New York; London.

Salahi, A., Abbasi, M., Mohammadi, T., 2010. Permeate flux decline during UF of oily wastewater: Experimental and modeling. Desalination 251, 153-160. https://doi.org/10.1016/j.desal.2009.08.006 
Seyed Shahabadi, S.M., Reyhani, A., 2014. Optimization of operating conditions in ultrafiltration process for produced water treatment via the full factorial design methodology. Separation and Purification Technology 132, 50-61. https://doi.org/10.1016/j.seppur.2014.04.051

Song, L., 1998. Flux decline in crossflow microfiltration and ultrafiltration: mechanisms and modeling of membrane fouling. Journal of Membrane Science 139, 183-200. https://doi.org/10.1016/S0376-7388(97)00263-9

Sousa, M.R.S., Lora-Garcia, J., López-Pérez, M.-F., 2018. Modelling approach to an ultrafiltration process for the removal of dissolved and colloidal substances from treated wastewater for reuse in recycled paper manufacturing. Journal of Water Process Engineering 21, 96-106. https://doi.org/10.1016/j.jwpe.2017.11.017

Wu, Y., Zhang, Z., He, P., Ren, H., Wei, N., Zhang, F., Cheng, H., Wang, Q., 2019. Membrane fouling in a hybrid process of enhanced coagulation at high coagulant dosage and cross-flow ultrafiltration for deinking wastewater tertiary treatment. Journal of Cleaner Production 230, 1027-1035. https://doi.org/10.1016/j.jclepro.2019.05.139

Xu, J., Chang, C.-Y., Gao, C., 2010. Performance of a ceramic ultrafiltration membrane system in pretreatment to seawater desalination. Separation and Purification Technology 75, 165-173. https://doi.org/10.1016/j.seppur.2010.07.020 
5 CHAPTER: MODELLING APPROACH TO AN ULTRAFILTRATION PROCESS FOR THE REMOVAL OF DISSOLVED AND COLLOIDAL SUBSTANCES FROM TREATED EFFLUENT FOR REUSE IN RECYCLED PAPER MANUFACTURING 


\subsection{Abstract}

In this chapter, cross-flow UF is used to remove DCS from a secondary clarifier effluent from WWTP in a papermaking factory. The approach has been to examine and model the decline in permeate flux resulting from membrane fouling. UF experiments were carried out in a laboratory-scale plant using a $10 \mathrm{kDa}$ polyethersulfone (PES) UF membrane in a flat sheet module with an active area of $154.8 \mathrm{~cm}^{2}$. The transmembrane pressure (TMP) (1-3 bar) and crossflow rate (1.5-4.5 L/min) were varied during the experiments, at constant temperature $\left(22 \pm 0.5^{\circ} \mathrm{C}\right)$. Experimental results from UF tests were expressed in terms of permeate flux (Jp) as a function of time to check modified Hermia's models adapted to crossflow filtration. The parameters of these models were theoretically estimated. The predicted results were compared with experimental data with a high goodness of fit. The results showed that the phenomenon controlling fouling, under most of the conditions tested, was intermediate blocking $\left(R^{2}>0.96\right)$. Measurements of particle size distribution and zeta potential near the isoelectric point, showed a substantial reduction in colloidal compounds. Additionally, given that COD was removed down to $110 \mathrm{mg} / \mathrm{L}$, it could be said that UF is suitable for producing water that can be reused in different papermaking processes.

\subsection{Introduction}

Ultrafiltration can be used as an advanced tertiary treatment to remove suspended solids and DCS during the treatment of paper industry effluent. However, membrane fouling limits the application and use of UF (Xu et al., 2019) and, currently, this treatment technology can only be used to filter paper mill effluent that has been pretreated and meets discharge standards (Puro et al., 2011a).

DCS might play a number of different roles in membrane fouling. Colloidal substances larger than the pores cannotpass through the membrane and they will be deposited on the membrane surface blocking the pores. Dissolved substances that are smaller than the membrane pore-size are adsorbed within the pores and/or deposited within the membrane, shrinking the pore diameter and increasing membrane resistance. In addition, once pores are blocked, other DCS can form a cake on top of the membrane, adding additional resistance via another porous layer covering the membrane (Carroll et al., 2000; Sanaei and Cummings, 2017). 
According to research performed by Chen et al. (2015a), reversible membrane fouling during ultrafiltration accounted for $85.52 \%$ of total fouling. It primarily originated from retention aids, drainage aids, polyacrylamide and wet strength resins. While irreversible adsorptive fouling accounted for $14.48 \%$ and mostly came from sizing agents, coating chemicals (oxidants for polyester or resin and polyester or resin surface sizing agents) and other sources. Moreover, the presence of dissolved multivalent metal ions, especially $\mathrm{Ca}^{2+}$, accelerated membrane fouling (Puro et al., 2002b).

The empirical and theoretical mathematical models used to describe permeate flux decline over time for a UF process and to describe membrane fouling mechan isms can be found in the literature. Some of the most well known are described by Hermia. (1982), Song. (1998b), (Ho and Zydney, 2000), Bhattacharjee et al. (2007), Vela et al. (2008), Lin et al. (2008) and Corbatón-Báguena et al. (2015). In general, empirical models are very accurate because they describe experimental results by fitting a mathematical equation to the data obtained without considering any theoretical parameters. Despite this, they cannot explain the fouling mechanisms involved in membrane filtration. On the other hand, theoretical models can help in the understanding of fouling phenomena, although they are less accurate if experimental data are not used to estimate some of their parameters Lin et al. (2008).

The importance and the novelty of the current work comes from the need to advance understanding of the behaviour of the UF process and its application for the removal of colloidal organic matter from treated wastewater (effluentarising from the secondary biological reactor) in paper mills. Focused especially on the effects of dissolved and colloidal substances on membrane fouling mechanisms. The study also included the analysis of a dynamic model for permeate flux decline and resistance due to membrane fouling (fouling resistance). The mathematical modelling used to verify the experimental results was based on a pore blocking model for tangential filtration adapted from Hermia's dead-end filtration laws (Hermia, 1982; Ohanessian et al., 2020; Silva et al., 2020; Vela et al., 2008) and the resistance-in-series model at constant pressure (Song, 1998). 


\subsection{Materials and methods}

\subsubsection{Effluent sample used as feed solution}

The PMTE used as feed solution and average physical and chemical composition are described in Section 3.1.

\subsubsection{Membrane fouling experiments}

To identify the fouling mechanism, the membrane was contaminated using a sample of an effluent previously treated by conventional filtration (Section 3.4), with the following parameters: TSS 0.012 g/L, tu rbidity 39.5 NTU, COD 252 mg/L, DOC 130 $\mathrm{mg} / \mathrm{L}$ and particle size distribution $158.9 \mathrm{~nm}-1642 \mathrm{~nm}$.

Membrane fouling was analysed in two stages. The first was based on the pore blocking model (Section 2.5.1), which is responsible for the initial permeate flux decline, and the second was based on the modelling of cake formation (Section 2.5.3), which is the cause of long-term gradual flux decline. The data predicted by the model were compared with the experimental results obtained in the membrane fouling experiments as shown in results and discussion (Section 5.4).

\subsubsection{Fouling models for cross-flow filtration}

\subsubsection{Pore blocking description}

Hermia. (1982) developed four empirical models for constant pressure in dead-end filtration process, that correspond to four basic types of mechanisms for membrane fouling: complete blocking, intermediate blocking, standard blocking and cake layer formation. Therefore, some studies have been carried out to adapted pore blocking models to crossflow filtration in order to predict permeate flux decline (Brião and Tavares, 2012; de Barros et al., 2003; Field et al., 1995; Jacob et al., 1998; Vincent Vela et al., 2009). The general form of the equation for the four fouling mechanisms in cross-flow filtration is shown in the following equation:

$$
-\frac{d J_{p}}{d t}=k\left(J_{p}-J_{s s}\right) \cdot J_{p}{ }^{2-n}
$$

Equation 5-1

where, the terms $J_{0}$ is the initial permeate flux $(\mathrm{m} / \mathrm{s})$ calculated at time $\mathrm{t}=0$; $\mathrm{t}$ is the filtration time (s); $J_{s s}$ can be considered to be steady-state permeate flux $(\mathrm{m} / \mathrm{s}) ; \mathrm{k}$ (depends of the pore blocking mechanism) and $\mathrm{n}$ (dimensionless) are a phenomenological coefficientand a general index, respectively, both depending on the 
fouling mechanism, the TMP, the dynamic viscosity of the permeate, the blocked area per unitof permeate flux and the membrane resistance $(\mathrm{Rm})$ (Field et al., 1995; Vincent Vela et al., 2009).

The integration of Equation 5-1 gave the distinct pore-blocking mechanisms as a function of the index $n$. The equations relating the permeate flux vs. filtration time for the individual models are given below in Table 5-1.

Table 5-1 - Fouling mechanism for constant flow rate in cross-flow UF (Field et al., 1995).

\begin{tabular}{|c|c|c|c|c|}
\hline $\begin{array}{c}\text { Fouling } \\
\text { mechanism }\end{array}$ & $m$ & Fouling concept & Fouling models & Eq. \\
\hline $\begin{array}{l}\text { Complete } \\
\text { blocking }\end{array}$ & 2 & Pore sealing & $J_{p}=J_{s S}+\left(J_{0}-J_{s S}\right) \cdot e^{-K_{C} \cdot t}$ & $5-2$ \\
\hline $\begin{array}{l}\text { Intermediate } \\
\text { blocking }\end{array}$ & 1 & $\begin{array}{c}\text { Pore sealing and } \\
\text { membrane deposition }\end{array}$ & $J_{p}=\frac{J_{0} \cdot J_{S S} \cdot e^{K_{i} \cdot J_{S S} \cdot t}}{J_{S S}+J_{0}\left(e^{K_{i} \cdot J_{S S} \cdot t}-1\right)}$ & $5-3$ \\
\hline $\begin{array}{l}\text { Standard } \\
\text { blocking }\end{array}$ & 1.5 & Pore walls restricted & $J_{p}=\frac{J_{0}}{\left(1+J_{0}^{1 / 2} \cdot K_{s} \cdot t\right)^{2}}$ & $5-4$ \\
\hline $\begin{array}{c}\text { Cake } \\
\text { formation }\end{array}$ & 0 & Cake layers on surface & $\begin{aligned} J_{S S}^{2} \cdot K_{g l} \cdot t=\ln & {\left[\left(\frac{J_{p}}{J_{0}} \cdot \frac{J_{0}-J_{s S}}{J_{p}-J_{s S}}\right)\right] } \\
& -J_{s S}\left(\frac{1}{J_{p}}-\frac{1}{J_{0}}\right)\end{aligned}$ & $5-5$ \\
\hline
\end{tabular}

The predicted permeate flux was calculated after optimization of fouling resistance coefficients $\left(K_{C b}, K_{i b}, K_{s b}\right.$ and $\left.K_{c l}\right)$.

The algorithm used to optimize $K$ parametrs is schematically represented in Figure 5-1. 


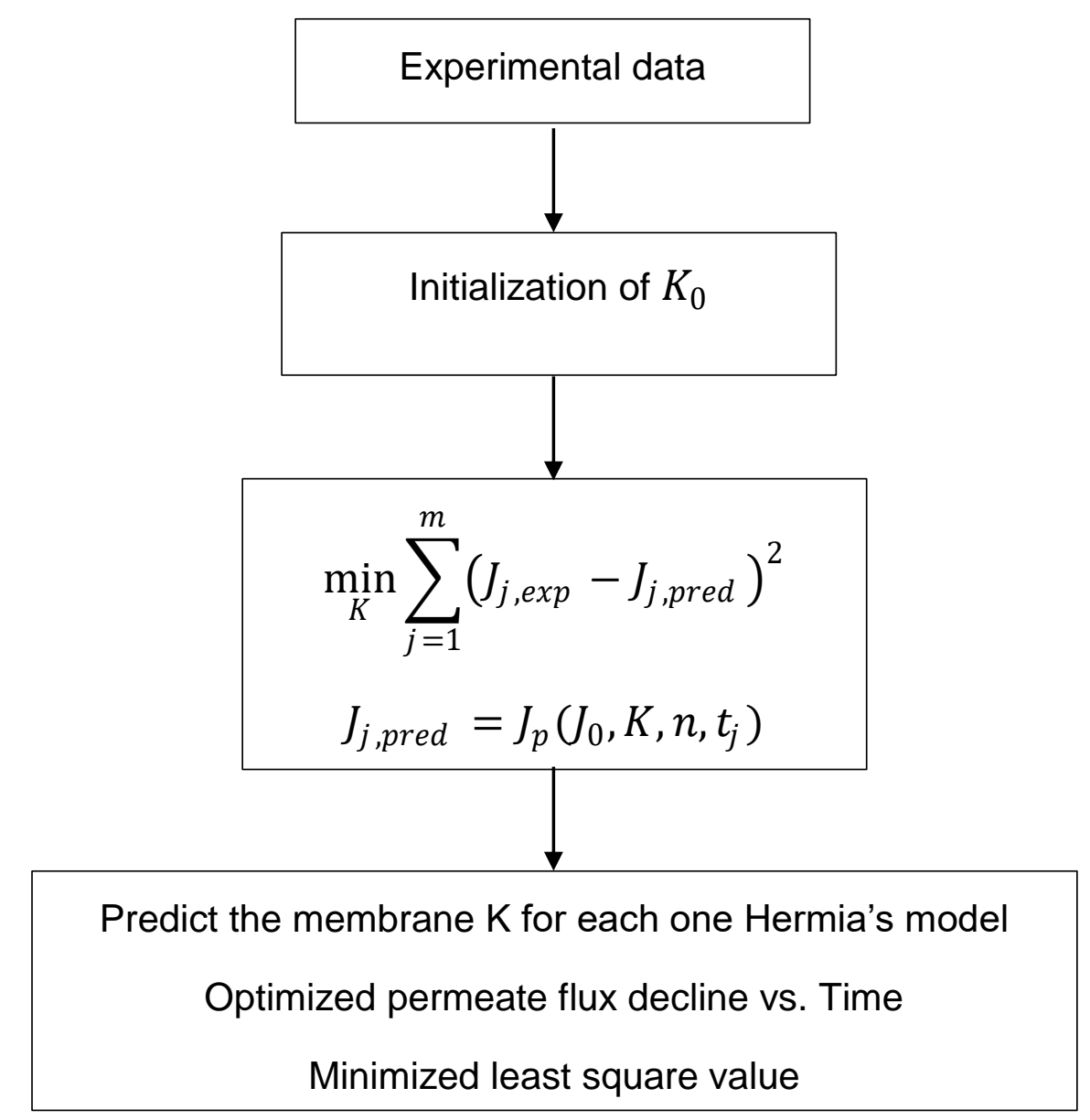

Figure 5-1- Algorithm for the parameter K optimization.

5.3.3.2 Determination of the sum of squared deviations and average relative error

The non-linear regression analysis was employed in order to minimize the overall difference between experimental and predicted permeate flux obtained during UF PMTE.

The success of fitting were evaluated in terms of the standard error of the estimate (SEE) and regression coefficient $\left(R^{2}\right)$. They can be calculated by the Equation 5-6 and Equation 5-7:

$$
S E E=\min _{K} \sqrt{\frac{1}{m-2} \sum_{j=1}^{m}\left(J_{j, \text { exp }}-J_{j, \text { pred }}\right)^{2}}
$$




$$
R^{2}=1-\min _{K} \sum_{j=1}^{m} \frac{\left(J_{j, \exp }-J_{j, p r e d}\right)^{2}}{\left(J_{j, \exp }-\bar{J}_{\exp }\right)^{2}}
$$

where:

$J_{\text {exp }}$ and $J_{\text {pred }}$ are, respectively, experimental permeate flux and predicted permeate flux, $m$ is the data points at filtration time.

\subsection{Constant-pressure filtration and cake formation}

The resistance-in-series model is based on the fact that flux decline is comprised of different factors, including pore adsorption, pore blocking, cake formation, and concentration polarisation (Mulder, 1996). In this model, permeate flux through a membrane is proportional to the applied pressure and inversely proportional to the resistance caused by the cake layer and the membrane and governed by the general filtration equation (Darcy's law) given as:

$$
J_{p}=\frac{\Delta P-\Delta P_{c}}{\mu \cdot\left[R_{m}+R_{c}(t)\right]}
$$

Equation 5-8

The hydraulic resistance due to the cake formation $R_{c}$ can be considered as the sum of three deferent factors: $R_{p l}$, the polarisation layer resistance; $R_{a d}$, the fouling resistance caused by particle adsorption; and $R_{f}$, the fouling resistance, which can be divided into irreversible and reversible.

As described in section 2.5.3 the Equation 2-34 can be integrated and solved for $J_{p}$ to give an expression to predict the flux decline, the cake resistance and the growth in cake layer as a function of time (t) (see equations below):

$$
\begin{aligned}
& J_{p}(t)=\frac{\left(\Delta P-\Delta P_{c}\right)}{R_{b m}}\left(1+\frac{2 r_{c}\left(\Delta P-\Delta P_{c}\right)}{R_{b m}{ }^{2}} \frac{C_{0}}{C_{g}} t\right)^{-1 / 2} \\
& R_{c}(t)=R_{b m}\left[\left(1+\frac{2 r_{c}\left(\Delta P-\Delta P_{c}\right)}{R_{b m}{ }^{2}} \frac{C_{0}}{C_{g}} t\right)^{1 / 2}-1\right]
\end{aligned}
$$

Equation 5-9

Equation 5-10

and,

$$
\delta(t)=\frac{R_{b m}}{r_{c}}\left[\left(1+\frac{2 r_{c}\left(\Delta P-\Delta P_{c}\right)}{R_{b m}{ }^{2}} \frac{C_{0}}{C_{g}} t\right)^{-1 / 2}-1\right]
$$




\subsection{Results and discussion}

\subsubsection{Membrane characterisation}

The experimental data for the pure water permeate through the membrane (Membrane characterisation section 3.5.2) were used to evaluate the membrane hydraulic resistance $\left(R_{m}\right)$ according to Darcy's law:

$$
J_{p}=\frac{\Delta P}{\mu \cdot R_{m}}
$$

The values obtained for membrane resistance as a function of the applied transmembrane pressure are shown in Figure 5-2.

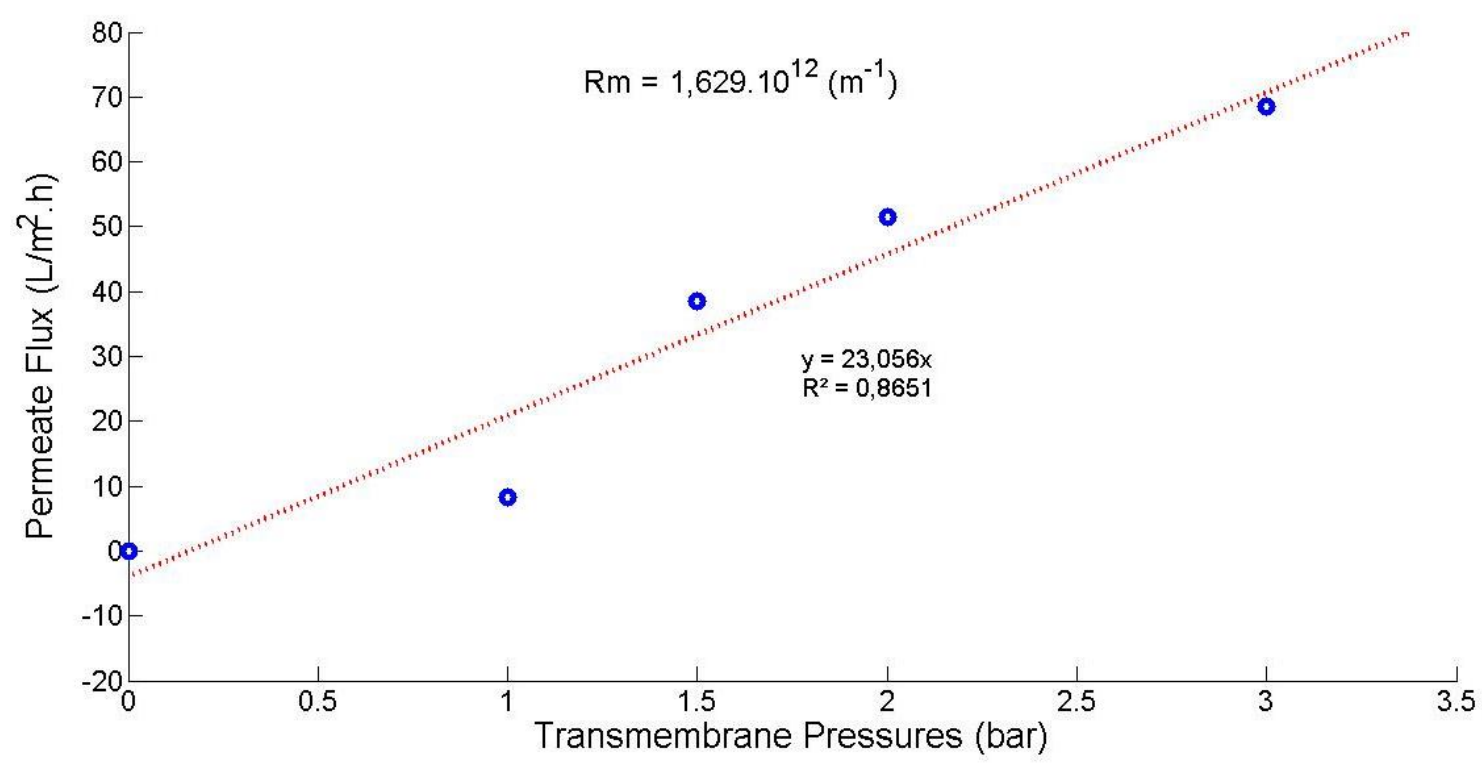

Figure 5-2 - Pure water permeate flux vs. applied pressure. $\operatorname{TMPs}(1.0,1.5,2.0$ and 3.0 bar) at $22{ }^{\circ} \mathrm{C}$, crossflow rate of $4.5 \mathrm{~L} / \mathrm{min}$ and operation time $2 \mathrm{~h}$. The value obtained for the $R_{m}$ for the flat sheet $10 \mathrm{kDa}$ PES membrane was $1.629 \times 10^{12}\left(\mathrm{~m}^{-1}\right)$.

5.4.2 Physical and chemical aspects of PMTE after the ultrafiltration process It is interesting to observe the performance of the separation by ultrafiltration from a physical and chemical point of view before evaluating the modelling of membrane fouling and pore blocking mechanisms. The results obtained for the physical-chemical parameters are given in Table 5-2. 
Table 5-2 - Physical-chemical parameters of the effluent treated by conversional filtration and ultrafiltration separation.

\begin{tabular}{c||c||c}
\hline \hline Parameter & $\begin{array}{c}\text { Conventional } \\
\text { filtration by }(5 \mu \mathrm{m})\end{array}$ & $\begin{array}{c}\text { Ultrafiltration } \\
\text { sepration }\end{array}$ \\
\hline \hline Turbidity (NTU) & 39.5 & 0.2 \\
COD $(\mathrm{mg} / \mathrm{L})$ & 252 & 110 \\
TSS $(\mathrm{g} / \mathrm{L})$ & 0.012 & 0.0001 \\
SS $(\mathrm{ml} / \mathrm{L})$ & 0 & 0 \\
DOC $(\mathrm{mg} / \mathrm{L})$ & 130 & 110 \\
Conductivity $(\mathrm{ms} / \mathrm{cm})$ & 3.56 & 3.06 \\
$\mathrm{pH}$ & 7.8 & 8.5 \\
Total nitrogen $(\mathrm{mg} / \mathrm{L})$ & 1.7 & 1.1 \\
Temperature $\left({ }^{\circ} \mathrm{C}\right)$ & 24.0 & 24.0 \\
Particle size $(\mathrm{nm})$ & $158.9-1642$ & $99.10-334.2$ \\
\hline \hline
\end{tabular}

Ultrafiltration removed $54.36 \%$ of COD from the treated wastewater (effluent from WWTP) as compared to that of the secondary biological reactor, indicating that a considerable portion of the organic matter is colloidal. Removal of nitrogen could be observed, with a reduction from $1.7 \mathrm{mg} / \mathrm{L}$ to $1.1 \mathrm{mg} / \mathrm{L}$ (64\% removal). Suspended solids were almost completely removed by the conventional filtration (filter with a pore size of $5 \mathrm{~mm}$ ) and UF, with a total decrease of $99 \%$.

The turbidity was reduced by $99.5 \%$ after ultrafiltration treatment and the particle size distribution in the secondary biological reactor effluent greatly decreased from the range 188.7 - $5499.03 \mathrm{~nm}$ to 99.10 - $334.2 \mathrm{~nm}$ following UF. Both parameters demonstrated the effective removal of macromolecular colloids from recycled paper and cardboard process water.

The concentration of dissolved organic carbon before and after ultrafiltration is practically the same, less than $15 \%$ was removed by UF, results that were expected. Conductivity was around $3.06 \mathrm{mS} / \mathrm{cm}$ after UF treatment, a less than $14 \%$ decrease; a possible explanation for this effect may be that the UF process cannot remove electrolyte complexes of the dissolved and colloidal substances.

\subsubsection{Pore Blocking Mechanism}

To identify the mechanism of pore blocking during PMTE ultrafiltration, it was adopted the comparative study between experimental permeate flux and different mathematical 
models for flux decline, as shown in other studies (Corbatón-Báguena et al., 2017; de Barros et al., 2003; Field et al., 1995; Gimenes et al., 2014; Vela et al., 2008).

The flux decline curves were analysed using blocking laws adapted to cross flow filtration Equation 5-1 (Hermia, 1982) to determine the fouling mechanism. The parameter $k$ was estimated and fitted to four blocking models according the nonlinear regression optimization procedure implemented in MATLAB ${ }^{\circledR}$ software (Appendix $B$ ). The Figure 5-3 -Figure 5-5 present the fitting of the experimental UF data to Hermia blocking model, at the pressures indicated below.
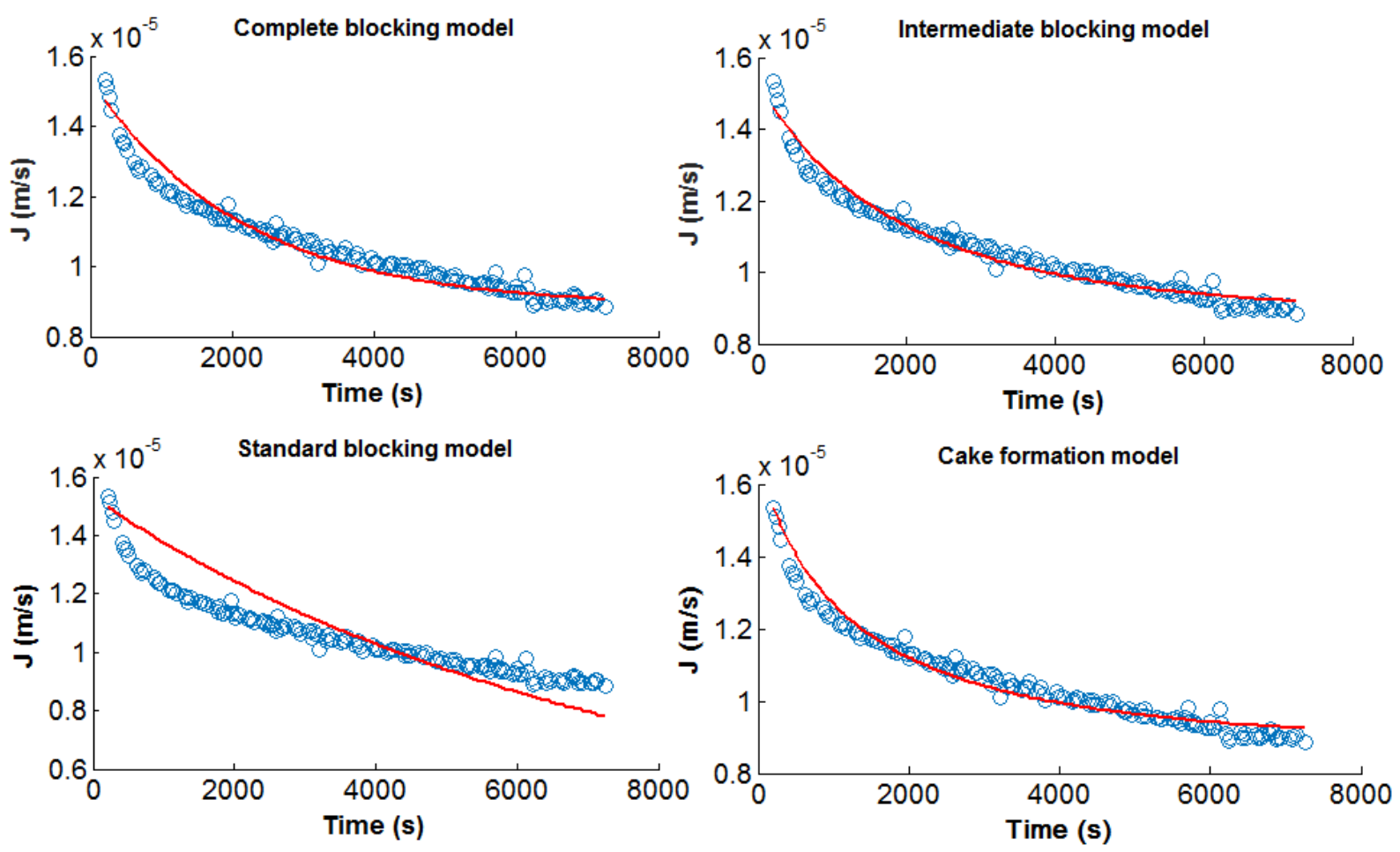

Figure 5-3 - Hermia's pore blocking models fitting for recycled paper wastewater 10 kDa PES membrane filtration experiments, at 3 bar. 

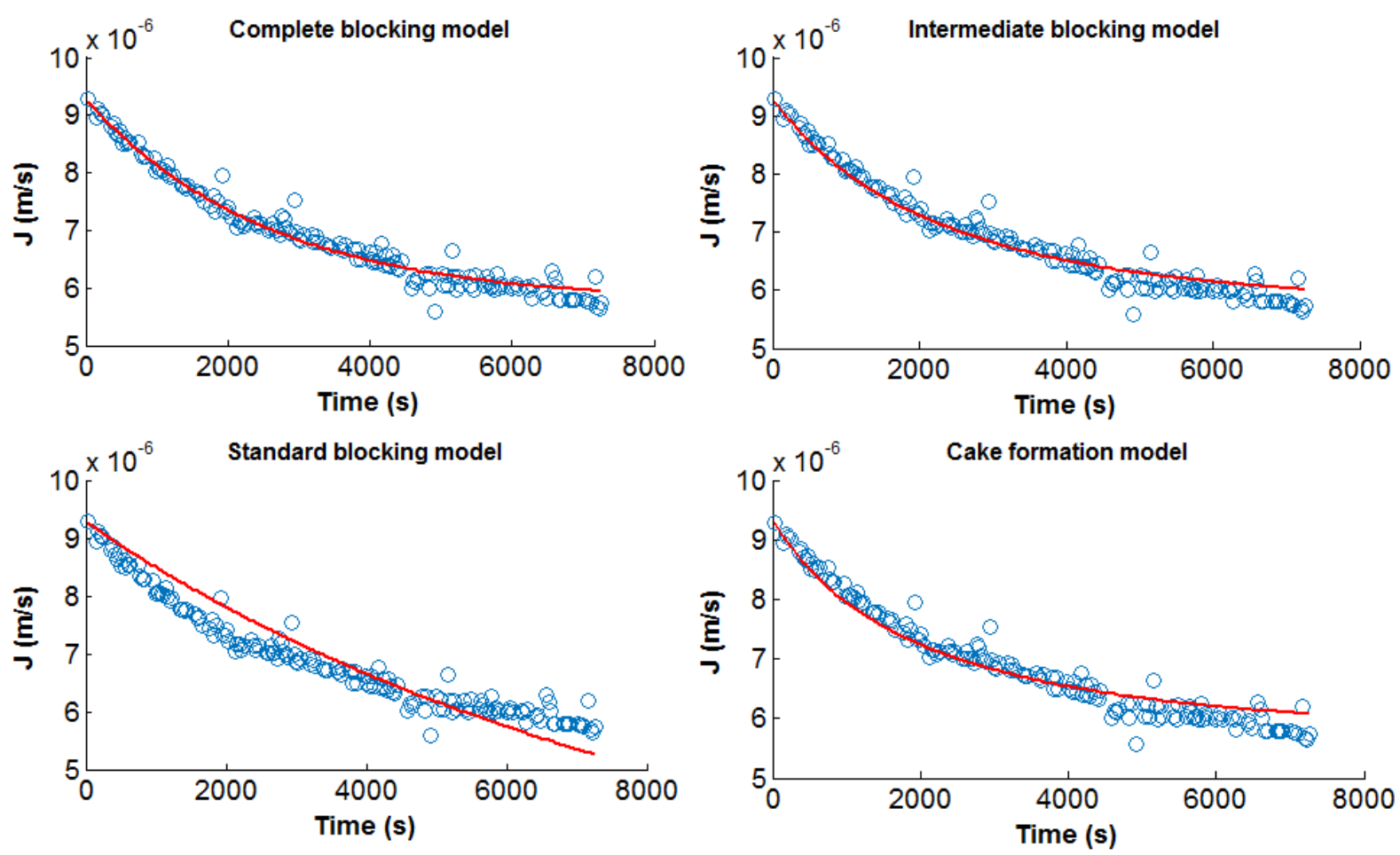

Figure 5-4 - Hermia's pore blocking models fitting for recycled paper wastewater $10 \mathrm{kDa}$

PES membrane filtration experiments, at 2 bar.
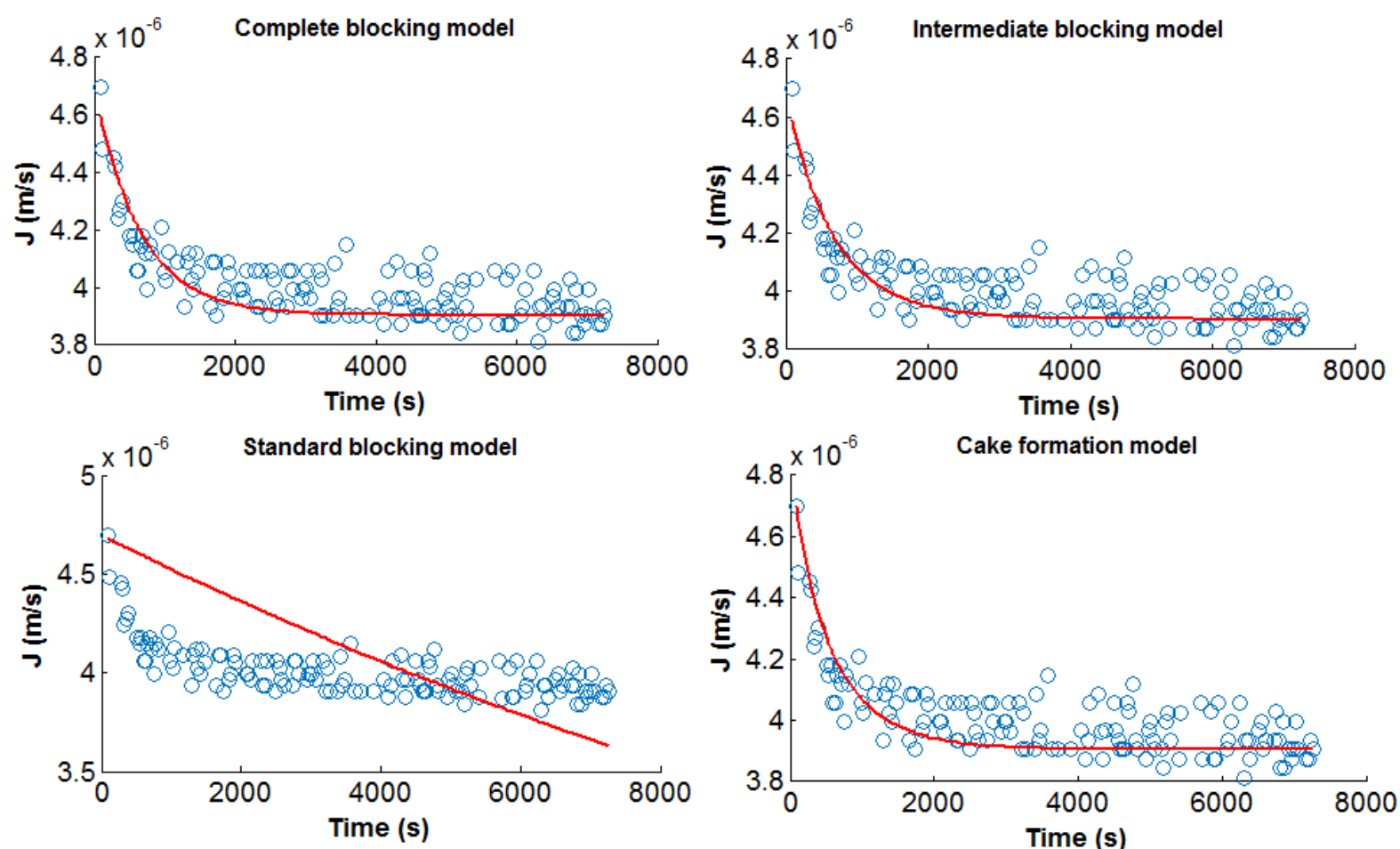

Figure 5-5 -Hermia's pore blocking models fitting for recycled paper wastewater $10 \mathrm{kDa}$ PES membrane filtration experiments, at 1 bar.

The quality of the fitting models for each operating condition tested were examined using the standard error of the estimate (SEE) and regression coefficient $\left(R^{2}\right)$, between 
the numerical predictions and experimental data. The results of the fitting accuracy for all pore-blocking models tested (adapted to crossflow UF) are showed in Table 5-3.

Note that the SEE and $\mathrm{R}^{2}$ values for each fitted pore-blocking model vary depending on the operating conditions used (TMP). Then shows that at 3 bar the best fitting model, and thus the lowest SEE and highest $\mathrm{R}^{2}$ value, was for the intermediate blocking model with SEE and average $R^{2}$ values of $2.48 \times 10^{-7}(\mathrm{~m} / \mathrm{s})$ and 0.967 , respectively. At 2 bar, a good fit was noted for the approximation between complete blocking ( $\mathrm{SEE}=1.55 \times 10^{-7}(\mathrm{~m} / \mathrm{s})$ and $\left.\mathrm{R}^{2}=0.972\right)$ and intermediate blocking ( $\mathrm{SEE}=1.79$ $\times 10^{-7}(\mathrm{~m} / \mathrm{s})$ and $\left.R^{2}=0.963\right)$. The differences between the experimental data and the fitted model were the highestfor a low transmembrane pressure (e.g. 1 bar), achieving values down to 0.585 for all pore blocking mechanism as observed in Figure 5-5 and Table 5-3. It is important to note that the membrane does not have a homogeneous pore size distribution, thus fouling does not occur in the same way and at the same rate at every pore. 
Table 5-3 - Pore blocking $R^{2}$, fitting of Hermia's models. Values for recycled paper wastewater 10 kDa MWCO PES membrane, ultrafiltration experiments.

\begin{tabular}{|c|c|c|c|c|c|c|c|c|c|c|c|c|}
\hline \multirow{2}{*}{$\begin{array}{l}\text { TMP } \\
(\mathrm{MPa})\end{array}$} & \multicolumn{3}{|c|}{$\begin{array}{l}\text { Complete } \\
\text { blocking }\end{array}$} & \multicolumn{3}{|c|}{$\begin{array}{c}\text { Intermediate } \\
\text { blocking }\end{array}$} & \multicolumn{3}{|c|}{$\begin{array}{l}\text { Standard } \\
\text { blocking }\end{array}$} & \multicolumn{3}{|c|}{$\begin{array}{c}\text { Cake } \\
\text { formation }\end{array}$} \\
\hline & $\begin{array}{c}\text { SEE } \\
\left(\mathrm{m} \cdot \mathrm{s}^{-1}\right) \cdot 10^{7}\end{array}$ & $\mathrm{R}^{2}$ & $\begin{array}{c}\mathrm{K}_{\mathrm{c}} \\
\left(\mathrm{m}^{-1}\right) \cdot 10^{4}\end{array}$ & $\begin{array}{c}\text { SEE } \\
\left(\mathrm{m} \cdot \mathrm{s}^{-1}\right) \cdot 10^{7}\end{array}$ & $\mathrm{R}^{2}$ & $\begin{array}{c}\mathrm{K}_{\mathrm{i}} \\
\left(\mathrm{m}^{-1}\right)\end{array}$ & $\begin{array}{c}\text { SEE } \\
\left(\mathrm{m} . \mathrm{s}^{-1}\right) \cdot 10^{7}\end{array}$ & $\mathrm{R}^{2}$ & $\begin{array}{c}\mathrm{K}_{\mathrm{s}} \\
\left(\mathrm{m}^{-1 / 2} \cdot \mathrm{s}^{-1 / 2}\right)\end{array}$ & $\begin{array}{c}\text { SEE } \\
\left(\mathrm{m} \cdot \mathrm{s}^{-1}\right) \cdot 10^{7}\end{array}$ & $\mathrm{R}^{2}$ & $\begin{array}{c}\mathrm{K}_{\mathrm{g}} \\
\left(\mathrm{s} / \mathrm{m}^{2}\right) \cdot 10^{-6}\end{array}$ \\
\hline 3.0 & 3.158 & 0.946 & 4.637 & 2.480 & 0.967 & 37.776 & 8.578 & 0.606 & 0.0282 & 2.779 & 0.958 & 3.468 \\
\hline 2.0 & 1.550 & 0.972 & 3.914 & 1.793 & 0.963 & 50.778 & 3.371 & 0.872 & 0.0297 & 2.117 & 0.948 & 6.706 \\
\hline 1.0 & 0.862 & 0.568 & 15.320 & 0.846 & 0.583 & 345.67 & 2.76 & 0.124 & 0.0175 & 0.868 & 0.561 & 93.880 \\
\hline
\end{tabular}


Therefore, it can be concluded that for all cases the best fit to the experimental data corresponds to the intermediate and complete blocking model followed by the cake layer formation. However, for all operating condition tested (TMP) standard poreblocking did not fitted to the experimental data very well, it may be due to this model considers that solute particles are smaller that the membrane pore size (Figure 2-14 (c) ) and therefore deposit on the pore walls of the membrane, that is to say $d_{\text {particle }} \ll$ $d_{\text {pore }}$. In addition, the materials accumulated on a membrane surface that cannotbe removed by cleaning procedures (backwash) and/or cross-flow can lead to irreversible fouling, resulting in permanent permeability loss and membrane fouling (Peng et al., 2004)

Through the pore blocking models analysis it is also possible to suggest that the colloidal matter is the main cause of the fouling as it forms a cake on the membrane. This is related to the permeability of the cake structure and gel layer formed by large colloids (i.e. $>220 \mathrm{~nm}$ ). In addition, dissolved substances are causing fouling by precipitating on the membrane surface and becoming adsorbed within the membrane pore space (dissolved material $<220 \mathrm{~nm}$ ). It is worth mentioning that the particle size distribution in the feed stream after the conventional filtration was between 1642 $158.9 \mathrm{~nm}$, which suggests the presence of both dissolved and colloidal matter.

The composition of DCS is very complex, most of this is organic matter, which comes from soluble carbohydrates, macromolecule such as lignin, anionic polymers, hetero polysaccharides such as hemicelluloses, lipophilic extracts of wood and papermaking additives (Liang et al., 2011). It is important to mention that in this study measures were not taken to characterise the foulant components responsible for membrane fouling, which will be undertaken in future work.

\subsubsection{Estimation of the Pore Blocking resistance $\left(R_{p b}\right)$}

The fouling resistance concerning to the predicted permeate flux by pore blocking models, can be expressed by the Equation 5-13:

$$
R_{p b}=\frac{T M P}{\mu . J_{p b(\text { pred })}}-R_{m}
$$

where,

$R_{p b}$ is the theoretical resistance due to pore blocking mechanism; and 
$J_{p b(\text { pred })}$ is the permeate flux predicted by pore blocking models ( 5-2 -

$5-5)$.

The membrane was fouled at different TMP of 1.0, 2.0 and 3.0 bar, to investigate the influence of TMP on pore blocking resistance. The following operating conditions were adopted in the test: $10 \mathrm{kDa}$ PES membrane, at $22^{\circ} \mathrm{C}$ and $4.5 \mathrm{l} / \mathrm{min}$. The fouling resistance estimation $\left(R_{p b}\right)$ are presented in Figure 56 . and Figure 5-7.

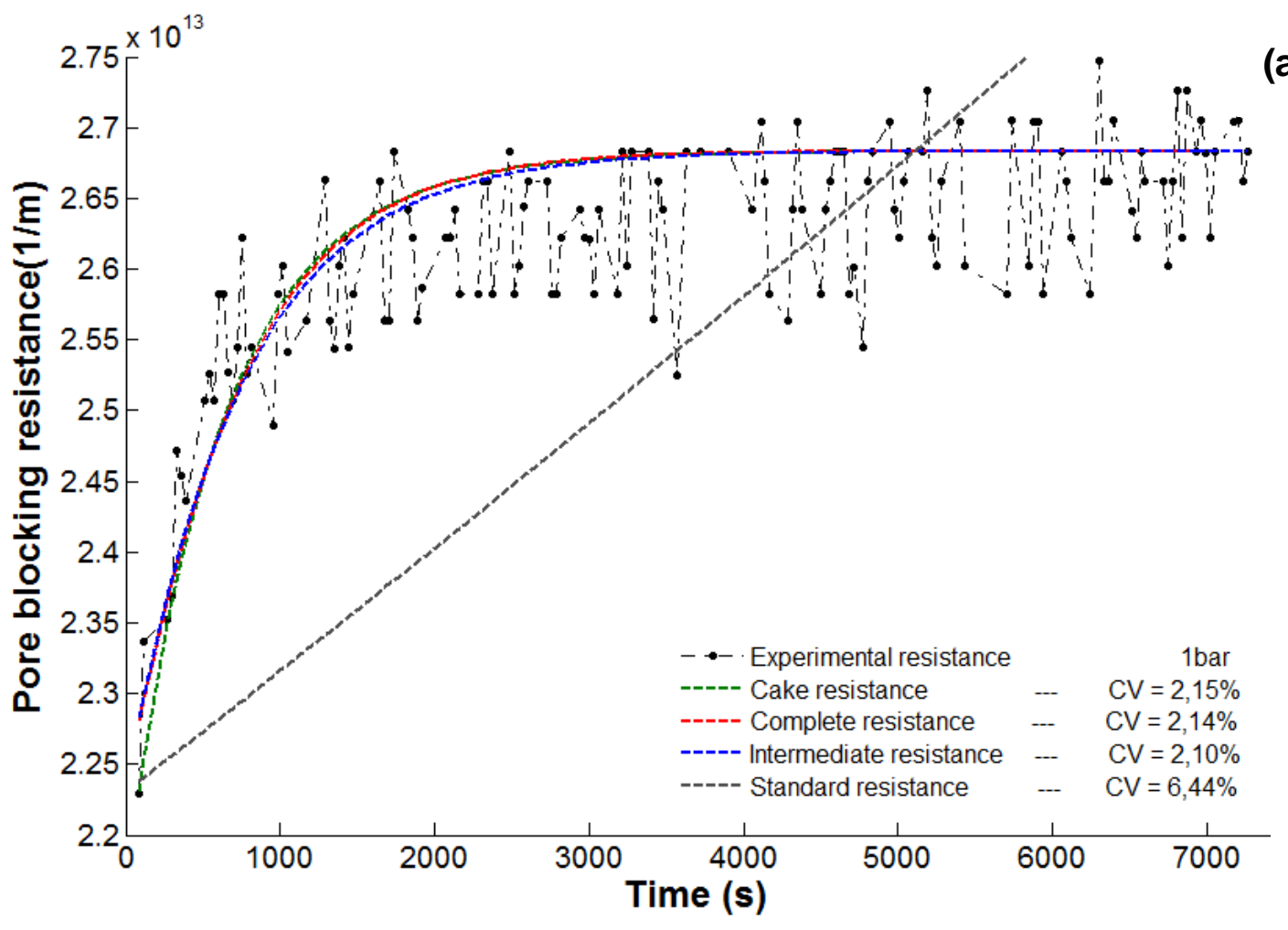



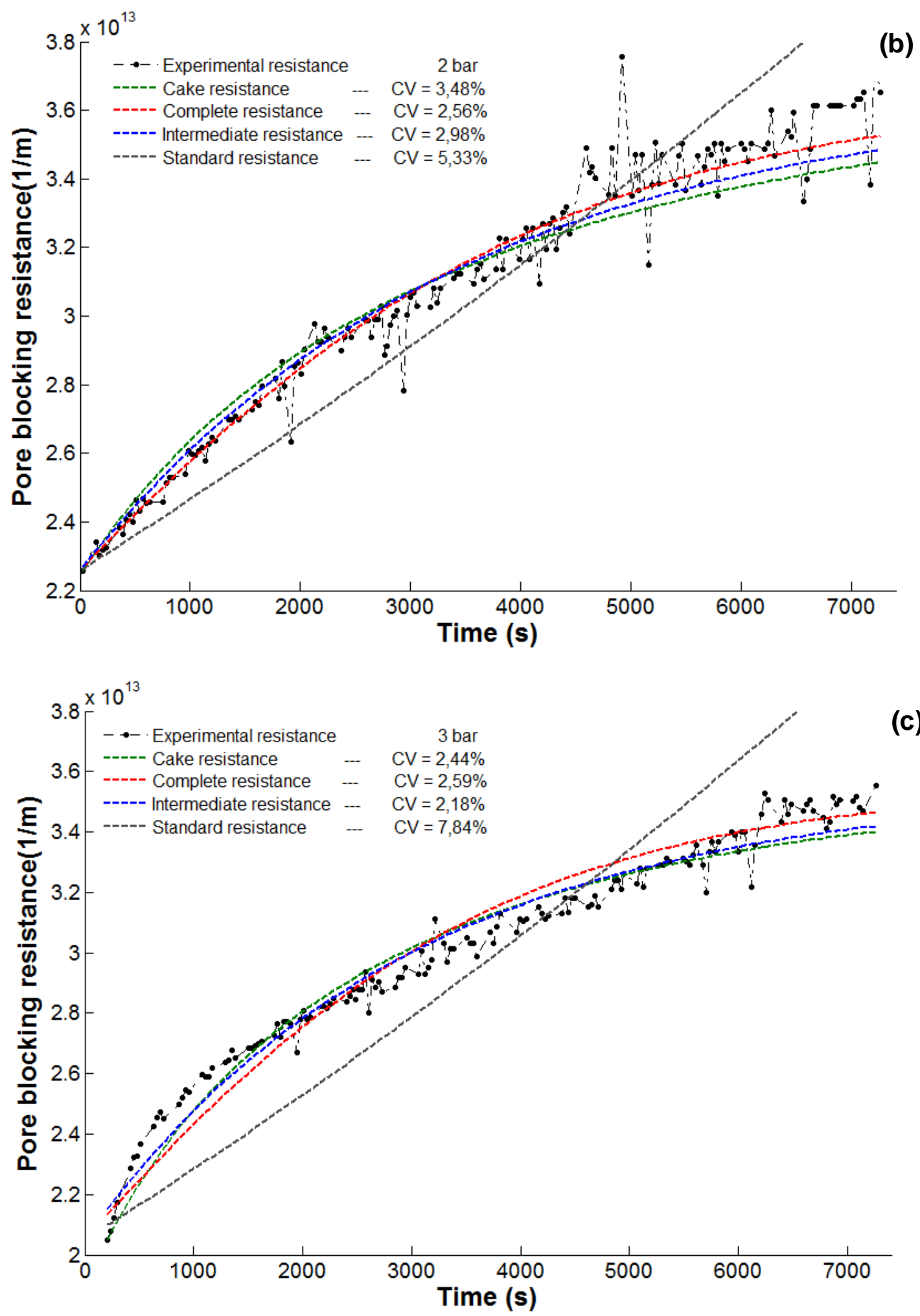

Figure 5-6 - Comparison of predictive pore blocking resistances as a function of filtration time among different models at different TMPs for UF PMTE with10 kDa PES membrane:

(a) 1.0 bar, (b) 2.0 bar and (c) 3.0 bar. 


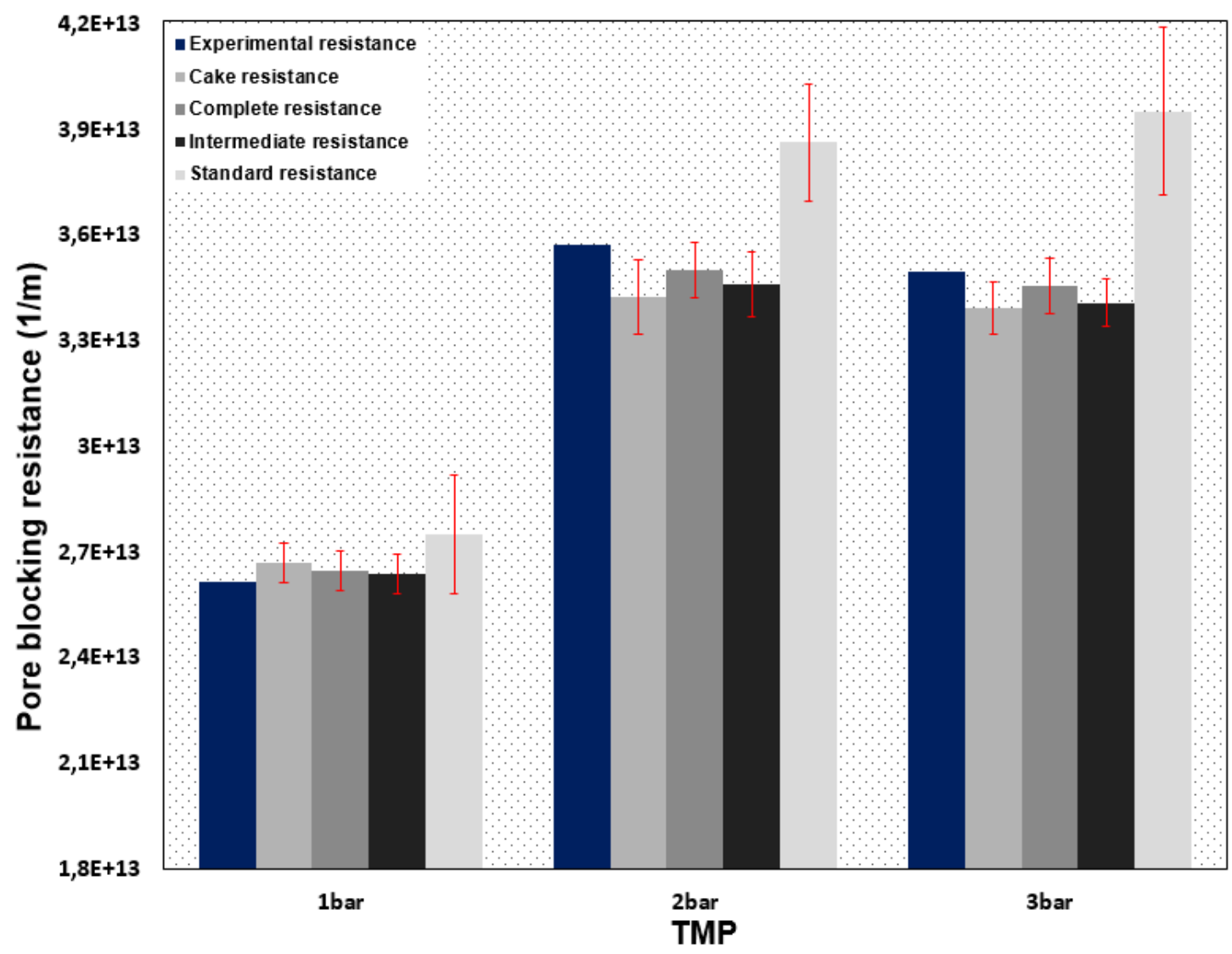

Figure 5-7 - Experimental and predicted pore blocking resistance distribution for PMTE at 10 kDa PES membrane and different TMPs. Averaged values of resistance was used and the data was modeled using Matlab ${ }^{\circledR}$ modelling programmes (Appendix B).

The result showed that the pore blocking resistance models presented good agreements with the experimental data at different TMPs. Based on Equation 5-13, TMP is a crucial driving force in cross-flow UF. Therefore, from Figure 5-6 and Figure 5-7, the highest resistance to pore blockage were observed with the increase in TMP. It could be explained that higher TMP the process needs more feed of PMTE and the organic foulants as proteins -like, fats acids and polysaccharides has more probability to penetrate through the membrane porous and consequently decreased the porosity by pore blocking, besides the accumulated on the membrane surface carry out cake formation (Hou et al., 2017). This is because increasing the pressure means increase in the hydrodynamics of mass transfer from the fouling layer to the bulk solution. 
The coefficient of residual variation (CV) between experimental data and model predictions was used to evaluate the accuracy of the pore blocking resistance models, calculated by the following equations (Strzelecki and Tomaszewski, 2018):

$$
C V=\frac{S E E}{\bar{J}_{\text {exp }}} * 100 \%
$$

Equation 5-14

where $\bar{J}_{\text {exp }}$ is the average experimental permeate flux.

The results of standard error of the estimate and coefficient of residual variation for the pore blocking resistances are shown in Table 5-4. As it can be seen from the table, with increasing TMP the differences between experimental data and fouling models increase. The standard blocking model was poor in predicting fouling resistance for all TMP, while at lower pressure (1 bar) lowest SEE and CV were found for intermediate, complete and cake resistance, respectively (very close to each other). At higher pressure (3 bar) intermediate and cake formation resistance were the best fitting with lowest SEE and CV.

Table 5-4 - Pore blocking standard error of the estimate and coefficient of residual variation between experimental data and Hermia's models against TMP.

\begin{tabular}{|c|c|c|c|c|c|c|c|c|c|}
\hline \multirow[t]{2}{*}{ TMP } & \multirow[t]{2}{*}{$\begin{array}{l}\text { Experimental } \\
\text { resistance } \\
\left(\mathrm{m}^{-1}\right) \cdot 10^{-13}\end{array}$} & \multicolumn{2}{|c|}{$\begin{array}{l}\text { Cake } \\
\text { resistance } \\
\left(\mathrm{m} \cdot \mathrm{s}^{-1}\right) \cdot 10^{-11}\end{array}$} & \multicolumn{2}{|c|}{$\begin{array}{l}\text { Complete } \\
\text { resistance } \\
\left(\mathrm{m} \cdot \mathrm{s}^{-1}\right) \cdot 10^{-11}\end{array}$} & \multicolumn{2}{|c|}{$\begin{array}{l}\text { Intermediate } \\
\text { resistance } \\
\left(\mathrm{m} \cdot \mathrm{s}^{-1}\right) \cdot 10^{-11}\end{array}$} & \multicolumn{2}{|c|}{$\begin{array}{l}\text { Standard } \\
\text { resistance } \\
\left(\mathrm{m} \cdot \mathrm{s}^{-1}\right) \cdot 10^{-12}\end{array}$} \\
\hline & & SEE & $\begin{array}{l}\text { CV } \\
(\%)\end{array}$ & SEE & $\begin{array}{l}\mathrm{CV} \\
(\%)\end{array}$ & SEE & $\begin{array}{l}\text { CV } \\
(\%)\end{array}$ & SEE & $\begin{array}{l}\mathrm{CV} \\
\text { (\%) }\end{array}$ \\
\hline 1 bar & 2,61 & 5,63 & 2,15 & 5,60 & 2,14 & 5,50 & 2,10 & 1,68 & 6,44 \\
\hline 2bar & 3,57 & 10,7 & 3,48 & 7,91 & 2,56 & 9,21 & 2,98 & 1,65 & 5,33 \\
\hline 3bar & 3,49 & 7,38 & 2,44 & 7,81 & 2,59 & 6,59 & 2,18 & 2,37 & 7,84 \\
\hline
\end{tabular}

Therefore, the intermediate and cake filtration mechanisms seems to be the main fouling resistance in UF of PMTE both presents an increasing trend with increased TMP and obviously the variations of intermediate blocking and cake formation increase with filtration time (see Figure 5 6. and Figure 5 7.). 
5.4.5 Predicting performance of constant-pressure filtration (membrane fouling)

It has previously been shown that in an UF process under constant pressure, the permeate flux declines as the resistance to the filtration increases, as the membrane pores become blocked during cake formation by retained particles (suspended solids, colloids and dissolved substances).

Furthermore, immediately after pore blockage, the permeate flux still declines due to the formation and growth of a cake layer on the membrane surface (cake filtration). A cake layer forms on the membrane surface as the growth of the retained particles increases adding to the cake layer thickness (Song, 1998, 1998b). The main reference for the mathematical model used in this article to predict permeate flux decline due to membrane fouling in an UF is the model proposed by Song. (1998) and Wang and Song, (1999). Figure 5-8 shows the flux decline for experimental ultrafiltration data and theoretical modelling.

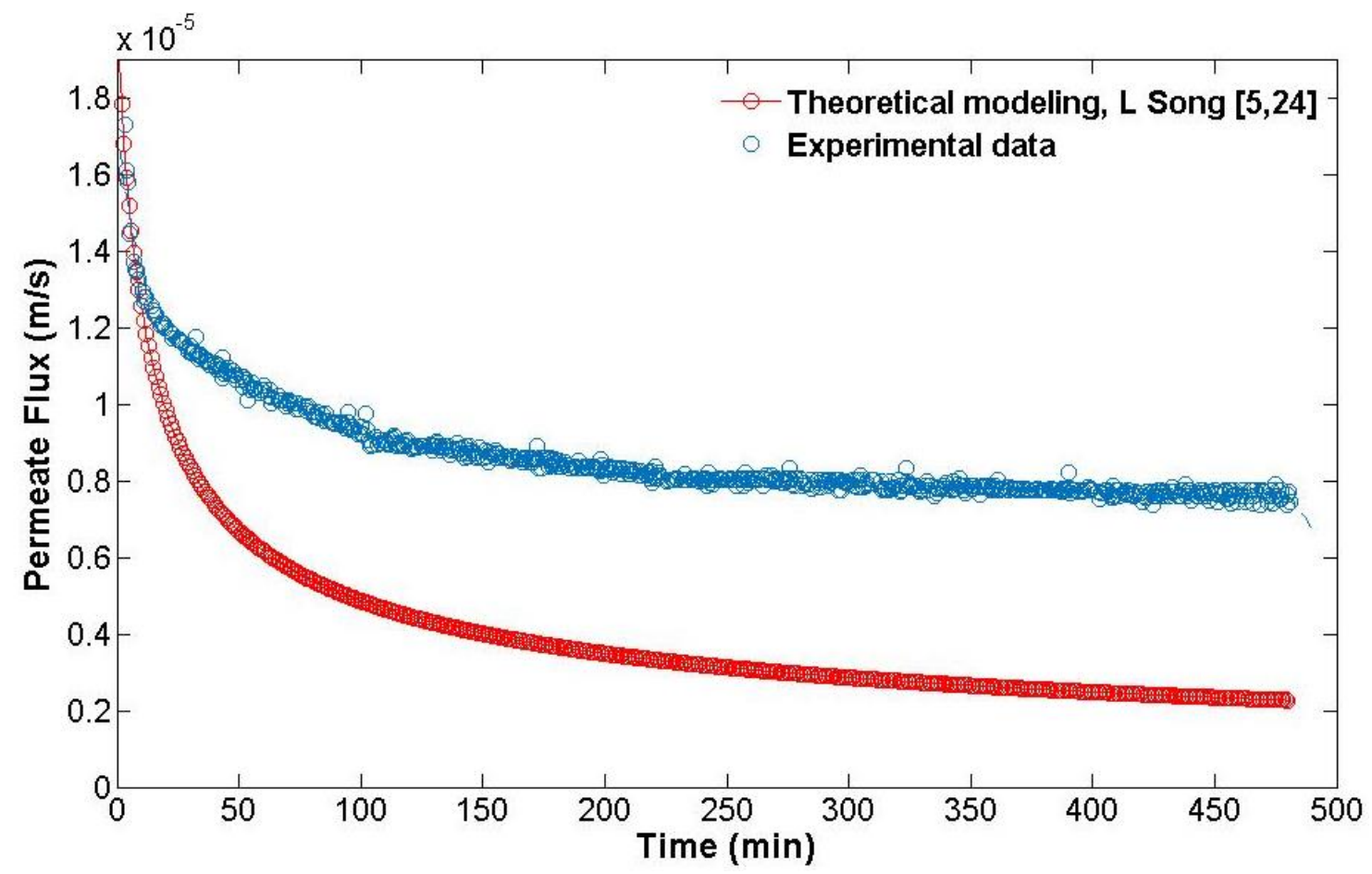

Figure 5-8 - Comparison between experimental flux decline and theoretical model for permeate flux with cross flow for a flat-sheet $10 \mathrm{kDa}$ PES membrane in cross flow filtration mode as calculated from Equation 5-9 (conditions: TMP $=3.0 \mathrm{bar}, \mathrm{Cg}=0.7, \varepsilon=0.3, \mathrm{C}_{0}=0.2 \mathrm{~g} / \mathrm{L}$,

$$
\left.a p=158 \mathrm{~nm}, R_{m}=1.65 \times 10^{12} \mathrm{~m}^{-1}\right) .
$$

During the modelling analysis of the permeate flux decline (membrane fouling), two stages of ultrafiltration were observed. The first stage corresponds to the blocking of 
the pores themselves, during which the permeate flux decreases quickly, to a negligible amount. It can be seen that the model fits the data well until about 16 minutes, when the transition to the second stage, cake layer filtration, takes place. This is the predominant filtration mechanism from around minute 50 . The permeate flux decreases from an initial value of $1.82 \times 10^{-5} \mathrm{~m} / \mathrm{s}$, corresponding to the permeability without fouling, to $7.44 \times 10^{-6} \mathrm{~m} / \mathrm{s}$ after 8 hours operation.

However, the overall system permeability reduces during both pore blocking stages. Thus, during the initial blocking period, the reduction in membrane permeability must be due to the progressive plugging of the membrane, until the cake filtration period starts. From this time on, the reduction in membrane permeability is caused by the formation of a cake structure and gel layer.

In the proposed model the specific cake resistance per unit cake thickness was $r_{c}=3.00 \times 10^{12} \mathrm{~m}^{2}$ which can be approximately related to the properties for spherical particles given by the Carman-Kozeny relationship in Equation 2-32 (Chudacek and Fane, 1984; Davis, 1992; Song, 1998b).

Based on previous studies and empirical observations of granular media filtration of rigid spherical particles (Letterman and American Water Works Association, 1999; Vidal et al., 2009), the model assumed a Kozeny constant of around $4.9<\mathrm{K} 7.1$ and a constant porosity of around 0.36. A particle volume fraction of 0.64 was assumed for the specific resistance of cake structures with a constant concentration, however, in reality, for colloidal and dissolved substances the particles are most commonly polydisperse and compressible, therefore, the porosity within the cake layer and the cake permeability should vary temporally. For low-pressure membrane operations (experimental data 3 bar), it was assumed the filtration number and porosity of the retained particles corresponds to $\mathrm{Nf}>15$ (packing porosity of about 0.36 ) for the idealised situation of monodisperse suspensions of rigid spheres (Chen et al., 2015b; Ho and Zydney, 2000; Song, 1998b). Figure 5-9 show the resistance of the cake layer (Equation 5-10) and cake thickness (Equation 5-11Equation 5-11) as a function of UF time (8 hours). 

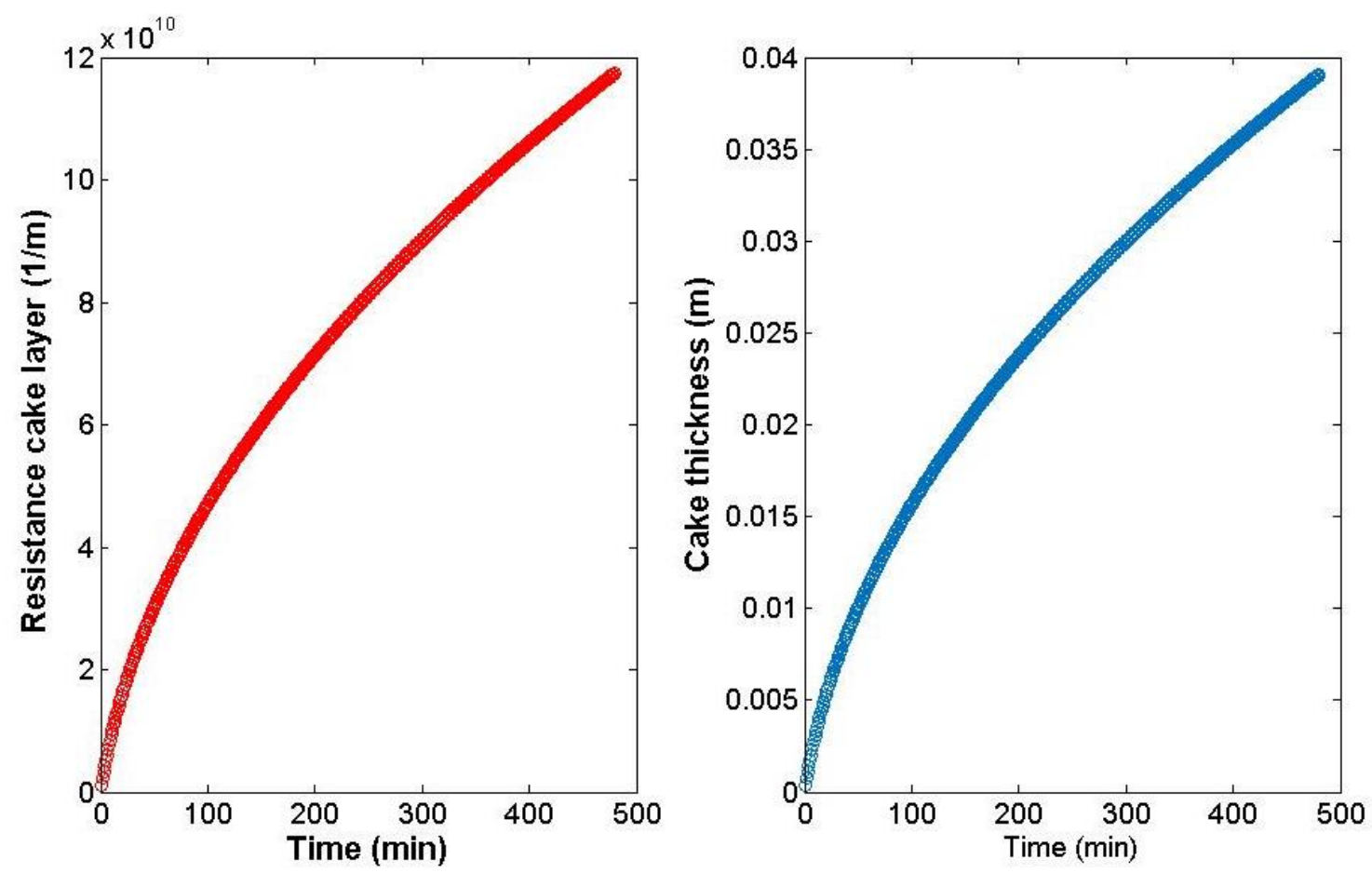

Figure 5-9 - Resistance of the cake layer and cake thickness as a function of UF time (8 h) in flat-sheet, crossflow filtration at constant pressure . Conditions TMP $=3.0$ bar, $\mathrm{Cg}=0.7, \varepsilon=$ $0.3, \mathrm{C}_{0}=0.2 \mathrm{~g} / \mathrm{L}, \mathrm{ap}=158 \mathrm{~nm}, \mathrm{Rm}=1.65 \times 10^{12} \mathrm{~m}^{-1}, \mathrm{rc}=3.01 \times 10^{12}\left(\mathrm{~m}^{-2}\right)$.

According to research performed by Chen et al. (2015) and Puro et al. (2002a), the foulants on the membrane surface and within pores arise from DCS, especially fatty acids, resin acids, lignins and some traces of sterols, steryl esters and triglycerides. Moreover, the presence of dissolved multivalent metal ions, especially $\mathrm{Ca}^{2+}$, accelerated membrane fouling (Puro et al., 2011a, 2002b). Although the approach of this work has been to demonstrate and model the membrane fouling mechanism, the main objective of the follow-on research will be the characterisation of the foulants and the identification of the specific chemical components on the surface and within the membrane. This will be undertaken using techniques such as scanning electron microscope (SEM), Fourier transform infrared (FTIR) spectroscopy, Three-dimensional excitation and emission matrix fluorescence (3DEEM) and gas chromatography-mass spectrometry (GC-MS) (Chen et al., 2015a; Puro et al., 2011a, 2002b) .

\subsubsection{Determination of membrane cleaning efficiency}

In this current study, nine cleaning cycles was performed after each 30 minutes UF to remove membrane foulants, establish the flux recovery and determine the resistance removal for hydraulic and chemical cleaning. In addiction, provides an initial insight about the effects of reversible and irreversible fouling on membrane. 
The fouled membranes was backwashed (for 20 minutes) with DI water to determine the hydraulic fouling reversibility and chemically cleaned with aqueous $1.0 \mathrm{M} \mathrm{NaOH}$ solution at $\mathrm{pH} 9.5$ in a total cleaning bath for 30 minutes, according to described in Cleaning membranes procedure (Section 3.5.4).

Figure 5-10 shows the normalised flux recovery by hydraulic and chemical cleaning as a function of each filtration cycle for a $10 \mathrm{kDa}$ PES membrane under operating conditions of $22^{\circ} \mathrm{C}, 3.0$ bar and $4.5 \mathrm{l} / \mathrm{min}$.

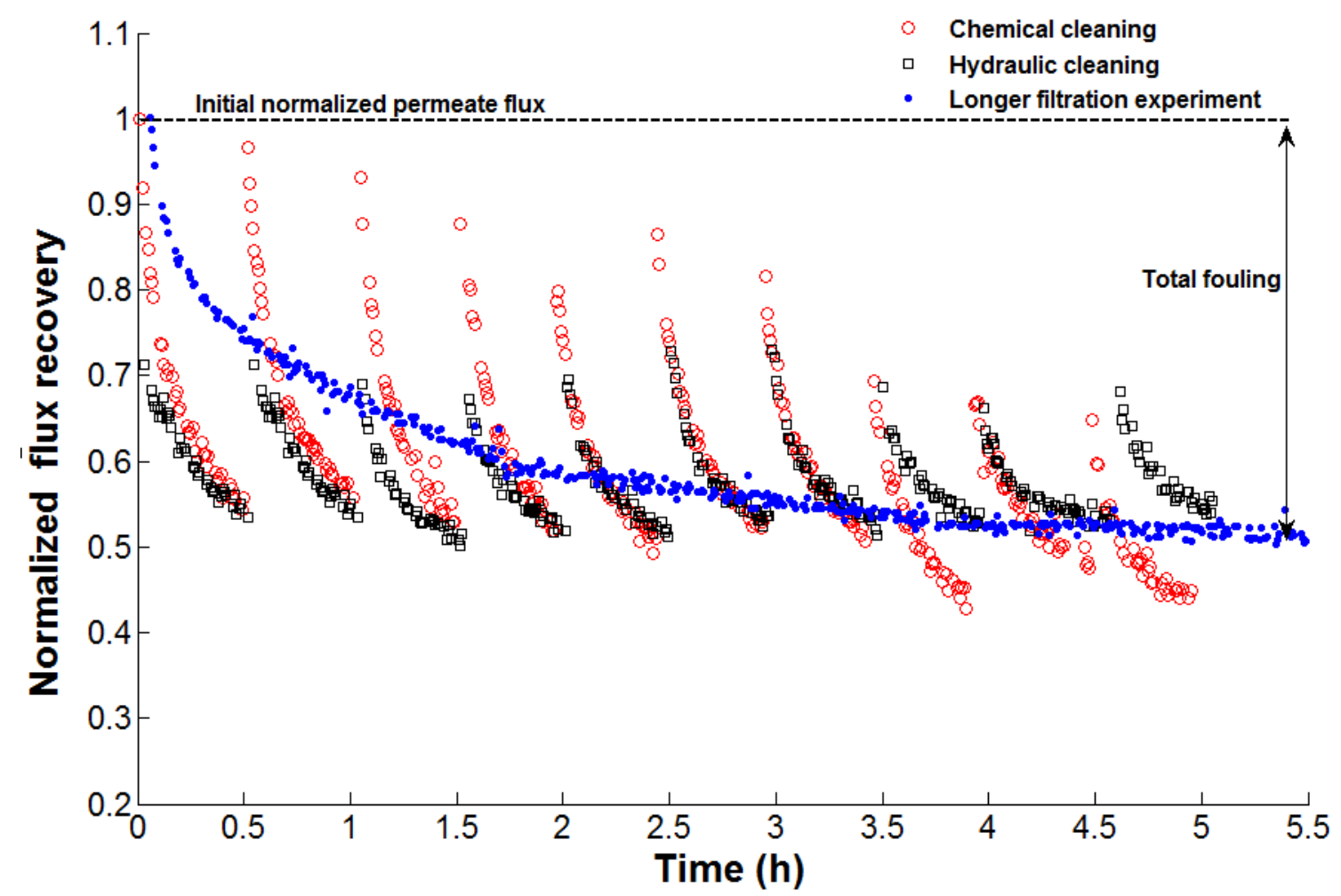

Figure 5-10 - Normalised flux recovery $\left(\mathrm{J}_{\mathrm{p}(\mathrm{t})} / \mathrm{J}_{0}\right)$ by chemical and hydraulic methods. Initial permeate flux was $55.12 \pm 1.0 \mathrm{~L} / \mathrm{m}^{2} \mathrm{~h}$ and resistance by total fouling $2.26 \times 10^{13} \mathrm{~m}^{-1}$.

As a result for a longer UF experiment (5.5 hour without cleaning cycles) the permeate flux was about $28.8 \pm 0.5 \mathrm{~L} / \mathrm{m}^{2} / \mathrm{h}$ (representing at the end of the process a $47.6 \%$ reduction of initial permeate). Moreover, membrane fouling took place with a higher rate in the first 60 minutes reducing gradually to around $32.0 \% \pm 0.5$ of the initial flux $\left(55.12 \pm 1.0 \mathrm{~L} / \mathrm{m}^{2} \mathrm{~h}\right)$. Therefore, is clearly that cleaning is required to maintain the permeate flux and integrity of the membrane.

May be appreciate from Figure 5-10, through cleaning cycling that chemical cleaning presents high flux recovery in comparison with hydraulic cleaning, average values around $82.31 \%$ and $69.65 \%$, respectively.Therefore, permeate at the beginning of 
each cycle were taken after hydraulic and chemical cleaning in order to determine flux recovery and resistance removal. Table 5-5 compares permeate flux values from the beginning of each cycle.

Table 5-5 - Membrane flux recovery after each cleaning step with DI water in backwash and $\mathrm{NaOH}$. Initial permeate flux $55.5 \pm 1.0 \mathrm{~L} / \mathrm{m}^{2} \mathrm{~h}$.

\begin{tabular}{|c|c|c|c|c|c|c|c|}
\hline & $\begin{array}{c}\mathbf{J}_{\mathbf{p}} \\
\text { after } \\
\text { chemical } \\
\text { cleaning } \\
\left(\mathrm{L} / \mathrm{m}^{2} \mathrm{~h}\right)\end{array}$ & $\begin{array}{c}\mathbf{J}_{\text {recovery }} \\
\text { by chemical } \\
\text { cleaning } \\
(\%)\end{array}$ & $\begin{array}{c}\mathbf{J}_{\mathbf{p}} \\
\text { after } \\
\text { hydraulic } \\
\text { cleaning } \\
\left(\mathrm{L} / \mathrm{m}^{2} \mathrm{~h}\right)\end{array}$ & $\begin{array}{c}\text { Jrecovery } \\
\text { by Hydraulic } \\
\text { cleaning } \\
(\%)\end{array}$ & $\begin{array}{l}\text { Resistance } \\
\text { by total } \\
\text { fouling } \\
\left(\mathrm{m}^{-1}\right)\end{array}$ & $\begin{array}{c}\mathbf{R}_{\text {irrev. }} \\
\text { after } \\
\text { chemical } \\
\text { cleaning } \\
\left(\mathrm{m}^{-1}\right)\end{array}$ & $\begin{array}{c}\mathbf{R}_{\text {irrev. }} \\
\text { after } \\
\text { hydraulic } \\
\text { cleaning } \\
\left(\mathrm{m}^{-1}\right)\end{array}$ \\
\hline 1 Ciclo & 53.31 & 996.70 & 39.31 & 71.30 & $2.05 \times 10^{13}$ & $4.65 \times 10^{12}$ & $1.22 \times 10^{13}$ \\
\hline 2 Ciclo & 51.38 & 93.21 & 38.05 & 69.02 & $1.94 \times 10^{13}$ & $5.44 \times 10^{12}$ & $1.32 \times 10^{13}$ \\
\hline 3 Ciclo & 48.38 & 87.77 & 37.08 & 67.27 & $2.15 \times 10^{13}$ & $6.81 \times 10^{12}$ & $1.39 \times 10^{13}$ \\
\hline 4 Ciclo & 43.36 & 78.65 & 37.87 & 68.70 & $2.30 \times 10^{13}$ & $9.52 \times 10^{12}$ & $1.33 \times 10^{13}$ \\
\hline 5 Ciclo & 47.64 & 86.42 & 40.17 & 72.87 & $2.37 \times 10^{13}$ & $7.17 \times 10^{12}$ & $1.16 \times 10^{13}$ \\
\hline 6 Ciclo & 44.03 & 79.86 & 40.29 & 73.08 & $2.25 \times 10^{13}$ & $9.12 \times 10^{12}$ & $1.15 \times 10^{13}$ \\
\hline 7 Ciclo & 38.22 & 69.34 & 37.88 & 68.71 & $2.40 \times 10^{13}$ & $1.30 \times 10^{13}$ & $1.33 \times 10^{13}$ \\
\hline 8 Ciclo & 36.67 & 66.52 & 36.52 & 66.24 & $2.95 \times 10^{13}$ & $1.43 \times 10^{13}$ & $1.44 \times 10^{13}$ \\
\hline
\end{tabular}

It is easy to see that flux recovery by chemical cleaning decreases from the first to the later of the UF, while $\boldsymbol{J}_{\text {recovery }}$ by hydraulic cleaning remains with less variation within range of $69.66 \pm 3.42 \% \tilde{n} 77$. From chemical and hydraulic cleaning, the highest $J_{\text {recovery }}$ were of $96.70 \%\left(53.31 \mathrm{~L} / \mathrm{m}^{2} \mathrm{~h}\right)$ in the $1^{\text {th }}$ cycle and $73.08 \%\left(40.29 \mathrm{~L} / \mathrm{m}^{2} \mathrm{~h}\right)$ in the $6^{\text {th }}$ cycle, respectively.

Moreover, resistence by membrane fouling presents a decrease through cleaning cycling, that is to say, in the first UF cycle the fouling was less significant compared than the $2^{\text {nd }}$ and $3^{\text {rd }}$ cycle and so go ahead. In addition, it is worth noting the decrease in membrane permeability at the end of each cycle, from a cycle to cycle, is an indication of the irreversible fouling accumulating with each cycle.

The fouling removal as show in Equation 3-5 was used to evaluate the cleaning efficiency as described in section 3.5.4. Figure 5-11 shows the resistance removal for DI water and $\mathrm{NaOH}$. It was observed that $\mathrm{DI}$ water in backwash achived more severe irreversible fouling (less RR) than $\mathrm{NaOH}$, suggesting that there are higher fraction of organic foulants as small colloids and dissolved matter on fouled membranes. 
Thereby, higher flux recovery and resistance removal were found when the fouled UF membrane was cleaned with $\mathrm{NaOH}$.

It is worth mentioning that the previous studies carried out by Simon et al. (2013) have found that caustic and alkaline agents as effective in the removal of organic fouling, due the capacity to loosen and dissolve the foulants deposited on the membrane surface as a cake layer and hydrolyses proteins and polysaccharides one of the main constituents of DCS in PMTE and responsible for the cake layer on membrane surface. However, in this study even with $\mathrm{NaOH}$ the cleaning performed was not so high effective, with resistance removal within the range of $32.18 \%-51.12 \%$ and $42.98 \%-$ $77.30 \%$ for hydraulic and chemical methods, respectively, which means that important portion of the foulants is not successfully removed, suggesting that cleaning procedure is inappropriate for the $10 \mathrm{kDa}$ PES membrane fouled by PMTE.

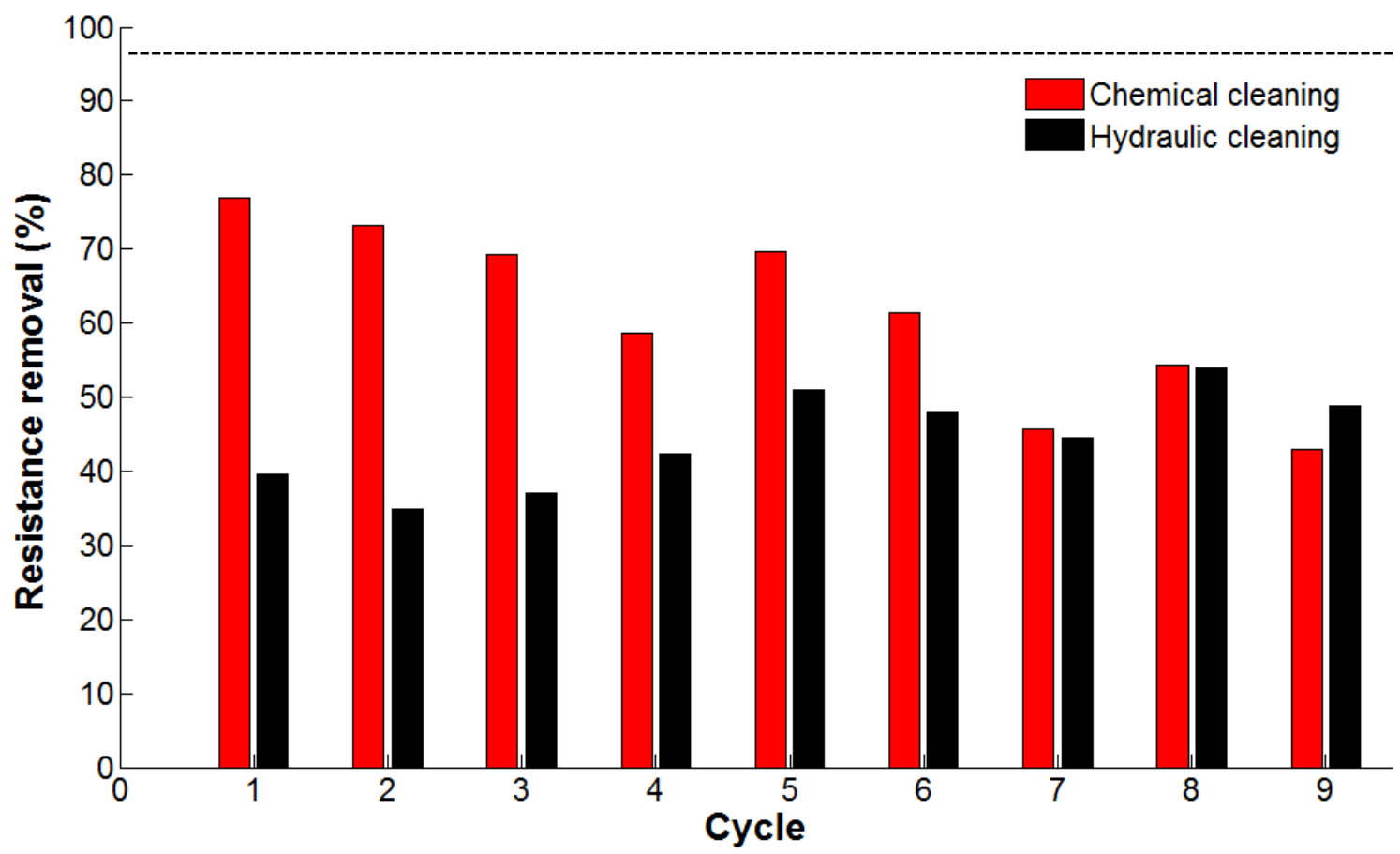

Figure 5-11 - Membrane resistance removal at various filtration cycles by chemical and hydraulic methods. 


\subsection{Conclusion}

In this work, ultrafiltration was used to remove dissolved and colloidal substances remaining in the effluent from a papermaking factory wastewater treatment plant. The results show that these substances cause a significant permeate flux decline resulting from membrane fouling.

From the modified Hermia's models studied in this work it is clear that intermediate and complete blocking can explain the experimental results obtained for all the experimental conditions with a high goodness of fit $\left(R^{2}>0.96\right)$.

The best conditions for UF providing the highest flux were found at TMP $=3$ bar and a crossflow rate of $4.5 \mathrm{~L} / \mathrm{min}$ at $22{ }^{\circ} \mathrm{C} \pm 0.5^{\circ} \mathrm{C}$. The particle size distribution was greatly decreased from the range of $5499.1-188.7 \mathrm{~nm}$ to 334.2 - $99.1 \mathrm{~nm}$. As a consequence, the turbidity was reduced by $99 \%$, and the organic colloidal matter was effectively eliminated, considering that its average size is greater than $220 \mathrm{~nm}$. In addition, as COD was removed by $54 \%$ down to $110 \mathrm{mg} / \mathrm{L}$ it could be concluded that ultrafiltration is suitable for producing water that can be reused in different papermaking processes. Modelling of the membrane processes is of interest since it aids the selection of a suitable TMP and crossflow rate. This is positive from an operational point of view because, by manipulating the operating conditions, it is possible to obtain better control of the membrane fouling processes.

The performance of the membrane cleaning was quantified using flux recovery and resistance removal. The results demonstrated that $\mathrm{NaOH}$ was more effective than $\mathrm{DI}$ water in backwash, futhermore suggests that reversible fouling is associated with colloidal substances, these results are consistent with presented in Chapter 5, which identify that colloidal substances and protein-like matter as the main contributors to reversible fouling, whereas humic and fulvic acid were the main contributors to irreversible fouling (dead - end cleaning protocol). However, in this section cleaning procedure was not extensively investigated, because is required time and intensive work, therefore, a more comprehensive investigation is required to a better understanding of cleaning solutions and the interactions between foulants and PES membranes. 


\subsection{References}

Beril Gönder, Z., Arayici, S., Barlas, H., 2011. Advanced treatment of pulp and paper mill wastewater by nanofiltration process: Effects of operating conditions on membrane fouling. Separation and Purification Technology 76, 292-302. https://doi.org/10.1016/j.seppur.2010.10.018

Bhattacharjee, S., Datta, S., Bhattacharjee, C., 2007. Improvement of wastewater quality parameters by sedimentation followed by tertiary treatments. Desalination 212, 92-102. https://doi.org/10.1016/j.desal.2006.08.014

Brião, V.B., Tavares, C.R.G., 2012. Pore blocking mechanism for the recovery of milk solids from dairy wastewater by ultrafiltration. Brazilian Jou rnal of Chemical Engineering 29, 393-407. https://doi.org/10.1590/S0104-66322012000200019

Carroll, T., King, S., Gray, S.R., Bolto, B.A., Booker, N.A., 2000. The fouling of microfiltration membranes by NOM after coagulation treatment. Water Research 34, 2861-2868. https://doi.org/10.1016/S0043-1354(00)00051-8

Chen, C., Mao, S., Wang, J., Bao, J., Xu, H., Su, W., Dai, H., 2015a. Application of Ultrafiltration in a Paper Mill: Process Water Reuse and Membrane Fouling Analysis. BioResources 10 , $2376-2391$. https://doi.org/10.15376/biores.10.2.2376-2391

Chen, C., Mao, S., Wang, J., Bao, J., Xu, H., Su, W., Dai, H., 2015b. Application of Ultrafiltration in a Paper Mill: Process Water Reuse and Membrane Fouling Analysis. BioResources 10, 2376-2391. https://doi.org/10.15376/biores.10.2.2376-2391

Chudacek, M.W., Fane, A.G., 1984. The dynamics of polarisation in unstirred and stirred ultrafiltration. Journal of Membrane Science 21, 145-160. https://doi.org/10.1016/S0376-7388(00)81551-3

Corbatón-Báguena, M.-J., Álvarez, S., Vincent-Vela, M.-C., 2017. Ultrafiltration of whey: membrane performance and modelling using a combined pore blockingcake formation model. Journal of Chemical Technology \& Biotech nology 93. https://doi.org/10.1002/jctb.5446 
Corbatón-Báguena, M.-J., Álvarez-Blanco, S., Vincent-Vela, M.-C., 2015. Fouling mechanisms of ultrafiltration membranes fouled with whey model solutions. Desalination 360, 87-96. https://doi.org/10.1016/j.desal.2015.01.019

Davis, R.H., 1992. Modeling of Fouling of Crossflow Microfiltration Membranes. Separation and Purification Methods 21, 75-126. https://doi.org/10.1080/03602549208021420

de Barros, S.T.D., Andrade, C.M.G., Mendes, E.S., Peres, L., 2003. Study of fouling mechanism in pineapple juice clarification by ultrafiltration. Journal of Membrane Science 215, 213-224. https://doi.org/10.1016/S03767388(02)00615-4

Field, R.W., Wu, D., Howell, J.A., Gupta, B.B., 1995. Critical flux concept for microfiltration fouling. Journal of Membrane Science 100, 259-272. https://doi.org/10.1016/0376-7388(94)00265-Z

Gimenes, M., R. Silva, V., Hamerski, F., Scheer, A., 2014. Pretreatment of Aqueous Pectin Solution by Cross-Flow Microfiltration: Study on Fouling Mechanism. International Journal of Chemical Engineering and Applications 5, 281-286. https://doi.org/10.7763/IJCEA.2014.V5.394

Hermia, J., 1982. Constant Pressure Blocking Filtration Laws - Application To Power-law Non-newtonian Fluids. Institution of Chemical Engineers. Transactions 60, 183.

Ho, C.-C., Zydney, A.L., 2000. A Combined Pore Blockage and Cake Filtration Model for Protein Fouling during Microfiltration. Journal of Colloid and Interface Science 232, 389-399. https://doi.org/10.1006/jcis.2000.7231

Hou, L., Wang, Z., Song,P., 2017. A precise combined complete blocking and cake filtration model for describing the flux variation in membrane filtration process with BSA solution. Journal of Membrane Science 542, 186-194. https://doi.org/10.1016/j.memsci.2017.08.013

Jacob, J., Prádanos, P., Calvo, J.I., Hernández, A., Jonsson, G., 1998. Fouling kinetics and associated dynamics of structural modifications. Colloids and Surfaces A: Physicochemical and Engineering Aspects 138, 173-183. https://doi.org/10.1016/S0927-7757(97)00082-4 
Letterman, R.D., American Water Works Association (Eds.), 1999. Water quality and treatment: a handbook of community water supplies, 5th ed. ed. McGrawHill, New York.

Liang, J., He, Y., Zhu, J., Wenjing, D., 2011. Accumulation of dissolved and colloidal substances in water recycled during papermaking. Chemical Engineering Journal - CHEM ENG J 168, 604-609. https://doi.org/10.1016/j.cej.2011.01.030

Lin, S.-H., Hung, C.-L., Juang, R.-S., 2008. Applicability of the exponential time dependence of flux decline during dead-end ultrafiltration of binary protein solutions. Chemical Engineering Journal 145, 211-217. https://doi.org/10.1016/j.cej.2008.04.003

Mulder, J., 1996. Basic Principles of Membrane Technology, 2nd ed. Springer Netherlands.

Ohanessian, K., Monnot, M., Moulin, P., Ferrasse, J.-H., Barca, C., Soric, A., Boutin, O., 2020. Dead-end and crossflow ultrafiltration process modelling: Application on chemical mechanical polishing wastewaters. Chemical Engineering Research and Design 158, 164-176. https://doi.org/10.1016/j.cherd.2020.04.007

Peng, W., Escobar, I., White, D., 2004. Effects of water quality and membrane properties on performance and fouling-A model developmentstudy. Journal of Membrane Science 238, 33-46. https://doi.org/10.1016/j.memsci.2004.02.035

Puro, L., Kallioinen, M., Mänttäri, M., Nyström, M., 2011. Evaluation of behavior and fouling potential of wood extractives in ultrafiltration of pulp and paper mill process water. Journal of Membrane Science 368, 150-158. https://doi.org/10.1016/j.memsci.2010.11.032

Puro, L., Tanninen, J., Nyström, M., 2002. Analyses of organic foulants in membranes fouled by pulp and paper mill effluent using solid-liquid extraction. Desalination 143, 1-9. https://doi.org/10.1016/S0011-9164(02)00215-1

Sanaei, P., Cummings, L.J., 2017. Flow and fouling in membrane filters: effects of membrane morphology. Journal of Fluid Mechanics 818, 744-771. https://doi.org/10.1017/jfm.2017.102 
Silva, R.I. da, Brandão, E.C.V., Brito, J.C.M. de, Figueiredo, K.C. de S., 2020. Analysis of fouling mechanisms and membrane cleaning du ring ultrafiltration of bee venom. Separation Science and Technology 55, 988-993. https://doi.org/10.1080/01496395.2019.1577455

Simon, A., Price, W.E., Nghiem, L.D., 2013. Changes in surface properties and separation efficiency of a nanofiltration membrane after repeated fouling and chemical cleaning cycles. Separation and Purification Technology 113, 42-50. https://doi.org/10.1016/j.seppur.2013.04.011

Song, L., 1998a. Flux decline in crossflow microfiltration and ultrafiltration: mechanisms and modeling of membrane fouling. Journal of Membrane Science 139, 183-200. https://doi.org/10.1016/S0376-7388(97)00263-9

Song, L., 1998b. A New Model for the Calculation of the Limiting Flux in Ultrafiltration. Journal of Membrane Science 144, 173-185. https://doi.org/10.1016/S0376-7388(98)00057-X

Song, L., 1998c. Flux decline in crossflow microfiltration and ultrafiltration: mechanisms and modeling of membrane fouling. Journal of Membrane Science 139, 183-200. https://doi.org/10.1016/S0376-7388(97)00263-9

Strzelecki, P., Tomaszewski, T., 2018. Analysis of axial load and bending load effects on the fatigue life. Presented at the AIP Conference Proceedings, $p$. 020019. https://doi.org/10.1063/1.5066409

Vela, M.C.V., Blanco, S.Á., García, J.L., Rodríguez, E.B., 2008. Analysis of membrane pore blocking models applied to the ultrafiltration of PEG. Separation and Purification Technology 62, 489-498. https://doi.org/10.1016/j.seppur.2008.02.028

Vidal, D., Ridgway, C., Pianet, G., Schoelkopf,J., Roy, R., Bertrand, F., 2009. Effect of particle size distribution and packing compression on fluid permeability as predicted by lattice-Boltzmann simulations. Computers \& Chemical Engineering 33, 256-266. https://doi.org/10.1016/j.compchemeng.2008.09.003

Vincent Vela, M.C., Álvarez Blanco, S., Lora García, J., Bergantiños Rodríguez, E., 2009. Analysis of membrane pore blocking models adapted to crossflow 
ultrafiltration in the ultrafiltration of PEG. Chemical Engineering Journal 149, 232-241. https://doi.org/10.1016/j.cej.2008.10.027

Wang, L., Song, L., 1999. Flux Decline in Crossflow Microfiltration and Ultrafiltration: Experimental Verification of Fouling Dynamics. Journal of Membrane Science 160, 41-50. https://doi.org/10.1016/S0376-7388(99)00075-7

Xu, Y., Li, Y., Hou, Y., 2019. Reducing ultrafiltration membrane fouling during recycled paper mill wastewater treatment using pretreatment technologies: a comparison between coagulation and Fenton. Journal of Chemical Technology \& Biotechnology 94, 804-811. https://doi.org/10.1002/jctb.5826 
6 CHAPTER: IDENTIFICATION OF FOULANTS ON POLYETHERSULFONE (PES) MEMBRANES USED TO REMOVE COLLOIDS AND DISSOLVED MATTER FROM A PAPER MILL TREATED EFFLUENT 


\subsection{Abstract}

In this study, membrane fouling caused by paperboard mill treated effluent (PMTE) was investigated, based on a Dead-end ultrafiltration (UF) pilot-scale study. The membranes employed were commercial hydrophobic UF membranes made of polyethersulfone (PES) with a molecularweightcut-off of $10 \mathrm{kDa}, 50 \mathrm{kDa}$ and $100 \mathrm{kDa}$. Membrane fouling mechanism during dead-end filtration, chemical analysis, field emission scanning electron microscopy (FESEM), energy-dispersive spectrophotometry (EDS), attenuated total reflection-Fourier transform infrared (ATRFTIR) spectroscopy and 3D fluorescence excitation-emission matrix (3DEEM) analysis were applied to understand which fraction of the Dissolved and Colloidal Substances (DCS) caused the membrane fouling.

The results indicated that the phenomenon controlling fouling mechanism tended to be cake layer formation $\left(R^{2} \geq 0.98\right)$ for all membranes tested. The 3DEEM results indicate that the majority of the organic foulants with fluorescence characteristics on the membrane were colloidal proteins (protein -like substances I+II) and macromolecular proteins (SMP-like substances). In addition, polysaccharide (cellulosic species), fatty and resin acid substances were identified on the fouled membrane by the ATR-FTIR analysis playing an important role in membrane fouling. In addition, the FESEM and EDS analyses indicate that the presence of inorganic foulants on the membrane surfaces, such as metal ions and especially $\mathrm{Ca}^{2+}$, can accelerate membrane fouling whereas $\mathrm{Mg}$ and Si are linked to reversible fouling.

\subsection{Introduction}

The diversity of raw materials used in recycled cardboards papers requires a great knowledge of water circuits in order to adopt an adequate decision in internal water recycling. In a conventional carboard paper mill, several water loops can be present with a different use into a paper production (Figure 6-1): short circuits are water recycling without treatment. Other internal water circulation named long circuits are produced after flotation or clarification as first wastewater process or as an optimized treated water recycling after primary, secondary and tertiary wastewater treatments (Bayr and Rintala, 2012; Ordóñez et al., 2010; Rudolph et al., 2018). The most implanted wastewater treatment as a secondary process is biological treatment, in one 
(Anaerobic treatment) or two stages (Anaerobic and aerobic treatment), depending on the capacity or the required effluentquality. This conventional treatment methods have been used to treat the wastewater from different paper mills, but, in some cases, the conventional methods are insufficient to comply with the most stringent environmental regulations on effluent quality and/or for the process water to be reused in papermaking.

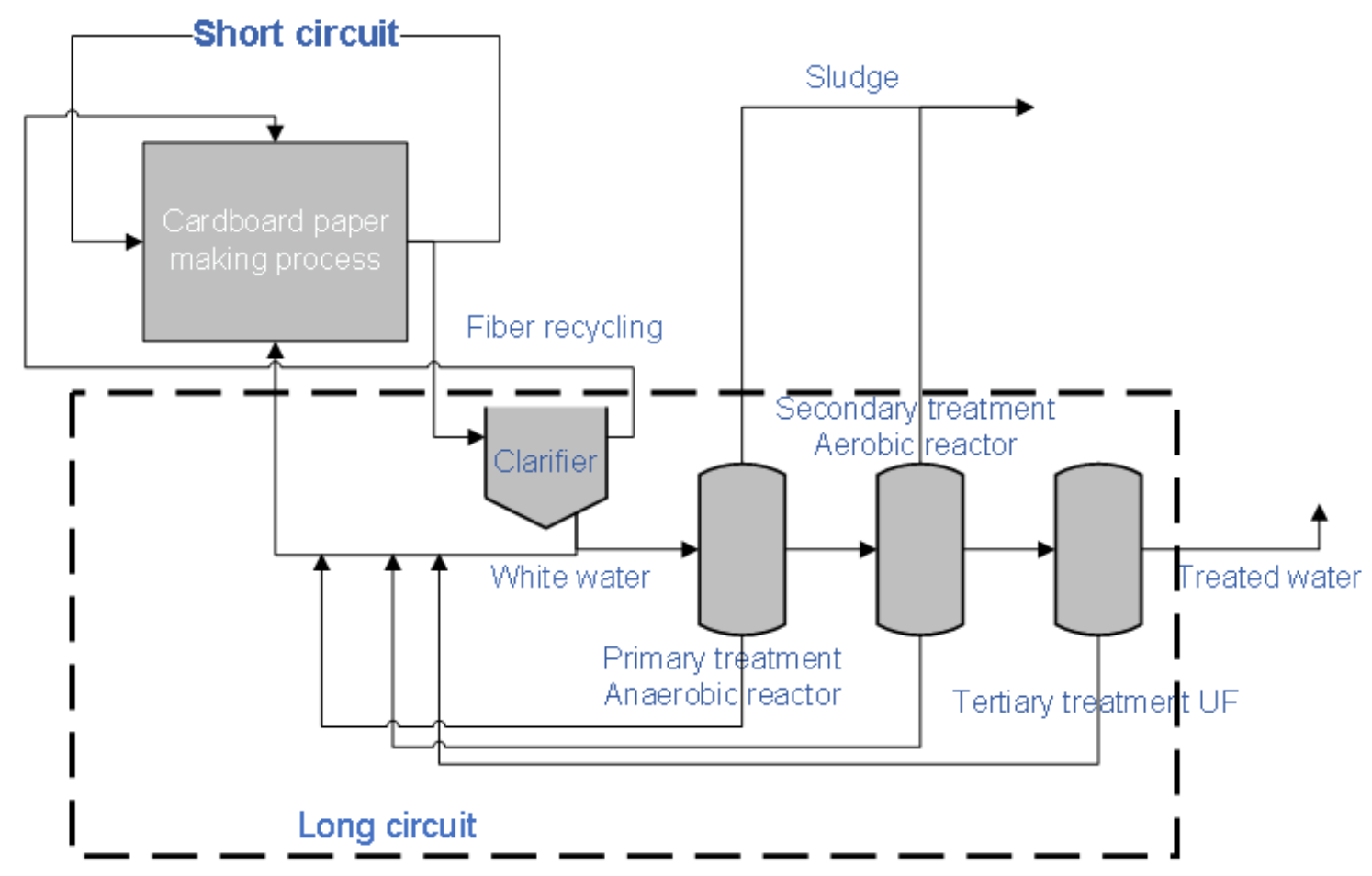

Figure 6-1 - Flow chart of the recovery process of water in the cardboard paper making process.

Due to biological treatments limitations to reach adequate water quality, membrane separation technology has attracted increasing attention as a tertiary treatment for these treated effluents from paper mills, particularly as it facilitates subsequenteffluent recycling (Chen et al., 2015a; Puro et al., 2010; Zaidi et al., 1992).

Many authors had studied ultrafiltration as main treatment to remove the Dissolved and Colloidal Substances (DCS) concentrated during the recycling of white water. In these works, studies of membrane fouling problem, material that is retained at the membrane surface or inside the membrane pores, and analysis of DCS had been presented (Chen et al., 2015; Hubbe et al., 2012; Liu et al., 2020; Puro et al., 2002; Sousa et al., 2018). Although, there are many studies about fouling problem in white water, optimize closed water loop in long circuit after secondary treatment requires UF filtration process in 
order to make possible producing the highest water quality from the final effluent of the paper mill and/or reduce fresh water (Rudolph et al., 2018; Shukla et al., 2015; Winter et al., 2017).

In pulp and paper mill effluent, Dissolved and Colloidal Substances DCS have been considered to be the major membrane foulants (Chen et al., 2015a; Hubbe et al., 2012; Puro et al., 2002a; Sousa et al., 2020). Moreover, these foulants include some fluorescent organic compounds (FOC) such as protein-like substances, humic-like substances and fulvic-like substances (Poojamnong et al., 2020).

These FOCs can be differentiated with high sensitivity due to their respective fluorescence properties in the ultraviolet and visible range (Tian et al., 2015). Therefore, 3DEEM analysis can be used as a powerful technique for the identification and characterization of this foulants on a membrane (C. Jacquin et al., 2018; Jacquin et al., 2017; Yu et al., 2020), besides to contribute with information to establish strategies for process optimization in order to prevent and eliminate this undesirable phenomenon (Peiris et al., 2010; Peldszus et al., 2011; Yu et al., 2014; Z. Wang et al., 2009). It is worth mentioning that 3DEEM can only be used to characterize FOCs. However, most of the polysaccharides comprising the DCS, which also significantly contribute in membrane fouling, cannot be suitably characterized by fluorescence.

Therefore, this chapter is focused in analyze the fouling process in UF filtration as a tertiary treatment after biological process. Biological process will modify organic substances presents in white waters and also will produce new organic substances from biological sludge. Hence, a good knowledge of characteristics substances present in these waters is important to help minimize membrane fouling (Kossar et al., 2013), aiming to obtain high quality water from UF filtration that may replace fresh water use in some applications. Furthermore, in the literature investigations about foulants characteristics had received little attention in comparison with studies focused on membrane performance and water quality.

Moreover, will be helpful to provide more detailed understanding about chemical composition, and possible origin s of membrane foulants and fouling mechanism d uring the UF process for the removal of the DCS come from a paper mill secondary effluent, that can be used as a tool to control membrane fouling, and determine whether UF process is an adequate technology or the energy, operation and investment costs, due to fouling problems, restrict the use of this filtration type. 
In order to understand DCS composition from paper mill treated biological effluent (PMTE), batch dead-end UF with different polyethersulfone (PES) membranes were used. Resistance-in-series and Hermia's model were used to analyze the predominant fouling mechanism takes place on each membrane and how it affects the permeate flux. Experimental filtration time was similar to industrial procedures avoiding long filtration time with deep fouling, no recommended in factory.

Techniques such as chemical analysis, field scanning electron microscopy (FESEM), energy-dispersive spectrophotometry (EDS), attenuated total reflection-Fourier transform infrared (ATR-FTIR) spectroscopy and 3D fluorescence excitation-emission matrix (3DEEM) analysis were applied to understand which fraction of the DCScaused the reversible and irreversible fouling (Liu et al., 2003; Peiris et al., 2010; Peldszus et al., 2011; Poojamnong et al., 2020; Z. Wang et al., 2009).

\subsection{Materials and methods}

\subsubsection{Membrane filtration tests}

Dead-end filtration setup and experiments were performed according to the details in Section 0 .

- Dead-end filtration protocol

1. Pre-filtration: Filtration of $600 \mathrm{~mL}$ of the PMTE at 2.5 bar at $0.45 \mu \mathrm{m}$ to eliminate the larger suspended solids and higher molecular weight colloids.

2. First filtration step: Filtration of $250 \mathrm{~mL}$ of pre-filtrated raw feed at 2.0 bar to understand the flux decline and fouling resistance behavior. A new membrane was cut and used for each filtration test.

3. Cleaning by relaxation: The filtration cell was refilled with $15 \mathrm{~mL}$ of buffer solution ( $\mathrm{NaHCO} 31 \mathrm{mmol} / \mathrm{L}$ ) and stirred for $10 \mathrm{~min}$ at $100 \mathrm{rpm}$ to remove foulants by simulating membrane relaxation.

4. Second filtration step: Filtration of $40 \mathrm{~mL}$ of buffersolution at 2.0 bar to calculate flux recovery and membrane resistance after membrane relaxation (reversible fouling).

5. Cleaning by backwashing: The membrane was turned upside down, and filtration with $30 \mathrm{~mL}$ of buffer solution at 2.0 bar was carried out to remove foulants by performing a membrane backwash. 
6. Third filtration step: The membrane was put back in place, and the filtration of $30 \mathrm{~mL}$ buffer solution at 2.0 bar was performed to calculate the flux recovery.

\subsubsection{Ultrafiltration fouling models}

Permeate flux was gravimetrically measured at different time intervals, and the resistance-in-series model was used to study the role of differentfouling resistances that cause flux decline on the membrane as described by Darcy's Equation (Rushton et al., 1995):

$$
J_{p}=\frac{1}{A_{m} \rho} \frac{d m_{p}}{d t}=\frac{\Delta P}{\mu\left(R_{m}+R_{f}\right)}
$$

Equation 6-1

where,

$J_{p}$ is the permeate flux $\left(\mathrm{L} \cdot \mathrm{m}^{-2} \cdot \mathrm{h}^{-1}\right)$;

$A m$ is the effective membrane area $\left(\mathrm{m}^{-2}\right)$;

$m_{p}$ is the total mass of permeate $(\mathrm{kg})$;

$\rho$ is the volumetric mass density $\left(\mathrm{kg} \cdot \mathrm{m}^{-3}\right)$;

$\mathrm{t}$ is the filtration time $(\mathrm{s})$;

$\Delta P$ is transmembrane pressure drop $(\mathrm{Pa})$;

$\mu$ is the filtrate viscosity (Pa.s);

$R_{m}$ is the intrinsic membrane resistance $\left(\mathrm{m}^{-1}\right)$; and

$R_{f}$ is the fouling resistance $\left(\mathrm{m}^{-1}\right)$.

In dead-end filtration, and according to cake filtration model, the relationship between $R_{f}$ and the specific cake resistance $(\alpha)\left(\mathrm{m} \mathrm{kg}^{-1}\right)$ can be expressed by equation (Chang and Kim, 2005; Rushton et al., 1995) :

$$
R_{f}=\alpha M=\frac{\alpha * \mathrm{c} * V_{p}}{A}
$$

Equation 6-2

where,

$M$ is the cake mass of DCS $\left(m_{D C S}\right)$ per unit membrane area $\left(\mathrm{kg} \cdot \mathrm{m}^{-2}\right)$; and

$V_{p}$ is the permeate volume $\left(\mathrm{m}^{3}\right)$.

A mass balance equation is then used to obtain $c$, by the expression:

$$
c=\frac{m_{D C S}}{V_{p}}=\frac{\left(V_{0} c_{0}-V_{p} c_{p}\right)-V_{w} c_{w}}{V_{p}}
$$

Equation 6-3

where, 
$m_{D C S}$ is the cake mass of DCS $(\mathrm{kg})$;

$c$ is the mass of solids deposited on the cake layer per unit volume of filtrate $\left(\mathrm{kg} / \mathrm{m}^{3}\right)$;

$c_{0}$ and $c_{p}$ are the initial concentration in the feed and permeate concentration $\left(\mathrm{kg} / \mathrm{m}^{3}\right)$; and

$V_{0}$ and $V_{w}$ are the initial volume to be filtered and fluid volume retained in the cake $\left(\mathrm{m}^{3}\right)$, respectively.

Therefore, the classic method for determining $\alpha$, is to measure $V_{p}$ as a function of time, $\mathrm{t}$, during dead-end UF at constant pressure. Specific cake resistance can be calculate from the well-known expression derived using Equation 6-1 and Equation 6-2 and solving the follow integration (Foley, 2013):

$$
\int_{0}^{t} d t=\int_{0}^{V_{p}}\left(\frac{\mu * R_{m}}{\Delta P * A_{m}}+\frac{\mu * \alpha * c}{\Delta P * A_{m}^{2}} V_{p}\right) d V_{p}
$$

Equation 6-4

This integrated result can be rearranged to give the linear equation, where $\alpha$ can be calculated from the slope by simple plot of $\mathrm{t} / V_{f}=\mathrm{f}\left(V_{f}\right)$ at different applied pressures (Teychene et al., 2016).

In addiction, (Hermia, 1982) proposed a mathematical model Equation 6-5 denominated pore blocking fouling mechanism or Hermia's law to describe permeate flux decline phenomena, based on classical constant-pressure of dead-end filtration .

$$
\frac{\mathrm{d}^{2} \mathrm{t}}{\mathrm{dV}_{\mathrm{f}}^{2}}=\mathrm{K}\left(\frac{\mathrm{dt}}{\mathrm{dV}_{\mathrm{f}}}\right)^{\mathrm{m}}
$$

The exponent $m$ characterizes the type of blockage for each fouling mechanism, while the value of $K$ represents a constant fouling parameter that varied for each filtration processes. Hence, pore blocking during filtration can be divided in to four mechan isms: complete blocking $(m=2)$, intermediate blocking $(m=1)$, standard blocking $(m=$ $1.5)$, and cake layer formation $(m=0)$.

The analytical solutions of Equation 6-5 for each $m$ value as well as the linear forms of permeate flux models are shown in Table 6-1 (Bowen et al., 1995; Hermia, 1982; Vela et al., 2008). 
Table 6-1 - Summary of the fouling mechanisms by blocking models during dead-end filtration.

\begin{tabular}{cccccc}
\hline \hline $\begin{array}{c}\text { Fouling } \\
\text { mechanism }\end{array}$ & $m$ & $\begin{array}{c}\text { Fouling } \\
\text { concept }\end{array}$ & Fouling models & Linear forms & Eq. \\
\hline $\begin{array}{c}\text { Complete } \\
\text { blocking } \\
\text { Intermediate } \\
\text { blocking }\end{array}$ & 2 & Pore sealing & $\begin{array}{c}\text { Pore sealing } \\
\text { and membrane } \\
\text { deposition }\end{array}$ & $J_{p}=\frac{J_{0}}{\left(1+J_{0} K_{i b} t\right)}$ & $\frac{1}{J_{p}}=\frac{1}{J_{0}}+K_{i b} t$ \\
$\begin{array}{c}\text { Standard } \\
\text { blocking }\end{array}$ & 1.5 & $\begin{array}{c}\text { Pore walls } \\
\text { restricted }\end{array}$ & $J_{p}=\frac{\left.J_{0} t\right)}{\left(1+J_{0}{ }^{1 / 2} K_{s b} t\right)^{2}}$ & $\frac{1}{J_{p}{ }^{1 / 2}}=\frac{1}{J_{0}{ }^{1 / 2}}+K_{s b} t$ & $6-8$ \\
$\begin{array}{c}\text { Cake } \\
\text { formation }\end{array}$ & 0 & $\begin{array}{c}\text { Cake layers on } \\
\text { surface }\end{array}$ & $J_{p}=J_{0}\left(1+J_{0}{ }^{2} K_{c f} t\right)^{1 / 2}$ & $\frac{1}{J_{p}{ }^{2}}=\frac{1}{J_{0}{ }^{2}}+K_{c f} t$ & $6-9$ \\
\hline \hline
\end{tabular}

Furthermore, as described in the filtration protocol, at the end of the UF and after the washing steps, the flux decline and flux recovery for each MWCO was estimated using Equation 6-10 and Equation 6-11, sequentially:

$$
\text { Flux }_{\text {decline }}(\%)=\left(1-\frac{J_{p}}{J_{0}}\right) \times 100
$$

and

$$
\operatorname{Flux}_{\text {recovery }}(\%)=\frac{\mathrm{J}_{\mathrm{p}(\mathrm{AW})}}{\mathrm{J}_{0}} \times 100
$$

where,

$J_{0}$ is the initial permeate flux; and

$J_{p(A W)}$ is the permeate flux after washing.

\subsubsection{Mass Balance Analysis}

In order to determine the $m_{D C S}$, a mass balance was performed for the three different membranes ( $10 \mathrm{kDa}, 50 \mathrm{kDa}$ and $100 \mathrm{kDa}$ ) fouled by PMTE. The mass balance for the solution was calculated using the following equation:

$$
m_{\text {solution }}=C O T * V_{\text {solution }}
$$

Equation 6-12

where,

$m_{\text {solution }}$ is the mass of carbon in the solution ( $\left.\mathrm{mgC}\right)$; 
COT is the total organic carbon concentration measured in the solution ( $\mathrm{mgC} / \mathrm{L})$; and $V_{\text {solution }}$ is the volume of the solution (L).

After the washing steps (relaxation + backwashing), the TOC measurements were performed for each collected solution (feed, permeate, relaxation and backwashing) and the residual carbon mass on the membrane, termed irreversible carbon, was estimated using Equation 6-13.

$\mathrm{m}_{\text {DCS irreversible }}$ Equation 6-13

$$
=m_{\text {feed }}-m_{\text {permeate }}-m_{\text {relaxation }}-m_{\text {backwashing }}
$$

where,

$m_{D C \text { irreversible }}$ is the carbon mass remaining on the membrane or irreversible fouling (mgC);

$m_{f e e d}$ is the carbon mass in the feed solution (mgC);

$m_{\text {permeate }}$ is the carbon mass collected in the permeate $(\mathrm{mgC})$;

$m_{\text {relaxation }}$ is the carbon mass collected in the relaxation solution ( $\left.\mathrm{mgC}\right)$; and

$m_{\text {backwashing }}$ is the carbon mass collected in the backwashing solution (mgC).

The total organic matter (TOC) was measured using a TOC-VCSN Shimadzu Analyzer (Shimadzu, Japan). TOC samples were filtered through a $0.45 \mu \mathrm{m}$ filter prior to analysis.

\subsubsection{Identification and characterization of foulants}

6.3.4.1 Field emission scanning electron microscopy (FESEM) and energy dispersive spectrophotometry (EDS).

Micrographic imaging and elemental analysis of the fresh and fouled membranes were undertaken using FESEM in conjunction with EDS. FESEManalysis gives a qualitative assessment of the fouling formed on membrane surface. EDS determines the inorganic composition of the foulants. The dried membrane samples were attached to double sided adhesive carbon tape on an aluminum holder, and subsequently coated with platinum and observed by FESEM using a ZEISS, model: au riga compact. (Oxford Instruments, UK), at an accelerating voltage of $0.5-30 \mathrm{kV}$, and a working distance of $10 \mathrm{~mm}$ (Figure 6-2). Inorganic foulants on the membrane were determined by EDS (Aztec EDS with X-Max detector, Oxford Instruments, UK). The qualitative and 
quantitative analyses of EDS spectra were based on internal standards using Aztec software.

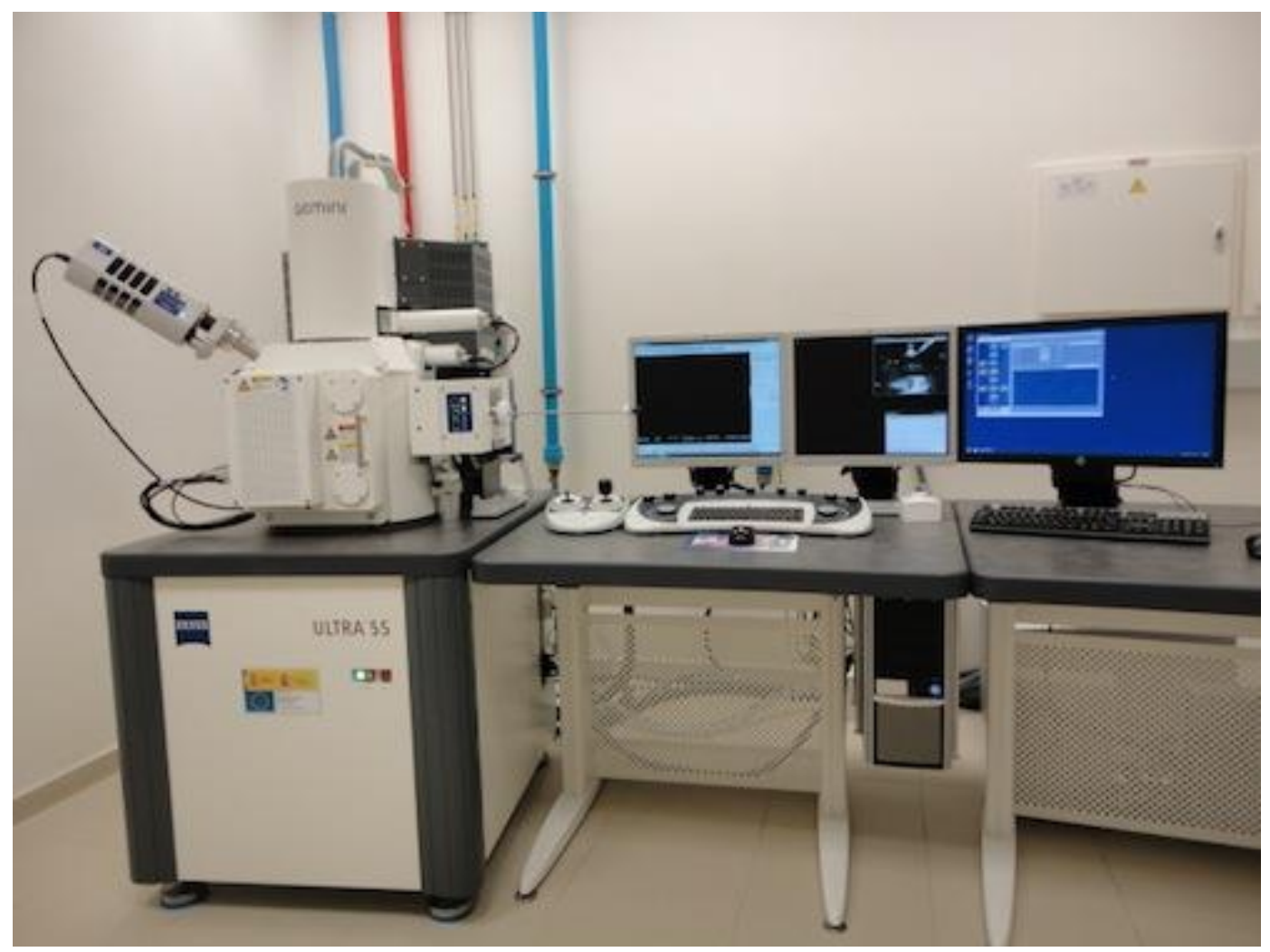

Figure 6-2 - Field Emission Scanning Electron Microscope (FESEM) (ZEISS ULTRA 55 model. Oxford Instruments, UK) used in the ISIRYM.

6.3.4.2 Attenuated total reflection-Fourier transform infrared (ATR-FTIR) spectroscopy analysis

The chemical structure of the clean, fouled and washed membrane samples (10 kDa, $50 \mathrm{kDa}$ and $100 \mathrm{kDa}$ ) were analyzed using an FTIR spectrometer in attenuated total reflectance (ATR) mode (Nicolet ${ }^{\mathrm{TM}}$ FT-IR spectrometers from Thermo Electron Corporation, with Universal ATR Sampling Attachment, Waltham, MA, USA) (Figure 6-3). The resolution of the ATR-FTIR apparatus was attuned to $4.0 \mathrm{~cm}^{-1}$, optical path difference velocity to $0.2 \mathrm{~cm} / \mathrm{s}$, and all the spectra were recorded within the range 4000- $400 \mathrm{~cm}^{-1}$. A ZnSe crystal (thallous bromide iodide) was used as an internal reflection element. The effective incident angle of the IR radiation was $45^{\circ}$. The background air spectrum was subtracted, and the spectra were offset corrected, normalized, and presented in absorbance. All the membranes were dried by slow evaporation in a desiccator overnight at room temperature prior to ART-FTIR 
characterization in order to minimize interference from water bands. Analysis was conducted at three random points on the membrane surface.

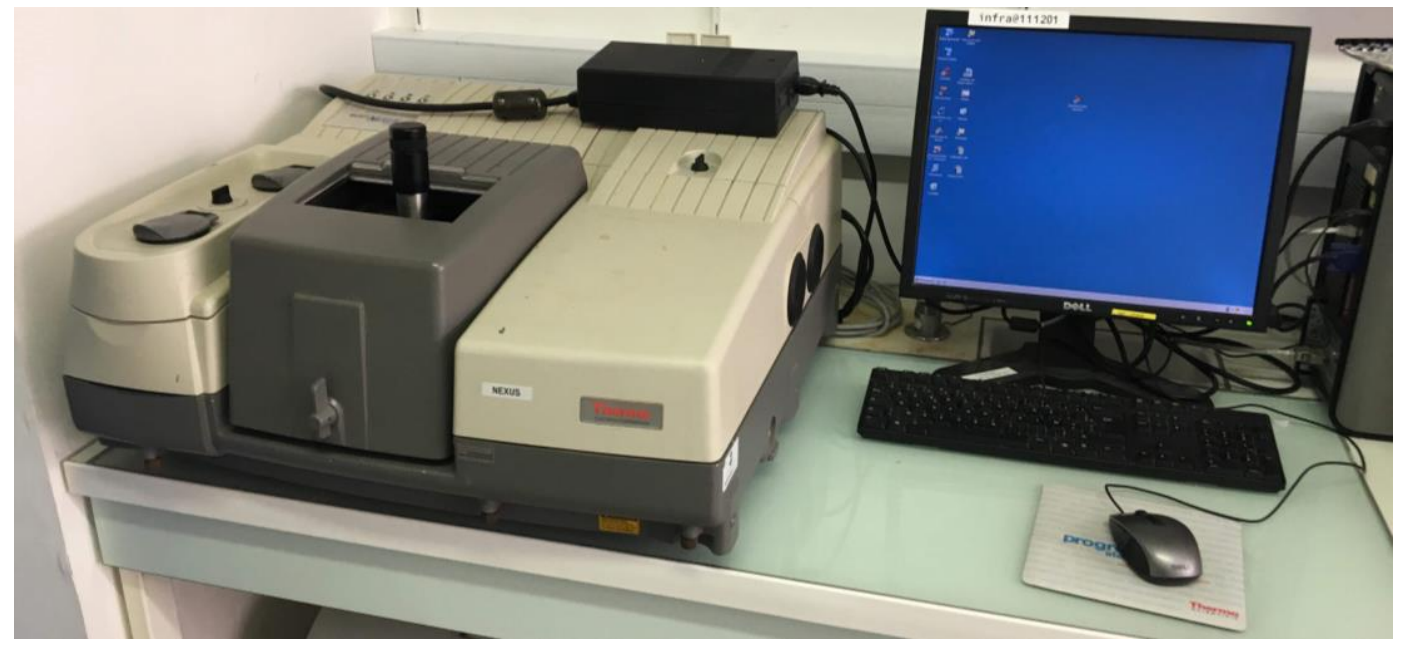

Figure 6-3 - FT-IR spectrometer with universal ATR Sampling Attachment (Thermo Electron Corporation, USA) used in the IEM.

\subsubsection{Foulant extraction}

The foulants were carefully extracted from the membranes using the following steps adapted from previous studies by Martínez de Peón et al.(2015) and Puro et al.(2011):

- The fouled membrane samples of $41.8 \mathrm{~cm}^{2}$ were dried in a desiccator at room temperature overnight and then cut into small pieces (approximately $1 \mathrm{~cm}^{2}$ ).

- Then, the membrane samples were placed into a $50 \mathrm{~mL}$ glass bottle and soaked in $20 \mathrm{~mL}$ acetone-water solution $(1: 9 \mathrm{v} / \mathrm{v})$ for $24 \mathrm{~h}$ at $20^{\circ} \mathrm{C}$ and completely mixed using a magnetic blender to ensure all the membrane pieces were in contact with the solvent.

- The extract solution, consisting of a mixing of DCS was filtrated through a syringe filter (membrane) with a mean pore size $0.22 \mu \mathrm{m}$.

- The filtrate was placed in a round-bottom flask and evaporated to dryness at a temperature of approximately $50-55^{\circ} \mathrm{C}$ under a vacuum pressure around 146 mbar for 30 min, using a Buchi rotavapor R-114 extraction system (Flawil, Switzerland) with a PC 600 dry pumping chemistry vacuum u nit (Wertheim, Germany). The extraction setup is shown in Figure 6-4.

- Finally, the foulant was re-dissolved in $3 \mathrm{~mL}$ of the acetone-water solution (1:9 $\mathrm{v} / \mathrm{v}$ ), and then subjected to further 3DEEM and other analysis. 


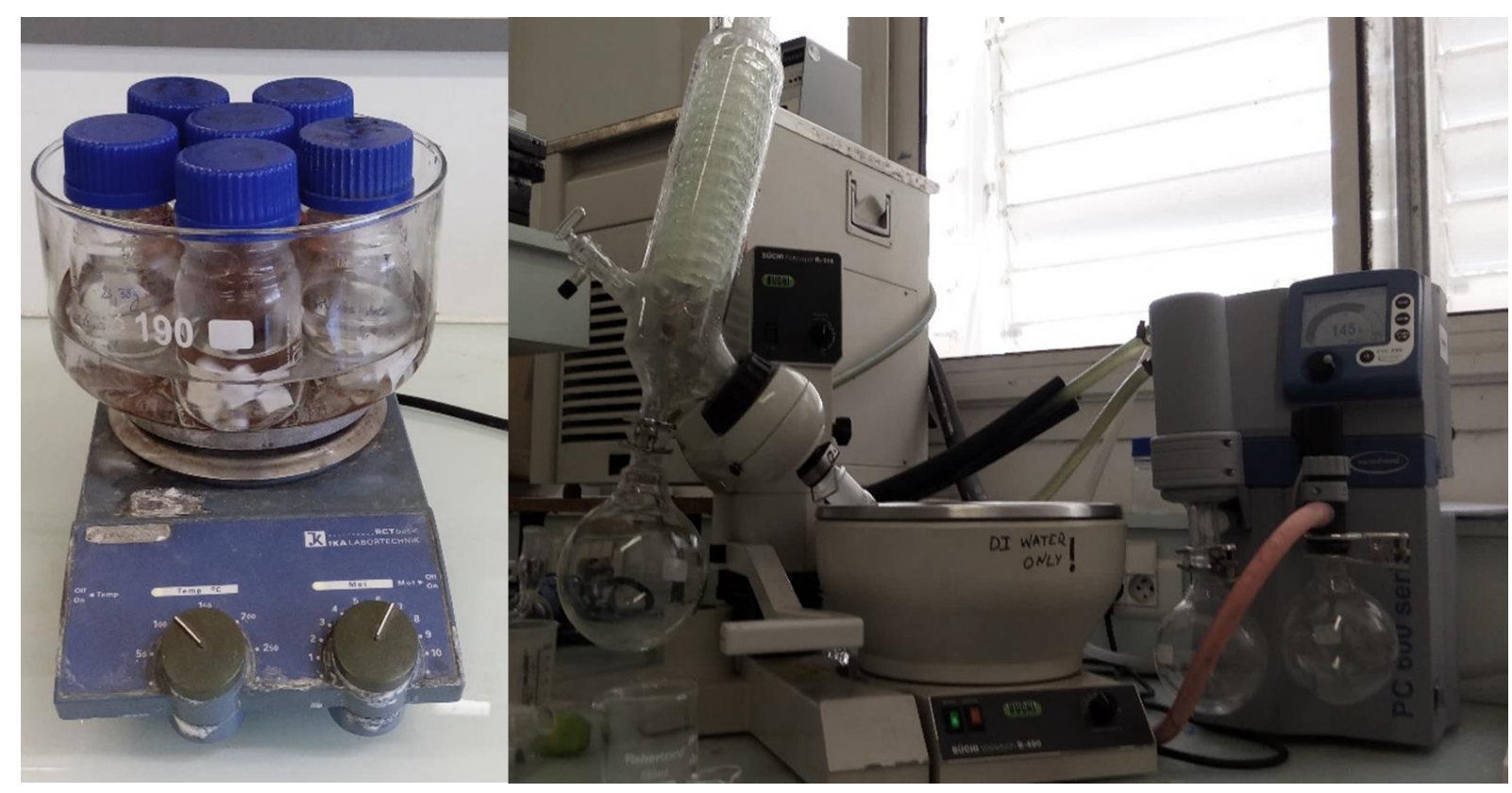

Figure 6-4 - Rotavapor extraction system and vacuum unit used to foulants extraction, used in the IEM.

\subsubsection{3DEEM fluorescence spectra analysis}

3DEEM analyses were performed using a Perkin-Elmer, LS-55 fluorescence spectrometer (PerkinEImer Inc., Waltham, MA, USA) (Figu re 6-5), at room temperature $\left(22.0 \pm 2{ }^{\circ} \mathrm{C}\right)$. In this study, 3DEEM spectra were collected with the scanning excitation wavelength $\left(\lambda_{e x}\right)$ set at 200-500 nm and the emission wavelength $\left(\lambda_{e m}\right)$ from $280 \mathrm{~nm}$ to $600 \mathrm{~nm}$. Scan speed was set at $1000 \mathrm{~nm} / \mathrm{min}$ and the increment to $2 \mathrm{~nm}$, while the slit width was set at $10 \mathrm{~nm}$ in excitation and emission (C. Jacquin et al., 2017 and 2018; W. Chen et al.,2003b).

To avoid Raman scatter by the particles (Tian et al., 2015), fluorescence measurements were done on pre-filtered $(0.45 \mu \mathrm{m})$ at room temperature $\left(22 \pm 2{ }^{\circ} \mathrm{C}\right)$. 


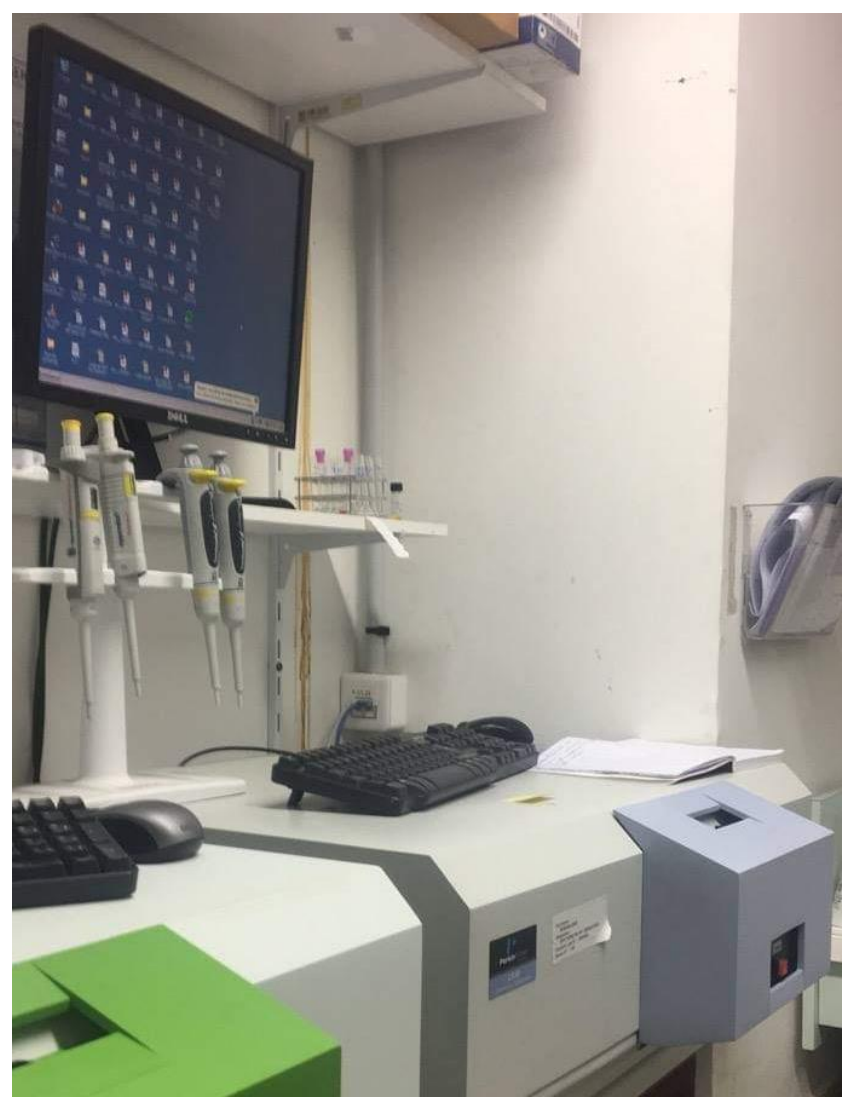

Figure 6-5 - Photograph of Perkin-Elmer, LS-55 fluorescence spectrometer (PerkinEImer, USA), used in the IEM.

To limit overlapping signals and avoid the inner filter effect, the samples were diluted with pure water (Mili-Q, Millipore, Merck KGaA, Darmstadt, Germany) with a dilution ratio determined after measurements at successive dilution ratios (C. Jacquin et al., 2018; Carstea et al., 2016; Shao et al., 2014). All spectra were Raman normalized using a Mili-Q water blank (the Milli-Q water spectrum was subtracted from the 3DEEM spectrum for each sample) following the procedure described by Goletz et al. (2011) and Peiris et al. (2010).

Therefore, after Raman normalization, the fluorescence intensity in Raman units (R.U) was assessed (Park and Snyder, 2018). As described in a previous study carried out by W. Chen et al. (2003b) the spectra were divided into five areas (Table 6-2). 
Table 6-2 - Characteristics of the associated fluorophores detected by 3DEEM according to W. Chen et al. (2003b).

\begin{tabular}{|c|c|c|c|}
\hline Region & Associated fluorophores & $\begin{array}{c}\text { Excitation and Emission } \\
\text { wavelengths }\end{array}$ & Abbreviation \\
\hline Region I & $\begin{array}{c}\text { Aromatic protein I-like } \\
\text { (tyrosine) }\end{array}$ & $\begin{array}{l}E x=200-250 \mathrm{~nm} \\
E m=280-330 \mathrm{~nm}\end{array}$ & Prot1 - likeздеEM \\
\hline Region II & $\begin{array}{l}\text { Aromatic protein Il-like } \\
\qquad\left(\mathrm{BOD}_{5}\right)\end{array}$ & $\begin{array}{l}E x=200-250 \mathrm{~nm} \\
E m=330-380 \mathrm{~nm}\end{array}$ & Prot2 - likeздEEM \\
\hline Region III & Fulvic acid-like & $\begin{array}{l}E x=200-250 \mathrm{~nm} \\
E m=380-600 \mathrm{~nm}\end{array}$ & FA - likeзDEEM \\
\hline Region IV & $\begin{array}{c}\text { Soluble microbial product } \\
\text { (tryptophane) }\end{array}$ & $\begin{array}{l}E x=250-350 \mathrm{~nm} \\
E m=280-380 \mathrm{~nm}\end{array}$ & SMP - likeздеEM \\
\hline Region V & Humic acid-like molecules & $\begin{array}{l}E x=250-500 n m \\
E m=380-500 n m\end{array}$ & HA - likeзDEEM \\
\hline
\end{tabular}

DCS fractions and consequently 3DEEM data were analyzed quantitatively using volume of fluorescence $\Phi$ (i) (R.U.nm²) parameter from the Fluorescence Regional Integration (FRI) method originally proposed by W. Chen et al. (2003b). This methodology permits all the fluorescent compounds detected within each fluorophore region (Table 6-2) to be considered. Fluorescence volumes were calculated from the corrected matrix, using the following Equation 6-14 originally proposed by W. Chen et al. (2003b).

$$
\Phi(\mathrm{i})=M F(i) \sum_{e x} \sum_{e m} \mathrm{I}_{\text {final }}\left(\lambda_{e x}, \lambda_{e m}\right) \Delta \lambda_{e x} \Delta \lambda_{e m}
$$

where,

$M F(i)$ is the area multiplication factor;

$I_{\text {final }}\left(\lambda_{\text {ex }}, \lambda_{\text {em }}\right)$ is the final fluorescence intensity at each excitation - emission wavelength in (R.U); and

$\Phi(i)$ normalization was necessary to compare values from different regions of the 3DEEM response.

To make it, $M F(i)$ was calculated using Equation 6-15 (Jacquin et al., 2017): 


$$
M F(i)=\frac{\operatorname{Area}_{\text {tot }(3 D E E M)}}{\operatorname{Area}_{\text {region }(i)}}
$$

where,

$A r e a_{\text {tot (3DEEM) }}$ is the total spectrum area $\left(\mathrm{nm}^{2}\right)$; and

$\operatorname{Area}_{\text {region }(i)}=$ is the specific region area (i) $\left(\mathrm{nm}^{2}\right)$.

\subsection{Results and discussion}

6.4.1 Analysis of the influence of membrane MWCO on permeate flux and fouling mechanism

One of the mainly goals of the filtration experiments was to understand the effects of MWCO on membrane fouling behavior. As shown in Figure 6-6, during the UF in deadend mode at constant pressure, the initial permeate flux increased with an increase in MWCO due to the direct relationship between permeate flux and nominal membrane pore sizes. Thus, when comparing the three membranes used in the filtration experiments, the flux was higherfor membranes with a larger MWCO.

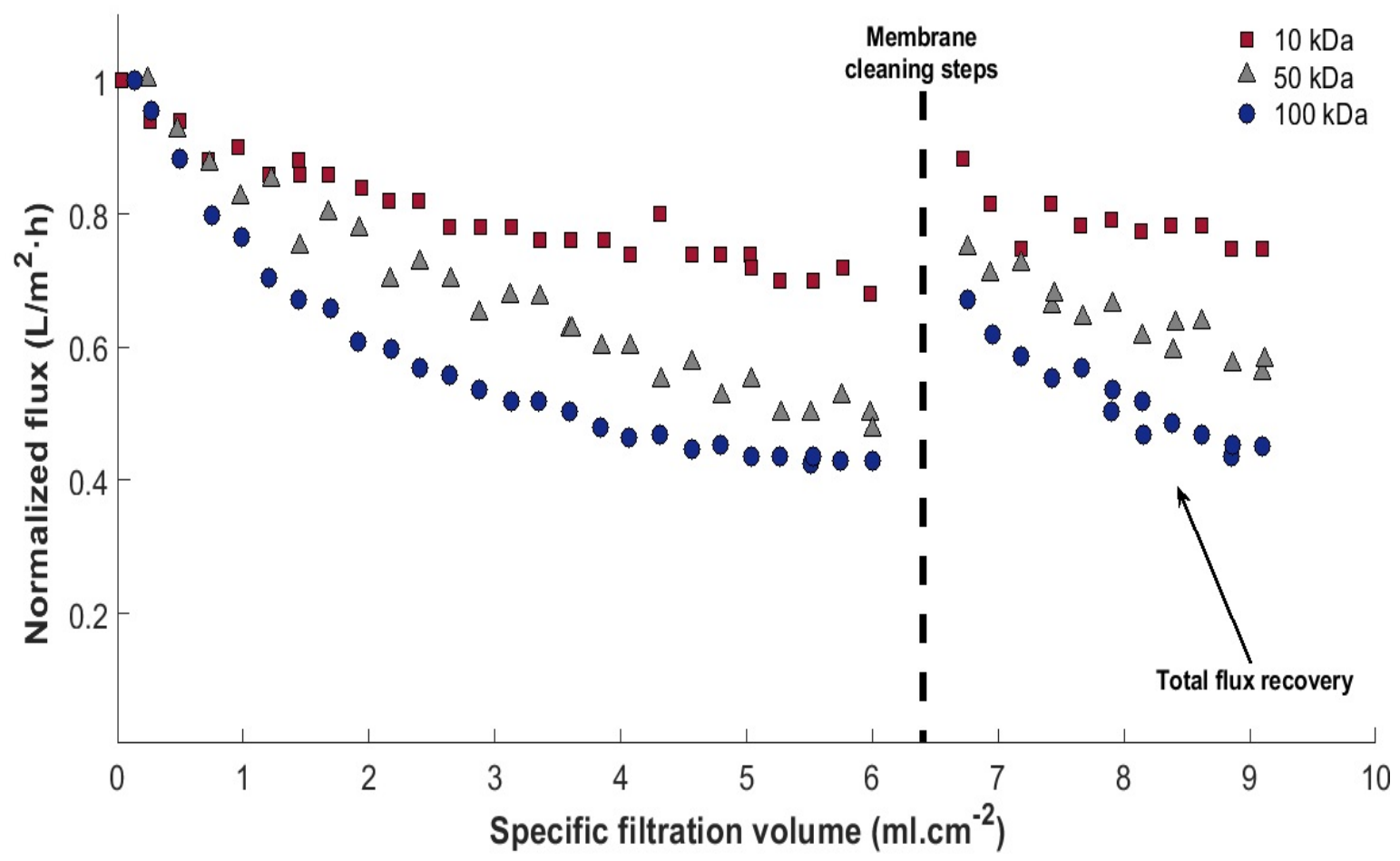

Figure 6-6 - Normalized flux vs. specific filtration volume, during the filtration of PMTE using $10 \mathrm{kDa}, 50 \mathrm{kDa}$ and $100 \mathrm{kDa}$ UF-PES membranes. The applied TMP was $2.0 \mathrm{bar}$, at room temperature and TOC concentration of the feed solution about $78.0 \pm 2.5 \mathrm{mg} \cdot \mathrm{L}^{-1}$. 
The initial permeate flux was found for the $100 \mathrm{kDa}$ membrane with $J_{0}=102.77 \mathrm{~L} / \mathrm{m}^{2} / \mathrm{h}$ followed by the $50 \mathrm{kDa}$ membrane with $J_{0}=73.49 \mathrm{~L} / \mathrm{m}^{2} / \mathrm{h}$ and then by $10 \mathrm{kDa}$ membrane with $J_{0}=28.70 \mathrm{~L} / \mathrm{m}^{2} / \mathrm{h}$. However, it can be seen that even though the 100 kDa membrane presented the greatest initial flux, it declined very quickly and mainly during the first few minutes of the filtration, which can be attributed to the deposition of the DCS and adsorption into the membrane pores, followed by cake formation. Therefore, after filtration of $6.0 \mathrm{ml} . \mathrm{m}^{-2}$ (i.e $250 \pm 0.5 \mathrm{ml}$ of PMTE), it was noted that for the lowest MWCO (10 kDa), the flux decline was smaller and slower compared to the larger MWCO (50 kDa and then $100 \mathrm{kDa})$. The highest reduction in the permeate flux was $56.98 \%$ for the $100 \mathrm{kDa}$ membrane followed by $52.50 \%$ for the $50 \mathrm{kDa}$ membrane and $32.50 \%$ for the $10 \mathrm{kDa}$ membrane.

A very significant membrane flux recovery was observed immediately after cleaning for all MWCO (dead-end filtration protocol) (see Figure 6-6), indicating a high effectiveness in removing the cake layer formed by the colloids associated with reversible fouling. The membrane performance and flux recoveries obtained from the different MWCO are reported in Table 6-3.

Table 6-3 - Permeate flux, flux reduction and total flux recovery after cleaning steps (relaxation and backwashing) from different MWCO membranes.

\begin{tabular}{ccccc}
\hline \hline MWCO & $\begin{array}{c}\text { Permeate flux on } \\
\text { clean membrane } \\
\left(\text { L. m }^{-2} \cdot \mathrm{h}^{-1}\right)\end{array}$ & $\begin{array}{c}\text { Flux reduction } \\
(\%)\end{array}$ & $\begin{array}{c}\text { Permeate flux after } \\
\text { cleaning step } \\
\left(\text { L. m }{ }^{-2} \cdot \mathrm{h}^{-1}\right)\end{array}$ & $\begin{array}{c}\text { Total flux recovery } \\
(\%)\end{array}$ \\
\hline \hline $10 \mathrm{kDa}$ & $28.70 \pm 1.23$ & 32.00 & $25.38 \pm 0.49$ & 88.40 \\
$50 \mathrm{kDa}$ & $73.49 \pm 1.17$ & 52.50 & $54.89 \pm 1.04$ & 74.69 \\
$100 \mathrm{kDa}$ & $102.78 \pm 2.65$ & 56.98 & $68.90 \pm 3.00$ & 67.03 \\
\hline \hline
\end{tabular}

6.4.2 Resistance-in-series and pore blocking model analysis

In Figure 6-7 the results of filtration experiments for all UF membranes tested, are presented on the plot of $t / V_{f}$ vs. $V_{f}$, which should be linear when the fouling mechanism is the cake filtration by Equation 6-4. The resistance-in-series model (Equation 6-1 and Equation 6-2 was used to analyze membrane resistances that lead to flux decline during the UF process. As shown in Figure 6-7, the fouling resistance $\left(R_{f}\right)$ increased throughout the filtration period, due to pore blocking du ring the earlier stages, and cake growth on the membrane surface during the later stages of UF and $R_{f}$ was highest for the largest MWCO (i.e $100 \mathrm{kDa}$ ), which indicates that more cohesive cake layers form 
on the membranes and, consequently, fouling becomes more irreversible. These results are consistent with those presented by Lee,(2013).
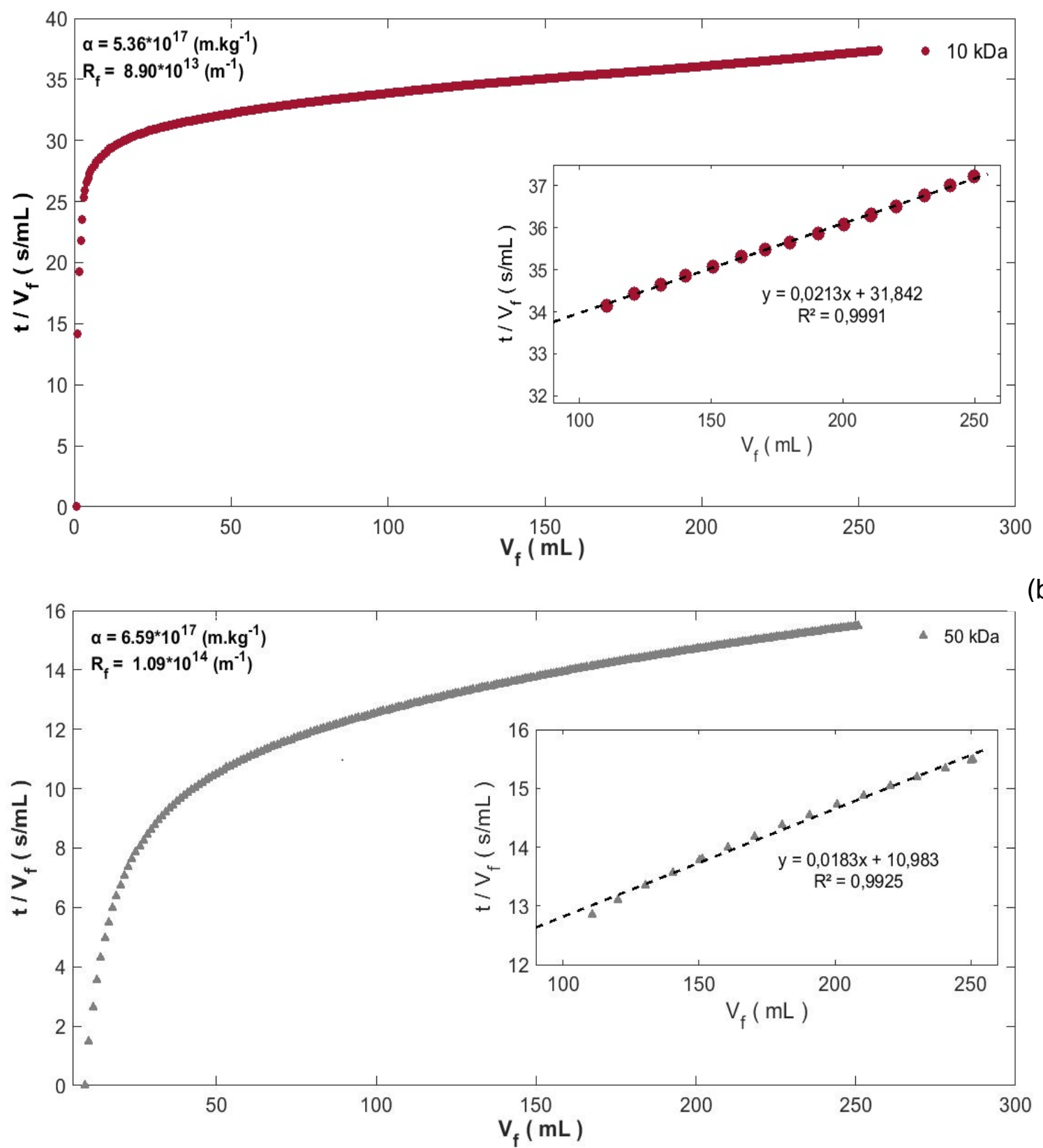

(b) 


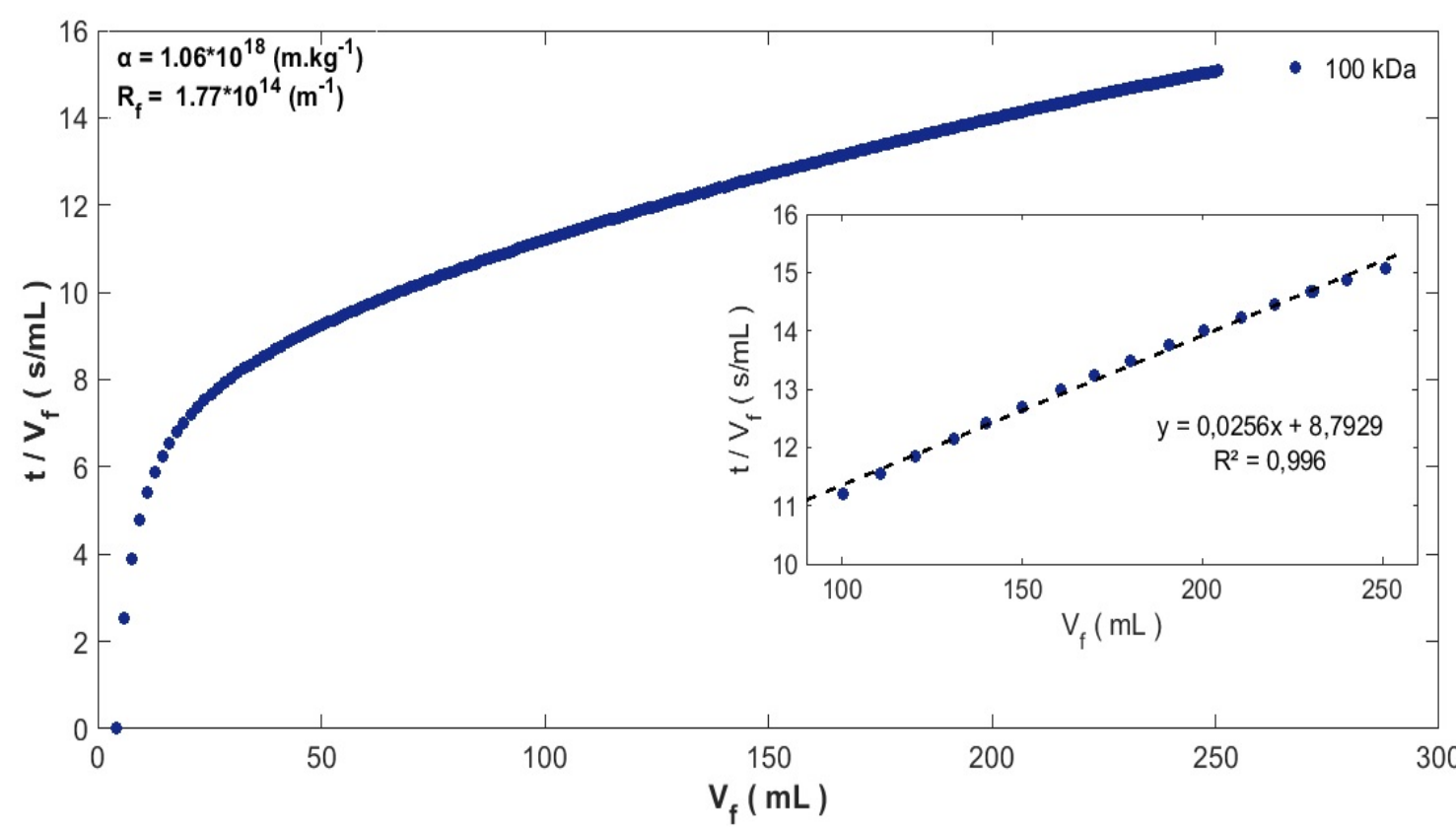

(c)

Figure 6-7 - Specific resistance $(\alpha)$ and fouling resistance $\left(R_{f}\right)$ calculated using the resistance-in series-model for (a) 10 kDa MWCO, (b) 50 kDa MWCO and (c) 100 kDa MWCO membranes.

The highest values for $\mathrm{R}_{\mathrm{f}}$ were obtained at the highest mass of DCS $\left(\mathrm{m}_{\mathrm{DCS}}\right)$ deposited on the membrane area per unit of permeate volume due to a more compact cake structure on the membrane surface. Thus, $\mathrm{R}_{\mathrm{f}}$ for the $10 \mathrm{kDa}$ MWCO membrane it was around $8.90 \times 10^{13} \mathrm{~m}^{-1}$, for the $50 \mathrm{kDa}$ MWCO it was $1.09 \times 10^{14} \mathrm{~m}^{-1}$ and for the $100 \mathrm{kDa}$ MWCO it was $1.77 \times 10^{14} \mathrm{~m}^{-1}$.

It is worth mentioning that the nonlinearity of the curves $t / V_{f}$ vs. $V_{f}$ during the early stages of experiments implies that pore blocking preceded the cake resistance in early stage of filtration.

Therefore, pore blocking mechanisms were identified with a method based on a simple parameter estimation in nonlinear regression models (Table 6-1). Table 6-4 presented the values of optimized parameters $K_{C b}, K_{i b}, K_{s b}$ and $K_{c f}$ according to 6-6 - 6-9, respectively, the comparison of experimental average permeate flux and the predicted average flux (Figure 6-8), and the corresponding correlation coefficients $\left(\mathrm{R}^{2}\right)$. 
Table 6-4 - Values of pore blocking parameters, comparison between the experimental and predicted average permeate flux and the model fitting accuracy $\left(R^{2}\right)$.

\begin{tabular}{cccccc}
\hline \hline Models & $\begin{array}{c}\text { MWCO } \\
(\mathrm{kDa})\end{array}$ & $\begin{array}{c}\text { Constantfouling } \\
(K)\end{array}$ & $\begin{array}{c}\bar{J}_{p(\text { exp })} \\
\left(\mathrm{L} . \mathrm{m}^{-2} . \mathrm{h}^{-1}\right)\end{array}$ & $\begin{array}{c}\bar{J}_{p(\text { pred })} \\
\left(\mathrm{L} . \mathrm{m}^{-2} . \mathrm{h}^{-1}\right)\end{array}$ & $\mathrm{R}^{2}$ \\
\hline \hline Cake & 10 & $2.06 \times 10^{6}$ & 23.071 & 23.277 & 0.878 \\
filtration & 50 & $1.20 \times 10^{6}$ & 54.314 & 54.582 & 0.949 \\
$\mathrm{~m}=0$ & 100 & $1.99 \times 10^{6}$ & 59.961 & 59.939 & 0.969 \\
\hline \hline Intermediate & 10 & 6.94 & 23.071 & 23.376 & 0.824 \\
blocking & 50 & 9.76 & 54.314 & 54.928 & 0.890 \\
$\mathrm{~m}=1$ & 100 & 18.61 & 59.961 & 60.628 & 0.875 \\
\hline \hline Standard & 10 & $9.0 \times 10^{-3}$ & 23.071 & 23.438 & 0.789 \\
blocking & 50 & $19.6 \times 10^{-3}$ & 54.314 & 55.177 & 0.846 \\
m=1.5 & 100 & $39.7 \times 10^{-3}$ & 59.961 & 61.375 & 0.788 \\
\hline \hline Complete & 10 & $4.66 \times 10^{-5}$ & 23.071 & 23.509 & 0.749 \\
blocking & 50 & $1.56 \times 10^{-4}$ & 54.314 & 55.494 & 0.790 \\
m=2 & 100 & $3.36 \times 10^{-4}$ & 59.961 & 62.569 & 0.662 \\
\hline \hline
\end{tabular}

* $K$ unit depending on the parameter $m . K_{c b}\left(\mathrm{~s}^{-1}\right) ; K_{i b}\left(\mathrm{~m}^{-1}\right) ; K_{s b}\left(\mathrm{~m}^{-1 / 2} \cdot \mathrm{s}^{-1 / 2}\right)$ and $K_{c f}\left(\mathrm{~s} / \mathrm{m}^{2}\right)$.

As can be seen from Table 6-4, for all MWCO, cake formation has the closest values of experimental permeate flux and has higher $\mathrm{R}^{2}$ values, between 0.878 (10kDa) and $0.969(100 \mathrm{kDa})$, confirming that the cake layer formation became the most dominant mechanism for permeate flux decline during UF of the PMTE. However, intermediate pore blocking played an important role in the fouling of membranes in this current study (see $\mathrm{R}^{2}$ in Table 6-4). It indicates thatmajority of foulants (macromolecules and colloids such as proteins and polysaccharides) in feed solution (Miao et al., 2012) have bigger size than membrane pores. Those particles could not enter the membrane pores, are retained on the membrane surface and consequently allows the formation and compression of the cake layer. 

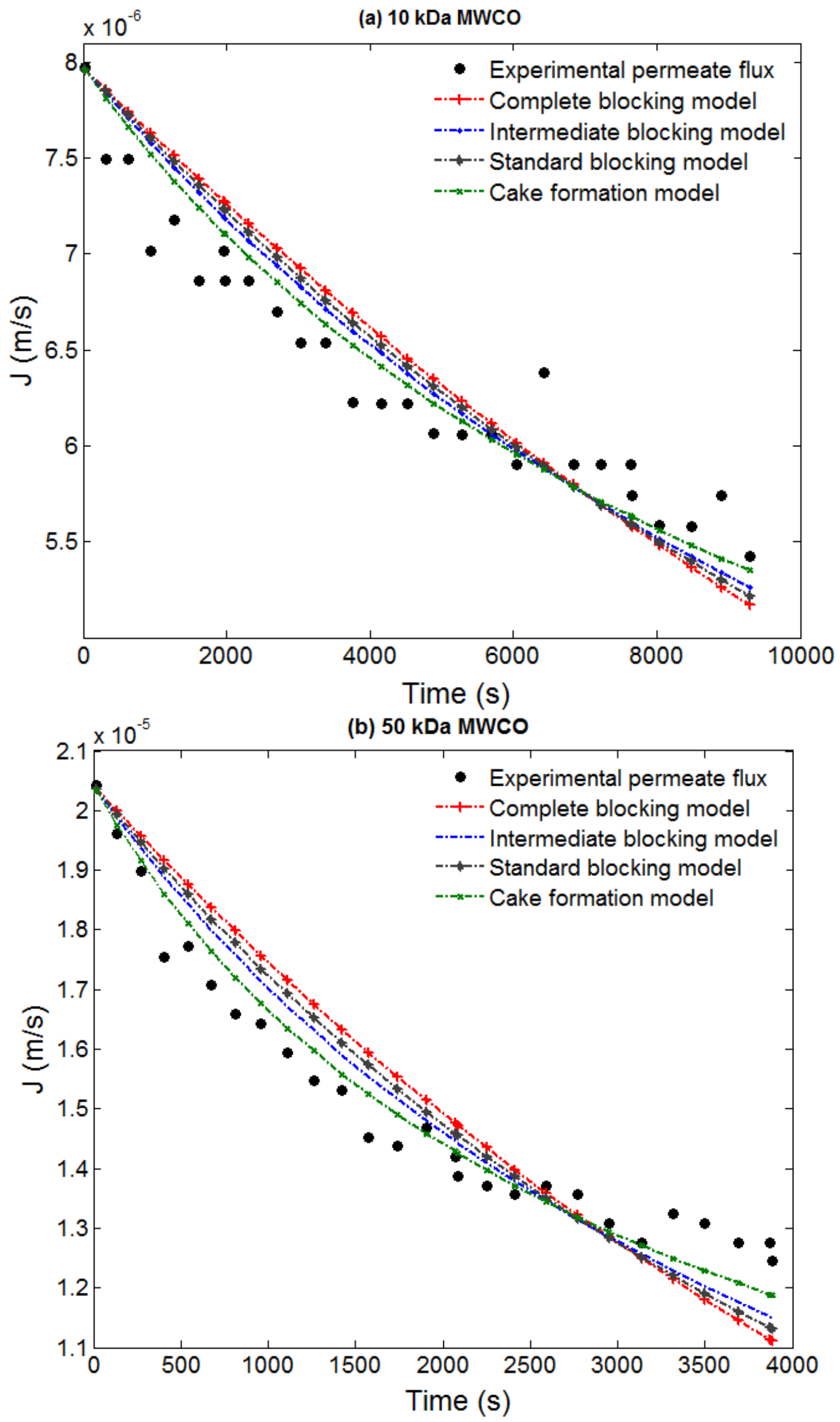


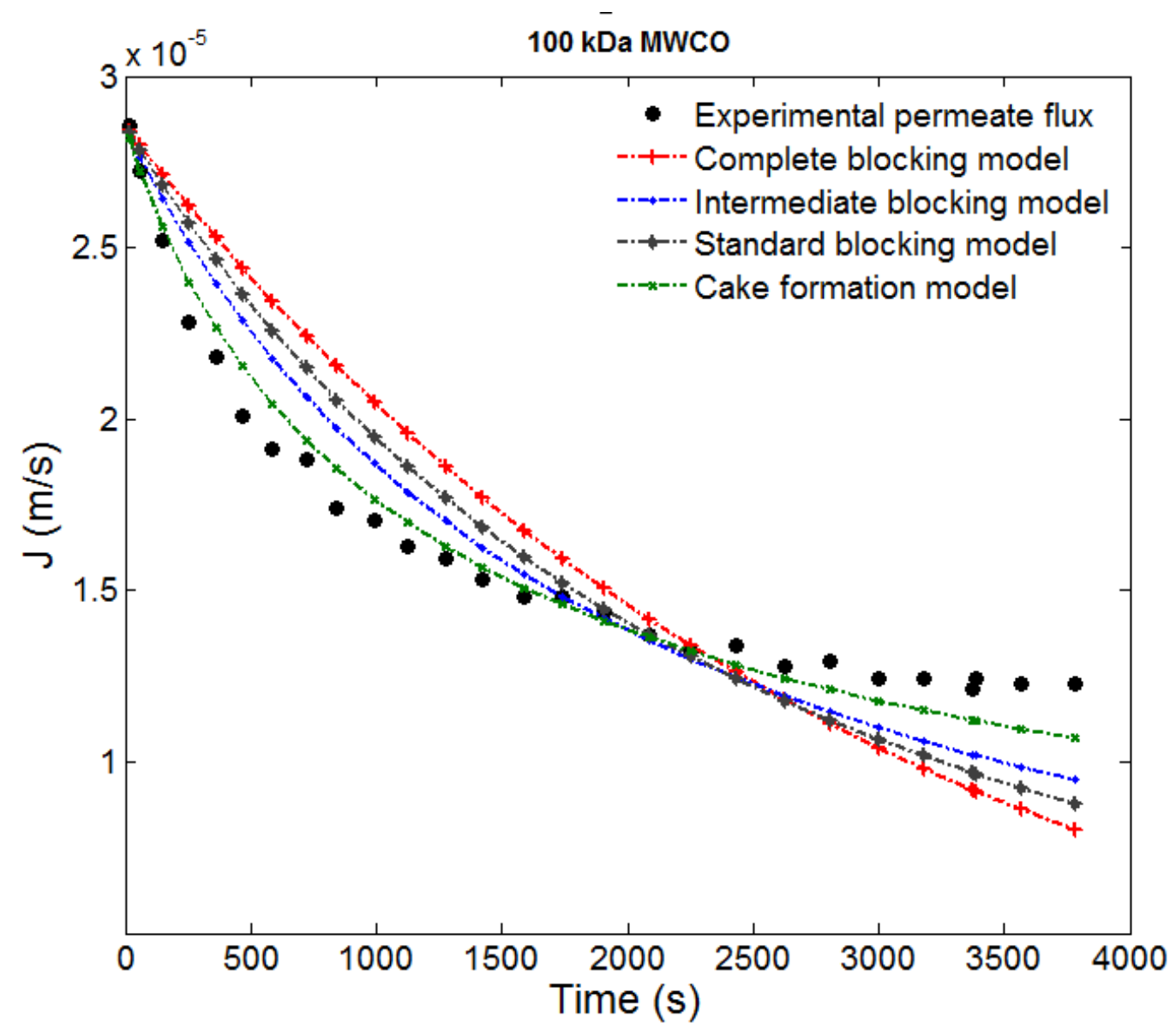

Figure 6-8 - Comparison between experimental average permeate flux and predicted average flux fitted by dead-end pore blocking models Equation 66 - Equation 6 9:(a) $10 \mathrm{kDa}$ MWCO, (b) 50 kDa MWCO and (c) 100 kDa MWCO membranes. 


\subsubsection{Mass balance analysis}

The mass balance and TOC measurements were used to evaluate the irreversible carbon (fouling) deposited and/or adsorbed onto the membrane (Figure 6-9) after the cleaning steps described in dead-end filtration protocol.

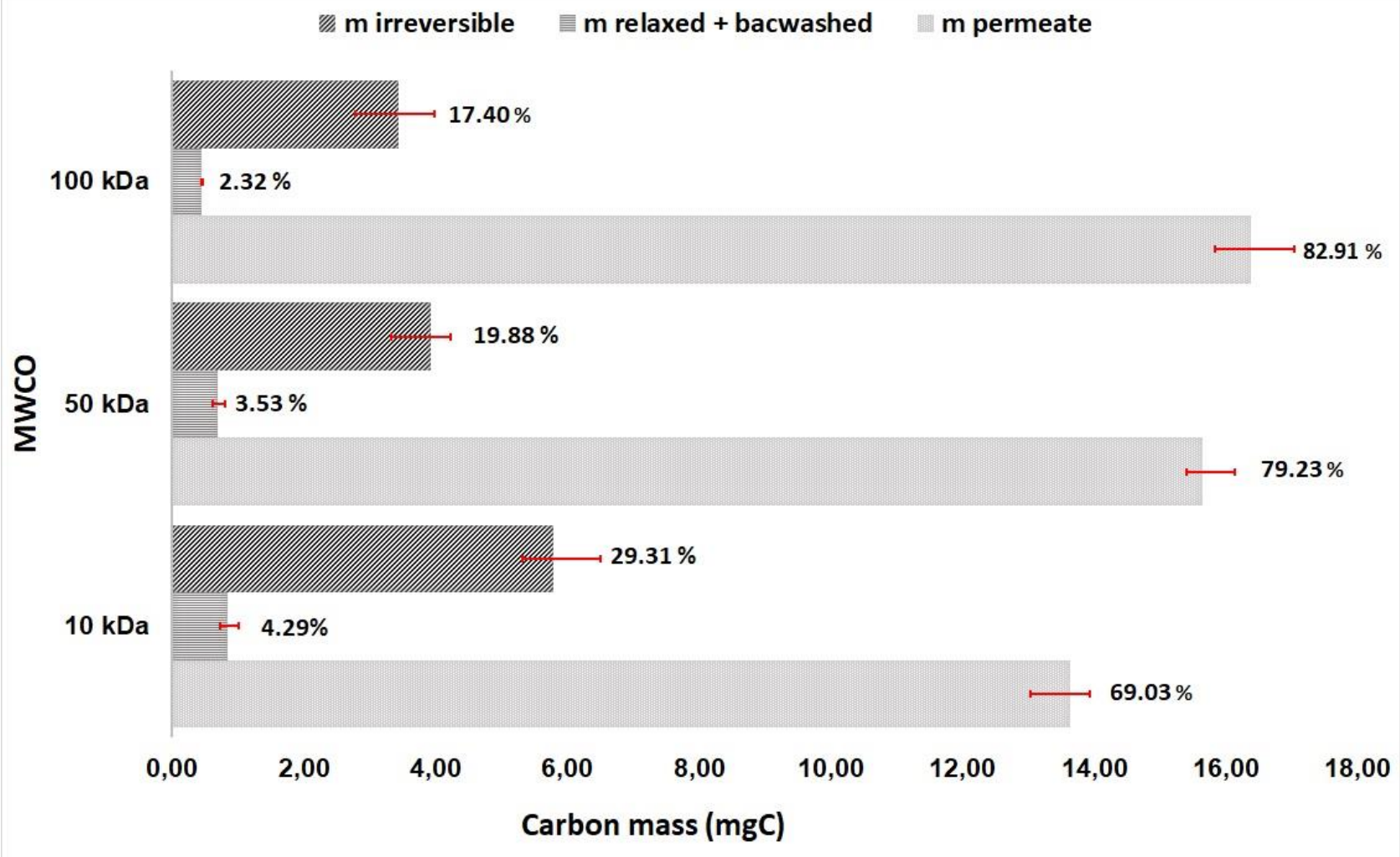

Figure 6-9 - Carbon mass balances during UF for different MWCO, $\mathrm{m}_{\text {feed }}=19.76 \pm 0.5 \mathrm{mg}$.C.

It can be observed due the DCS complexity and their large size distribution an interaction between the particles, colloids and dissolved matter presented in the feed solution with MWCO, thus membrane pore size played a key role in the organic carbon retained on the membrane, consequently the irreversible fouling in the mass balance increased with decreasing MWCO as present in Figure 6-9, showing a disagreement with the results obtained in the membrane cleaning efficiency and flux recovery results presented in Table 6-3. According to the calculated by Equation 6-13, approximately 5.79 mg.C, 3.93 mg.C and 3.44 mg.C remaining on the membranes (10 kDa, $50 \mathrm{kDa}$ and $100 \mathrm{kDa}$, respectively) as carbon mass irreversible ( $\left.\mathrm{m}_{\mathrm{DCS} \text { irreversible }}\right)$.

6.4.4 Aromatic carbon (SUVA) removal by UF membrane In this study the specific UV absorbance (SUVA) and TOC were used to assess the aromatic carbon and humic substance (HS) content of the DCS in the feed solution 
(PMTE) and permeates. Table 6-5 Shows the SUVA values for the PMTE and the permeates at different MWCO. It can be seen, that the SUVA values barely decrease in the permeates as compared with the feed solution. The mean SUVA value of the PMTE was $1.11 \pm 0.03 \mathrm{~L} / \mathrm{mg} / \mathrm{m}$ and this implies a low hydrophobicity and low molecular weight of the DCS in the effluent.

Table 6-5 - Aromatic carbon (SUVA) in the PMTE and permeates, at 2.0 bar and different MWCO.

\begin{tabular}{ccccc}
\hline \hline & \multicolumn{3}{c}{ Permeates } & \\
& Raw PMTE & $10 \mathrm{kDa}$ & $50 \mathrm{kDa}$ & $100 \mathrm{kDa}$ \\
\cline { 2 - 5 } $\mathrm{UV}_{254}\left(\mathrm{~cm}^{-1}\right)$ & $0.943 \pm 0.012$ & $0.518 \pm 0.021$ & $0.582 \pm 0.010$ & $0.648 \pm 0.014$ \\
$\mathrm{TOC}\left(\mathrm{mg} \cdot \mathrm{L}^{-1}\right)$ & $80.00 \pm 2.46$ & $50.60 \pm 1.72$ & $61.21 \pm 1.45$ & $63.88 \pm 1.35$ \\
Reduction of COT & -- & $33.92 \%$ & $23.48 \%$ & $20.14 \%$ \\
SUVA $\left(\mathrm{L} \cdot \mathrm{mg}^{-1} \cdot \mathrm{m}^{-1}\right)$ & $1.114 \pm 0.030$ & $1.010 \pm 0.045$ & $0.956 \pm 0.024$ & $0.993 \pm 0.026$ \\
\hline \hline
\end{tabular}

As shown in Table 6-5, the mean SUVA values (feed and permeates) were relatively low (less than $3 \mathrm{~L} / \mathrm{mg} / \mathrm{m}$ ), which suggest that most of the organic carbon material content in the PMTE consists mainly of hydrophilic components with low aromaticity and with low rejection by UF membranes. In addition, the TOC removal efficiencies of the $10 \mathrm{kDa}, 50 \mathrm{kDa}$ and $100 \mathrm{kDa}$ MWCO were relatively low (23.93\%, 18.33\% and $12.24 \%$, respectively).

\subsubsection{DEEM fluorescence analysis}

In this study, a 3D fluorescence excitation-emission matrix was used to identify and characterize the organic matter in the PMTE and permeates and on the fouled membranes. The 3DEEM fluorescence spectra for the PMTE and permeates for 10$\mathrm{kDa}, 50-\mathrm{kDa}$ and 100-kDa PES membranes are shown in Figure 6-10. In addition, as described in section 2.9, the spectra were analyzed into the five areas defined by $\mathrm{W}$. Chen et al. (2003b). 

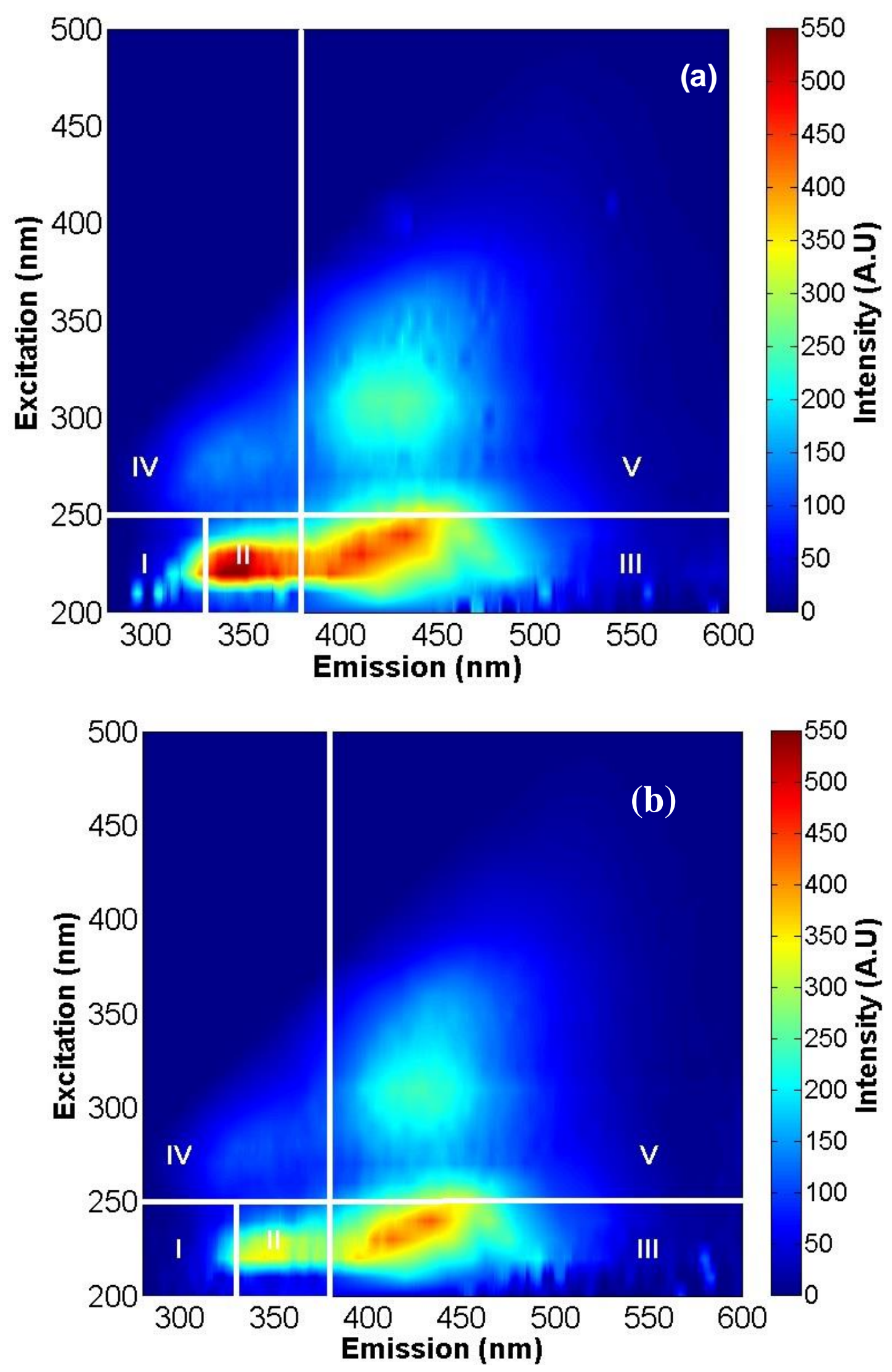

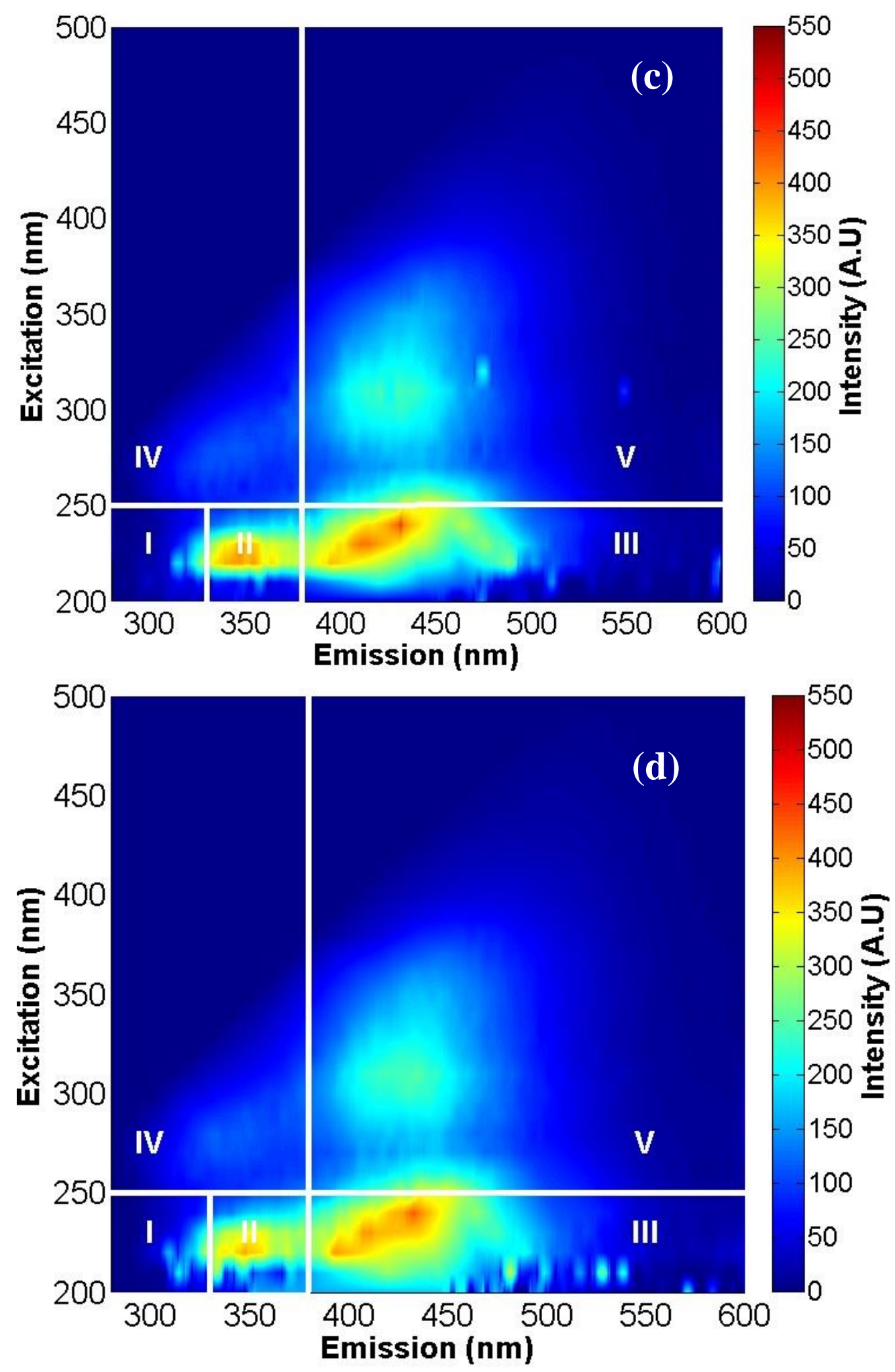

Figure 6-10 - 3DEEM fluorescence spectra for (a) feed solution (prefiltered with $0.45 \mu \mathrm{m}$ filter); (b) permeate $10 \mathrm{kDa}$; (c) permeate $50 \mathrm{kDa}$; and (d) permeate $100 \mathrm{kDa}$. Region I and II = aromatic protein-like substances I and II respectively; Region III = fulvic acid-like substances; Region IV = soluble microbial by-products; Region V = humic acid-like substances. 
In Figure 6-10, it can easily be seen from the qualitative analyses that aromatic protein like substance II and fulvic acid-like substances are predominant in the feed solution. In addition, after dead-end UF at 2.0 bar, a decrease in the percentage fluorescence intensity in all membranes was observed, mainly in regions II, III, and IV. This suggests that a significant proportion of the fluorescent protein-like substances (high MW), including BOD5, tryptophan, and extracellular polymeric substances (EPS), were removed in the permeates. Moreover, it can be seen that the decrease in the fluorophore compounds' intensity was higher in the lower MWCO (10 kDa) due to the difference between the substances' molecular weight (MW) and the membrane pore size.

In addition, the 3DEEM data were analyzed quantitatively using the volume of fluorescence $\Phi(\mathrm{i})$ parameter from the Fluorescence Regional Integration (FRI) method, as described by W. Chen et al. (2003b) and C. Jacquin et al.(2018). The volume of fluorescence and the reduction in the fluorescentorganic matter compounds are shown in table Table 6-6. 
Table 6-6 - Volume of fluorescence $\Phi(i)$ and the reduction in the concentration of fluorescent compounds after UF.

\begin{tabular}{|c|c|c|c|c|c|c|c|}
\hline \multirow[b]{3}{*}{ Region } & \multicolumn{4}{|c|}{$\begin{array}{c}\text { Volume } \\
\text { of Fluorescence (R.U.nm²) }\end{array}$} & \multirow{2}{*}{\multicolumn{3}{|c|}{$\begin{array}{l}\text { Reduction of fluorescent } \\
\text { compounds (\%) } \\
\Phi(\mathrm{i})_{\text {Feed }}-\Phi(\mathrm{i})_{\text {Permeate }}\end{array}$}} \\
\hline & \multirow{2}{*}{$\begin{array}{l}\text { Feed solution } \\
\text { (PMTE) }\end{array}$} & \multicolumn{3}{|c|}{ UF Permeate } & & & \\
\hline & & $10 \mathrm{kDa}$ & $50 \mathrm{kDa}$ & $100 \mathrm{kDa}$ & $10 \mathrm{kDa}$ & $50 \mathrm{kDa}$ & $100 \mathrm{kDa}$ \\
\hline$\overline{I I}$ & $2,950,264.07$ & $101,853,482.64$ & $\bar{~} 1,853,482.64$ & 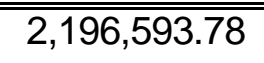 & $\bar{~} 59.17$ & 40.85 & 34.1 \\
\hline II & $10,685,689.19$ & $10,685,689.19$ & $10,685,689.19$ & $10,685,689.19$ & 51.62 & 37.48 & 27.26 \\
\hline III & $13,142,967.02$ & $13,142,967.02$ & $13,142,967.02$ & $13,142,967.02$ & 20.42 & 18.55 & 3.62 \\
\hline IV & $5,173,347.62$ & $5,173,347.62$ & $5,173,347.62$ & $5,173,347.62$ & 24.15 & 19.83 & 15.84 \\
\hline V & $4,170,485.25$ & $4,170,485.25$ & $4,170,485.25$ & $4,170,485.25$ & 6.43 & 7.57 & 3.91 \\
\hline Total & $36,122,753.15$ & $36,122,753.15$ & $36,122,753.15$ & $36,122,753.15$ & 29.47 & 24.41 & 13.04 \\
\hline
\end{tabular}


In addition to the results shown in Table 6-6, the membrane filtration process reduced the concentration of fluorescent compounds, mainly in regions I, II, and IV and it can be observed that the reduction in the concentration of fluorescent compounds increased when the MWCO decreased, which may confirm that the colloidal matter (i.e., particle size $>220 \mathrm{~nm}$ ) plays a major role in membrane fouling. Moreover, depending on their size, this suggests that the main types of fouling are pore-blocking, followed by cake formation and growth during UF. In addition, in the graph of $t / V$ versus $V_{f}$ (Figure 6-6), the linear trend confirms this assumption and makes it possible to calculate the colloid specific resistance.

Nevertheless, the quantitative volume of fluorescence in regions III and $\mathrm{V}$ (fulvic acids and humic acids) was not significantly decreased as can be seen in Table 6-6 confirming their affiliation to hydrophilic and low MW compounds. These results were confirmed by the minimal SUVA removal in the permeates shown in Table 6-5, indicating that humic concentrations remained almost the same after the UF. It can also be seen that Fulvic-like and humic-like proteins (dissolved substances) predominated in the permeate with low-MW concentration. In this study the specific UV absorbance (SUVA) and TOC were used to assess the aromatic carbon and humic substance (HS) content of the DCS in the feed solution (PMTE) and permeates.

To understand the role of organic matter (DCS) on membrane fouling, 3DEEM spectra of the foulants extracted from membranes fouled by PMTE are presented in Figure $6-11$. This analysis was carried out in accordance with the one proposed by Jacquin et al.(2017). The organic matter was thus, combined into three regions of fluorophore groups:

- Associated with colloidal proteins (regions I + II) denominated by protein -like substances I+II;

- Associated with dissolved organic matter (region III + IV) termed fluvic acidlike and humic acid-like substances (FA+HA-like); and

- Associated with macromolecular proteins present in the dissolved phase (region IV) denominated by SMP-like substances. 

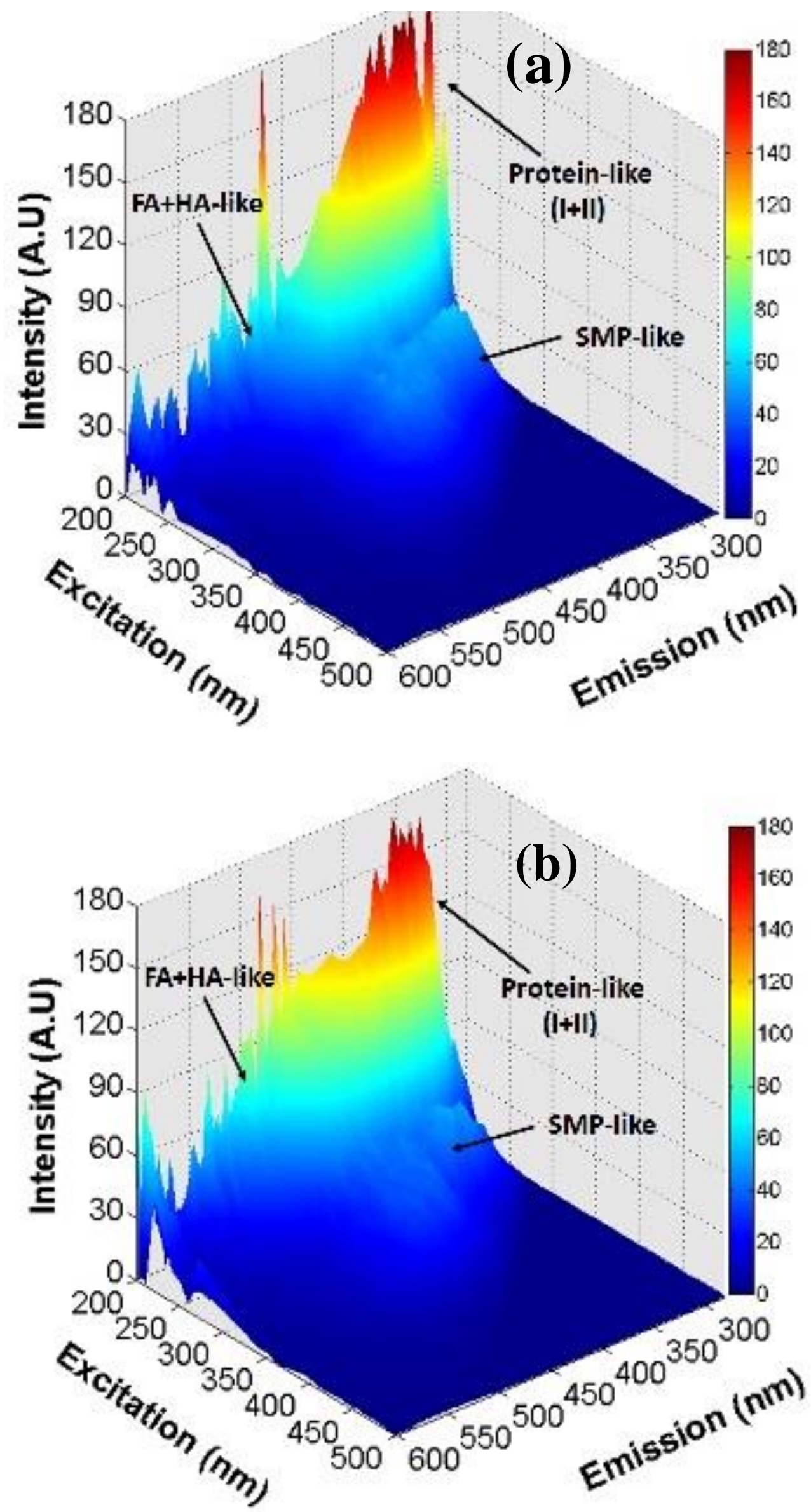


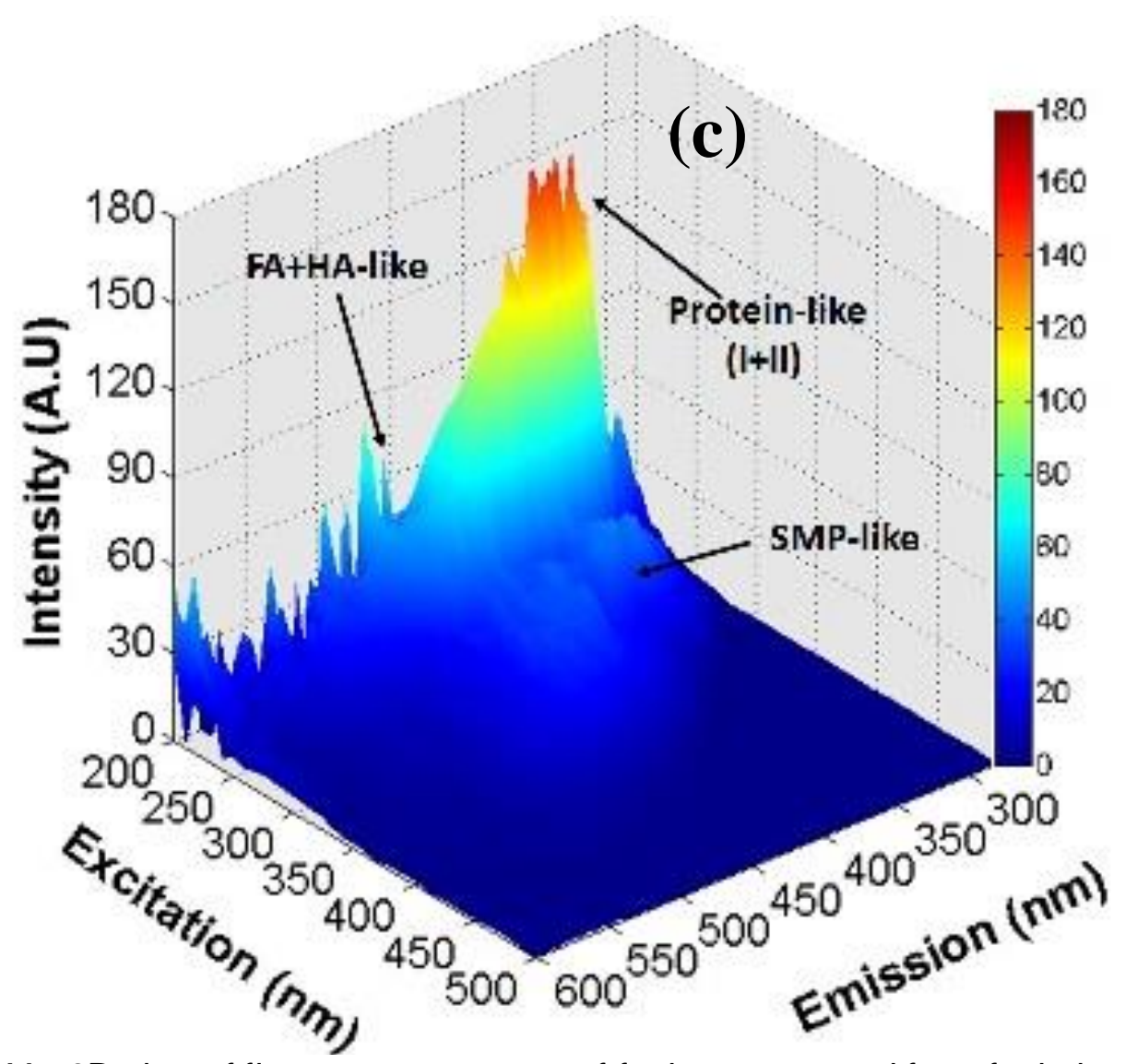

Figure 6-11 - 3D view of fluorescence spectra of foulants extracted from fouled membranes at the end of filtration (dead-end filtration protocol): (a) $10 \mathrm{kDa}$; (b) $50 \mathrm{kDa}$, and (c) $100 \mathrm{kDa}$.

It can be observed that the organic foulants with fluorescence characteristics extracted from the fouled membranes were significantly different from the PMTE and permeates (Figure 6-11). In addition, the fluorescence intensity of the 3DEEM spectra demonstrates that the colloidal proteins (protein-like substances I+II) and macromolecular proteins (SMP-like substances) were major fluorescent components on the fouled membranes, which agrees with previous studies carried out by Wang et al. (2008), Z. Wang et al.(2009) and Zhu et al.(2011), that reported one of the main compounds in membrane foulants as being proteins (tyrosine, BOD 5 and tryptophan). The quantitative comparison of the fluorescent organic foulants on the fouled membranes was carried out by using the volume of fluorescence parameter from the Fluorescence regional Integration method. The distribution of $\Phi$ for the fouled membranes is presented in Figure 6-12. 


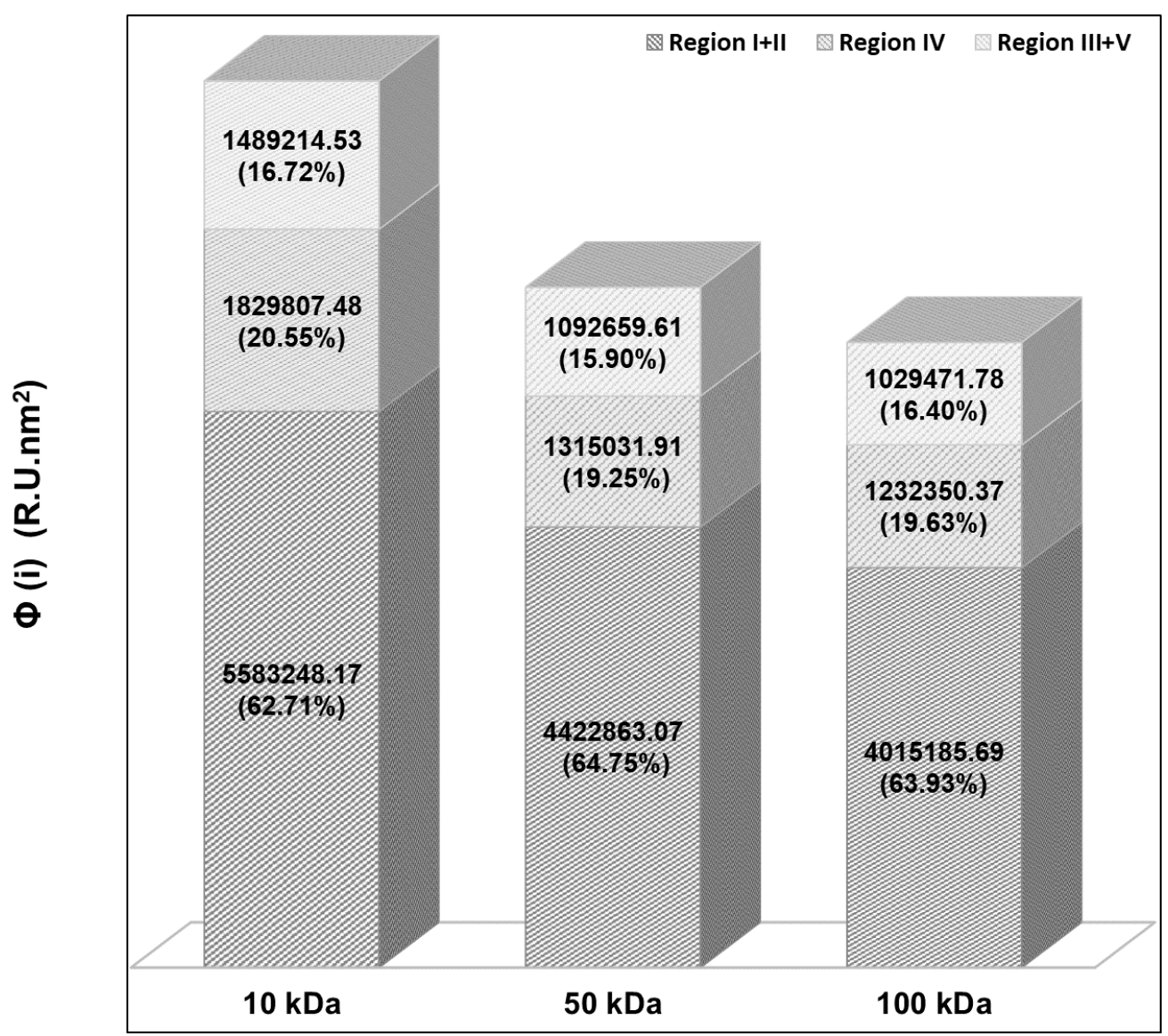

Figure 6-12 - Volumen of fluorescence distribution for the foulants extracted of three different PES membranes.

In Figure 6-12, it can be observed that the $\Phi$ (i) distribution of the three different PES membrane was clearly different, which might be due to the differentcomposition and retention in terms of fluorophore compounds on the fouled membranes. Hence, protein-like substances I+II comprised the fraction most retained by the membranes with approximately $62.71 \%$ retained by the $10 \mathrm{kDa}$ membrane, around $64.75 \%$ for the $50 \mathrm{kDa}$ membrane, and $63.93 \%$ for the $10 \mathrm{kDa}$ membrane, followed by SMP-like molecules with around $20.55 \%$ retained by the $10 \mathrm{kDa}$ membrane, $19.25 \%$ by the 50 $\mathrm{kDa}$ membrane, and $19.63 \%$ by the $100 \mathrm{kDa}$ membrane. Moreover, it can be noted that the total $\Phi(\mathrm{i})$ increased as the MWCO decreased, $100 \mathrm{kDa}$ to $50 \mathrm{kDa}$ followed by 10 $\mathrm{kDa}$. This foulant behavior can be explained by the hydrophobic characteristic and relatively higher MW or molecular mass in comparison with the membrane cut-off. However, FA+HA-like substances (strong hydrophobicity) were also found as a component of the membrane foulants, even though the dissolved organic matter was found in a lesser amount than colloidal proteins. In addition, they might be associated 
with irreversible fouling, due to their hydrophobic adhesion effect over and inside the membranes and as they affect both the hydraulic permeability and the rejection membrane properties (C. Jacquin et al., 2018; Crozes et al., 1993; Liu et al., 2014).

\subsubsection{ATR-FTIR analysis}

Fourier transform infrared spectroscopy was used to characterize and identify the major foulant groups, including the DCS, retained on the fouled membranes. ATRFTIR is a rapid and reliable method used to detect the presence of differentbands in the fouling layer (chemical functional groups), such as proteins, fatty and resin acids, colloids, and polysaccharides (Belfer et al., 2000). However, the chemical complexity of paper mill effluents makes it difficult to be precise in characterizing membrane fouling using the FTIR test. Notwithstanding this, an importantcharacteristic of all these foulant compounds is that they contain a $\mathrm{C}=\mathrm{O}$ group in their structures, such as in the carboxylic acids $[-\mathrm{C}(=\mathrm{O})-\mathrm{OH}]$ or carboxylate $\left[-\mathrm{C}(=\mathrm{O})-\mathrm{O}^{-}\right]$, and this bond absorbs in a strong band in the range around $1690-1750 \mathrm{~cm}^{-1}$ and $1550 \mathrm{~cm}^{-1}$, respectively, in addition all the carbohydrates absorb at about $3400 \mathrm{~cm}^{-1}(-\mathrm{C}-\mathrm{OH})$ and at about 1060 $\mathrm{cm}^{-1}$ (-C-OH or C-O-C) (Carlsson et al., 1998). Thus, this band is significant in IR (Infrared) fouling analysis of fouled membranes.

Several FTIR spectra from UF membranes (10 kDa, $50 \mathrm{kDa}$ and $100 \mathrm{kDa})$ were obtained in this study, the infrared spectra of the fresh PES UF membrane and fouled membranes by filtration of PMTE (dead-end filtration protocol section 6.3.1) with $\mathrm{NaHCO}_{3}(1 \mathrm{mmol} / \mathrm{L})$ are provided in Figure 6-13. 

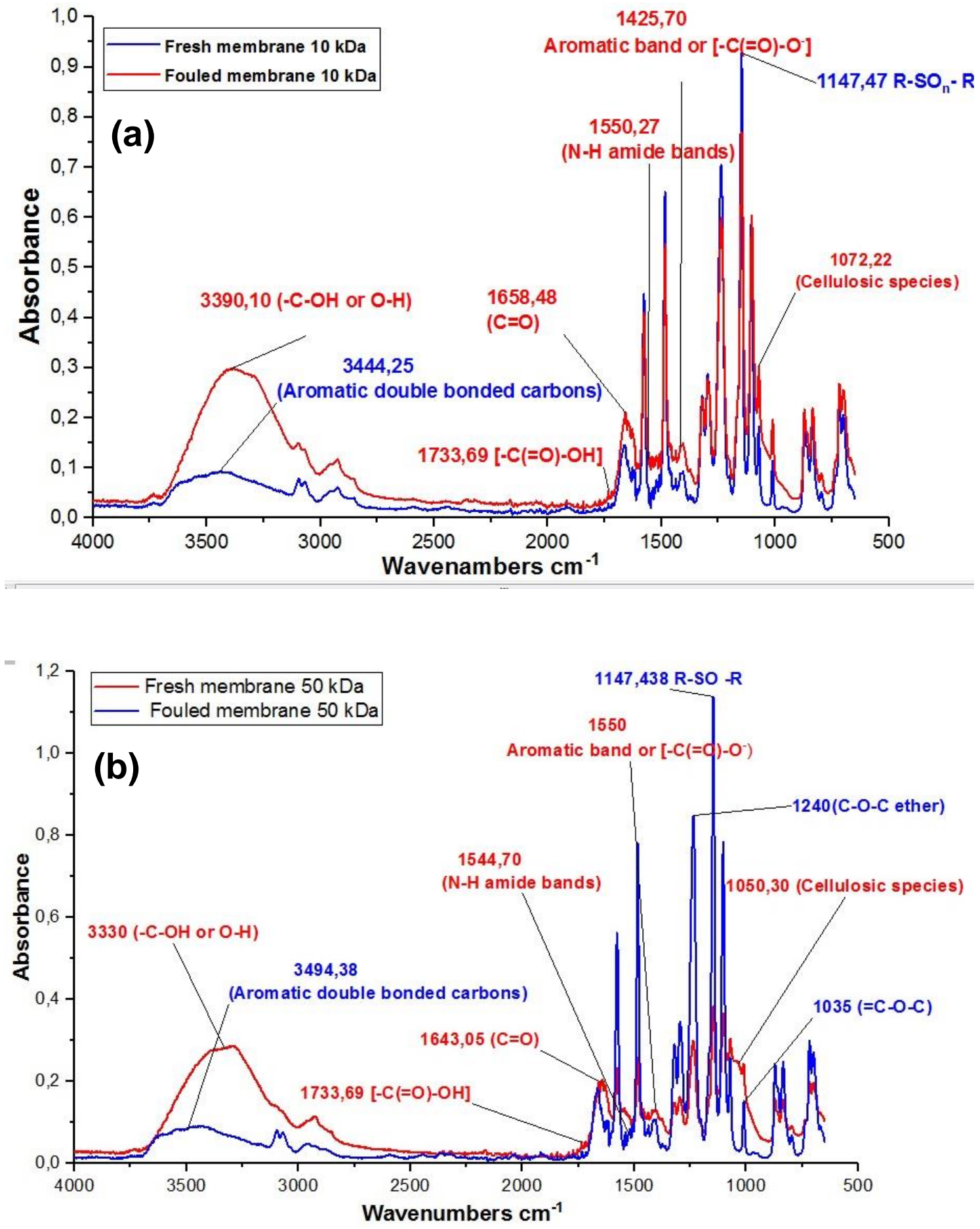

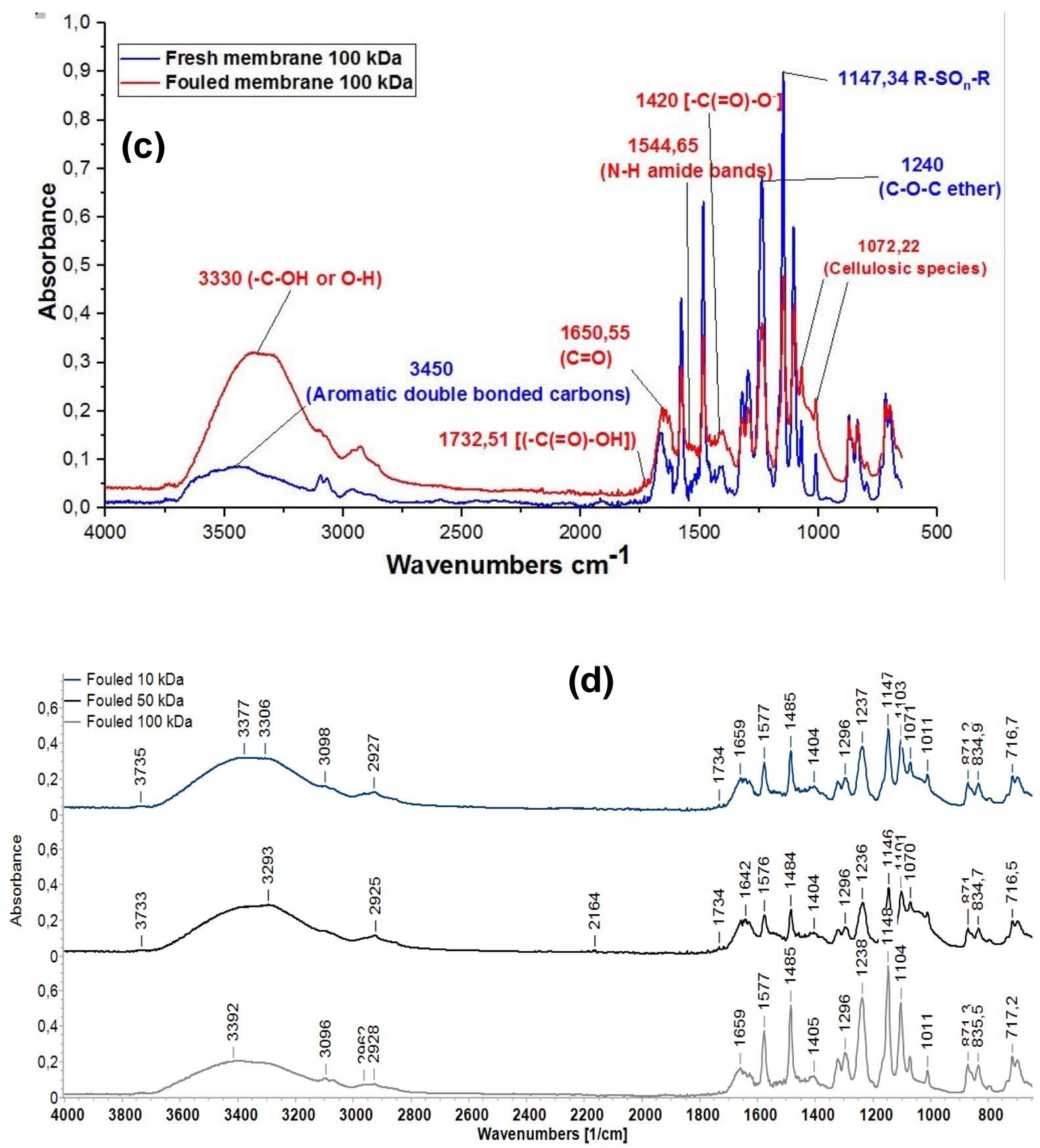

Figure 6-13 - ATR-FTIR spectra comparison of fresh PES membrane and fouled membrane:

(a) $10 \mathrm{kDa}$; (b) $50 \mathrm{kDa}$, and (c) $100 \mathrm{kDa}$ (the IR spectrum comparison between MWCO membranes were almost the same) and DCS- fouled PES membranes (10 kDa, 50kDa and $100 \mathrm{kDa}$ ) by PMTE filtration (d).

The broad bands between 3250 and $3400 \mathrm{~cm}^{-1}$, were attributed to the overlapping of bands from the stretching vibrations of the $\mathrm{N}-\mathrm{H}$ stretching in amides and the $\mathrm{O}-\mathrm{H}$ stretching in the hydroxyl groups in the polysaccharides (DCS) with in the membrane (Howe et al., 2002; Jarusutthirak et al., 2002). 
The bands between $2900 \mathrm{~cm}^{-1}$ and $2850 \mathrm{~cm}^{-1}$, which correspond to aliphatic- $\mathrm{CH}_{2}$ asymmetrical stretching and symmetrical groups (Goh et al., 2011), and the bands near $1080 \mathrm{~cm}^{-1}$ and $1070 \mathrm{~cm}^{-1}$, which correspond to $\mathrm{CH}$ aromatics (Dhakal, 2017), can both relate to the presence of humic substances.

The peaks absorbed at wavelengths around $1730 \mathrm{~cm}^{-1}$ were indications of carboxylic groups attributed to fatty acids (carboxylic acid) and resin acids (carboxylate ion), both recognized contaminants in recycled paper mill effluent treated by aerobic and anaerobic reactor, and they suggest a strong source of the membrane fouling (Ramamurthy et al., 1995).

The peaks located at $1650.55 \mathrm{~cm}^{-1}$ and $1544.65 \mathrm{~cm}^{-1}$ are due to $\mathrm{C}=\mathrm{O}$ stretching in amide I and amide II attributed to the presence of proteins (Maruyama, 2001; Zhu et al., 2011), suggesting they are a component of the EPS attached to the membrane surface.

The peaks around $1072 \mathrm{~cm}^{-1}$ might suggest that polysaccharide-like substances (cellulosic species) are significant foulants on the membrane (Her et al., 2004; Kallioinen et al., 2003; Kimura et al., 2005).

The identified functional groups and the typical organic compounds based on the IR spectra associated with the foulants in the membranes fouled by DCS coming from the paper mill treated effluent are shown in Table 6-7.

Table 6-7- Peaks and assignments of infrared spectra for clean and fouled membranes.

\begin{tabular}{ccc}
\hline $\begin{array}{c}\text { Absorption Peak } \\
\left(\mathrm{cm}^{-1}\right)\end{array}$ & Associated Group & Compound \\
\hline \hline 1050 & $\mathrm{C}-\mathrm{O}$ stretching and/or & Polysaccharide-like or Sugar ester \\
& Stretching $-\mathrm{S}=\mathrm{O}$ & sulphates \\
$1100-1080$ & $\mathrm{CH}$ aromatic & Humic substances \\
$1570-1545$ & Amide II $(\mathrm{C}-\mathrm{N}$ and $\mathrm{N}-\mathrm{H}$ bonds $)$ & Proteins \\
$1670-1630$ & Amide I $(\mathrm{C}=\mathrm{O})$ & Proteins \\
1730 & {$[-\mathrm{C}(=\mathrm{O})-\mathrm{OH}]$} & Fatty acids \\
$2900-2850$ & Aliphatic- $\mathrm{CH}$ stretching & Humic substances \\
& Bonded $\mathrm{N}-\mathrm{H} / \mathrm{C}-\mathrm{H} / \mathrm{O}-\mathrm{H}$ stretching & Proteins, Polysaccharides and \\
$3400-3330$ & vibration mode & Humic substances \\
\hline \hline
\end{tabular}

Interpretation of IR spectra was based on Carlsson et al.(1998), Ramamurthy et al.(1995) and Puro et al. (2011). 
Therefore, according to the results, it can be suggested that the membrane foulants mainly consisted of fatty and resin acids, proteins, humic substances, and polysaccharides (cellulosic species), which is also consistent with the findings of the 3DEEM analysis.

Then, the comparison of the signals between fouled and cleaned membrane shows that the irreversible foulant was aliphatic- $\mathrm{CH}_{2}$ and bonded $\mathrm{N}-\mathrm{H} / \mathrm{C}-\mathrm{H} / \mathrm{O}-\mathrm{H}$ stretching (Figure 6-13 a-c).

\subsubsection{SEM and EDS analysis}

Images of the fresh and fouled membrane structures were taken using field emission scanning electron microscopy (FESEM). Furthermore, energy dispersive spectroscopy (EDS) analyses were carried out in order to investigate the inorganic composition of the foulants deposited on the membranes.

Figure 6-14 shows the surface of the fresh, fouled and cleaned PES membranes (10 kDa MWCO, $50 \mathrm{kDa}$ MWCO and $100 \mathrm{kDa}$ MWCO). The pore can be easily identified before the UF. However, as expected, in the FESEM-images of the fouled membranes, a strong fouling layer can be seen on the membrane, due to the deposit of DCS, causing adsorption and pore blockage by low-molecular weight contaminants and the formation of a cake layer by macromolecular contaminants accumulated on the membrane surface.

EDS analysis was, therefore, performed to investigate the inorganic foulants composition and to study the influence of metal ions on membrane fouling. The elemental composition (EDS results) of both membranes (fresh and fouled) is shown in Figure 6-15 and Table 6-8. 


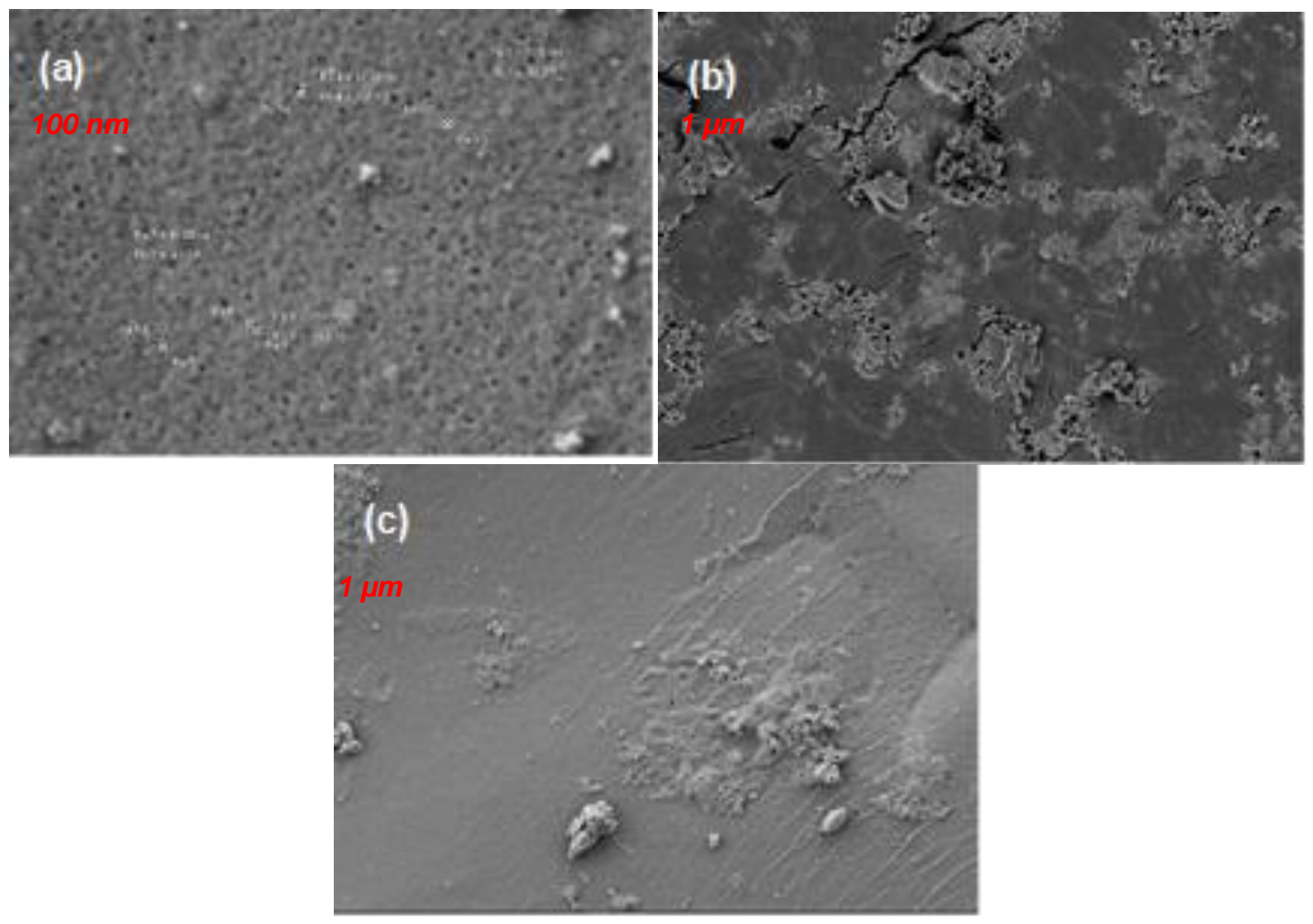




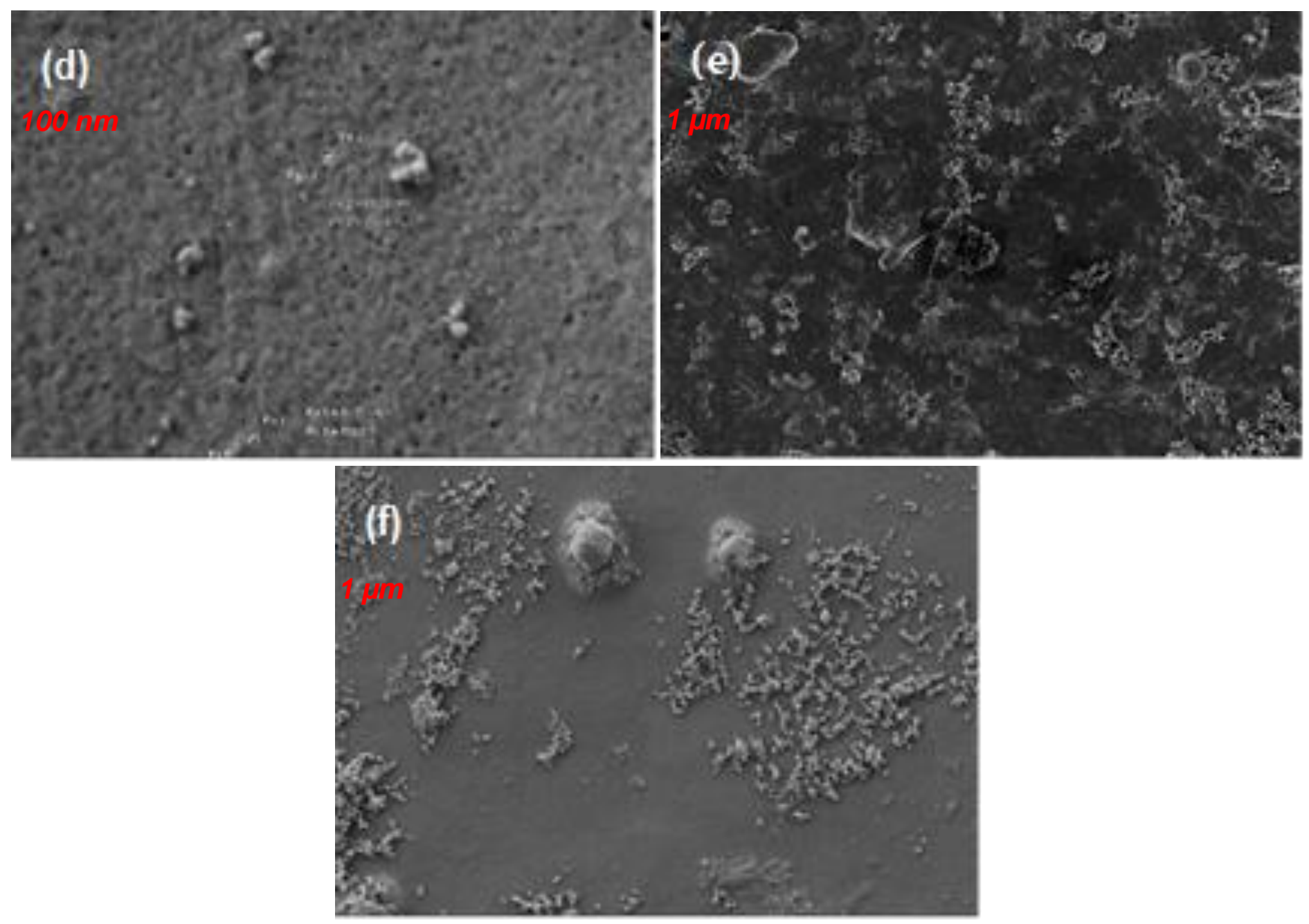



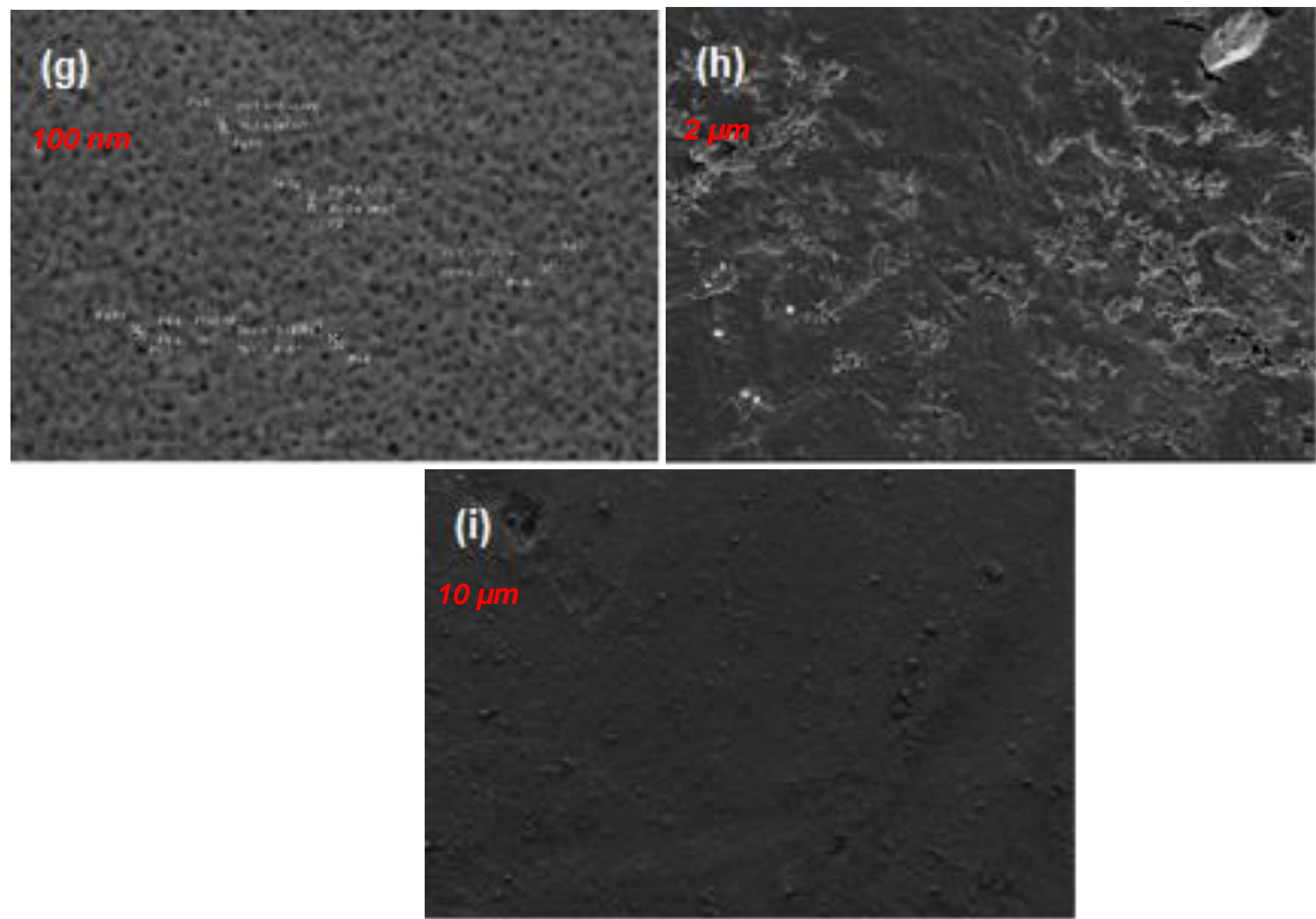

Figure 6-14 - FESEM images of the membrane surfaces (a) fresh $10 \mathrm{kDa}$ MWCO; (b) fouled $10 \mathrm{kDa}$ MWCO; (c) cleaned $10 \mathrm{kDa}$ MWCO, (d) fresh 50 kDa MWCO; (e) fouled 50 kDa MWCO; (f) cleaned 50 kDa MWCO, (g) fresh 100 kDa MWCO; (h) fouled 100 kDa MWCO; (i) cleaned 100 kDaMWCO. 

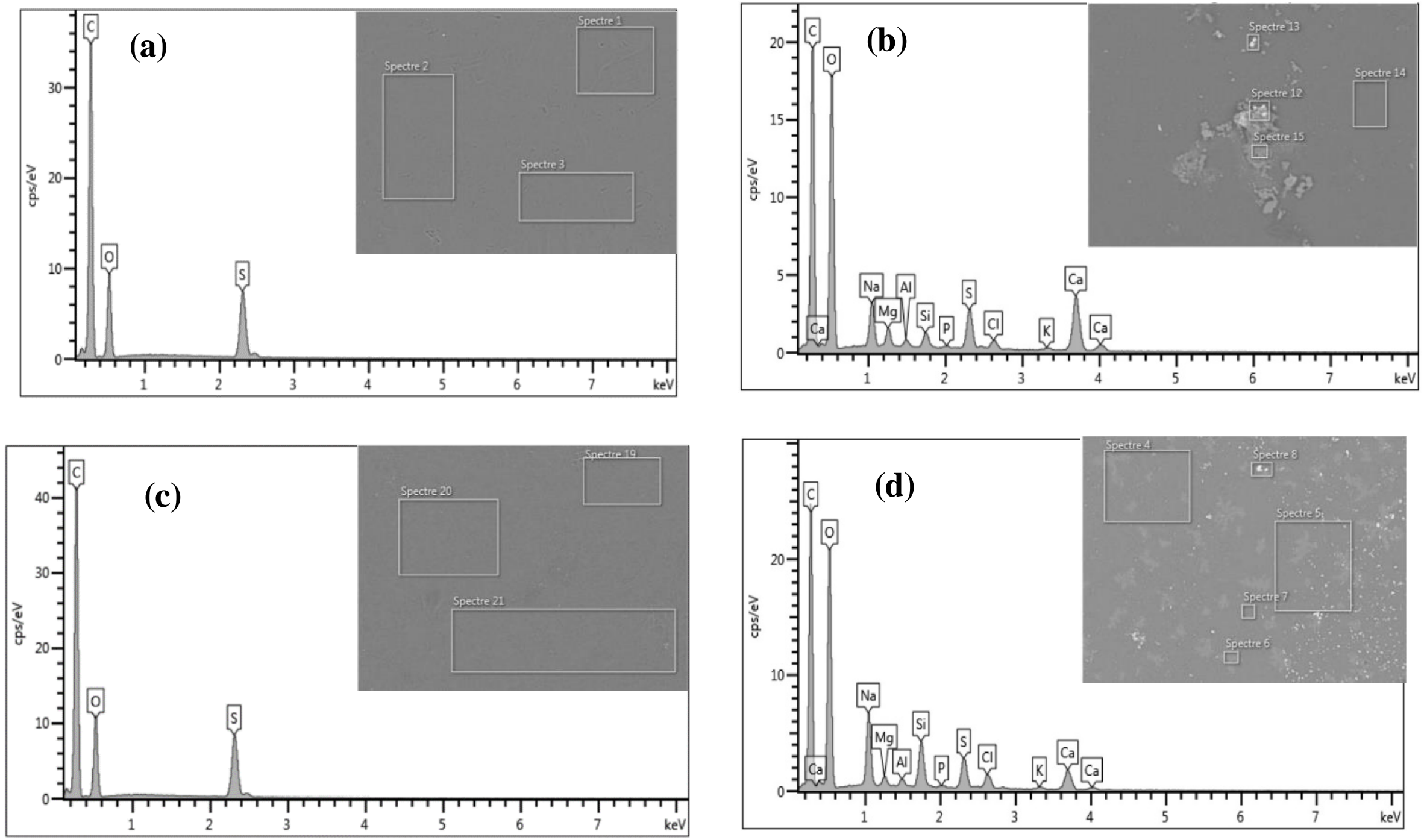

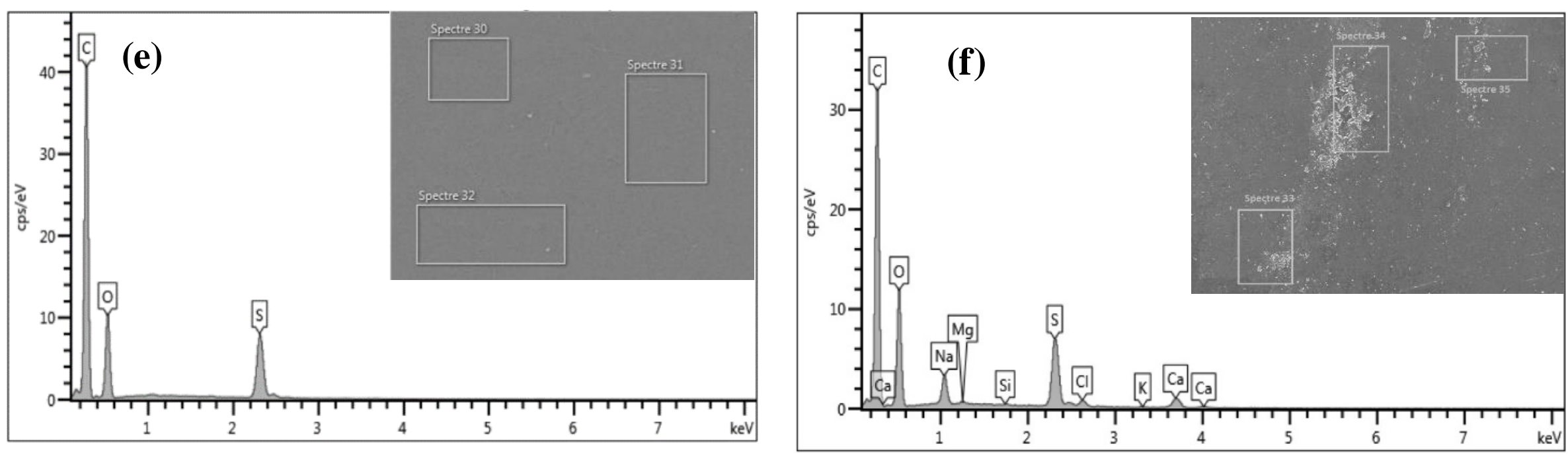

Figure 6-15 - EDS spectrum of the membrane surfaces (a) fresh 10 kDa MWCO; (b) fouled 10 kDa MWCO; (c) fresh 50 kDa MWCO; (d) fouled 50 kDa MWCO; (e) fresh 100 kDa MWCO; (f) fouled 100 kDa MWCO. 
Table 6-8 - Inorganic composition of fresh and fouled membranes.

\begin{tabular}{|c|c|c|c|c|c|c|c|c|c|}
\hline \multirow[b]{3}{*}{ Element } & \multicolumn{3}{|c|}{ 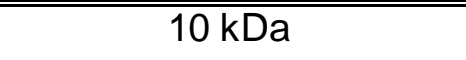 } & \multicolumn{3}{|c|}{ 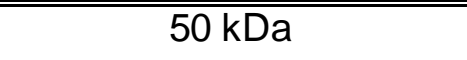 } & \multicolumn{3}{|c|}{$10100 \mathrm{kDa}$} \\
\hline & Fresh & "Fouled & Cleaned & Fresh & Fouled & Cleaned & Fresh & Fouled & Cleaned \\
\hline & $\begin{array}{c}\text { Weight } \\
(\%)\end{array}$ & $\begin{array}{c}\text { Weight } \\
(\%)\end{array}$ & $\begin{array}{c}\text { Weight } \\
(\%)\end{array}$ & $\begin{array}{c}\text { Weight } \\
(\%)\end{array}$ & $\begin{array}{c}\text { Weight } \\
(\%)\end{array}$ & $\begin{array}{c}\text { Weight } \\
(\%)\end{array}$ & $\begin{array}{c}\text { Weight } \\
(\%)\end{array}$ & $\begin{array}{c}\text { Weight } \\
(\%)\end{array}$ & $\begin{array}{c}\text { Weight } \\
(\%)\end{array}$ \\
\hline $\bar{C}$ & "68.89 & "69.62 & 699.09 & $4 \quad 41.10$ & 49.13 & "63.88 & 71.67 & 699.60 & "67.76 \\
\hline 0 & 18.60 & 18.53 & 18.72 & 33.14 & 29.36 & 19.47 & 16.39 & 18.33 & 18.47 \\
\hline$S$ & 12.50 & 11.84 & 12.18 & 4.28 & 3.70 & 9.70 & 10.53 & 9.75 & 3.70 \\
\hline $\mathrm{Na}$ & - & - & - & 2.77 & 4.87 & 2.15 & 0.34 & 0.77 & 1.92 \\
\hline $\mathrm{Mg}$ & - & - & - & 1.08 & 0.63 & 0.16 & - & - & - \\
\hline $\mathrm{Si}$ & - & - & - & 1.03 & 3.63 & 0.08 & - & - & - \\
\hline $\mathrm{Cl}$ & - & - & - & 1.22 & 2.17 & 1.09 & 0.58 & 0.70 & 1.99 \\
\hline $\mathrm{K}$ & - & - & - & 0.43 & 0.56 & 0.17 & 0.37 & 0.28 & 0.75 \\
\hline $\mathrm{Ca}$ & - & - & - & 14.50 & 5.95 & 3.30 & 0.13 & 0.52 & 0.55 \\
\hline $\mathrm{Al}$ & - & - & - & 0.44 & 0.41 & - & - & 0.04 & - \\
\hline Total: & 100 & 100 & 100 & 100 & 100 & 100 & 100 & 100 & 100 \\
\hline
\end{tabular}

EDS analyses confirm that carbon, oxygen and sulfurwere the main elements detected in the fresh PES membranes, which agrees with the elemental chemical composition of polyethersulfone. In addition, it is easy to see the presence of most metal elements (sodium, calcium, magnesium and silicate) on the fouled membranes, especially calcium, due to inorganic foulants (Erkan and Engin, 2017).

In addition, the $\mathrm{C}, \mathrm{O}$ and $\mathrm{S}$ concentrations (weight \%) were found to be different between the fresh and fouled membranes. The ratios of the different metal ions $\left(\mathrm{Na}^{+}\right.$, $\left.\mathrm{Mg}^{2+}, \mathrm{SiO}_{4}^{4-}, \mathrm{Cl}^{-}, \mathrm{Ca}^{2+}, \mathrm{K}^{+}, \mathrm{Al}^{3+}\right)$ on the fouled membrane surfaces were found to be different for the different MWCOs (10 kDa, $50 \mathrm{kDa}$ and $100 \mathrm{kDa}$ ).

It is worth mentioning that, as described by Chen et al.(2015), the interaction between the multivalent metal ions (electrolytes), such as $\mathrm{Ca}^{2+}$ and $\mathrm{Mg}^{2+}$, can alter the thermodynamic and the kinetic stability of DCS via a Ca-and Mg-DCS complex and aggregate formation (Bobacka et al., 1998). This consequently contributes to pore blocking and cake formation on the membrane surface during UF caused by the complexing of rejected colloids and metal ions in the PMTE which is confirmed through 
EDS analysis of $\mathrm{Cl}^{-}, \mathrm{K}^{+}$and $\mathrm{Ca}^{2+}$ on washed membrane while $\mathrm{Mg}$ and $\mathrm{Si}$ were not detected.

Moreover, Dorica et al. (1986) described that, under alkaline conditions, fatty and resin acids (foulant compounds identified by ART-FTIR) are probably present in the form of calcium salts and a small fraction of them could coagulate and deposit on the membranes and consequently increase pore blocking.

\section{5 conclusions}

Three different MWCO (PES) membranes were studied to estimate the degree of fouling caused by dissolved and colloidal matter (DCS), which come from paper mill treated effluent.

Thus, it can clearly be seen that for the same specific filtration volume $6.0 \mathrm{ml} . \mathrm{m}^{-2}$ (i.e $250 \pm 0.5 \mathrm{ml}$ of PMTE) for the lowest MWCO $(10 \mathrm{kDa})$, the flux decline was smaller and slower compared to the larger MWCO (100 kDa presented the greatest initial flux and very quickly flux declined, mainly during the first few minutes of the filtration, which can be attributed to the deposition of the DCS and adsorption into the membrane pores). In addtion, the fouling resistance during the filtration of PMTE increased when the MWCO increased from $10 \mathrm{kDa}$ to $50 \mathrm{kDa}$ and $100 \mathrm{kDa}$. This suggests that larger pore size induces higher flow resistance probably due to higher cake formation and intermediate pore blocking, which was confirmed by the trend of fouling constant $K_{c f}$ and $K_{c b}$, resulting in a greater degree of fouling. For all membranes, cake formation became the most dominant mechanism for permeate flux decline during UF of the PMTE. It indicates that majority of foulants (macromolecules and colloids such as proteins and polysaccharides) in feed solution (Miao et al., 2012) have bigger size than membrane pores.

The 3DEEM analysis found that the dominant fluorescent substances on the fouled membranes were mainly associated with colloidal proteins and macromolecular proteins present in the dissolved phase as soluble microbial by-product-like materials, which might be explained by the protein-like substances I+ll and the SMP-like substances in the DCS having a higher molecular weight than the MWCO and strong hydrophobic adhesion over the membrane pores, meaning they were consequently retained by the fine membrane pores and played a major role in the fouling on 
polyethersulfone UF membranes, whereas fluvic acid-like and humic acid-like substances were of lesser relevance..

The ATR-FTIR and 3DEEM results agree with previous studies carried out by $\mathrm{C}$. Jacquin et al.( 2018), Puro et al.(2011) and Ramamurthy et al.(1995). So, it can be concluded that hydrophobic substances with large molecular weight, such as protein like substances and polysaccharides, are mostly responsible for UF membrane fouling, whereas humic substances, which account for the majority of the dissolved organic matter in DCS, played a minor role. Therefore, the deposition and adsorption of proteins and polysaccharides during UF should be controlled by optimizing operational conditions, such as transmembrane pressure (TMP), cross-flow velocity (CFV), temperature and molecular weight cut-off (MWCO).

FESEM and EDS analyses indicated that the foulants accumulated and adsorbed on to the membrane surfaces comprised not only organic matter but also inorganic elements including $\mathrm{Na}, \mathrm{Mg}, \mathrm{Si}, \mathrm{Cl}, \mathrm{Ca}, \mathrm{K}$, and $\mathrm{Al}$. These results showed that the presence of multivalent metal ions, especially $\mathrm{Ca}^{2+}$, on the fouled membrane can accelerate membrane fouling and can also contribute to irreversible fouling, whereas $\mathrm{Mg}$ and $\mathrm{Si}$ induce reversible fouling 


\subsection{References}

Bayr, S., Rintala, J., 2012. Thermophilic anaerobic digestion of pulp and paper mill primary sludge and co-digestion of primary and secondary sludge. Water Research 46, 4713-4720. https://doi.org/10.1016/j.watres.2012.06.033

Belfer, S., Fainchtain, R., Purinson, Y., Kedem, O., 2000. Surface characterization by FTIR-ATR spectroscopy of polyethersulfone membranes-unmodified, modified and protein fouled. Journal of Membrane Science 172, 113-124. https://doi.org/10.1016/S0376-7388(00)00316-1

Bobacka, V., Näsman, J., Eklund, D., 1998. Interactions between cationic starch and anionic trash of a peroxide-bleached TMP at different salt concentrations. Journal of Pulp and Paper Science 24, 78-81.

Bowen, W.R., Calvo, J.I., Hernández, A., 1995. Steps of membrane blocking in flux decline during protein microfiltration. Journal of Membrane Science 101, 153165. https://doi.org/10.1016/0376-7388(94)00295-A

C. Jacquin, C., Teychene, B., Lemee, L., Lesage, G., Heran, M., 2018. Characteristics and fouling behaviors of Dissolved Organic Matter fractions in a full-scale submerged membrane bioreactor for municipal wastewater treatment. Biochemical Engineering Journal 132, 169-181. https://doi.org/10.1016/j.bej.2017.12.016

Carlsson, D.J., Dal-Cin, M.M., Black, P., Lick, C.N., 1998. A surface spectroscopic study of membranes fouled by pulp mill ef ${ }^{-}$uent. Journal of Membrane Science 11.

Carstea, E.M., Bridgeman, J., Baker, A., Reynolds, D.M., 2016. Fluorescence spectroscopy for wastewater monitoring: A review. Water Research 95, 205219. https://doi.org/10.1016/j.watres.2016.03.021

Chang, I.-S., Kim, S.-N., 2005. Wastewater treatment using membrane filtrationeffect of biosolids concentration on cake resistance. Process Biochemistry 40, 1307-1314. https://doi.org/10.1016/j.procbio.2004.06.019

Chen, C., Mao, S., Wang, J., Bao, J., Xu, H., Su, W., Dai, H., 2015. Application of Ultrafiltration in a Paper Mill: Process Water Reuse and Membrane Fouling 
Analysis. $\quad$ BioResources $\quad 10, \quad 2376-2391$. https://doi.org/10.15376/biores.10.2.2376-2391

Chen, W., Westerhoff, P., Leenheer, J.A., Booksh, K., 2003b. Fluorescence Excitation-Emission Matrix Regional Integration to Quantify Spectra for Dissolved Organic Matter. Environmental Science \& Technology 37, 57015710. https://doi.org/10.1021/es034354c

Crozes, G., Anselme,C., Mallevialle,J., 1993. Effect of adsorption of organic matter on fouling of ultrafiltration membranes. Journal of Membrane Science 84, 6177. https://doi.org/10.1016/0376-7388(93)85051-W

Dhakal, N., 2017. Controlling Biofouling in Seawater Reverse Osmosis Membrane Systems, 1st ed. CRC Press. https://doi.org/10.1201/9781351056106

Dorica, J., Wong, A., Garner, B.C., 1986. Complete effluent recycling in the bleach plant with ultrafiltration and reverse osmosis. Tappi journal 69, 122-125.

Erkan, H.S., Engin, G.O., 2017. The investigation of paper mill industry wastewater treatment and activated sludge properties in a submerged membrane bioreactor. Water Sci. Technol. 76, 1715-1725. https://doi.org/10.2166/wst.2017.351

Goh, Y.T., Harris, J.L., Roddick, F.A., 2011. Impact of Microcystis aeruginosa on membrane fouling in a biologically treated effluent. Water Sci. Technol. 63, 2853-2859.

Goletz, C., Wagner, M., Grübel, A., Schmidt, W., Korf, N., Werner, P., 2011. Standardization of fluorescence excitation-emission-matrices in aquatic milieu. Talanta 85, 650-656. https://doi.org/10.1016/j.talanta.2011.04.045

Her, N., Amy, G., Park, H.-R., Song, M., 2004. Characterizing algogenic organic matter (AOM) and evaluating associated NF membrane fouling. Water Research 38, 1427-1438. https://doi.org/10.1016/j.watres.2003.12.008

Hermia, J., 1982. Constant Pressure Blocking Filtration Laws - Application To Power-law Non-newtonian Fluids. Institution of Chemical Engineers. Transactions 60, 183. 
Howe, K.J., Ishida, K.P., Clark, M.M., 2002. Use of ATR/FTIR spectrometry to study fouling of microfiltration membranes by natural waters. Desalination $147,251-$ 255. https://doi.org/10.1016/S0011-9164(02)00545-3

Hubbe, M.A., Sundberg, A., Mocchiutti, P., Ni, Y., Pelton, R., 2012. DISSOLVED AND COLLOIDAL SUBSTANCES (DCS) AND THE CHARGE DEMAND OF PAPERMAKING PROCESS WATERS AND SUSPENSIONS: A REVIEW. BioResources 7, 6109-6193. https://doi.org/10.15376/biores.7.4.6109-6193

Jacquin, C., Lesage, G., Traber, J., Pronk, W., Heran, M., 2017. Three-dimensional excitation and emission matrix fluorescence (3DEEM) for quick and pseudoquantitative determination of protein- and humic-like substances in full-scale membrane bioreactor (MBR). Water Research 118, 82-92. https://doi.org/10.1016/j.watres.2017.04.009

Jarusutthirak, C., Amy, G., Croué, J.-P., 2002. Fouling characteristics of wastewater effluentorganic matter (EfOM) isolates on NF and UF membranes. Desalination 145, 247-255. https://doi.org/10.1016/S0011-9164(02)00419-8

Kallioinen, M., Reinikainen, S.-P., Nuortila-Jokinen, J., 2003. Membrane foulant characterization in pulp and paper applications. Presented at the 5th International Membrane Science and Technology Conference (IMSTEC'03), Sydney, Australia, 2003.

Kimura, K., Yamato, N., Yamamura, H., Watanabe, Y., 2005. Membrane Fouling in Pilot-Scale Membrane Bioreactors (MBRs) Treating Municipal Wastewater. Environ. Sci. Technol. 39, 6293-6299. https://doi.org/10.1021/es0502425

Kossar, M.J., Amaral, K.J., Martinelli, S.S., Erbe, M.C.L., 2013. Proposal for water reuse in the Kraft pulp and paper industry. Water Practice and Technology 8 , 359-374. https://doi.org/10.2166/wpt.2013.036

Lee, S., 2013. Fouling characteristics of ceramic microfiltration and ultrafiltration membranes during surface water treatment.

Liu, H., Li, M., Zhu, K., Ma, H., Wu, Y., Wang, Z., Wang, S., 2020. Analysis of Dissolved and Colloidal Substances in Old Corrugated Containers' Whitewater and Dissolved Substances' Impact on Colloidal Substances' Stability. BioResources 15, 6668-6679. 
Liu, Y., Bo, S., Zhu, Y., Zhang, W., 2003. Determination of molecular weight and molecular sizes of polymers by high temperature gel permeation chromatography with a static and dynamic laser light scattering detector. Polymer 44, 7209-7220. https://doi.org/10.1016/j.polymer.2003.08.037

Liu, Y., Li, X., Yang, Y., Ye, W., Ji, S., Ren, J., Zhou, Z., 2014. Analysis of the major particle-size based foulants responsible for ultrafiltration membrane fouling in polluted raw water. Desalination 347, 191-198. https://doi.org/10.1016/j.desal.2014.05.039

Martínez de Peón, C., Gomez, V., Pocurull, E., Borrull, F., 2015. Characterization of organic fouling in reverse osmosis membranes by headspace solid phase microextraction and gas chromatography-mass spectrometry. Water science and technology : a journal of the International Association on Water Pollution Research 71, 117-25. https://doi.org/10.2166/wst.2014.475

Maruyama, T., 2001. FT-IR analysis of BSA fouled on ultrafiltration and microfiltration membranes. Journal of Membrane Science 192, 201-207. https://doi.org/10.1016/S0376-7388(01)00502-6

Miao, Q., Huang, L., Chen, L., 2012. Advances in the Control of Dissolved and Colloidal Substances Present in Papermaking Processes: A Brief Review. BioResources 8. https://doi.org/10.15376/biores.8.1.1431-1455

Ordóñez, R., Hermosilla, D., San Pío, I., Blanco, A., 2010. Replacement of fresh water use by final effluent recovery in a highly optimized $100 \%$ recovered paper mill. Water Sci. Technol. 62, 1694-1703. https://doi.org/10.2166/wst.2010.933

Park, M., Snyder, S.A., 2018. Sample handling and data processing for fluorescent excitation-emission matrix (EEM) of dissolved organic matter (DOM). Chemosphere 193, 530-537. https://doi.org/10.1016/j.chemosphere.2017.11.069

Peiris, R.H., Hallé, C., Budman, H., Moresoli, C., Peldszus, S., Huck, P.M., Legge, R.L., 2010. Identifying fouling events in a membrane-based drinking water treatment process using principal component analysis of fluorescence excitation-emission matrices. Water Research 44, 185-194. https://doi.org/10.1016/j.watres.2009.09.036 
Peldszus, S., Hallé, C., Peiris, R.H., Hamouda, M., Jin, X., Legge, R.L., Budman, H., Moresoli, C., Huck, P.M., 2011. Reversible and irreversible low-pressure membrane foulants in drinking water treatment: Identification by principal component analysis of fluorescence EEM and mitigation by biofiltration pretreatment. Water Research 45, 5161-5170. https://doi.org/10.1016/j.watres.2011.07.022

Poojamnong, K., Tungsudjawong, K., Khongnakorn, W., Jutaporn, P., 2020. Characterization of reversible and irreversible foulants in membrane bioreactor (MBR) for eucalyptus pulp and paper mill wastewater treatment using fluorescence regional integration. Journal of Environmental Chemical Engineering 8, 104231. https://doi.org/10.1016/j.jece.2020.104231

Puro, L., Kallioinen, M., Mänttäri, M., Natarajan, G., C. Cameron, D., Nyström, M., 2010. Performance of RC and PES ultrafiltration membranes in filtration of pulp mill process waters. Desalination 264, 249-255. https://doi.org/10.1016/j.desal.2010.06.034

Puro, L., Kallioinen, M., Mänttäri, M., Nyström, M., 2011. Evaluation of behavior and fouling potential of wood extractives in ultrafiltration of pulp and paper mill process water. Journal of Membrane Science 368, 150-158. https://doi.org/10.1016/j.memsci.2010.11.032

Puro, L., Tanninen, J., Nyström, M., 2002. Analyses of organic foulants in membranes fouled by pulp and paper mill effluent using solid-liquid extraction. Desalination 143, 1-9. https://doi.org/10.1016/S0011-9164(02)00215-1

Ramamurthy, P., Poole, R., Dorica, J.G., 1995. Fouling of ultrafiltration membranes during treatment of CTMP screw press filtrates. Journal of Pulp and Paper Science 21, J50-54.

Rudolph, G., Schagerlöf, H., Morkeberg Krogh, K.B., Jönsson, A.-S., Lipnizki, F., 2018. Investigations of Alkaline and Enzymatic Membrane Cleaning of Ultrafiltration Membranes Fouled by Thermomechanical Pulping Process Water. Membranes (Basel) 8. https://doi.org/10.3390/membranes8040091

Rushton, A., Ward, A.S., Holdich, R.G., 1995. Introduction to Solid-liquid Filtration and Separation Technology. Wiley-VCH Verlag GmbH, Weinheim ; New York. 
Shao, S., Liang, H., Qu, F., Yu, H., Li, K., Li, G., 2014. Fluorescent natural organic matter fraction s responsible for ultrafiltration membrane fouling: Identification by adsorption pretreatment coupled with parallel factor analysis of excitationemission matrices. Journal of Membrane Science 464, 33-42. https://doi.org/10.1016/j.memsci.2014.03.071

Shukla, S.K., Kumar, V., Van Doan, T., Yoo, K., Kim, Y., Park, J., 2015. Combining activated sludge process with membrane separation to obtain recyclable quality water from paper mill effluent. Clean Techn Environ Policy 17, 781-788. https://doi.org/10.1007/s10098-014-0836-2

Sousa, M.R.S., Lora-Garcia, J., López-Pérez, M.-F., 2018. Modelling approach to an ultrafiltration process for the removal of dissolved and colloidal substances from treated wastewater for reuse in recycled paper manufacturing. Journal of Water Process Engineering 21, 96-106. https://doi.org/10.1016/j.jwpe.2017.11.017

Sousa, M.R.S., Lora-García, J., López-Pérez, M.-F., Heran, M., 2020. Identification of Foulants on Polyethersulfone Membranes Used to Remove Colloids and Dissolved Matter from Paper Mill Treated Effluent. Water 12, 365. https://doi.org/10.3390/w12020365

Teychene, B., Collet, G., Gallard, H., 2016. Modeling of combined particles and naturalorganic matter fouling of ultrafiltration membrane. Journal Membrane Science 505, 185-193. https://doi.org/10.1016/j.memsci.2016.01.039

Tian, J., Yu, H., Shen, Y., Shi, W., Liu, D., Gao, S., Cui, F., 2015. Identification of irreversible UF membrane foulants by fluorescence excitation-emission matrix coupled with parallel factor analysis. Desalination and Water Treatment 57, 21794-21805. https://doi.org/10.1080/19443994.2015.1127783

Vela, M.C.V., Blanco, S.Á., García, J.L., Rodríguez, E.B., 2008. Analysis of membrane pore blocking models applied to the ultrafiltration of PEG. Separation and Purification Technology 62, 489-498. https://doi.org/10.1016/j.seppur.2008.02.028

Wang, Z., Wu, Z., Yin, X., Tian, L., 2008. Membrane fouling in a submerged membrane bioreactor (MBR) under sub-critical flux operation: Membrane 
foulant and gel layer characterization. Journal of Membrane Science 325, 238244. https://doi.org/10.1016/j.memsci.2008.07.035

Winter, J., Barbeau, B., Bérubé, P., 2017. Nanofiltration and Tight Ultrafiltration Membranes for Natural Organic Matter Removal-Contribution of Fouling and Concentration Polarization to Filtration Resistance. Membranes (Basel) 7. https://doi.org/10.3390/membranes7030034

Yu, J., Xiao, K., Xue, W., Shen, Y., Tan, J., Liang, S., Wang, Y., Huang, X., 2020. Excitation-emission matrix (EEM) fluorescence spectroscopy for characterization of organic matter in membrane bioreactors: Principles, methods and applications. Front. Environ. Sci. Eng. 14, 31. https://doi.org/10.1007/s11783-019-1210-8

Z. Wang, Z., Wu, Z., Tang, S., 2009. Characterization of dissolved organic matter in a submerged membrane bioreactor by using three-dimensional excitation and emission matrix fluorescence spectroscopy. Water Research 43, 1533-1540. https://doi.org/10.1016/j.watres.2008.12.033

Zaidi, A., Buisson, H., Sourirajan, S., Wood, H., 1992. Ultra- and Nano-Filtration in Advanced Effluent Treatment Schemes for Pollution Control in the Pulp and Paper Industry. Water Science and Technology 25, 263-276. https://doi.org/10.2166/wst.1992.0254

Zhu, X., Wang, Z., Wu, Z., 2011. Characterization of membrane foulants in a fullscale membrane bioreactor for supermarket wastewater treatment. Process Biochemistry 46, 1001-1009. https://doi.org/10.1016/j.procbio.2011.01.020 


\section{CHAPTER : CONCLUSIONS AND FUTURE WORK RECOMMENDATIONS}

Membrane separation technology especially ultrafiltration (UF) have gained popularity as a post-treatment to paper mill effluent due to higher effluent quality, low installation costs, simplify operation, smaller carbon footprints and ability to reduce contaminants to below prescribed limits.

However, one of the drawbacks of membrane separation is fouling which limits the wider-scale applications of the process in paper manufacturing applications (effluent treatment). Fouling is a complex phenomenon, causing as a main consequence a decrease in the permeate flux over time due to deposits of particles, colloids and dissolved substances (inorganics and organics) on the surface and/or in the pores of the membrane. Fouling in membrane increases operation and maintenance costs.

\subsection{Conclusions}

In this doctoral dissertation, membrane fouling on application of a UF system operated at constant pressure with PES membranes for the removal of dissolved and colloidal substances (DCS) from a paper mill treated effluent (PMTE) from a WWTP in a papermaking factory, has been demonstrated through 3 research steps involving effect of operating conditions on the average permeate flux, COD rejection rate and cumulative flux decline (SFD) (Step 1), fouling mechanisms and behavior (modeling) (Step 2), and Identification and characterization of membrane foulants (Step 3), respectively.

The effects and significance of TMP, CFV, temperature and MWCO on the average permeate flux $\left(\overline{J_{P}}\right)$, COD rejection rate and the cumulative flux decline (SFD), was investigated by robust experimental design. Analysis of the percentage contribution (P\%) indicated that the TMP and MWCO have the greatest contribution to the $\bar{J}_{P}$ (TMP $>\mathrm{MWCO}>\mathrm{T}>\mathrm{CFV}$ ) and SFD (MWCO > TMP > CFV > T). In the case of the COD rejection rate, the results showed that $\mathrm{MWCO}$ has the highest contribution followed by CFV $($ MWCO $>$ CFV $>$ T > TMP). 
The optimum conditions were found to be the second level of transmembrane pressure (2.0 bar), the third level of the cross-flow velocity $(1.041 \mathrm{~m} / \mathrm{s})$, the second level of the temperature $\left(15^{\circ} \mathrm{C}\right)$, and the third level of MWCO $(100 \mathrm{kDa})$. The validation experiments under optimum conditions achieved $\overline{J_{P}}$, COD rejection rate and SFD results of $81.15 \mathrm{~L} / \mathrm{m}^{2} / \mathrm{h}, 43.90 \%$ and 6.01 (around $28.96 \%$ average flux decline index $(\overline{F D}))$, respectively.

Additionally, field emission scanning electron microscopy (FESEM) images under optimum conditions showed that membrane fouling takes place at the highest rate in the first 30 minutes of UF.

The results demonstrate the validity of the approach of using Taguchi method and utility concept to obtain the optimal membrane conditions for the wastewater treatment using a reduced number of experiment. Therefore, this study could be used as a guideline for improve operating UF systems applied as a tertiary treatment for paperboard mill treated effluents under optimal conditions.

Once determined the best UF operating conditions, fouling behavior, especially on the effects of DCS on fouling mechanisms was evaluated using membrane fouling models.

Analysis of membrane pore blocking models adapted to crossflow ultrafiltration showed that the phenomenon controlling fouling, under most of the conditions tested, was intermediate and complete blocking $\left(R^{2}>0.96\right)$, followed by the gel layer formation model. It is represent that the colloidal matter is the main cause of the fouling as it forms a cake on the membrane. In addition, it was observed that the particle size distribution in the feed stream after the conventional filtration was between 1642 $158.9 \mathrm{~nm}$, which suggests the presence of dissolved material $(<220 \mathrm{~nm})$ responsible by precipitating on the membrane surface and becoming adsorbed within the membrane pore space.

In constant-pressure filtration, one of the reasons for a deviation between the theoretical model and the experimental can be explained by the necessity of experimental data such as particle size, cake concentration (volume fraction), filtration number, concentration and porosity of cake on the membrane surface, among other parameters, that are not always possible to measure easily and accurately. Whereas good measurements of these experimental parameters and components present in the 
PMTE would surely give a better fit between the experimental data and the theoretical model.

Measurements of particle size distribution and zeta potential near the isoelectric point, showed a substantial reduction in colloidal compounds. Additionally, given that COD was removed down to $110 \mathrm{mg} / \mathrm{L}$, it could be said that UF is suitable for producing water that can be reused in different papermaking processes.

The results of SUVA, FESEM - EDS, 3DEEM and ATR-FTIR analyses provided a better understanding of foulants characteristics. The 3DEEM results indicate that the dominant fluorescent substances on the fouled membranes were mainly associated with colloidal proteins (protein-like substances $\mathrm{I}+\mathrm{II}$ ) and macromolecular proteins present in the dissolved phase as soluble microbial by-product-like materials (SMPlike substances), whereas fluvic acid-like and humic acid-like substances were of lesser relevance.

In addition, polysaccharide (cellulosic species), fatty and resin acid substances were identified on the fouled membrane by the ATR-FTIR analysis and they play an important role in membrane fouling. In addition, the FESEM and EDS analyses indicate that the presence of inorganicfoulants on the membrane surfaces, such as multivalent metal ions and especially $\mathrm{Ca}^{2+}$ that could accelerate membrane fouling.

Therefore, it can be concluded thathydrophilic substances with large molecularweight, such as protein-like substances and polysaccharides, are mostly responsible for UF membrane fouling.

In summary, the research presented in this thesis was focused on understanding membrane fouling mechanisms through mathematical modelling and identify the chemical composition and possible origins of membrane foulants by 3DEEM and conventional technics, in order to improving the operation conditions via statistical DOE (Taguchi methodology) during the UF process applied to remove DCS on the PMTE.

\subsection{Recommendations and future work}

Based on the results presented in this thesis, the following future work is suggested:

1. Experimental determination of the input parameters of cake formation in constant-pressure model during UF process to remove colloids and dissolved 
matter from PMTE, including the cake porosity (void volume fraction) ( $\left.\varepsilon_{\text {cake }}\right)$ on the membrane surface, the mean particle diameter $\left(\mathrm{d}_{p}\right)$, cake concentration $\left(C_{\text {cake }}\right)$ and others characteristics of ther cake filtration as the shape of the colloids and total surface area of the particles per unit volume of cake (S), in order to better fit that kind of model.

2. Carry out experimental methods for splitting DCS taken from a PMTE in terms of size and hydrophobicity, in order to deepen understanding of membrane fouling mechanisms.

3. Investigate the phenomena of colloid aggregation after the UF process, since that some of the particle distribution in the permeate presents colloidal substances with a size greater than cut-off of the membrane.

4. Study membrane cleaning strategies (physical condition and chemical agents) to determine the optimal procedure for flux recovery, especially in the first 30 minutes of the process. Moreover, investigate pre-treatments to control membrane fouling in PES UF membranes (flat sheet) used to remove DCS come from paper mill secondary effluent. 


\section{Appendix A: Factorial Design Calculations}

\begin{tabular}{|c|c|c|c|c|c|c|c|c|c|c|c|c|c|c|c|c|c|c|c|c|}
\hline & C1 & C2 & C3 & C4 & C5 & C6 & $\mathrm{C} 7$ & C8 & C9 & C10 & C11 & $\mathrm{C} 12$ & $\mathrm{C} 13$ & C14 & C15 & C16 & C17 & $\mathrm{C} 18$ & C19 & C20 \\
\hline & $\begin{array}{l}\text { TMP } \\
\text { (bar) }\end{array}$ & $\begin{array}{l}\text { CFV } \\
(\mathrm{m} / \mathrm{s})\end{array}$ & $\begin{array}{c}\mathrm{T} \\
\left({ }^{\circ} \mathrm{C}\right)\end{array}$ & $\begin{array}{c}\text { Cut- } \\
\text { off } \\
(\mathrm{kDa})\end{array}$ & $\begin{array}{c}\mathrm{J} \\
\text { (L.m-2 h- } \\
\text { 1) }\end{array}$ & $\begin{array}{c}\text { DOC } \\
\text { (mg/L) }\end{array}$ & $\begin{array}{l}\text { fouling } \\
(m-1)\end{array}$ & SNRA1 & MEAN1 & PSNRA1 & PMEAN1 & SNRA2 & MEAN2 & PSNRA2 & PMEAN2 & SNRA3 & MEAN3 & PSNRA3 & PMEAN3 & nobs \\
\hline 1 & 1 & 0,46 & 15,0 & 10 & 18,10 & 56,25 & $1,26 \mathrm{E}+13$ & 25,16 & 18,10 & 44,44 & 149,29 & 35,00 & 56,25 & 37,04 & 69,81 & $-261,99$ & $1,26 \mathrm{E}+13$ & $-244,35$ & $1,65 \mathrm{E}+12$ & $-66,61$ \\
\hline 2 & 1 & 0,75 & 22,5 & 50 & 38,21 & 48,85 & $5,79 E+12$ & 31,64 & 38,21 & & & 33,78 & 48,85 & & & $-255,25$ & $5,79 \mathrm{E}+12$ & & & $-62,65$ \\
\hline 3 & 1 & 1,04 & 30,0 & 100 & 56,16 & 55,83 & $1,65 \mathrm{E}+12$ & 34,99 & 56,16 & & & 34,94 & 55,83 & & & $-244,35$ & $1,65 \mathrm{E}+12$ & & & $-57,57$ \\
\hline 4 & 2 & 0,46 & 22,5 & 100 & 107,94 & 46,92 & $6,06 \mathrm{E}+12$ & 40,66 & 107,94 & & & 33,43 & 46,92 & & & $-255,65$ & $6,06 \mathrm{E}+12$ & & & $-59,91$ \\
\hline & 2 & 0,75 & 30,0 & 10 & 50,44 & 60,42 & $1,02 E+13$ & 34,06 & 50,44 & & & 35,62 & 60,42 & & & $-260,14$ & $1,02 \mathrm{E}+13$ & & & $-62,86$ \\
\hline 6 & 2 & 1,04 & 15,0 & 50 & 96,51 & 57,69 & $5,45 \mathrm{E}+12$ & 39,69 & 96,51 & & & 35,22 & 57,69 & & & $-254,73$ & $5,45 \mathrm{E}+12$ & & & $-59,34$ \\
\hline 7 & 3 & 0,46 & 30,0 & 50 & 81,58 & 50,46 & $1,83 \mathrm{E}+13$ & 38,23 & 81,58 & & & 34,06 & 50,46 & & & $-265,26$ & $1,83 \mathrm{E}+13$ & & & $-63,68$ \\
\hline 8 & 3 & 0,75 & 15,0 & 100 & 159,52 & 53,75 & $4,84 \mathrm{E}+12$ & 44,06 & 159,52 & & & 34,61 & 53,75 & & & $-253,70$ & $4,84 \mathrm{E}+12$ & & & $-57,50$ \\
\hline 9 & 3 & 1,04 & 22,5 & 10 & 64,80 & 68,75 & $1,49 \mathrm{E}+13$ & 36,23 & 64,80 & & & 36,75 & 68,75 & & & $-263,45$ & $1,49 \mathrm{E}+13$ & & & $-62,86$ \\
\hline
\end{tabular}




\section{Main Effects Plot for Means}

\section{General Linear Model: J average 25 puntos versus TMP (bar); CFV (m/s); T ( $\left.{ }^{\circ} \mathrm{C}\right)$; Cut-off (kDa)}

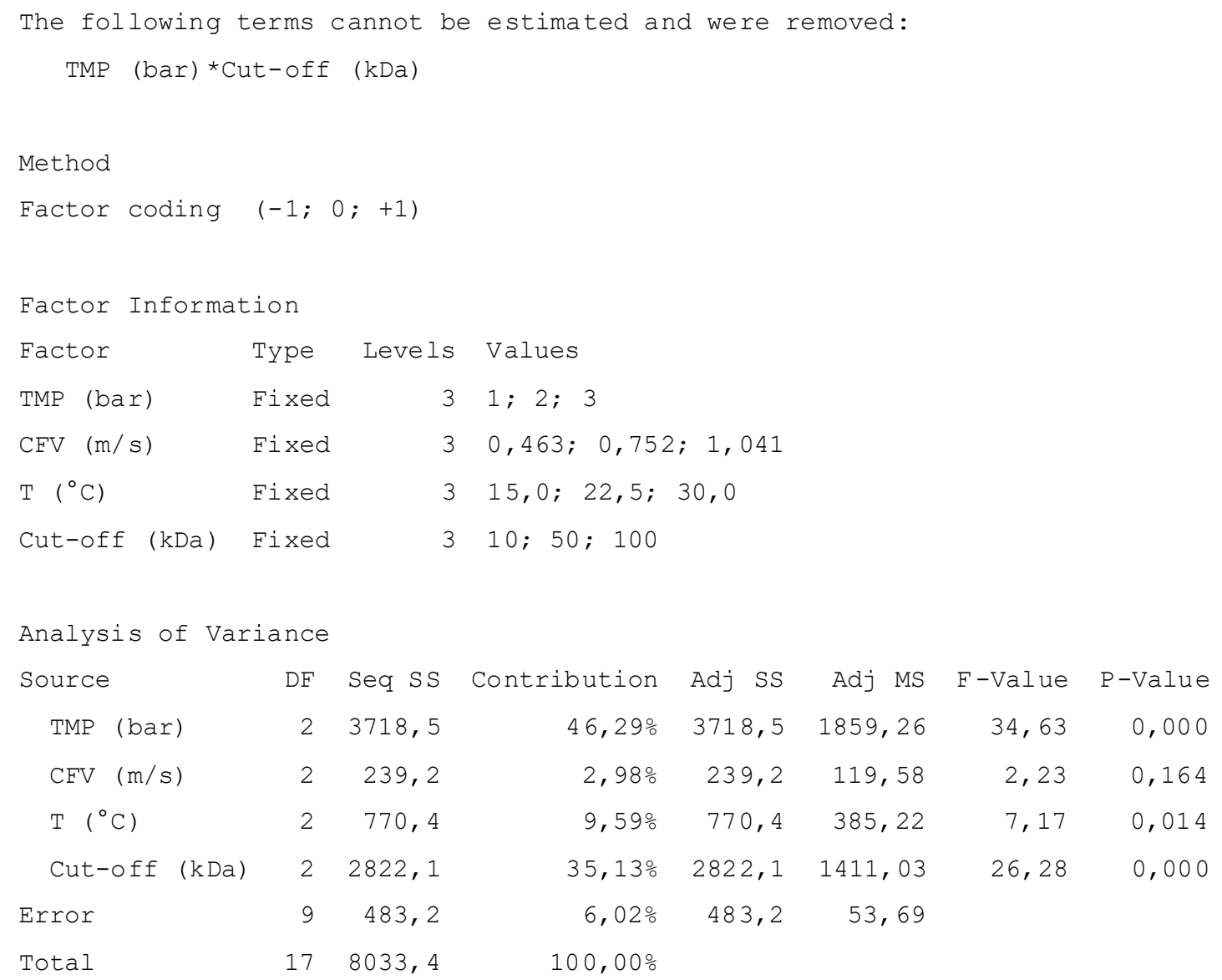


Taguchi Analysis: SNRA1 versus TMP (bar); CFV (m/s); T ( $\left.{ }^{\circ} \mathrm{C}\right)$; Cut-off (kDa)

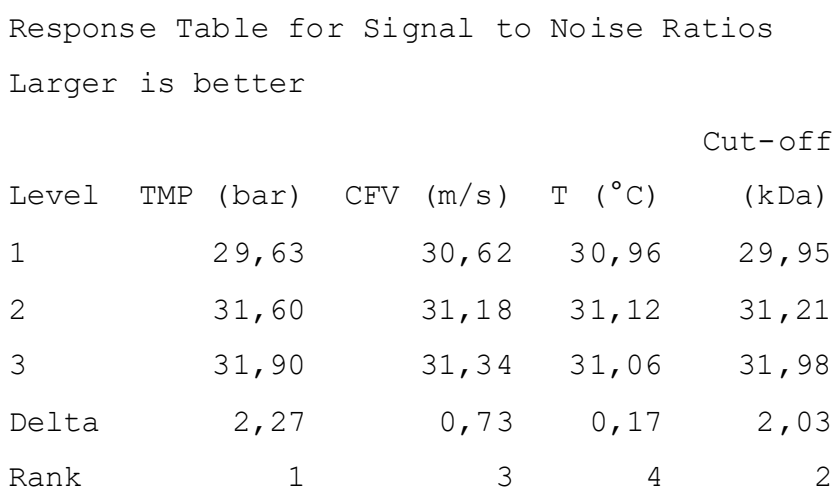

Response Table for Means

\begin{tabular}{|c|c|c|c|c|c|c|}
\hline Level & TMP & (bar) & $\mathrm{CFV}$ & $(\mathrm{m} / \mathrm{s})$ & $\mathrm{T} \quad\left({ }^{\circ} \mathrm{C}\right)$ & $(\mathrm{kDa})$ \\
\hline 1 & & 30,60 & & 34,68 & 36,30 & 31,81 \\
\hline 2 & & 38,14 & & 36,58 & 36,18 & 36,52 \\
\hline 3 & & 39,51 & & 36,97 & 35,76 & 39,90 \\
\hline Delta & & 8,91 & & 2,29 & 0,54 & 8,09 \\
\hline Rank & & 1 & & 3 & 4 & \\
\hline
\end{tabular}




\section{Appendix B: The Matlab modelling programmes.}

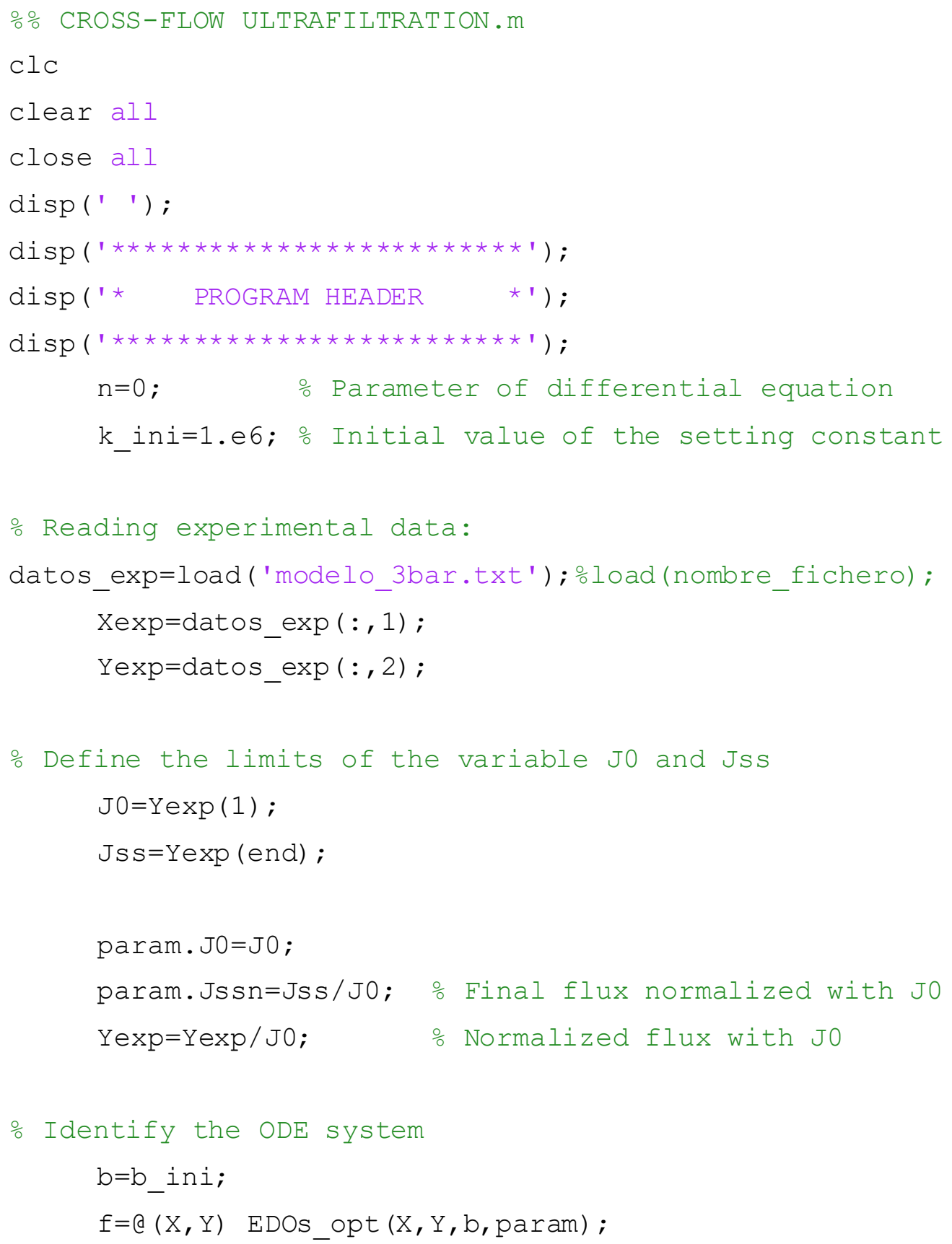


$[\mathrm{b}$, resnorm, residual, exitflag, output, l ambda, Jacobiano $]=l$ sqnon lin ( $\mathrm{g}$, b0 ,b_inf,b_sup, options);

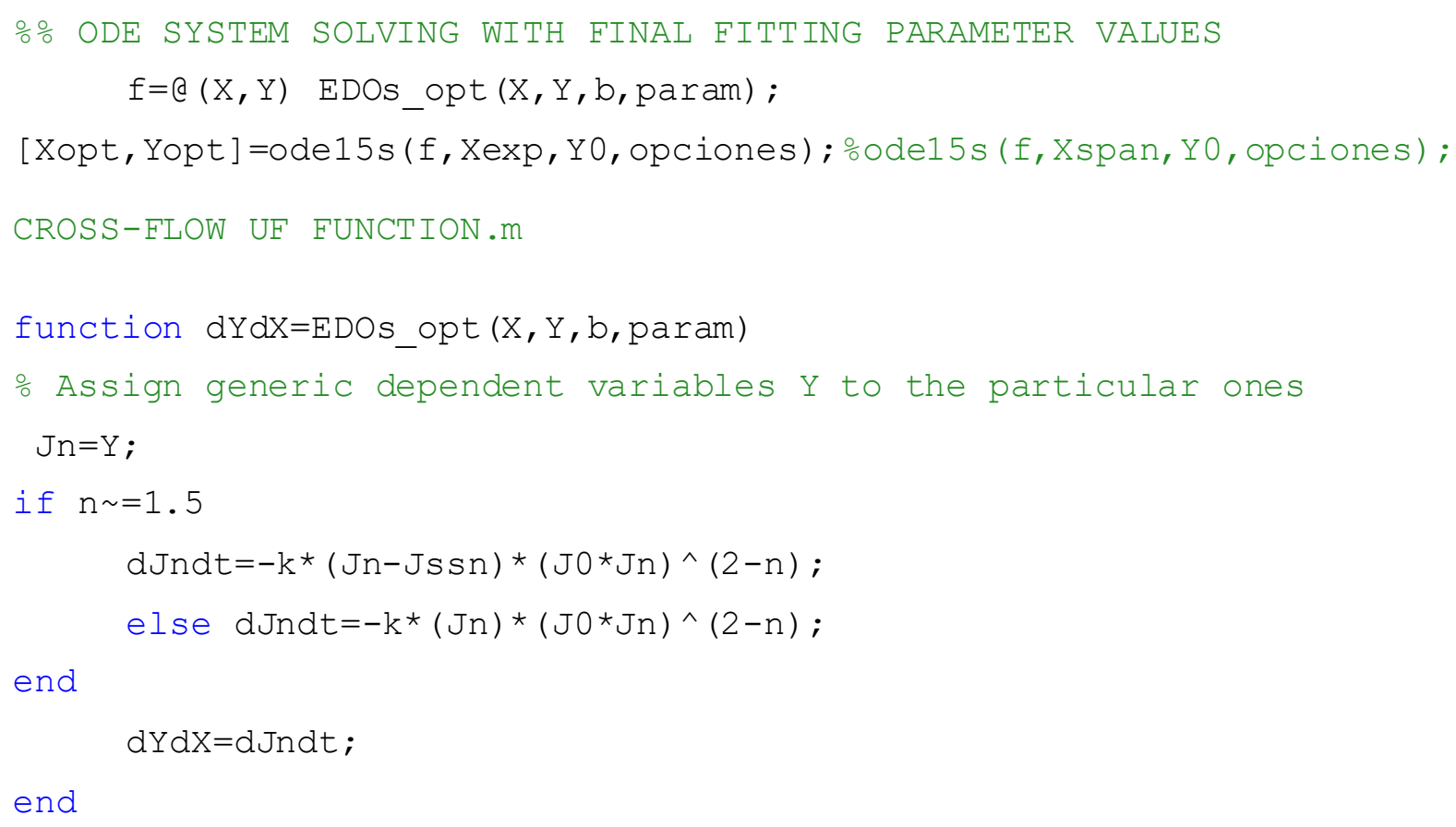

end

응 DEAD - END ULTRAFILTRATION.m

Variables

global Jo \% initialflux

Jo=datos_exp $(1,2)$;

global Jpss o steady stat flux

Jpss=datos_exp (end, 2$)$;

oInitial guess of the model constant and model fit

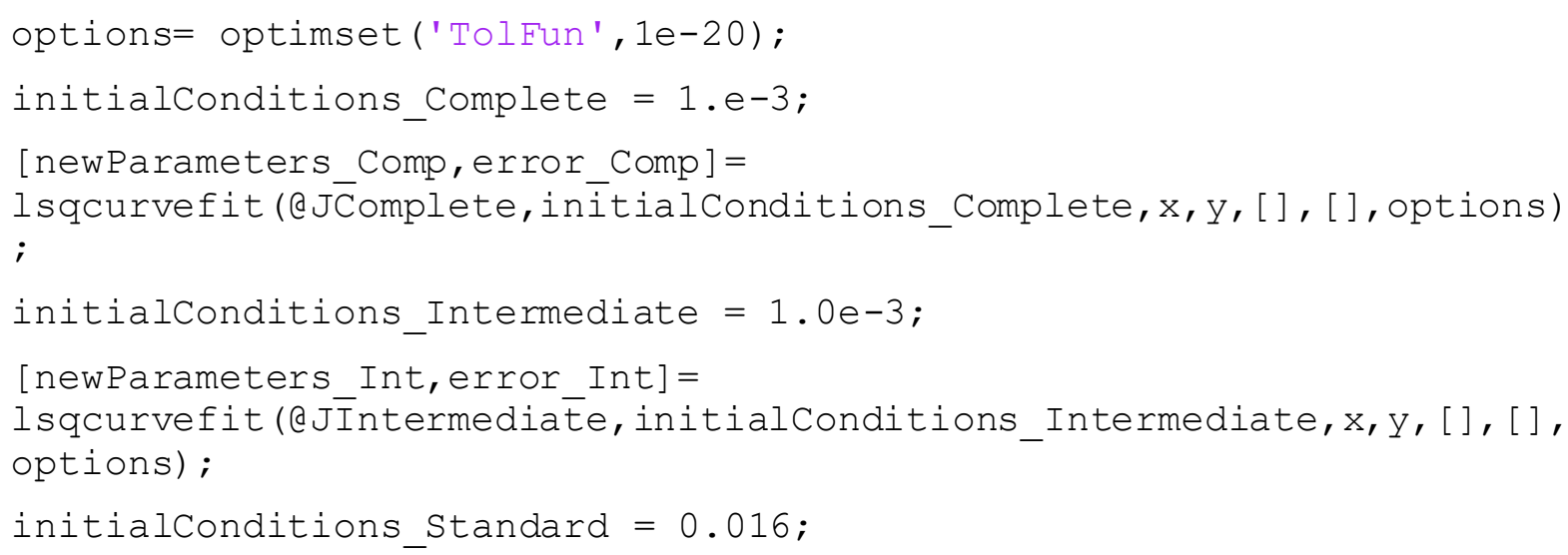




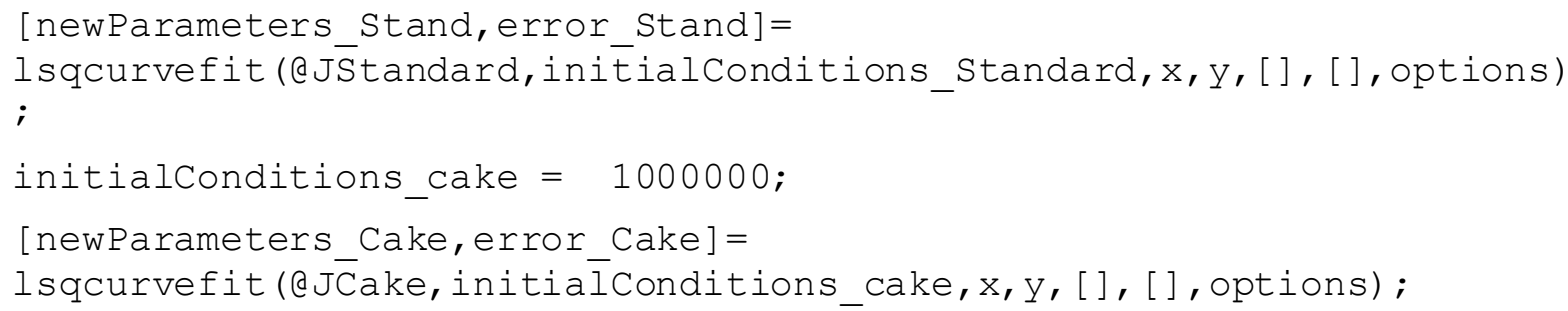

end

\% Function Intermediate blocking

function output= JIntermediate (param, input)

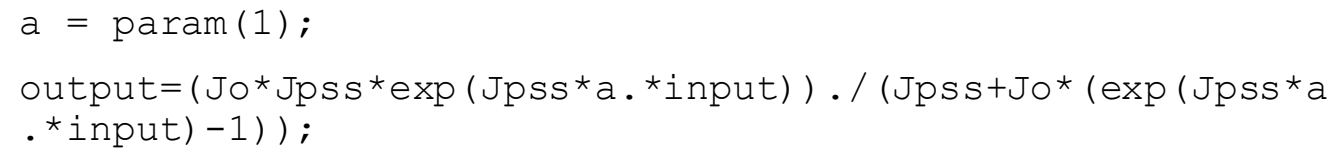

end

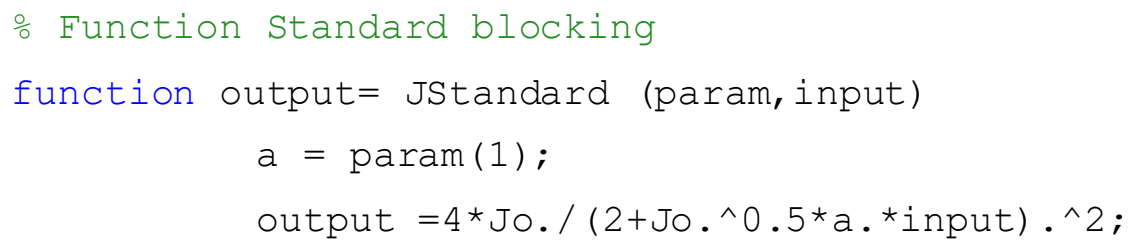

end

\% Function Cake filtration

function output= JCake (param, input)

a =param (1) ;

$\mathrm{b}=\operatorname{param}(2) * 1 e 6$;

alpha0=param (3);

$\mathrm{d}=\operatorname{param}(4)$;

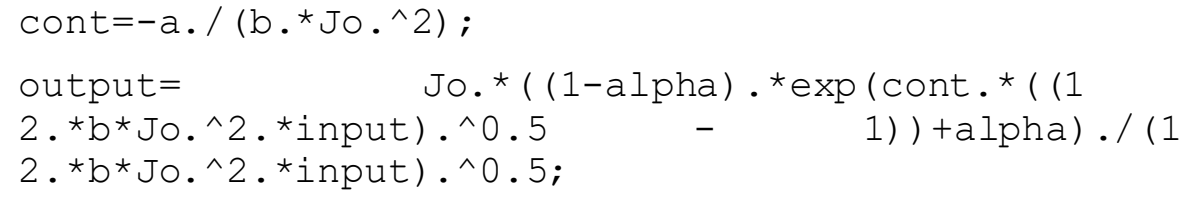

end 


\section{응 OPTIMIZATION PROCEDURE}

$\mathrm{y}^{2}$ _Comp = JComplete(newParameters_Comp, x); $\frac{\circ}{0}$ permeate flux fitted

$\mathrm{y}^{2}$ Int $=$ JIntermediate(newParameters_Int, $\left.\mathrm{x}\right) ;$ 응 permeate flux fitted

y2_Stand $=$ JStandard (newParameters_Stand, $\mathrm{x}) ; \quad \%$ permeate flux fitted

$y^{2} \_$Cake= JCake_rev (a_Cake,x,y);

- Suma de cuadrados sobre la media (SST)

Y_sum=sum $(y)$;

$\mathrm{n}=$ numel $(\mathrm{y})$;

yavg=y_sum $/ \mathrm{n}$;

degree of freedom $=\mathrm{n}-2$;

$\mathrm{df}=$ degree_of_freedom;

diff $2=y-y a v g$;

diff2_sq=(diff2) $\wedge^{\wedge} 2$;

$\mathrm{SST}=\mathrm{sum}(\mathrm{diff2}$ _sq

\section{응 Grafics}

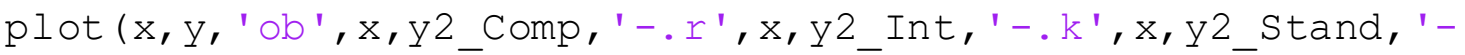
.m', $x, y^{2}$ Cake, ' -. $\left.g^{\top}\right)$

title('Blocking model fit')

xlabel ( $\{$ 'Time (s)' $\}$ )

ylabel ( $\{\mathrm{J}(\mathrm{m} / \mathrm{s}) '\})$

legend('Experimental permeate flux ','Complete blocking model ', 'Intermediate blocking model', 'Standard blocking

model', 'Cake formation model', 14, 'Location', 'NorthEast'); 